\title{
Um modelo conceitual para ambientes inteligentes baseado em interações formais em espaços físicos
}

\author{
Crhistian Alberto Noriega Guerra
}

TESE APRESENTADA

$\mathrm{AO}$

Instituto De Matemática e Estatística

DA

Universidade DE SÃo PAUlo

PARA

OBTENÇÃO DO TÍTULO

$\mathrm{DE}$

DOUTOR EM CIÊNCIAS

Programa: Ciência da Computação

Orientador: Prof. Dr. Flávio Soares Corrêa da Silva

Esse projeto é integrado ao projeto JamSession. Processo FAPESP: 2008/53977-3

São Paulo, agosto de 2012 


\section{Um modelo conceitual para ambientes inteligentes baseado em interações formais em espaços físicos}

Esta versão da tese contém as correções e alterações sugeridas pela Comissão Julgadora durante a defesa da versão original do trabalho, realizada em 22/11/2012. Uma cópia da versão original está disponível no Instituto de Matemática e Estatística da Universidade de São Paulo.

Comissão Julgadora:

- Prof. Dr. Flávio Soares Corrêa da Silva (orientador) - IME-USP

- Prof. Dr. Markus Endler - PUC-RIO

- Prof. Dr. Sérgio Takeo Kofuji - EP-USP

- Prof. Dr. José de Jesus Pérez-Alcázar - EACH-USP

- Prof ${ }^{\mathrm{a}}$. Dra ${ }^{\mathrm{a}}$. Anarosa Alves Franco Brandâo - EP-USP 


\section{Agradecimentos}

Agradeço a Deus por me dar forças para enfrentar todos os desafios que encontrei e por colocar no meu caminho as pessoas que me ajudaram a chegar onde estou.

Agradeço em especial ao meu orientador, o Professor Flávio, de quem ficarei sempre grato pela orientação acadêmica e pessoal durante estes anos. Apesar da formalidade de chamá-lo de Professor, o considero meu amigo. 


\section{Resumo}

Noriega G. Crhistian, Um modelo conceitual para ambientes inteligentes baseado em interações formais em espaços físicos. 2012. Tese Doutorado - Instituto de Matemática e Estatística, Universidade de São Paulo, São Paulo, 2012.

Neste trabalho apresentamos um modelo para ambientes inteligentes baseado em organizações de agentes, onde interações entre entidades são associadas a espaços físicos, pessoas carregam dispositivos e se movimentam entre diferentes espaços físicos e cada espaço físico contém definições de interações (comportamentos definidos por normas) próprias do seu contexto. São definidos três componentes deste modelo: (1) modelo conceitual, (2) linguagem de especificação e (3) ambiente de execução. A separação do modelo nestes três componentes traz como principais conseqüências: (1) a ativação de um ambiente inteligente é feita através de um mecanismo de alto nível, (2) a especificação de um ambiente inteligente é independente do domínio de aplicação e (3) as especificações podem ser executadas em mecanismos diferentes de execução.

Palavras-chave: ambientes inteligentes, sistemas multiagentes normativos, organizações de agentes, interações formais. 


\section{Abstract}

Noriega G. Crhistian, A conceptual model for smart environments based on formal interactions in physical spaces. 2012. Doctoral Thesis - Institute of Mathematics and Statistics, University of Sao Paulo, Sao Paulo, 2012.

We introduce a conceptual model for smart environments based on agent organizations where interactions between entities are associated with physical spaces, people (carrying mobile devices) move between different physical spaces and these physical spaces contain definitions of interactions (behaviors defined by norms) related to each context. This model defines three components: (1) conceptual model, (2) language specification, and (3) execution environment. The separation in these three components brings as main consequences: (1) activation of a smart environment is performed through a high-level mechanism, (2) specification of a smart environment is independent of the application domain, and (3) specifications can be performed on different mechanisms of execution.

Keywords: smart environments, normative multi-agent systems, agent organizations, formal interactions. 


\section{Sumário}

Lista de Figuras $\quad$ xi

Lista de Códigos $\quad$ xiv

1 Introdução $\quad \mathbf{1}$

1.1 Contribuições . . . . . . . . . . . . . . . . . . . . . . . . . . 3

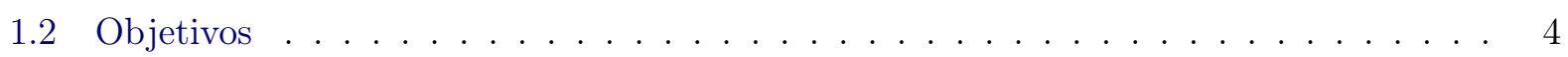

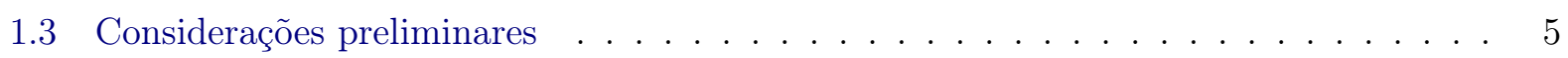

1.4 Organização do trabalho . . . . . . . . . . . . . . . . . . 5

$\begin{array}{lll}2 & \text { Estado da arte em Ambientes Inteligentes } & \mathbf{7}\end{array}$

2.1 Projetos em ambientes inteligentes . . . . . . . . . . . . . . 7

2.1.1 Experience Lab - Phillips . . . . . . . . . . . . . . . . . 8

2.1 .2 Fluid Interfaces $-\mathrm{MIT} \ldots \ldots \ldots \ldots \ldots$

2.1.3 Usable Smart Environments . . . . . . . . . . . . . . . . . . . . . . 11

2.1 .4 BlueSpace . . . . . . . . . . . . . . . . . . . . . . . . . 12

2.1.5 OSAmI - Open Source Ambient Intelligence . . . . . . . . . . . . . . . . 13

2.1.6 Projeto PERSONA - Perceptiva Spaces prOmoting iNdependent Aging . . . . 14

2.1 .7 Ambient Intelligence Research Lab . . . . . . . . . . . . . . . . . 15

2.1.8 Smart Environmet Group - SERG . . . . . . . . . . . . . . . . . 16

2.1 .9 Gator-Tech Smart House . . . . . . . . . . . . . . . . . . . . 18

2.2 Discussão geral dos projetos . . . . . . . . . . . . . . . . . . . . . . . 19

3 Ambientes Inteligentes como Organizações de Agentes $\quad 23$

3.1 Interações definidas por espaços físicos . . . . . . . . . . . . . . . . 23

3.2 Normas em sistemas multiagentes . . . . . . . . . . . . . . . . . . . . . 24

3.2.1 Organizações em sistemas multiagentes . . . . . . . . . . . . . . 25

3.2.2 Autonomia de agentes em organizações de agentes . . . . . . . . . . . . 26

3.3 Nossa definição de ambiente inteligente . . . . . . . . . . . . . . . . . . 27

3.4 Componentes do modelo para ambientes inteligentes . . . . . . . . . . . . . . . . 29

3.4.1 Instituições Eletrônicas como implementação de sistemas multiagentes normativos . . . . . . . . . . . . . . . . . . . . . . . 29

3.4.2 LCC como linguagem de especificação . . . . . . . . . . . . . . . . . . 29 
4 Componentes do Modelo para Ambientes Inteligentes

4.1 Modelo conceitual para ambientes inteligentes . . . . . . . . . . . . . . . 31

4.1 .1 Um exemplo preliminar . . . . . . . . . . . . . . . . . . . 31

4.1 .2 Fundamentos do modelo conceitual . . . . . . . . . . . . . . . . . . 33

4.1.3 Entidades do modelo conceitual e suas relações . . . . . . . . . . . . . . . . 33

4.1.4 Associação entre agentes e dispositivos . . . . . . . . . . . . . . . . 35

4.1.5 Ambientes inteligentes, espaços físicos e áreas simbólicas . . . . . . . . . . 36

4.1 .6 Informação de contexto . . . . . . . . . . . . . . . . . . 37

4.1 .7 Eventos nos mundos . . . . . . . . . . . . . . . . . . . . . 38

4.1 .8 Escopo de interação entre agentes . . . . . . . . . . . . . . . . . . . . 39

4.1 .9 Descoberta e execução de regras de interação . . . . . . . . . . . . . . . . 39

4.1 .10 Atores no projeto de um ambiente inteligente . . . . . . . . . . . . . 40

4.1 .11 Limitações do modelo conceitual . . . . . . . . . . . . . . . . . . . 41

4.2 Linguagem de especificação . . . . . . . . . . . . . . . . . . . . . . . . 42

4.2 .1 Fundamentos da linguagem de especificação . . . . . . . . . . . . . . . . . . 42

4.2 .2 Definição da linguagem de especificação . . . . . . . . . . . . . . . . . 42

4.2.3 Ontologia da linguagem e inferência de informação de contexto e eventos . . . 45

4.2.4 Definição de interações em LCC com informação de contexto . . . . . . . . . 46

4.3 Arquitetura do ambiente de execução . . . . . . . . . . . . . . . . . . . . 47

4.3 .1 Camada de infraestrutura . . . . . . . . . . . . . . . . 50 50

4.3 .2 Camada de serviços . . . . . . . . . . . . . . . . . 50

4.3 .3 Camada de entidades do modelo e agentes . . . . . . . . . . . . . 52

4.3.4 Camada de inteligência organizacional . . . . . . . . . . . . . . . . 52

4.3.5 Considerações na implementação do ambiente de execução . . . . . . . . . . . 53

5 Exemplos de uso $\quad 55$

5.1 Grupos de projetos focados em ambientes inteligentes . . . . . . . . . . . . . . 55

5.1.1 Grupo 1: Projetos focados no desenvolvimento de plataformas . . . . . . . . 55

5.1.2 Grupo 2: Projetos baseados em interações de entidades inteligentes . . . . . . 56

5.1 .3 Grupo 3: Projetos focados na percepção de humanos . . . . . . . . . . . . . 56

5.2 Caso de Estudo: Um ambiente inteligente para o IME . . . . . . . . . . . . . . . 56

5.3 Especificação e implementação do caso de estudo . . . . . . . . . . . . . . . . . . 59

5.3.1 Módulos do ambiente de execução e infraestrutura de comunicação .... . 59

5.3 .2 Localização de dispositivos . . . . . . . . . . . . . . . . . . 60

5.3.3 Definições declarativas de agentes e áreas simbólicas . . . . . . . . . . . . . 61

5.3 .4 Ontologia da linguagem para o caso de estudo . . . . . . . . . . . . . . 62

5.3.5 Processamento de mensagens e restrições na execução de regras de inter-ação 63

5.3.6 Implementação dos agentes do caso de estudo . . . . . . . . . . . . . . . . 64

5.3.7 Integração do modelo com Jason e o agente AmIIME . . . . . . . . . . . . . 70

5.4 Um modelo para ambientes inteligentes . . . . . . . . . . . . . . . . . 73

5.4.1 Características fundamentais de projetos em ambientes inteligentes . . . . . . 73

5.4.2 Grupo 1: Projetos focados no desenvolvimento de plataformas . . . . . . . . . 74

5.4.3 Grupo 2: Projetos baseados em interações de entidades inteligentes . . . . . . 75

5.4.4 Grupo 3: Projetos focados na percepção de humanos . . . . . . . . . . . . 76 


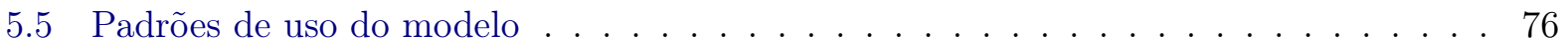

5.5.1 Interações como chamadas de métodos remotos contextualizadas . . . . . . 76

5.5.2 Interações iniciadas por localização . . . . . . . . . . . . . . . . 77

5.5.3 Papeis em interações como abstração de agentes . . . . . . . . . . . . 78

5.5.4 Agentes como abstração de dispositivos . . . . . . . . . . . . . . . 78

5.5.5 Pro-atividade no início de interações . . . . . . . . . . . . . . . . . . 79

5.5.6 Padrões de interações baseados em LCC e AgentSpeak . . . . . . . . . . . . . 80

6 Conclusões e Trabalhos Futuros $\quad 81$

6.1 Capacidades do modelo para ambientes inteligentes . . . . . . . . . . . . . 81

6.2 Trabalhos Futuros . . . . . . . . . . . . . . . . . . . . . 82

6.2 .1 Validação do modelo proposto . . . . . . . . . . . . . . . . . . 82

6.2.2 Um modelo para ambientes inteligentes baseado em mirror worlds . . . . . . 83

A API do ambiente de execução $\quad \mathbf{8 5}$

A.1 Classes e interfaces principais da API . . . . . . . . . . . . . . . 85

A.2 Criação de uma instância do ambiente de execução e um AgentBase . . . . . . . . . . 89

B Caso de Estudo: Um ambiente inteligente para o IME $\quad 93$

B.1 Áreas simbólicas do ambiente inteligente do IME . . . . . . . . . . . . . . . . . . 93

B.2 Ontologia da linguagem de especificação . . . . . . . . . . . . . . . . . . 95

B.3 Especificação do agente AmlIME . . . . . . . . . . . . . . . . . . . . . . 97

$\begin{array}{ll}\text { Referências Bibliográficas } & 101\end{array}$ 


\section{Lista de Figuras}

3.1 Nível organizacional e concreto em sistemas multiagentes. . . . . . . . . . . . . . 26

3.2 Sociedade semi-fechada: agentes dentro da organização são controlados por agentes externos (nível concreto). . . . . . . . . . . . . . . . 27

4.1 Exemplo de um ambiente inteligente como a interação entre um smartphone e uma câmera de vigilância. . . . . . . . . . . . . . . . . . . . . . . . 32

4.2 Ambientes inteligentes contém espaços físicos que por sua vez contém áreas simbólicas. 37

4.3 Descoberta de regras de interação. . . . . . . . . . . . . . . . . . . . . 40

4.4 Camadas do ambiente de execução. . . . . . . . . . . . . . . . . . . . . . . . 49

4.5 Serviços distribuídos entre instâncias do ambiente de execução. . . . . . . . . . . . . 51

5.1 Módulos do ambiente de execução. . . . . . . . . . . . . . . . . . . . . . 60

5.2 Interface Web do serviço SIMECalendar para cadastro de eventos públicos. . . . . . . 64

5.3 Interface do usuário do agente AmlCalendar para notificação de eventos públicos. . . . 65

5.4 Interface do usuário do agente AmICalendar para o registro e notificação de eventos

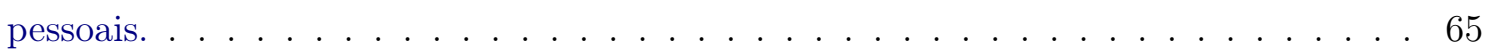

5.5 Interface de usuário do agente AmlLocator para consulta da localização de outros

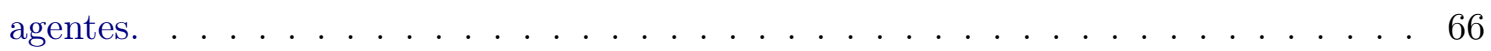

5.6 Tela de bem-vinda enviada pelo palestrante no auditório Gilioli. . . . . . . . . . . . 67

5.7 Interface do agente AmIFileShared para seleção e envio de arquivos. . . . . . . . . . . 68

5.8 Seleção do dispositivo adequado para visualização do arquivo. . . . . . . . . . . . . . 69

5.9 Impressão de arquivos na impressora definida na área simbólica das ETs (impressora

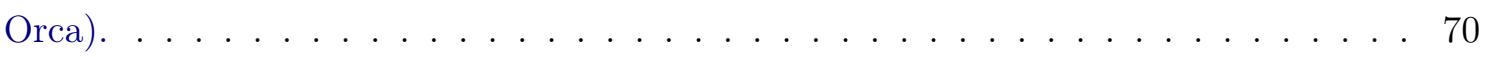

5.10 Execução do agente AmlIME dentro da console do Jason. . . . . . . . . . . . . . . . 72

5.11 Associação dinâmica Body-Agente . . . . . . . . . . . . . . . . . . . 75 


\section{Lista de Códigos}

4.1 Sintaxe da Linguagem de especificação. . . . . . . . . . . . . . . . . . . . . . 44

4.2 Principais entidades do modelo definidas na ontologia da linguagem. . . . . . . . . . 45

4.3 Exemplo de especificação de um ambiente inteligente como a interação entre um smartphone e uma câmera de vigilância. . . . . . . . . . . . . . . . . . 47

5.1 Interfaces de localização do ambiente de execução. . . . . . . . . . . . . . . . . 61

5.2 Definição de agentes do IME. . . . . . . . . . . . . . . . . . . . 61

5.3 Axioma para a definição de sub-áreas de áreas. . . . . . . . . . . . . . . . . . 62

5.4 Mapeamento entre objetos Java e conceitos F-Logic. . . . . . . . . . . . . . . . 63

5.5 Assinatura de métodos Java para chamadas de mensagens e restrições nas regras de interação. . . . . . . . . . . . . . . . . . . 6 . 63

5.6 Exemplo de regra de interação mapeada a métodos Java. . . . . . . . . . . . . . . . . 64

5.7 Declaração dos agentes AmlLocator no caso de uso . . . . . . . . . . . . . . 66

5.8 Regra de interação para o registro de agentes que entra na área simbólica blocoC . . 66

5.9 Regra de interação para consulta de localização de agentes. . . . . . . . . . . . . 67

5.10 Regra de interação do envio da apresentação do palestrante para um novo participante que acessa no auditório Gilioli. . . . . . . . . . . . . . . . . . . . 67

5.11 Regra de interação para o compartilhamento e processamento de arquivos através do agente AmlFileShared. . . . . . . . . . . . . . . . . . . . 68

5.12 Regra de interação para impressão de arquivos. . . . . . . . . . . . . . . . . . . 69

5.13 Regra de interação do agente AmIWelcome. . . . . . . . . . . . . . . . . . 70

5.14 Integração do modelo com AgentSpeak . . . . . . . . . . . . . . . . . 71

5.15 Modelagem de informação de contexto em smart homes. . . . . . . . . . . . . . . 74

5.16 Associação dinâmica Papel-Agente. . . . . . . . . . . . . . . . . . 76

5.17 Regra de interação que exemplifica uma chamada de método remota. . . . . . . . . 76

5.18 Interações baseadas em informação de contexto . . . . . . . . . . . . . . . 77

5.19 Interações baseadas em localização de áreas simbólicas. . . . . . . . . . . . . . . . 77

5.20 Adoção de papel segundo a informação de contexto do agente. . . . . . . . . . . . 78

5.21 Seleção de impressora por informação de contexto. . . . . . . . . . . . . . . . 78

5.22 Seleção de dispositivos na definição de interações. . . . . . . . . . . . . . . . . . . 79

5.23 Interação iniciada pelo agente no papel peerGreeter. . . . . . . . . . . . . . . . 79

5.24 Interação iniciada pelo agente no papel peerResponder. . . . . . . . . . . . . . . . 80

A.1 Interface Java do componente AmIModelCore. . . . . . . . . . . . . . . . . . . . . . . . . . . . . . . . . . . . .

A.2 Interface Java do componente AgentBase. . . . . . . . . . . . . . . . 86

A.3 Interface do listener para notificação de mensagens e restrições . . . . . . . . . . . 87

A.4 Classe abstrata do componente Body. . . . . . . . . . . . . . . . . . 87 
A.5 Exemplo de uso da API do ambiente de execução. . . . . . . . . . . . . . . . . . . . 89

B.1 Definição de áreas simbólicas do IME. . . . . . . . . . . . . . . . . . . . . . 93

B.2 Ontologia da linguagem de especificação. . . . . . . . . . . . . . . . . . . . . . 95

B.3 Comportamento do agente AmlIME em AgentSpeak . . . . . . . . . . . . . . . 97

B.4 Implementação da ação interna executeAsRole. . . . . . . . . . . . . . . . . . . . . . . 98

B.5 Criação de componentes AgentBase desde AgentSpeak. . . . . . . . . . . . . . . . . 99 


\section{Capítulo 1}

\section{Introdução}

Ambientes inteligentes oferecem diferentes desafios a várias áreas de pesquisa da ciência da computação, como a inteligência artificial (pois requerem mecanismos de coordenação dinâmicos entre entidades inteligentes [dSV07]), e a computação móvel (pois requerem mecanismos para suporte a pervasividade da computação e informação entre dispositivos móveis [RBB03]).

Um fator que torna relevante a pesquisa em ambientes inteligentes é o rápido avanço tecnológico na criação de dispositivos e aplicações que operam de maneira isolada e pretendem cobrir necessidades específicas, como smart-tvs, smartphones, assistentes pessoais com reconhecimento de voz e planejamento inteligente de atividades ${ }^{1}$ etc.

Existe a tendência de construir ambientes inteligentes em diferentes espaços físicos e com diferentes propósitos como bibliotecas, museus, campus de universidades, estações de metrô etc. [Nak09, JAL10]. Espaços físicos determinam ambientes inteligentes compostos por diferentes dispositivos e aplicações, que se encontram nestes espaços físicos e/ou são carregados pelas pessoas.

Um mesmo ambiente inteligente pode ser usado para diferentes propósitos [GHAH10]. Na atualidade existem poucos ambientes inteligentes funcionais implantados $\left[\mathrm{HMEZ}^{+} 05, \mathrm{FVDRGS}^{+} 10\right.$, per10], mas existe uma grande diversificação no domínio de aplicação destes ambientes. Por exemplo, no espaço físico de uma casa pode ser criado um ambiente inteligente para moradia assistida de pessoas com alguma doença, ou para ajuda a pessoas comuns no seu dia-a-dia. Ademais com o crescente desenvolvimento de entidades inteligentes (dispositivos e aplicações) não é possível prever como estas entidades podem interagir $\left[\mathrm{NSN}^{+} 02\right.$, Cis11]. Por exemplo, pode ser criado um smartphone através do qual seja possível controlar uma smart-tv.

Nas últimas duas décadas surgiram diversos projetos de pesquisa em ambientes inteligentes com diferentes visões e abordagens. A partir do estudo efetuado na dissertação de mestrado do autor do presente trabalho [Nor07, GS08], detectamos as seguintes funcionalidades necessárias para a construção de um ambiente inteligente:

1. Modelos computacionais para representação computacional do mundo físico do ambiente.

2. Desenvolvimento de arquiteturas de software e hardware para o suporte do modelo computacional.

3. Criação de tecnologias que permitem a ubiquidade da comunicação e computação.

4. Adaptabilidade do ambiente inteligente as necessidades de pessoas.

5. Interfaces inteligentes entre pessoas e dispositivos.

Estas funcionalidades podem ser decompostas nas seguintes características necessárias em um ambiente inteligente [DBS ${ }^{+}$01]: (1) ativação de hardware compatível, (2) plataformas abertas, (3) tecnologias intuitivas, (4) suporte ao desenvolvimento pessoal e organizacional e (5) segurança e tecnologias confiáveis.

\footnotetext{
${ }^{1}$ http://www.siri.com
} 
Os projetos existentes consideram, em geral, parte desses requisitos. O projeto Aura define a computação dirigida por tarefas [WG00], que propõe uma arquitetura que permite associar tarefas com serviços concretos no ambiente [SG02]. O projeto Gator-Tech define uma arquitetura que permite a escalabilidade do ambiente $\left[\mathrm{HMEZ}^{+} 05\right]$. O projeto Gaia define um ambiente de execução para agentes em um cenário de computação ubíqua $\left[\mathrm{RHC}^{+} 02\right]$ permitindo desenvolver um ambiente inteligente. Entre projetos mais recentes, o projeto OSAmI [FVDRGS $\left.{ }^{+} 10\right]$ fornece um modelo de programação e um arcabouço para a construção de entidades dentro de um ambiente inteligente seguindo o modelo SOA (Service-oriented Architecture). O grupo de pesquisa Fluid ${ }^{2}$ desenvolveu diversos dispositivos que servem como interfaces intuitivas com sistemas computacionais. O projeto PERSONA [per10] fornece um arquitetura e ambiente de execução especializados para a construção de ambientes inteligentes focados na assistência e monitoramento de pessoas com doenças degenerativas. No Capítulo 2 é apresentado um estudo mais detalhado destes e outros projetos.

Nestes projetos a construção de um ambiente inteligente é feita de maneira ad-hoc: a construção e ativação de um ambiente inteligente é feita segundo o domínio de aplicação, as tecnologias empregadas ou o arcabouço e arquitetura de suporte. Embora existam formalismos aplicáveis em ambientes inteligentes como o $\pi$-calculus ou ambient-calculus[GC03], nenhuma das implementações estudadas usa estas especificações de alto nível. Estes projetos adaptam métodos da inteligência artificial para conseguir implementar características relevantes no cenário de ambientes inteligentes, como planejamento em inteligência artificial ou modelos de sistemas multiagentes [PMR99, OZKT01].

A construção e ativação de um ambiente inteligente nestes projetos é dependente dos pontos listados a seguir.

modelo computacional: como no projeto Aura [SG02], que toma a computação dirigida por tarefas [WG00] como modelo para a definição da sua arquitetura e modelo de execução usadas para a ativação de um ambiente inteligente. Este modelo supõe uma entidade central encarregada de associar dinamicamente tarefas com recursos disponíveis no ambiente. Neste projeto, a arquitetura definida possui componentes que implementam especificamente a computação dirigida por tarefas o que faz necessário projetar um ambiente inteligente seguindo esse modelo de computação em mente. Nem todos os ambientes fornecem suporte segundo as tarefas das pessoas, como uma casa inteligente [TKA06] que oferece suporte segundo as preferências e metas das pessoas.

mecanismo de execução: como no projeto Gator-Tech $\left[\mathrm{HMEZ}^{+} 05\right]$ que conta com arquiteturas e ambientes de execução baseados na descoberta e composição de serviços. Todas as funcionalidades são fornecidas como serviços e o suporte às pessoas no ambiente se baseia no mecanismo de descoberta e composição inteligente de serviços. No projeto Gaia $\left[\mathrm{RHC}^{+} 02\right]$ é definido um sistema operacional para ativar ambientes responsivos sobre o qual são implementadas diversas funcionalidades do ambiente programaticamente. Nem todas as funcionalidades de um ambiente inteligente podem ser fornecidas como serviços. No caso do Gaia, nem todos os dispositivos possuem a capacidade computacional para executar as funcionalidades implementadas no sistema operacional.

tecnologias empregadas: como no projeto Oxygen [SM] que contém várias tecnologias úteis na implementação de um ambiente inteligente, como reconhecimento de voz e imagens, sistemas distribuídos de arquivos, redes de sensores, dispositivos especializados etc. Neste projeto a implementação de um ambiente inteligente se baseia na composição destas tecnologias e ferramentas, que foram construídas separadamente. Isto torna o ambiente dependente das tecnologias empregadas. O grupo de pesquisa Fluid também caracteriza um exemplo desta dependência. Outro caso é o projeto Gator-Tech que contém a uma casa inteligente com um chão de sensores para determinar a localização de pessoas. Embora este mecanismo possua grande precisão, não é aplicável em outro espaço físico como o campus de uma universidade.

\footnotetext{
${ }^{2}$ http://fluid.media.mit.edu/
} 
domínio de aplicação: como no projeto PERSONA [per10], cujo trabalho desenvolvido somente pode ser usado no domínio de monitoramento de pacientes com alguma doença degenerativa, e no projeto Smart Home [TKA06], que é focado no desenvolvimento de casas inteligentes fornecendo necessidades presentes exclusivamente neste cenário. Processos de reengenharia seriam necessários com o propósito de conseguir reutilizar esses mecanismos em outros domínios.

Estas dependências limitam as tendências apresentadas no inicio deste capítulo sobre diversidade de ambientes inteligentes e avanços tecnológicos de dispositivos e aplicações inteligentes. As dependências do mecanismo de execução, as tecnologias empregadas e o domínio de aplicação serviram de motivação para propor o modelo apresentado brevemente na próxima seção.

\subsection{Contribuições}

No presente trabalho, definimos um ambiente inteligente como uma organização de agentes em um espaço físico [Viz04]. Esta organização de agentes define as possíveis interações que podem acontecer entre agentes e que são próprias do espaço físico. Agentes implementam as funcionalidades do ambiente inteligente fazendo uso de tecnologias específicas. Agentes e dispositivos podem se deslocar livremente entre espaços físicos e interagem com outros agentes e dispositivos que se localizam em espaços físicos.

Uma organização de agentes é uma representação abstrata que define as relações esperadas e padrões de interação que deveriam acontecer entre agentes [DJ06]. Uma organização é definida como um conjunto de papéis com uma relação entre si, e um papel é um repositório para descrições de padrões de interação que um agente deve efetuar [Ver00]. Agentes adotam diferentes papéis definidos na organização com o propósito de interagir com outros agentes dentro da organização.

Apresentamos um modelo, baseado em nossa definição de ambiente inteligente, que ativa um ambiente inteligente a partir da especificação em uma linguagem de alto nível; a especificação de um ambiente inteligente é a descrição das interações que podem acontecer entre agentes que se encontram no espaço físico do ambiente e a ativação de um ambiente inteligente se refere a iniciar interações entre agentes, definidas na especificação do ambiente, a partir de mudanças na informação de contexto de agentes e dispositivos no ambiente.

O modelo é composto por três componentes:

modelo conceitual: define a ontologia de um ambiente inteligente: conceitos, dispositivos, agentes e suas relações. Define, também, o mecanismo para o inicio e execução de interações.

linguagem de especificação: define a sintaxe para a especificação de um ambiente inteligente: entidades, relações entre estas entidades e interações que acontecem entre elas.

ambiente de execução: permite a execução de especificações definidas na linguagem.

O modelo conceitual está baseado em nossa definição de ambiente inteligente. Assim, usamos Instituições Eletrônicas [Est03] como base para a implementação de uma organização de agentes. Instituições Eletrônicas fornecem um ambiente organizacional para sistemas multiagentes que permite a execução e cumprimento de normas e definem o comportamento das entidades (agentes e pessoas) através de protocolos de interação como speech acts [GC09]. Desta maneira, o modelo conceitual define um ambiente inteligente resumidamente como: um conjunto de papéis, regras de interação associados a espaços físicos e os mecanismos de descoberta e execução para o inicio de interações.

A linguagem de especificação está baseada no LCC [WR02] (Lightweight Coordination Calculus), que permite modelar interações entre agentes através de protocolos de interação no modelo de comunicação ponto-a-ponto. Também, foi extendido para especificar Instituições Eletrônicas, como é apresentado em [JdPBR $\left.{ }^{+} 07\right]$. Portanto, o LCC é adequado para adotar como base para especificar ambientes inteligentes segundo o modelo conceitual. 
Em $\left[\mathrm{RVD}^{+}\right.$05] e [WA09] é apresentado que informação de contexto de entidades (pessoas, dispositivos e aplicações) em um ambiente inteligente faz parte intrínseca do ambiente, desde que é informação implícita usada por dispositivos e aplicações do ambiente para fornecer funcionalidades relevantes a outras entidades do ambiente. Com este propósito, acrescentamos ao LCC a capacidade de modelar informação de contexto, necessária no cenário de ambientes inteligentes, desde que o LCC não permite: (1) definir o estado de contexto de um agente nas interações com outros agentes e (2) associar às mensagens de protocolos de interação o estado de contexto dos agentes envolvidos.

A definição de ambiente inteligente como organizações de agentes em espaços físicos e a extensão do LCC com informação de contexto oferece as seguintes vantagens:

- implementação livre de funcionalidades e sua adição no ambiente: agentes implementam funcionalidades específicas no ambiente usando diversas tecnologias. Estes agentes podem participar de interações dinamicamente segundo seu estado de contexto computacional e físico. Isto permite que a inteligencia, adaptação do ambiente e experiência do usuário de um ambiente inteligente sejam implementados com diversas tecnologias no modelo.

- especificações de ambientes inteligentes flexiveis e independentes do dominio de aplicação: o LCC possui uma poderosa sintaxe para definir protocolos de interação flexíveis no modelo de comunicação ponto-a-ponto.

- separação dos requerimentos tecnológicos da especificação do ambiente: especificações de ambientes podem ser executadas em ambientes de execução implementados com diferentes tecnologias, com o requerimento de conseguir processar especificações de ambientes.

Cumpre ressaltar, portanto, que este trabalho apresenta como principais contribuições o modelo conceitual apresentado e um ambiente de execução de especificações de ambientes inteligentes, mas não o suporte a uma implementação de um ambiente inteligente real que seja independente de especificações e implementações externas.

\subsection{Objetivos}

O objetivo geral deste trabalho é definir e implementar um modelo para ambientes inteligentes baseado em nossa definição de ambiente inteligente. Este modelo é composto pelos três componentes apresentados na seção anterior com o propósito de conseguir os seguintes objetivos específicos:

1. especificação de um ambiente inteligente feita através de um mecanismo de alto nível;

2. especificação de um ambiente inteligente independentemente do domínio de aplicação;

3. linguagem de especificação empregada como um mecanismo comum para a construção de dispositivos e agentes de um ambiente inteligente;

4. ambiente de execução construído empregando diferentes tecnologias, desde que permitam executar as especificações de ambientes.

Com o propósito de exemplificar o uso do modelo apresentamos um conjunto de padrões de uso do modelo que implementam características específicas de ambientes inteligentes propostas e desenvolvidas por outros projetos, e apresentamos como caso de estudo um ambiente inteligente que exemplifica o uso destes padrões em um cenário real. Este ambiente é especificado no espaço físico do IME (Instituto de Matemática e Estatística - USP) com o propósito de fornecer diferentes funcionalidades úteis. Este ambiente inteligente não foi colocado em funcionamento, e os experimentos se focaram nas interações entre agentes, em vez da construção de agentes que efetivem o funcionamento do ambiente. 


\subsection{Considerações preliminares}

Embora o ambiente de execução do modelo possua o suporte tecnológico necessário para a execução de especificações de ambientes inteligentes, o modelo não pretende ser um arcabouço para a construção de um ambiente inteligente, pois existem requisitos tecnológicos específicos para isso, além da ativação de interações entre agentes. Por exemplo, dois agentes que fazem parte de uma interação e transferem um arquivo através de uma tecnologia de comunicação particular (como Wi-Fi Direct) suportada pelos dispositivos em que estão hospedados exigiriam a especificação e implementação de serviços específicos adicionais.

O modelo considera que todas as funcionalidades no ambiente são implementadas por agentes e a construção destes agentes não é especificada pelo modelo. Não é feita nenhuma suposição sobre a arquitetura interna ou tecnologias envolvidas na construção de agentes. O único requisito sobre agentes é conseguir fazer parte de interações definidas no ambiente, ou seja, conseguir processar as mensagens definidas nas interações. Na Subseção 4.1.3 é feita a definição das entidades do modelo, incluindo a definição de regras de interação que definem interações como a troca de mensagens entre agentes. É importante notar que o modelo somente define as interações entre agentes e não a construção destes.

O modelo não pretende englobar todas as funcionalidades criadas por outros projetos para ambientes inteligentes. Novas funcionalidades podem ser incluídas no modelo através de novos agentes. Estas funcionalidades são fornecidas de diferentes maneiras, como interfaces humano-computador inovadoras, mecanismos de adaptação, dispositivos especializados etc.

Na Seção 4.3 é apresentado um protótipo do ambiente de execução do modelo e que fornece uma API (Application Programmable Interface) com o propósito principal de que agentes façam parte de interações com outros agentes de acordo com o modelo conceitual. Esta implementação foi usada no Capítulo 5 para exemplificar aspectos importantes do modelo.

Este trabalho não tem como propósito um estudo de sistemas multiagentes normativos, organizações de agentes e nem protocolos de interação em sistemas distribuídos. Adotamos as definições destes tópicos a partir da literatura revisada ou por proximidade com os pesquisadores destas definições. O objeto de estudo são ambientes inteligentes e estes tópicos são abordados porque são úteis para definir e implementar o modelo proposto.

\subsection{Organização do trabalho}

No Capítulo 2 é feito um estudo de projetos em ambientes inteligentes. São definidas cinco características principais na comparação destes projetos que são usadas para analisar o modelo desenvolvido. No Capítulo 3 é apresentada nossa definição de ambiente inteligente assim como os fundamentos que nos levaram a esta definição. No Capítulo 4 fazemos uma descrição detalhada dos componentes do modelo e apresentamos um exemplo preliminar. No Capítulo 5 apresentamos os experimentos e a implementação das principais propriedades do modelo. Também neste capítulo apresentamos os resultados obtidos e um conjunto de padrões de uso do modelo que demonstram as suas principais características. Finalmente, no Capítulo 6 expomos as conclusões obtidas e possíveis trabalhos futuros. 


\section{Capítulo 2}

\section{Estado da arte em Ambientes Inteligentes}

Nesta seção é feita uma análise de diversos projetos sobre ambientes inteligentes. Essa análise tem por finalidade: (1) estabelecer o estado de arte sobre metodologias, modelos e ferramentas para ambientes inteligentes e (2) definir e caracterizar um ambiente inteligente. Estes projetos foram selecionados porque cobrem uma quantidade abrangente de abordagens em ambientes inteligentes que existem na atualidade.

Com o propósito de sistematizar esta análise descrevemos as capacidades dos ambientes inteligentes criados por estes projetos com base nas seguintes características:

infraestrutura: suporte tecnológico a entidades do ambiente para comunicação, processamento e acessibilidade à informação;

interações: definição e suporte para interações relevantes entre entidades do ambiente inteligente;

sensibilidade ao contexto: coleta e processamento de informação de contexto (física, computacional etc.) sobre o estado das entidades do ambiente;

adaptação: capacidade do ambiente inteligente de se adaptar ao comportamento do usuário;

experiência do usuário: capacidade das pessoas interagirem com o ambiente de maneira transparente e natural; e

inteligência: esta característica pode estar coberta pela união de uma ou várias características anteriores. A avaliação de inteligência de um ambiente inteligente é uma tarefa subjetiva. Em alguns casos mencionamos, quando encontrado, o modelo de inteligência usado pelo projeto.

Estas características foram obtidas a partir de [DBS $\left.{ }^{+} 01\right]$ e [Nak09], que apresentam uma visão geral sobre abordagens e tecnologias existentes em ambientes inteligentes. Esses trabalhos também apresentam cenários onde ambientes inteligentes são de grande ajuda para pessoas e os requerimentos necessários para este objetivo.

\section{$2.1 \quad$ Projetos em ambientes inteligentes}

Organizamos esta seção segundo a capacidade do ambiente inteligente desenvolvido por cada grupo de pesquisa, desde um ambiente puramente reativo baseado nas percepções de pessoas, até plataformas complexas para uso em domínios específicos. 


\subsubsection{Experience Lab - Phillips}

Neste grupo de pesquisa foram desenvolvidas aplicações focadas na percepção de compradores em lojas de roupas. O ambiente muda de acordo com os produtos oferecidos na loja, com o propósito de influenciar as compras dos usuários, melhorando sua experiência.

Foram propostas as seguintes aplicações para esse tipo de ambiente:

Reactive Spotlight: foca iluminação sobre produtos específicos segundo o interesse dos compradores, centrando a atenção do comprador nos produtos. O sistema possui um sensor de proximidade que detecta quando uma pessoa se aproxima de um produto.

HaloShelf: muda a iluminação em torno de determinados espaços físicos de acordo com experiências anteriores dos usuários ou por configuração dos vendedores da loja. Com isto se reduz os custos de decoração da loja.

Attracting Shoplight: seguindo as idéias das duas aplicações anteriores, cria um jogo de luzes no ambiente.

Atmosphere Flipbook: altera a decoração (iluminação, imagens na parede etc.) de uma sala segundo um álbum de fotos.

Nestas três aplicações não é detalhado como é detectado o interesse de um cliente por um determinado produto, já que a proximidade física não é suficiente para considerar estes interesse. O ambiente inteligente criado por este projeto é puramente responsivo e afeta somente a percepção das pessoas que efetuam as compras. O ambiente é agradável para as pessoas efetuarem suas atividades, mas o ambiente não oferece nenhuma ajuda nestas atividades.

O objetivo destes projetos é permitir a usuários finais projetar, alterar e manter decorações personalizadas do ambiente para melhorar a experiência de pessoas. Assim, é introduzido o conceito de narrativa do ambiente (ambient narrative), que se refere aos ambientes que pessoas habitam representarem cenários onde as suas atividades são influenciadas pela decoração dos ambientes [vD09].

\section{Avaliação:}

infraestrutura: a infraestrutura fornecida é um conjunto de luzes de diferentes cores com capacidade de movimentação.

interações: a interação com pessoas (clientes da loja) é por proximidade a áreas físicas do ambiente ou por configuração estática dos vendedores.

sensibilidade ao contexto: é considerada a localização das pessoas para efetuar mudanças no ambiente; não é identificada a identidade da pessoa.

adaptação e experiência do usuário: o ambiente se adapta à experiência perceptiva das pessoas no ambiente através das luzes no ambiente.

inteligência: nenhum modelo de inteligência foi implementado neste projeto, que é puramente reativo e configurável.

\subsubsection{Fluid Interfaces - MIT}

Este grupo de pesquisa tem como visão geral criar novas interfaces entre humanos e computadores que ativem e permitam interações transparentes e relevantes. Foram desenvolvidos diversos projetos de pesquisa na linha de interações humano-computador (Human-Computer Interaction $\mathrm{HCI})$.

Os projetos deste grupo de pesquisa tem como foco os seguintes princípios: (1) melhorar as experiências das pessoas com informação digital existente no meio físico, (2) dotar a objetos físicos 
com a capacidade de responder a pessoas de maneira significativa e útil, (3) permitir interações entre múltiplos usuários ativando tarefas colaborativas e (4) acrescentar matéria prima com capacidades do mundo digital. Por exemplo, mostrar um video em uma folha de jornal de uma noticia relacionada. Assim, os três primeiros pontos se alinham com os requisitos de computação ubíqua e interações homem-computador necessários em um ambiente inteligente.

Entre os projetos mais representativos deste grupo de pesquisa destacamos:

TeleTouch: é um projeto na área de realidade mista onde a idéia principal é controlar objetos do mundo físico através da tela touchscreen de um smartphone ${ }^{1}$. Até o momento da escrita deste documento não foram encontrados suficientes detalhes técnicos sobre este projeto.

Augmented Product Counter - LuminAR: um projetor de imagens mostra informações dinâmicas sobre objetos em uma superfície; pessoas podem interagir com os objetos ou com as imagens projetadas, com o propósito de ativar aplicações de realidade aumentada. Outras abordagens deram origem à proposta deste projeto [LM10]. O avanço deste projeto está em dotar de um braço robótico o projetor e na capacidade de processar as interações das pessoas com as imagens.

No exemplo apresentado no site deste projeto se apresenta uma aplicação para a venda de câmeras fotográficas. Nesta aplicação, dependendo do modelo da câmera, são apresentados detalhes técnicos e comerciais sobre a câmera; pessoas podem clicar sobre estas imagens para conseguir maiores detalhes. A aplicação também permite assistência remota de outros vendedores ou técnicos que ajudam a esclarecer dúvidas dos compradores. Num exemplo mais elaborado é apresentado o caso em que são projetados vídeos relacionadas às noticias apresentadas sobre as folhas de um jornal.

O princípio deste projeto é empregado por outros projetos do grupo de pesquisa para conseguir interagir com informação no meio físico.

Sparsh: amplia o conceito de transferência de objetos digitais (imagens, texto, vídeos, aplicações etc.) entre aplicações (o típico "copiar e colar" dos sistemas de janelas) através de gestos entre diferentes dispositivos. Na idéia apresentada no projeto, objetos digitais são transferidos para o corpo do usuário através de um gesto (um toque na tela de um dispositivo) e transferidos a outro dispositivo através de outro gesto (outro toque na tela). A computação em nuvem fornece a infraestrutura para esta transferência, permitindo acessar esta informação através de qualquer dispositivo com a capacidade de se conectar com a nuvem [MM09a].

SixthSense [MM09b]: este projeto apresenta todo o potencial do uso da tecnologia desenvolvida pelo projeto LuminAR. O projetor e a câmera são montados num dispositivo portátil que pode ser carregado por uma pessoa, permitindo que a realidade aumentada e as interações aconteçam no ambiente físico e no contexto em que a pessoa se encontra (isto é, no espaço físico e nos objetos). A capacidade de movimentação permite obter esta interação em todo momento nas atividades de uma pessoa, o que dá a percepção de qualquer objeto físico no ambiente de uma pessoa poder se converter em um meio de interação com sistemas computacionais.

Nessa visão, diversas aplicações são apresentadas, desde documentos dotados com informação multimídia (vídeo e som) segundo seu conteúdo, até jogos interativos em trens do metrô ou projetadas sobre folhas de papel. Num exemplo prático deste projeto, é projetado sobre uma folha do mapa de metrô o caminho que poderia seguir uma pessoa até seu destino.

SixthSense ativa a presença de informação e interação com sistemas computacionais em qualquer lugar no cotidiano de uma pessoa, ativando um sexto sentido computacional nas atividades das pessoas.

MemTable: neste projeto foi criado uma mesa sensível ao toque que dá suporte ao projeto, desenvolvimento e gerenciamento de projetos de longo prazo que normalmente são feitos sobre

\footnotetext{
${ }^{1} \mathrm{http}: / /$ www.youtube.com/watch?v=YrtANPtnhyg
} 
mesas de desenho com base em anotações e técnicas de brainstorming. Esta mesa cobre pontos importantes no projeto de interfaces humano-computacionais, como manter o histórico de interações num período de tempo entre diversas pessoas. Assim, as principais funções da MemTable são [HMSK11]: (1) capturar e armazenar todas as interações e informações criadas numa reunião, (2) lembrar informações relevantes de interações anteriores na reunião corrente e (3) organizar e estabelecer associações entre informações coletadas em todas as reuniões.

O dispositivo criado neste projeto (a mesa) está dotado com algoritmos elaborados para o processamento da informação produzida pelos participantes. Este projeto mostra a possibilidade da construção de dispositivos altamente especializados para o suporte das atividades as pessoas num ambiente inteligente.

ReflectOns: este projeto tem como propósito criar objetos físicos no ambiente da pessoa que reflitam comportamentos das pessoas de maneira visível para estas, ativando uma melhor percepção dos comportamentos das pessoas. Exemplos deste objetos são: um pendrive que muda de peso físico segundo a quantidade de dados (em megabytes) armazenados nele; tomadas que mostram a quantidade de potência consumida pelos aparelhos conectados a ela; um cartão de crédito que mostra nele mesmo as compras efetuadas até o momento.

Estes projetos fornecem diferentes funcionalidades que podem ser aproveitados em um ambiente inteligente, já que ativam interações inteligentes entre humanos e sistemas computacionais. Mas, como foi apresentado no capítulo anterior, é necessário ativar interações inteligentes entre um conjunto de aplicações para ambientes inteligentes; isto é, todas as funcionalidades no ambiente inteligente devem estar integradas para que o ambiente reaja de maneira coerente às pessoas [Nor07].

\section{Avaliação:}

infraestrutura: a infraestrutura fornecida pela maioria de projetos é minima no referente a sistemas computacionais distribuídos e escaláveis. Pelo contrário, os projetos fornecem uma infraestrutura de hardware e software para aplicações pontuais e com um princípio tecnológico comum. Este é o caso do projeto SixthSense sobre o qual podem ser desenvolvidas outras aplicações que seguem o mesmo princípio.

interações: as pessoas percebem que estão interagindo com sistemas computacionais, mas estas interações podem acontecer em qualquer lugar e/ou com objetos presentes no dia-a-dia delas. Estas interações surgem de maneira natural no sentido de realidade aumentada e computação ubíqua.

sensibilidade ao contexto: os dispositivos desenvolvidos nestes projetos usam diversas informações de contexto, principalmente contexto computacional.

adaptação: pessoas conseguem se adaptar aos dispositivos desenvolvidos, que são objetos físicos dotados com certa tecnologia.

experiência do usuário: pessoas percebem que interagem com sistemas computacionais mas de uma maneira fácil, melhorando a usabilidade destes sistemas.

inteligência: nenhum modelo sofisticado de inteligência é detalhado na implementação dos projetos.

Uma particularidade na visão deste grupo de pesquisa é que os projetos não procuram interações transparentes entre pessoas e sistemas computacionais. Os projetos tentam melhorar esta interação facilitando a usabilidade e acessibilidade de sistemas e artefatos computacionais. Este princípio é contrário ao conceito da computação ubíqüa, mas pode ser perfeitamente aproveitado em um ambiente inteligente. 


\subsubsection{Usable Smart Environments}

Este grupo de pesquisa é mantido pelo laboratório FX Palo Alto ${ }^{2}$. A pesquisa deste grupo está baseada em sistemas e tecnologias para comunicação focados no suporte a atividades colaborativas. As principais áreas de pesquisa são as seguintes: (1) sistemas multimídia avançados, (2) interoperabilidade entre documentos, (3) espaços de realidade mista e (4) acesso a informação. Dentro destes, o ponto 3 é o de maior relevância para nosso estudo desta seção.

Nesta área foram desenvolvidas tecnologias que permitem interações entre pessoas distribuídas fisicamente através de mundos mistos que unem o mundo real, móvel e virtual. Nesta visão este grupo desenvolveu os seguintes projetos:

Virtual Factory [BKR ${ }^{+}$10]: um mundo virtual 3D que é uma réplica de uma fábrica de chocolate (mirror world). O mundo virtual é atualizado com informação em tempo real coletada por uma rede de sensores no ambiente físico. Este mundo virtual 3D foi projetado para simulação, virtualização e colaboração dos processos na fábrica, sincronizando o estado do mundo virtual com o mundo físico.

Uma vez que o mundo virtual é multi-usuário, é possível criar atividades colaborativas entre diferentes pessoas remotamente distribuídas, permitindo inspeções virtuais, treinamento de novo pessoal e monitoramento dos processos entre outras atividades, surgindo assim no mundo virtual um ambiente colaborativo.

Além disso, foi desenvolvida uma aplicação para dispositivos móveis que permite acessar informação do mundo virtual através do iPhone. Através desta aplicação é possível controlar certos equipamentos da fábrica e acompanhar os processos através de vídeos em tempo real.

Pantheia [RKV10]: é um sistema baseado em realidade aumentada que facilita a criação e manipulação de modelos baseados em imagens que representam espaços físicos (imagens situadas).

Na prática, são colocados sobre objetos físicos etiquetas que permitem automatizar a criação de modelos 3D. Cada uma destas etiquetas indica uma determinada forma do ambiente. Isto também tem o propósito de permitir rastrear objetos dentro do ambiente físico, os quais são atualizados no modelo.

Unit [TQB ${ }^{+}$10]: é uma plataforma para a criação de aplicações para ambientes de escritório que permitem efetuar tarefas colaborativas e situadas, empregando redes de sensores e mundos virtuais.

Este projeto propõe um nova visão de ambiente inteligente como a união de mundos virtuais e o mundo real. As publicações destes projetos somente descrevem as funcionalidades propostas mas não são detalhados os aspectos técnicos ou metodológicos na criação do ambiente. Isto faz acreditar que a implementação deste ambiente é $a d$ hoc, o que dificulta a escalabilidade de funcionalidades e entidades do ambiente.

\section{Avaliação:}

infraestrutura: o mundo virtual serve de plataforma para aplicações aproveitarem a rede de sensores do mundo físico e apresentar informações e processos de maneira imersiva para os usuários.

interações: o mundo virtual ativa interações entre pessoas distribuídas fisicamente e entre entidades virtuais e reais. Além disso, permite interações com objetos físicos através do mundo virtual, que são úteis para tarefas colaborativas.

sensibilidade ao contexto: a representação do mundo real no mundo virtual faz necessário ter informação de contexto em tempo real.

\footnotetext{
${ }^{2}$ http://www.fxpal.com
} 
adaptação: uma vez que se trata de um ambiente industrializado, é o ambiente que se adapta a configurações específicas dos usuários.

experiência do usuário: pessoas percebem que interagem com um mundo virtual criado por computadores, mas como o mundo virtual é uma réplica do mundo físico, as pessoas têm uma experiência imersiva dentro do mundo virtual.

inteligência: nenhum modelo sofisticado de inteligência é detalhado na implementação dos projetos.

\subsubsection{BlueSpace}

Este projeto é mantido pela IBM $^{3}$ e propõe uma plataforma para a integração de aplicações numa estação de trabalho baseadas em notificações, informação de contexto e adaptação do ambiente iniciado por situações (situation-triggered adjustments) [CGL $\left.{ }^{+} 01\right]$. Esta plataforma tem por objetivo melhorar a produtividade neste ambiente de trabalho, através de comunicações fluidas, trabalho colaborativo, interrupções não desejadas e adaptação personalizada do ambiente.

Foi desenvolvido um protótipo de uma estação de trabalho individual onde um pessoa desenvolve suas atividades. Esta estação é dotada de três telas touch-screen com objetivos específicos, sensores de ambiente, luzes sinalizadoras de atividades, um projetor capaz de mostrar imagens (e informação) sobre qualquer superfície da estação (chamado de ED-projector - Everywhere Display [Pin01]) e um sistema de ar condicionado pessoal.

As aplicações desenvolvidas sobre esta infraestrutura têm por objetivo ajudar nos seguintes pontos aos trabalhadores:

concentração: o display frontal da estação mostra o perfil, habilidades e projetos correntes em que a pessoa da estação vem trabalhando. Diferentes cores de luzes na parte superior indicam o estado de concentração do ocupante (ocupado - vermelho, verde - liberado e azul - ausente) a outras pessoas para facilitar a abordagem. Por exemplo, uma pessoa no estado ocupado recebe apenas mensagens urgentes projetadas na superfície da estação através do projetor $E D$.

colaboração: é possível iniciar atividades entre diferentes pessoas dependendo da sua disponibilidade. O meio de comunicação é autoconfigurado (e-mail, mensagens instantâneas, telefone etc.). O ED-projector permite que qualquer superfície dentro de uma estação se converta numa tela touch-screen, facilitando a interação entre grupos de pessoas através de gestos.

personalização: a estação pode autoconfigurar a luminescência e temperatura dependendo do perfil e atividades da pessoa. Os esquipamentos dentro da estação são facilmente mudados de posição, permitindo a comodidade da pessoa.

BlueSpace fornece uma infraestrutura para a implementação de diferentes aplicações com foco em uma estação de trabalho. A abordagem permite expandir a estações de trabalho com novas funcionalidades e interações sem afetar outras entidades ou aplicações já implementadas no ambiente. Nesta visão foi implementado um middleware que suporta as seguintes funcionalidades:

1. representação de contexto e estado baseada em especificações de documentos abertos, com o objetivo de conseguir interoperabilidade entre diferentes sistemas de informação corporativos: os documentos trocados nesta plataforma contêm: descrição de eventos de alto e baixo nível, descrição de gestos de pessoas, linhas de comandos, interações entre dispositivos e agentes dentro do ambiente, dentre outros;

2. publicação de informação: a plataforma permite o armazenamento e recuperação de informação de contexto através de um serviço distribuído. Esta informação é estruturada numa hierarquia que permite uma fácil discriminação e tratamento destas informações.

\footnotetext{
${ }^{3}$ http://www.research.ibm.com/bluespace/
} 
3. subscrição de eventos: entidades dentro do BlueSpace podem se subscrever por eventos e estados específicos de outras entidades. Este interesse é descrito em XPath (uma linguagem de consulta para banco de dados XML). Assim, uma entidade do ambiente pode monitorar mudanças de contexto e eventos de outras entidades.

4. gerenciamento de interações com o usuário: uma interação é um documento que indica a informação que o usuário deveria introduzir no sistema com o fim de ter uma resposta. Este documento é transformado no formato certo de acordo com o dispositivo que o usuário manipula.

\section{Avaliação:}

infraestrutura: fornece uma ótima infraestrutura para notificação e subscrição de eventos e estados entre as diferentes entidades do ambiente. Este modelo é estático sendo necessário que novas aplicações sejam desenvolvidas levando em consideração as capacidades da plataforma.

interações: interações são iniciadas por mudanças de contexto e eventos gerados por entidades no ambiente.

sensibilidade ao contexto: dependendo das capacidades dos sensores instalados no ambiente é possível coletar informação de contexto que pode ser usada por qualquer outra aplicação.

adaptação: dispositivos especializados podem mudar seus estados baseado em interações automáticas ou por configuração manual dos usuários.

experiência do usuário: usuários interagem com telas touch-screen, projetores, luzes etc., sendo perceptível a interação com sistemas computacionais. Estas interações sejam não intrusivas, pois os usuários têm que se concentrar em suas atividades e não no ambiente.

inteligência: cada entidade dentro do ambiente pode ser implementada com sua própria inteligência para interações com outras entidades e usuários. A infraestrutura somente oferece uma inteligência baseada em notificações e subscrições.

\subsubsection{OSAmI - Open Source Ambient Intelligence}

Fornece uma infraestrutura tecnológica abragante para a implementação de ambientes inteligentes. Esta infraestrutura é baseada na especificação OSGi (Open Services Gateway initiative), ativando o gerenciamento distribuído e remoto de componentes Java entre dispositivos móveis e fixos.

O grupo que desenvolveu este projeto considera um ambiente inteligente como um fornecedor de serviços automatizados embutidos nos dispositivos, sendo que qualquer dispositivo pode consumir ou fornecer serviços. Além disso, os serviços são auto-configurados segundo o contexto do dispositivo que fornece e/ou consome o serviço.

OSAmI estende OSGi com conceitos e princípios da Web Semântica através de OWL-S (Semantic Markup for Web Services) com o propósito de conseguir a descoberta e execução automática de serviços. Assim, foi desenvolvida a OWL-OS (OWL-OSGi Services Ontology) [FVDRGS ${ }^{+}$10] que estende a ontologia OWL-S para descrever serviços implementados em OSGi e foi alterado o serviço de registro de OSGi para conseguir a descoberta automática em base na descrição semântica dos serviços.

A infraestrutura fornece um mecanismo para o gerenciamento de contexto e preferências (CXMS - ConteXt Management System) necessário para a descoberta e execução de serviços. Este mecanismo é implementado como mais um serviço OSGi. As preferências no uso de serviços se baseia no histórico do uso dos serviços [VDRPA $\left.{ }^{+} 10\right]$.

Programaticamente a descoberta de serviços recebe como parâmetro a URI da ontologia em que está feita a descrição do serviço e uma consulta em SWRL que descreve o propósito do serviço requerido. 
OSAmI-D[LET ${ }^{+}$09] é um projeto que emprega o OSAmI para criar um ambiente para cuidado e monitoramento da saúde de pessoas. Este monitoramento pode ser feito ambulatorialmente ou no lugar em que as pessoas habitam. Foram criados serviços verticais que fornecem funcionalidades próprias ao cuidado da saúde, como análise cardíaca, geração de relatórios dietéticos etc. Serviços horizontais fornecem suporte ao acesso deste serviços através de diferentes fontes.

\section{Avaliação:}

infraestrutura: fornece uma infraestrutura baseada em serviços robusta e escalável que permite a descoberta e execução de serviços baseados na Web Semântica.

interações: a única interação descrita permitida por esta infraestrutura é através da chamada de métodos dos serviços, embora seja perfeitamente possível aplicar conceitos de planejamento em inteligência artificial para conseguir interações relevantes entre entidades do ambiente.

sensibilidade ao contexto: uma vez que a modelagem de contexto é feita empregando ontologias, é possível aproveitar raciocínio baseado em lógica descritiva para lidar com esta informação.

adaptação: a adaptação neste ambiente é em baixo nível, baseada na descoberta e execução de serviços. A infraestrutura mantém um histórico dos serviços executados anteriormente.

experiência do usuário: a infraestrutura se foca em baixo nível na implementação de um ambiente inteligente, portanto somente as aplicações desenvolvidas que usam esta infraestrutura estão em contato com os usuários.

inteligência: o uso de princípios da Web Semântica permite dotar a infraestrutura de modelos de inteligência mais elaborados, embora na literatura deste projeto não tenha sido encontrada nenhuma abordagem neste sentido.

\subsubsection{Projeto PERSONA - Perceptiva Spaces prOmoting iNdependent Aging}

Este projeto define como principal componente uma plataforma para execução de sistemas de moradia assistida (AAL - Ambient Assisted Living) [per10].

A plataforma aproveita conceitos de outras duas plataformas existentes com o mesmo propósito, SODAPOP [HK04] e Amigo [VRV05]. O primeiro fornece um middleware distribuído baseado em sistemas multi-agentes e ontologias, que define como conceitos principais barramentos (buses) e transdutores (transducers). Cada componente (dispositivo ou agente) dentro da arquitetura possui um transdutor que serve para se unir à arquitetura. Um barramento é um broker executado em cada componente da arquitetura que ativa a troca de mensagens entre vários transdutores. A plataforma Amigo, por sua vez, serviu para definir uma arquitetura baseada em serviços e a descoberta destes baseada em princípios da Web Semântica e SOA. Assim, para implementar uma funcionalidade dentro desta plataforma é desenvolvido um componente que disponibiliza suas funcionalidades como um serviço, usando tecnologias SOA ou OSGi, e uma descrição semântica em OWL-S.

Além disso, o PERSONA fornece varias camadas de abstração que vão desde controle de dispositivos físicos até a descrição semântica de serviços. Isto permite maior facilidade no uso da API para desenvolvedores. A plataforma define o conceito de chamada remota semântica de procedimentos (Semantic RPC - Semantic Remote Procedure Call) para ativar funcionalidades de ambientes inteligentes sem a necessidade de lidar com aspectos tecnológicos. Esta semântica na chamada de serviços junto com a contextualização dos componentes fornece inteligência ao sistema em geral.

Uma característica importante definida nesta plataforma são os tipos de barramentos definidos para troca de informação entre os componentes da plataforma: (1) de entrada, que contém informação de entradas capturado por dispositivos especializados ou interfaces com o usuário; (2) de saída, que fornece informação que deve ser publicada no ambiente (qualquer componente da plataforma consome estas informação); (3) de contexto: este barramento contém informação de contexto publicada por diversos componentes. Outros componentes consomem esta informação de contexto, 
particularmente este barramento é usado pelo barramento de serviços nas chamadas de serviços;

(4) de serviços, contêm descrições de serviços disponibilizados por componentes.

\section{Avaliação:}

infraestrutura: fornece uma plataforma robusta e escalável para o desenvolvimento e implantação de aplicações para ambientes inteligentes. A plataforma fornece recursos e serviços distribuídos entre componentes da plataforma e mantidos automaticamente. A plataforma permite que qualquer componente se torne um provedor e um consumidor de informação de serviços e informação de contexto.

interações: as interações entre componentes da plataforma é feita através de chamadas de serviços contextualizadas.

sensibilidade ao contexto: a plataforma fornece um mecanismo para coletar e compartilhar informação de contexto entre diversos componentes. Além disso, a plataforma integra de maneira automática a chamada de serviços com a informação de contexto.

adaptação: é mantido um histórico de contexto e serviços executados como método de adaptação entre componentes, mas está adaptação não é percebida pelas pessoas.

experiência do usuário: uma vez que pessoas estão em contato com aplicações desenvolvidas que rodam nesta plataforma, a experiência dos usuários se baseia nestas aplicações. Está experiência é ampliada acrescentada pelos recursos semânticos fornecidos pela plataforma.

inteligência: a inteligência nesta plataforma se baseia na capacidade de inferência sobre a descrição de serviços e estado de contexto.

\subsubsection{Ambient Intelligence Research Lab}

Este grupo de pesquisa da universidade Stanford ${ }^{4}$, define um ambiente inteligente (smart environmet) como um artefato de software que além de reagir às pessoas, aprende e adapta seu comportamento ao das pessoas. Este artefato também fornece interfaces intuitivas e não invasivas, comunicação e entrega de mensagens com o propósito de ativar aplicações de redes sociais. Para isto, é definido que a construção deste artefato se baseia nos seguintes pontos:

- processamento dirigido por contexto;

- projeto de aplicações centrado em pessoas;

- integração de visão com mecanismos de inferência de alto nível e

- aprendizado de máquina baseado em interações entre o ambiente e pessoas.

Baseado nestes conceitos, são definidos os seguintes domínios de aplicação para ambientes inteligentes:

bem-estar, saúde e comodidade: foram propostos e implementados métodos e aplicações para integrar informação de diversas fontes com o propósito de monitorar de maneira inteligente o comportamento de pessoas no ambiente. Em [WA09] se apresenta um modelo baseado em redes de Markov lógicas (Markov logic networks) para estabelecer relações entre objetos e contexto de pessoas no ambiente.

eficiência de energia e edifícios inteligentes: em [KWA10] é apresentado um modelo para predição inteligente do comportamento das pessoas para reduzir de maneira inteligente custos de energia em edifícios inteligentes.

\footnotetext{
${ }^{4}$ http://airlab.stanford.edu/
} 
ambientes multimídia: em [HAK08] se apresenta um mecanismo para a coleta e processamento de imagens a partir de uma rede de câmeras de vídeo, permitindo o acesso a mídia de maneira flexível e automática baseado em demanda ou em busca. O acesso é pervasivo com o propósito de pessoas interagir em transparentemente com o ambiente.

redes sociais pervasivas: é proposta a criação de espaços virtuais onde avatares podem refletir o estado de uma pessoa no mundo físico e interagir entre si. Através deste canal de comunicação é possível ativar interações entre pessoas de maneira mais imersiva que as existentes em redes sociais tradicionais [CUWA11].

aprendizado interativo: em [AKA09] é apresentado um método para aprendizado por reforço sem supervisão para processar e analisar o comportamento de várias pessoas que habitam o mesmo ambiente. Esse trabalho é apresentado como exemplo para o controle de musica e iluminação no ambiente.

As aplicações deste grupo de pesquisa se baseiam em técnicas de reconhecimento de imagens (através de redes de câmeras) integrados com bases de conhecimentos do ambiente. Esta base de conhecimento é composta por padrões de comportamento por regiões no ambiente. O conjunto das aplicações deste grupo de pesquisa se apresenta no projeto Prompting Interactive Mobile Engagement - PRIME [TKA06].

Este grupo de pesquisa propõe abordagens em diferentes áreas na construção de ambientes inteligentes, mas estas abordagens são isoladas entre si, criando diferentes domínios de aplicação onde foram desenvolvidas várias aplicações.

\section{Avaliação:}

infraestrutura: reconhecimento de imagens através de redes de câmeras e aprendizado computacional interativo através de interações e comportamentos de pessoas no ambiente.

interações: nenhum dos projetos define um mecanismo para interações entre entidades do ambiente. As interações surgem entre pessoas e dispositivos através da manipulação destes.

sensibilidade ao contexto: informação de contexto é embutida nos mecanismos de reconhecimento de imagens e aprendizado, sendo parte dos algoritmos em baixo nível.

adaptação: o aprendizado de maquina interativo permite que o ambiente se adapte ao comportamento das pessoas no ambiente.

experiência do usuário: as pessoas no ambiente têm contato com as aplicações desenvolvidas nestas plataformas e não com as infraestruturas implementadas.

inteligência: os mecanismos de aprendizado se encontram embutidos com algoritmos de baixo nível. Esta abordagem permite que o reconhecimento de imagens seja mais eficiente.

\subsubsection{Smart Environmet Group - SERG}

Este grupo de pequisa mantido pela universidade $U_{1 s t e r}{ }^{5}$, caracteriza um ambiente inteligente como o conjunto de tecnologias que fornecem suporte e monitoram pessoas no seu ambiente cotidiano (moradias). Os projetos deste grupo têm os seguintes temas: computação usável, computação autônoma, processamento e visualização de sinais vitais, análises de movimento e comportamento, e modelagem matemática.

O grupo possui vários projetos referentes a diferentes características de ambientes inteligentes no domínio de saúde e moradia assistida, que têm por objetivo melhorar a qualidade de vida de pessoas com doenças mentais. SemanticsAtHome [CN10] é um projeto já finalizado que propõe uma

\footnotetext{
${ }^{5}$ http://scm.ulster.ac.uk/ scmresearch/SERG/
} 
infraestrutura sensível a conteúdo semântico usando técnicas da Web Semântica e sistemas multiagentes para construir uma casa inteligente para cuidado da saúde. Nesta linha, foram desenvolvidos outros projetos como: CASCADAS [eRC08] que ativa serviços adaptáveis sensíveis ao contexto e a situação; CPVS[DNM ${ }^{+}$10] que ativa stream de videos em celulares para pacientes com Alzheimer; COGKNOW[cog] que lembra e monitora a pessoas com demência nas suas atividades diárias em casa e fora dela.

Entre os projetos mais destacados e ainda não finalizados se encontram:

BRAIN: [PLFN11] BCIs with Rapid Automated Interfaces for Nonexperts, que é um projeto iniciado pelo SERG e desenvolvido entre várias outras universidades da União Europeia. O objetivo deste projeto é fornecer ferramentas para o uso de Interfaces Cérebro-Computador (Brain-Computer Interface - BCI). Interfaces BCI permitem à pessoas deficientes interagir com o mundo físico minimizando a ajuda de outras pessoas.

BrainAble $^{6}$ é o projeto que usa e reflete melhor os objetivos do projeto BRAIN. BrainAble cria um espaço virtual 3D idêntico a um ambiente físico em que através de impulsos cerebrais, uma pessoa deficiente controla um avatar no mundo virtual, de forma que as ações no mundo virtual são refletidas no mundo real. Assim, pessoas deficientes conseguem interagir com o mundo físico. O mundo físico é implementado com princípios de ambientes inteligentes que facilitam a interação com o mundo físico.

SMART2: ${ }^{7}$ Self Management supported by Assistive, Rehabilitation and Telecare Technologies [Ros09], é um projeto desenvolvido entre várias universidades da União Europeia. Este projeto busca o uso de tecnológica para assistir a pessoas com doenças crônicas (doenças de longo período, inclusive o resto da vida). Através de tecnologias adequadas, o projeto possibilita entender as mudanças nas condições das pessoas e, com o conhecimento de especialistas, fornecer informação suficiente para entender seu estado e tomar medidas necessárias.

Um grande avanço deste grupo de pesquisa é o uso de interações cérebro-computador (Brain/Neuronal Computer Interaction (BNCI)) nos projetos propostos. Isto ativa um novo modelo de interação para aplicações em ambientes inteligentes.

Por outro lado, os artigos produzidos neste grupo de pesquisa estão relacionados a diferentes funcionalidades aplicáveis em ambientes inteligentes, mas são desenvolvidos de maneira isolada.

\section{Avaliação:}

infraestrutura: não é proposta nenhuma infraestrutura especializada e genérica em ambientes inteligentes. Cada projeto desenvolveu a própria segundo suas propostas e necessidades.

interações: são obtidas interações inovadoras entre o ambiente e as pessoas através de $B C I$.

sensibilidade ao contexto: nos projetos SMART2 e SmartAtHome é usada informação de contexto representada através de ontologias, o que ativa inferência automática.

adaptação: o objetivo principal do projeto SMART2 é conseguir alta adaptabilidade do ambiente com as pessoas em longos períodos de tempo. Isto é conseguido através de modelos lógicos e estatísticos.

experiência do usuário: novamente as BCI maximizam a experiência do usuário até o ponto de este achar que controla o ambiente com o pensamento.

inteligência: os modelos de inteligência na maioria dos projetos se baseia em inferência sobre ontologias.

\footnotetext{
${ }^{6}$ http://www.brainable.org/

${ }^{7}$ http://www.thesmartconsortium.org/Smart2
} 


\subsubsection{Gator-Tech Smart House}

Este projeto é mantido pela Universidade da Florida ${ }^{8}$ é está focado na pesquisa de computação pervasiva e móvel[HMEZ $\left.{ }^{+} 05\right]$. Este projeto segue uma abordagem de construir ambientes que fornecam assistência a pessoas em atividades repetitivas. Este projeto desenvolveu o hardware e software necessário para construir uma casa inteligente seguindo esta abordagem.

Este projeto implementa fundamentalmente o Atlas middleware baseado fundamentalmente em serviços que implementa todos os conceitos e abordagens propostos. Este middleware permite abstrair e desacoplar os aspectos tecnológicos se baseando em OSGi e DDL (Device Description Language), que é uma linguagem para a descrição de dispositivos. Esta visão permite mudanças altamente dinâmicas em serviços e dispositivos no ambiente.

São definidas três camadas na arquitetura do middleware: (1) camada física: que contém a descrição e implementação de diversos dispositivos (sensores, atuadores e dispositivos complexos), esta camada também fornece um mecanismo para obter refencias a estes dispositivos e ser facilmente localizados dentro do ambiente, (2) camada de serviços: contém serviços que representam dispositivos e serviços que implementam alguma funcionalidade. Nesta camada se encontram os mecanismos para a ativação do ambiente inteligente, são descritos os seguintes mecanismos: motos de processamento de consultas, gerenciador de deteção e rastreamento de eventos e gerenciador de sensores virtuais. Cada um destes componentes são focos de pesquisa dentro do projeto e (3) camada de aplicações: contém aplicações que consomem os serviços e mecanismos da camada de serviços, como principal componente é definido o compositor de serviços que permite compor serviços manualmente ou dinamicamente.

O middleware referente a computação pervasiva implementa os seguintes aspectos:

- integração de dispositivos e sensores: o projeto propõe integrar diferentes dispositivos através de um meio de comunicação que representa o espaço inteligente. Sendo que esta integração deve ser automaticamente escalável;

- espaços pervasivos programáveis: em vista da variabilidade de um ambiente inteligente o projeto propõe que a integração de dispositivos e serviços seja feito através de modelos de programação acessíveis por pessoas. Atualmente o projeto propõe um mecanismo baseado em Web semântica e planejamento em inteligência artificial para a composição de serviços.

- arqutieturas de sensores em nuvem: o projeto propõe acessibilidade de sensores do espaço físico através da Internet segundo os principios da computação em nuvem, isto com o objetivo fornecer a pervasividade da comunicação.

- aplicações e ativadores para computação pervasiva: o middleware fornece o suporte tecnológico necessário para a implementação de aplicações pervasivas. Para este propósito são fornecidos diferentes mecanismos e tecnologias como rastreamento de localização em espaços abertos e fechados.

No referente às características de computação móvel o middleware implementa as seguintes características.

- computação móvel baseado em redes ponto-a-ponto: foram implementados mecanimos para a descoberta de serviços baseada em informação de contexto onde fornecedores e consumidores de serviços são executados em pontos com capacidades computacionais suficientes.

- projeto, acesso e transações em bancos de dados móveis: ativa o acesso ubíquo de dados independentemente de dispositivos e aplicações no cenário de inestabilidade de conexões. Isto é feito através de algoritmos de concorrência e replicação eficientes.

\footnotetext{
${ }^{8}$ http://www.icta.ufl.edu/index.htm
} 
- redes móveis e colaboração móvel: através de dispositivos e redes móveis são ativadas interações colaborativas entre estes dispositivos para a execução de tarefas. Para isto o projeto fornece uma API para implementação de aplicações especializadas.

Este projeto construiu uma casa inteligente com diversos dispositivos inteligentes com o propósito de fornecer um ambiente assistido as pessoas que habitam esta casa. Com principais dispositivos construídos nesta casa podemos mencionar o smart floor que permite detertar a localização de pessoas dentro da casa a partir de sensores de pressão localizado no chão da casa, também permite detectar quedas de objetos para efetuar procedimentos de emergência. Smart bed é outro dispositivo não convencional que permite detectar padrões de sono de pessoas que dormem na cama para fornecer serviços e informações de maneira adequada.

\section{Avaliação:}

infraestrutura: o projeto fornece o middleware descrito anteriormente para gerenciar serviços fornecidos no ambiente inteligente.

interações: interaçoes são efetuadas através de composição de serviços, de maneira automática ou manual.

sensibilidade ao contexto: os mecanismos de descoberta e composição de serviços são efetuados baseados em informação de contexto de dispositivos e os próprios serviços.

adaptação: mecanimos de re-planejamento em inteligencia artificial podem ser facilmente aplicáveis em interações de serviços.

experiência do usuário: desde que aplicações especializadas são desenvolvidas sobre outras camadas do middleware, a experiência de usuários é baseado nas capacidades das aplicações desenvolvidas. O usuário não percebe diretamente os mecanimos baseados em serviços do middleware.

inteligência: esta característica é baseada na capacidade de implementação dos serviços e da composição dinâmica de serviços relevantes segundo informação de contexto.

\subsection{Discussão geral dos projetos}

Nesta seção apresentamos uma discussão geral sobre os projetos descritos. É feita uma comparação de cada projeto baseada nas características apresentadas no inicio deste capítulo, esta comparação mostra as características que um projeto satisfaz e as que não satisfaz. Isto tem como propósito estabelecer uma definição de um ambiente inteligente como a união destas características. Esta definição é um dos produtos principais do presente trabalho.

\section{infraestrutura:}

A implementação de um ambiente inteligente depende das capacidades tecnológicas que um ambiente inteligente deve alcançar. Portanto, a infraestrutura de um ambiente deve suportar, abstrair e facilitar a implementação e ativação destas funcionalidades. Assim, as infraestruturas dos projetos OSAmI, PERSONA, Gator-Tech e Amigo permitem que entidades externas forneçam estas funcionalidades.

Além disto, uma vez que o espaço físico de um ambiente inteligente é arbitrário [Nak09] (por exemplo, uma cidade, o campus de uma universidade, o sistema metropolitano de metrô, um prédio ou uma habitação) é necessário que a infraestrutura seja escalável sobre entidades (principalmente dispositivos) e funcionalidades do ambiente [KMTT03].

Os projetos OSAmI e PERSONA oferecem ótimas infraestruturas para aplicações em ambientes inteligentes, as quais são escaláveis e permitem a adição de (1) novas funcionalidades, dando 
suporte ao desenvolvimento de aplicações e (2) novas entidades, suporte a diversos dispositivos com diferentes tecnologias. A infraestrutura implementa funcionalidades próprias do modelo de ambiente inteligente ao qual dá suporte. Por exemplo, esse é o caso da infraestrutura do projeto PERSONA, que implementou barramentos especializados de comunicação baseados no modelo subscrição-notificação.

Os projetos ExperienceLab, do grupo SERG e Fluid não oferecem este tipo de arquitetura, dado que focam principalmente na implementação e melhoramento de funcionalidades específicas dentro de um ambiente.

\section{interações:}

Acreditamos que interações são elementos chave em qualquer ambiente inteligente, pois qualquer ação pode ser representada como a interação entre entidades do ambiente [DL95]. Portanto, interações entre entidades do ambiente inteligente devem ser dinâmicas e relevantes [WR02, ope].

Os projetos estudados fornecem dois tipos de interações: (1) interações humano-computacionais, através de interfaces especializadas não tradicionais; e (2) interações entre entidades do ambiente, através de uma infraestrutura adequada.

Como exemplo do primeiro tipo encontramos os projetos do grupo Fluid, o projeto BlueSpace e o projeto BrainAble. E como exemplos do segundo tipo encontramos os projetos OSAmI e PERSONA.

Consideramos que ambos tipos de interações são importantes em um ambiente inteligente, e que um tipo isolado não satisfaz esta característica do ambiente inteligente. Ou seja, dispositivos especializados como o ED-projector, MemTable ou SixthSense são úteis para interagir com pessoas de maneira intuitiva mas também existe a necessidade de interagir com outros dispositivos, especializados ou não, e para isto é necessária uma infraestrutura adequada. Por exemplo, os dados coletados pelo SixthSense podem ser apresentados no ED-projetor na estação de trabalho da pessoa, ou colocados dentro do MemTable no momento de uma reunião.

\section{sensibilidade ao contexto:}

Informação de contexto é importante, pois permite [WA09]: (1) descoberta automática de funcionalidades no ambiente; (2) entradas implícitas para a execução destas funcionalidades; e (3) representação computacional do estado físico das entidades do ambiente inteligente.

Todos os projetos coletam, processam e usam informação de contexto. Os projetos OSAmI, PERSONA e SmartAtHome representam informação de contexto através de ontologias na linguagem OWL (Web Ontology Language). Isto permite o uso de mecanismos da Web Semântica, como raciocínio automático, calçamento de ontologias, revisão de crenças etc. O projeto BlueSpace representa informação de contexto como arquivos XML, o que requer um tratamento ad hoc desta informação.

Neste ponto é importante considerar infraestruturas e mecanismos para coletar e fornecer informação de contexto de e para as entidades do ambiente [Nor07, Che04]. Por exemplo, o projeto PERSONA define um barramento dedicado na plataforma para a troca de informação de contexto de maneira separa da informação própria do domínio de aplicação. E o projeto OSAmI define um gerenciador de informação de contexto como um serviço da infraestrutura.

\section{adaptação:}

Segundo o princípio de ambientes inteligentes, o ambiente monitora pessoas no ambiente, e se adapta às condições, comportamento e preferências destas [KOA ${ }^{+} 99$, Gag05]. Os projetos BlueSpace e SMART2 conseguem esta adaptação em longos períodos de tempo. Neste caso, isto é requerido para o cuidado da saúde de pessoas com doenças crônicas.

Por outro lado, temos os projetos Reactive Spotlight e Atmosphere Flipbook da Phillips, que se adaptam à percepção que as pessoas têm do ambiente. 
No caso dos projetos do grupo Fluid são os sistemas computacionais que se adaptam da melhor maneira às condições (contexto físico) da pessoa. Esta adaptação é dos sistemas computacionais envolvidos, pois em todo momento pessoas percebem que interagem com tais sistemas através de objetos e cenários que fazem parte do seu dia-a-dia.

\section{experiência do usuário:}

Refere-se à experiência que as pessoas têm na interação com sistemas computacionais implementados dentro do ambiente. Neste ponto temos dois projetos com diferentes graus de experiência com o usuário. Os projetos do grupo Fluid possuem uma visão em que os sistemas computacionais são os que se adaptam para melhorar as experiências das pessoas na suas atividades cotidianas, mas estas pessoas percebem que interagem com sistemas computacionais, resultando numa experiência mais intuitiva. Já o projeto BrainAble permite que as pessoas controlem um avatar (a partir de impulsos cerebrais) no mundo virtual 3D que cria ações que mudam o mundo físico.

Há outros projetos focados em fornecer uma plataforma para a criação de aplicações dentro do ambiente. Este é o caso do projeto PRIME [TKA06], que facilita a construção de aplicações baseadas em visão computacional para melhorar a experiência do usuário no monitoramento de eventos no ambiente.

\section{inteligência:}

Consideramos que a inteligência do ambiente deve ser fornecida livremente e nenhum modelo deve restringir esta característica. Este é o caso do projeto PERSONA, que fornece mecanismos e um infraestrutura para fornecer informação relevante e adequada aos componentes que fazem parte do ambiente, sendo estes componentes que processam esta informação segundo o modelo de inteligência implementado.

Outros projetos implementam esta inteligência como parte da infraestrutura do ambiente, como o projeto OSAmI que emprega planejamento em inteligência artificial e inferência sobre ontologias para a descoberta e execução automática de procedimentos. Já os projetos do grupo SERG e o projeto SMART2 implementam modelos matemáticos e estatísticos.

No próximo capítulo mostramos como a definição de ambiente inteligente apresentada neste trabalho trata estas características. 


\section{Capítulo 3}

\section{Ambientes Inteligentes como Organizações de Agentes}

Neste capítulo apresentamos nossa definição de ambiente inteligente e os principais conceitos que nos levaram a esta definição.

\subsection{Interações definidas por espaços físicos}

Conforme apresentado em um estudo da Cisco [Cis11] sobre o crescimento de dispositivos móveis e tráfego de informação, atualmente a tendência é que toda pessoa carregue um ou vários tipos de dispositivos móveis consigo, como smartphones, tablets, telefones celulares, notebooks, PDA, consoles de vídeo jogos portáteis etc. com capacidade computacional cada vez maior para a execução de aplicações e comunicação. A mobilidade destes dispositivos permite que pessoas possam acessar e receber informação em qualquer lugar e em qualquer momento $\left[\mathrm{MYA}^{+} 05\right]$.

Em [Edm06] e [CUWA11] se apresentam teorias sociais que explicam o comportamento de pessoas associadas a espaços físicos. Em particular, é proposto que espaços sociais (grupos de indivíduos) são distribuídos em espaços físicos segundo as interações que existem entre indivíduos, além de fatores econômicos e ambientais. Por exemplo, o espaço físico de uma biblioteca é definido como o espaço para estantes de livros, um balcão para atendimento aos usuários, terminais de computador e mesas de leitura. Uma pessoa que entra neste espaço físico efetua diferentes operações e interações definidas no contexto da biblioteca, como buscar por livros de interesse nas estantes, consultar seu registro com os funcionários da biblioteca, consultar no sistema registros de livros, ler e consultar livros emprestados. Este mesmo cenário pode ser visto em outros contextos e domínios como aeroportos, museus, campus de universidades e estações de metrô.

Em $\left[\mathrm{RHC}^{+} 02\right]$ é apresentada a definição de espaço físico na visão da computação ubíqua. Espaços físicos são regiões geográficas com limites físicos bem definidos e podem conter objetos físicos, dispositivos heterogêneos e usuários que efetuam uma série de atividades. Um espaço físico pode ter associado um significado semântico que determina o tipo de entidades e serviços esperados no espaço físico. Por exemplo, uma cozinha e uma sala de estar são espaços físicos mas as atividades realizadas em cada um deles são diferentes. Também, um espaço físico possui uma localização geográfica e pode definir limites físicos dentro dele criando sub-espaços físicos contidos nele.

Espaços físicos podem cobrir regiões arbitrárias definidas no contexto de um domínio específico para um propósito específico. Por exemplo, estações de metrô espalhadas em diferentes lugares de uma cidade, tornando este espaço geograficamente disperso. Um espaço físico pode, também, conter sub-espaços, como o exemplo do campus de uma universidade dentro do qual existem sub-espaços como bibliotecas ou museus. Pode-se definir que pessoas que não estejam em nenhum sub-espaço pertencem ao espaço geral do campus da universidade.

Dentro de uma sociedade emergem comportamentos típicos que são aceitos e executados consensualmente pelos indivíduos da sociedade. Estes comportamentos podem ser especificados como normas da sociedade com diferentes níveis de obrigatoriedade [SA07]. Espaços físicos definem com- 
portamentos sociais determinados, ou seja, conjuntos de normas que definem as interações de indivíduos que se encontram dentro do mesmo espaço físico. As possíveis interações do grupo de indivíduos são definidas por normas e indivíduos que não obedecem estas normas recebem penalizações pelo seu comportamento inapropriado.

No exemplo da biblioteca, pessoas dentro do prédio (ou salas) da biblioteca se encontram com o propósito de procurar informação sobre temas que podem ser encontrados em livros, revistas, periódicos científicos ou interagindo com outras pessoas com os mesmos interesses. O fato que pessoas se encontrem neste espaço físico no contexto de uma biblioteca faz com que surjam essas necessidades [Nor07]. Como contra exemplo, uma pessoa não irá para um aeroporto em busca deste tipo de informação e interações, embora dentro do aeroporto possa existir uma loja de livros, a qual entretanto seria um sub-espaço dentro do espaço do aeroporto, que possui interações diferentes (embora similares) das encontradas na biblioteca.

Em particular no cenário de ambientes inteligentes notamos, a partir das observações anteriores, que pessoas podem se movimentar entre diversos espaços físicos no seu dia-a-dia, de forma que em um determinado momento estes espaços contenham um conjunto de dispositivos (e aplicações instaladas nos dispositivos) carregados por estas pessoas. Estas pessoas geram interações, através dos dispositivos e aplicações, com outras pessoas no contexto do espaço físico.

Neste cenário é necessário notar que espaços físicos não definem o estado interno destas entidades (pessoas, dispositivos e aplicações), mas sim as suas interações. Cada entidade tem a decisão de fazer parte das interações e processar estas interações. Do ponto de vista computacional, é importante notar que são os dispositivos e aplicações que efetivamente implementam processos computacionais. Outra importante observação sobre esta abordagem é que, diante da variedade possível de espaços físicos, é necessário ter um mecanismo que permita às entidades se adaptar dinamicamente às interações que são definidas pelas normas do espaço físico, sem a necessidade de conhecer antecipadamente o espaço físico e suas possíveis interações. Assim, é necessária uma padronização na definição de normas para diferentes espaços físicos e domínios. Por outro lado, não todos os espaços físicos definem interações, mas para construir um ambiente inteligente em um espaço físico, estas interações devem poder ser definidas.

\subsection{Normas em sistemas multiagentes}

A visão de sistemas multiagentes através das ciências sociais tem motivado a união de sistemas normativos e sistemas multiagentes, criando sistemas multiagentes normativos, em que sistemas multiagentes têm incorporado conceitos e modelos sobre o comportamento de seres humanos propostos por teorias sociais [CUWA11]. Um modelo popular de sistema multiagentes normativo define um conjunto de agentes cujas interações são governadas por normas [BvdTV06], sendo que estas normas descrevem o comportamento ideal dos agentes e o comportamento não permitido para os agentes.

A definição de interações em sistemas multiagentes pode ser muito complexa, mesmo em sistemas com algum mecanismo de coordenação, como linguagens ACL (Agent Coordination Language) [OZKT01], pois fatores próprios de um agente como autonomia, proatividade e busca de metas individuais fazem com que o comportamento de um agente seja imprevisível. Este ponto é ainda mais crítico quando se trata de um sistema multiagente aberto, onde agentes são construídos independentemente com diferentes modelos de inteligência, autonomia e coordenação [ST92]. Assim, é pouco provável que agentes criados por diferentes projetistas possam interagir sem nenhum problema. Para isto, é necessário fazer algumas suposições sobre a comunicação e arquitetura dos agentes. Como apresentado em [DL95], e mesmo fazendo este tipo de suposições, é difícil que agentes adotem estes padrões de maneira universal, como foi proposto nas linguagens FIPA ACL ${ }^{1}$ e KQML ${ }^{2}$.

Assim, é apresentado em [Ver00] que a coordenação e interação entre agentes totalmente desconhecidos um do outro seria impossível sem o uso de normas que ativem a coordenação, interação

\footnotetext{
${ }^{1}$ Agent Communication Language (ACL) proposto pela Foundation for Intelligent Physical Agents

${ }^{2}$ Knowledge Query and Manipulation Language
} 
e organização entre agentes. Um sistema multiagentes aberto sem normas pode trazer comportamentos inesperados ou maliciosos no sistema como um todo. No caso de agentes cujas ações são totalmente guiadas pelas suas metas particulares, agentes completamente egoístas podem ocupar recursos desnecessariamente sem liberá-los para outros agentes, e agentes maliciosos podem tentar afetar o funcionamento de outros agentes, alterando o ambiente em que estão sendo executados.

Um bom exemplo que ajuda a demonstrar este ponto são as regras de trânsito. Pessoas dirigindo seu veículo -agentes autônomos- numa cidade têm a meta de chegar a seu destino. Sem a existência das regras de trânsito - normas- esta tarefa levaria ao caos. As preferências nos cruzamentos, faixas dedicadas, semáforos, horários de estacionamento etc. definem o que é permitido às pessoas e seus veículos fazer ou não fazer; o pré-acordo destas normas pelas pessoas facilita o cumprimento das metas de cada agente. Obviamente, estas normas podem não ser cumpridas, o que traz penalidades a seus infratores de acordo com o problema causado no sistema como um todo.

Este trabalho não tem como objetivo fazer um estudo sobre sistemas multiagentes normativos. Em lugar disto, adotamos os conceitos sobre organizações de agentes e tipos de sociedades de agentes apresentado em [DJ06] e [FGM03], respectivamente. Como é apresentando a seguir, a separação de organizações de agentes de sistemas multiagentes permite explicar nossa definição de ambiente inteligente com relação a sistemas multiagentes.

\subsubsection{Organizações em sistemas multiagentes}

Em [GC09] é apresentado um modelo para a definição e cumprimento de normas através de organizações de agentes. Também em [FGM03] é apresentada uma organização de agentes como um conjunto de papéis com alguma relação entre si, que fazem parte de interações sistemáticas (repetitivas e reusáveis), padronizadas (resultado de definições aceitas comumente) e institucionalizadas (aceitas por todos os membros) com outros papéis. O papel de um agente é a descrição do comportamento abstrato de um agente e descreve obrigações, requisitos e habilidades (restrições) que um agente deve satisfazer e os benefícios de cumpri-lo. Em outra visão, um papel é um repositório para descrições de padrões de interação que um agente deve efetuar [Ver00].

Em [FGM03] é apresentada uma abordagem onde sistemas multiagentes podem co-existir com organizações de agentes. Nesta abordagem são apresentados dois níveis de interação: (1) nível baseado em agentes -nível concreto- e (2) nível baseado em organizações -nível organizacional ou social. O nível concreto corresponde à abordagem tradicional em sistemas multiagentes baseados em estados de agentes de maneira individual, relações entre eles e como estas relações influenciam o comportamento do sistema.

Como apresentado em [JSW98], sistemas multiagentes abertos (nível concreto) possuem as seguintes principais desvantagens: (1) as interações entre os agentes e o resultado destas é imprevisível e (2) prever o comportamento do sistema como um todo baseado no comportamento dos agentes é difícil, se não impossível, em decorrência da alta possibilidade de termos comportamento emergente, por vezes indesejável. O nível organizacional supera estas desvantagens através da definição de organizações. Uma organização tem as seguintes principais características:

1. agentes que apresentam um comportamento específico;

2. comportamentos de agentes estão relacionados com o comportamento geral da organização através de papéis dentro da organização;

3. agentes são comprometidos com padrões de comportamentos e

4. tipos de comportamento são definidos como relações entre papéis, tarefas e protocolos.

O nível organizacional é uma representação abstrata do nível concreto, que define as relações esperadas e padrões de interação que deveriam acontecer entre agentes no nível concreto e, portanto, as restrições e benefícios no comportamento dos agentes. Organizações fornecem uma nova maneira para descrever estruturas e interações que acontecem entre agentes. O nível organizacional está caracterizado por: 
1. fornecer uma estrutura organizacional de interação entre agentes;

2. fornecer especificações (através de algum tipo de normas ou regras) dos limites e expectativas no comportamento dos agentes e

3. não fornecer descrição do estado interno dos agentes, nem informação sobre metas, crenças, intenções etc. dos agentes.

A Figura 3.1 mostra estes dois níveis onde agentes no nível concreto adotam papéis definidos no nível organizacional. Interações no nível concreto acontecem arbitrariamente entre agentes sobre alguma infraestrutura comum. Interações no nível organizacional são definidas como relações entre papéis.

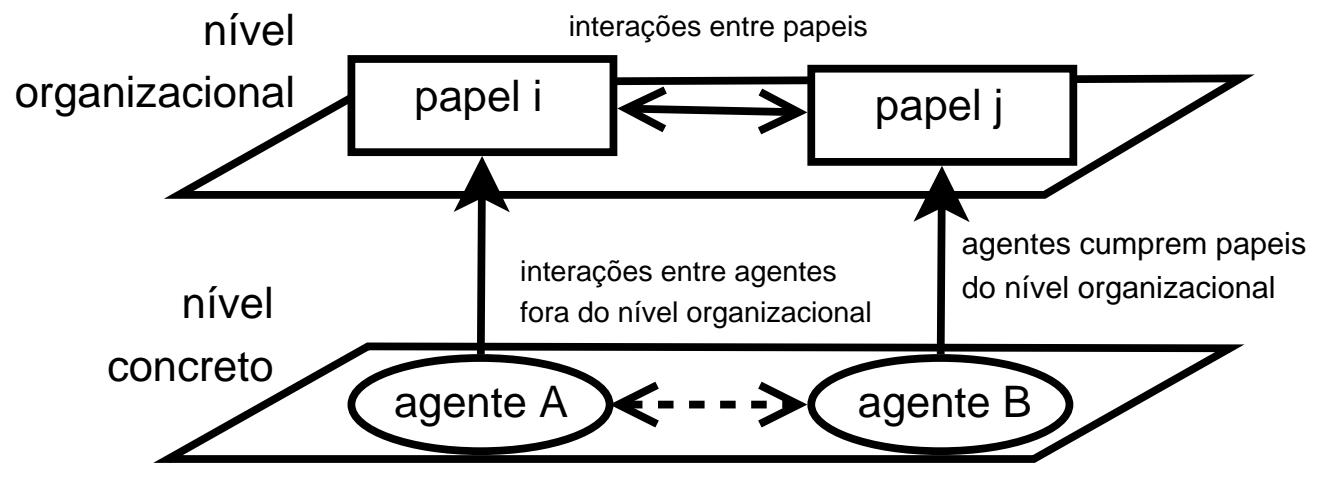

Figura 3.1: Nivel organizacional e concreto em sistemas multiagentes.

\subsubsection{Autonomia de agentes em organizações de agentes}

Uma discussão importante referente a organizações de agentes é o equilíbrio adequado entre os agentes aceitarem fazer parte de uma organização e a própria autonomia dos agentes. Em [DJ06] são apresentados quatro tipos de organizações baseadas em quem criou o agente e como um agente consegue ser parte da sociedade. Estes tipos são:

sociedades abertas: agentes não têm restrições para interagir com outros agentes ou para fazer parte da sociedade. Geralmente os agentes desta sociedade são criados com modelos de percepção, processamento e ação diferentes e por diferentes projetistas. Neste tipo de sociedade a única estrutura é uma linguagem de baixo nível aceita por todos os agentes.

sociedades fechadas: existe um proprietário da sociedade que foi o encarregado de projetar a sociedade com uma finalidade específica, por isto agentes são explicitamente projetados para cooperativamente alcançar uma meta. Nesta sociedade se tem absoluto controle de todas as possíveis interações entre os agentes.

sociedades semi-abertas: é uma sociedade aberta onde um agente precisa se identificar numa entidade central para fazer parte da sociedade. Esta entidade central avalia se o agente consegue cumprir as restrições da sociedade. Após avaliação o agente consegue interagir com outros agentes livremente.

sociedades semi-fechadas: são sociedades fechadas onde agentes externos interagem dentro da sociedade somente através de um agente criado dentro da sociedade que representa o agente externo. Agentes externos controlam o agente interno, que é limitado pelas restrições da sociedade. A Figura 3.2 apresenta estas idéias nos níveis organizacional e concreto apresentados na seção anterior. 


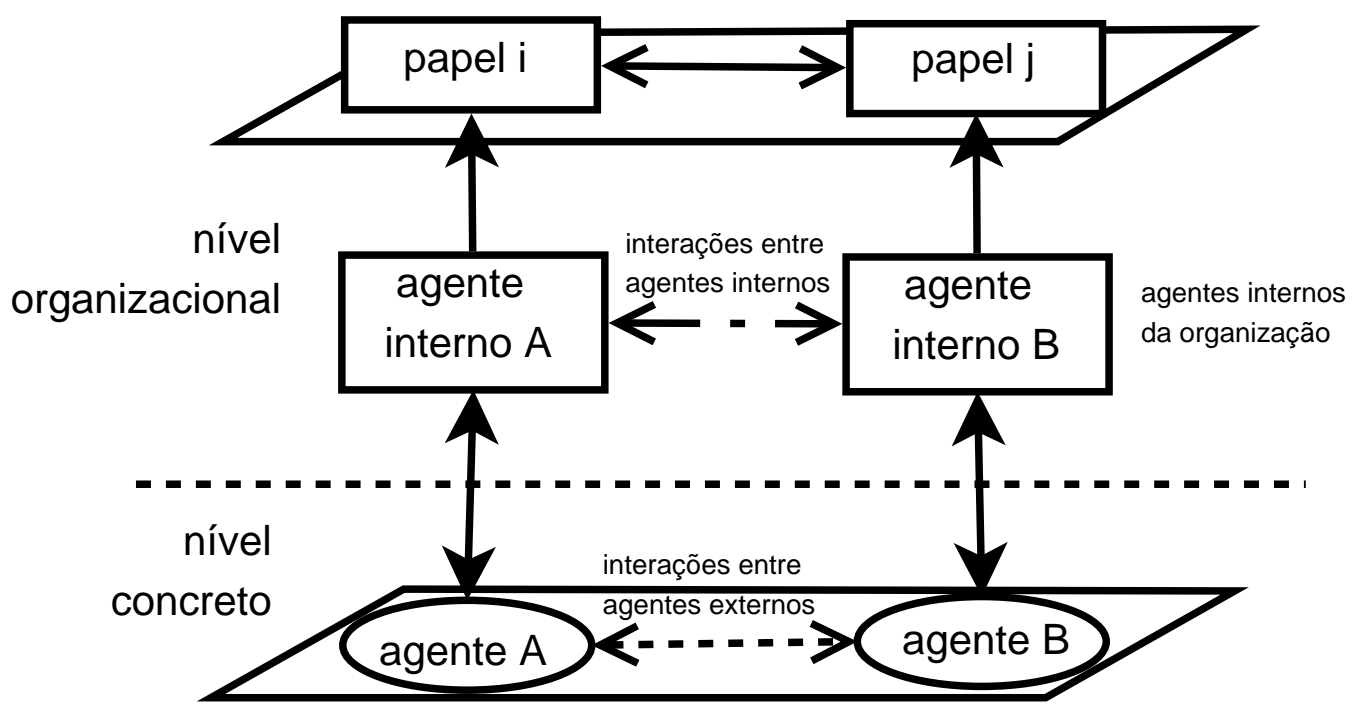

Figura 3.2: Sociedade semi-fechada: agentes dentro da organização são controlados por agentes externos (nível concreto).

Sociedades semi-abertas, semi-fechadas e fechadas possuem restrições e uma linguagem de comunicação fixas. Em sociedades abertas estas duas características são livres ou não existem. Os agentes numa sociedade fechada são conhecidos no momento que a sociedade é projetada, já em sociedades semi-abertas e semi-fechadas são conhecidos em tempo de execução. Em sociedades semiabertas, semi-fechadas e fechadas os papéis dentro da sociedade são conhecidos. Isto não acontece em sociedades abertas.

Note-se que a partir da definição de organização de agentes e autonomia de agentes, um agente pode adotar diferentes papéis definidos na organização por decisão própria. Não é estabelecida nenhuma restrição sobre os papéis que um agente pode adotar dentro de uma organização. Também é necessário notar que as interações entre agentes internos podem ser diferentes das interações entre agentes externos isto por que são definidas pela organização que fazem parte. Na Figura 3.2 as interações entre os agentes internos $A$ e $B$ no nível organizacional são diferentes as interações entre os agentes externos $A$ e $B$ no nível concreto.

Nossa definição de ambiente inteligente se encontra exclusivamente no nível organizacional da Figura 3.2. Que define uma sociedade semi-fechada composta por um conjunto de papéis, interações entre estes papéis e os agentes que representam agentes externos. Não é feita nenhuma definição sobre agentes no nível concreto.

\subsection{Nossa definição de ambiente inteligente}

Baseados nas idéias apresentadas nas seções anteriores definimos um ambiente inteligente como:

Uma organização de agentes definida pelas interações entre agentes que se encontram em espaços físicos.

Esta organização é definida abstratamente no nível organizacional e determina as possíveis interações entre agentes no nível concreto que podem acontecer no contexto dos espaços físicos. Estas interações, de maneira geral, são representadas como relacionamentos possíveis entre papéis da organização. Agentes fazem parte desta organização com o propósito de interagir com outros agentes dentro da organização.

Esta definição de ambiente inteligente tem como consequência os seguintes pontos:

1. dispositivos e interfaces humano computador são representados como agentes [MM09b, HMSK11, PLFN11]; 
2. agentes são os únicos com capacidade de processamento: o ambiente inteligente somente é encarregado de ativar interações entre agentes e fornecer informação de contexto de outros agentes e dispositivos quando requerido;

3. não é feita nenhuma suposição sobre a implementação e estado interno dos agentes: estes podem implementar modelos de inteligência complexos, serem controlados por pessoas ou serem puramente reativos [JSW98];

4. um ambiente inteligente é especificado como interações entre agentes que compõem o ambiente;

5. interações entre agentes são definidas como protocolos de interação através da troca de mensagens e estes protocolos são associados a espaços físicos;

6. agentes dentro de um espaço físico devem ser capazes de interpretar mensagens de interação com o propósito de fazer parte de uma organização e

7. um ambiente inteligente é definido sobre uma estrutura de espaços físicos.

Em nosso modelo, identificamos algumas características que são livremente implementadas com o propósito de não limitar as capacidades de um ambiente inteligente:

infraestrutura: esta característica se encontra na infraestrutura do nível organizacional. Esta característica é implementada pela infraestrutura da organização que ativa interações prédefinidas entre agentes e se baseia em infraestruturas para sistemas multiagentes. Atualmente infraestruturas básicas para sistemas multiagentes dão suporte a [BCG07]: (1) comunicação e interação entre agentes no modelo de comunicação ponto-a-ponto, (2) mobilidade de agentes entre dispositivos e (3) controle remoto do ciclo de vida de agentes.

Esta característica é implementada pelo ambiente de execução do modelo, que se converte em uma plataforma onde agentes fazem parte com o propósito de interagir com outros agentes, segundo as organizações de agentes definidas nos espaços físicos do ambiente inteligente.

interações: nossa abordagem fornece uma linguagem de alto nível que permite a especificação de ambientes inteligentes como interações entre agentes. Esta característica é a mais importante dentro do modelo, pois permite definir interações arbitrárias de um ambiente inteligente. Assim, a definição inicial de interações é feita no momento em que o ambiente inteligente é projetado, e pode ser alterada com novas interações por agentes ou pessoas.

sensibilidade ao contexto: o modelo contém em si próprio sensibilidade à localização de agentes e dispositivos dentro uma determinada área física. Outros tipos de informação de contexto podem ser definidos na linguagem de especificação.

O ambiente de execução fornece o suporte para a integração com outros mecanismos/ferramentas de manipulação de contexto (como MoCA [SER ${ }^{+}$4] ou CoBRA [Che04]), que no mínimo forneçam suporte a: (1) informação da localização física de qualquer dispositivo dentro dos espaços físicos do ambiente e (2) o agente associado a um dispositivo.

inteligência: esta característica é livremente implementada pelas capacidades de raciocínio dos agentes que fazem parte do ambiente, sendo que o princípio da abordagem é não conhecer a tecnologia nem o modelo de inteligência dos agentes.

O único requisito é que agentes devem fazer parte do nível organizacional, com o propósito de interagir com outros agentes, estes agentes devem: (1) interpretar as regras de interação e (2) aceitar e enviar mensagens definidas nas regras de interação. 
adaptação e experiência do usuário: estas características ficam abertas para a implementação de interações especializadas que permitam melhorar a adaptação e experiência das pessoas com sistemas computacionais através de interfaces especializadas.

Neste ponto nossa abordagem dá suporte a abstrair interações com interfaces como interações entre agentes definidas no nível organizacional. Por exemplo, interagir com uma interface numa tela touch-screen ou interagir através de interfaces BCI (Brain-Computer Interfaces visto no do Capítulo 2) iniciariam o mesmo tipo de interações entre agentes.

\subsection{Componentes do modelo para ambientes inteligentes}

O objetivo geral deste trabalho é definir e implementar um modelo para ambientes inteligentes. O modelo está composto por três componentes que implementam diferentes aspectos:

modelo conceitual: define a ontologia de um ambiente inteligente, ou seja, define seus conceitos, entidades (principalmente dispositivos e agentes) e relações.

linguagem de especificação: define uma sintaxe para a especificação de um ambiente inteligente, suas entidades, relações e interações.

ambiente de execução: permite a execução de especificações definidas na linguagem.

\subsubsection{Instituições Eletrônicas como implementação de sistemas multiagentes normativos}

Instituições Eletrônicas fornecem um ambiente organizacional para sistemas multiagentes que permite a execução e cumprimento de normas [GC09]. Este modelo está baseado em autômatos finitos determinísticos onde cada estado contém um conjunto de papéis necessários para uma tarefa específica. A transição entre estados é somente possível quando restrições do estado são satisfeitas - equivalente a normas em sistemas multiagentes normativos. Em [Est03, ANRAS07] é apresentada uma implementação de Instituições Eletrônicas baseada na visão de sociedades semi-abertas e que fornece um mecanismo que garante que se comportem da maneira definida na instituição de que fazem parte.

Instituições Eletrônicas são tomadas como base para definição do modelo conceitual, pois podem ser representadas usando LCC [JdPBR $\left.{ }^{+} 07\right]$. A maior diferença é que o modelo proposto neste trabalho não se baseia em autômatos finitos determinísticos, pois estados na interação surgem de maneira espontânea segundo a descoberta de interações no espaço físico em que agentes se encontram, enquanto que Instituições Eletrônicas foram definidas no cenário da Internet, onde informação de contexto e sua mudança é menos relevante que no cenário de ambientes inteligentes [WA09].

O modelo conceitual define como principais conceitos de um ambiente inteligente: dispositivos, agentes, espaços físicos, interações (definidas como regras de interação), o mecanismo para a descoberta e execução de regras de interação segundo a informação de contexto e o espaço físico em que um agente se encontra.

Uma vez que informação de contexto faz parte intrínseca de um ambiente inteligente [Gag05, WA09], o modelo conceitual associa informação de contexto com regras de interação na sua execução. Localização é um tipo de informação de contexto, portanto regras são associadas a espaços físicos.

Neste trabalho chamamos de instituição de agentes a uma organização de agentes definida através de protocolos de interação.

\subsubsection{LCC como linguagem de especificação}

LCC é uma linguagem poderosa para a modelagem de interações entre agentes através de protocolos de interação no modelo de comunicação ponto-a-ponto [WR02]. A linguagem de especificação 
definida neste trabalho expande a sintaxe do LCC, adicionando uma ontologia para ambientes inteligentes que permite especificar informação de contexto e características do modelo conceitual.

O ambiente de execução permite executar especificações de ambientes definidas na linguagem e contém capacidades tecnológicas para este propósito. A arquitetura do ambiente de execução é baseada em camadas onde cada camada dá suporte a uma funcionalidade específica do modelo. O mecanismo de execução de especificações toma como base o kernel para a execução de especificações em LCC implementado pelo projeto OpenKnowledge [ope].

Assim, a infraestrutura suporta: (1) trocar mensagens ponto-a-ponto entre agentes que fazem parte de uma organização de agentes. Estas mensagens podem conter qualquer tipo de dados, desde tipos básicos até streams de dados; (2) fornecer informação sobre o contexto de qualquer agente; (3) abstrair dispositivos no espaço físico como agentes dentro da infraestrutura. Assim, interações como um dispositivo são feitas através do seu agente associado e (4) gerenciar associações entre definições de normas e espaços físicos do ambiente. 


\section{Capítulo 4}

\section{Componentes do Modelo para Ambientes Inteligentes}

Neste capítulo descrevemos detalhadamente os componentes do modelo proposto introduzidos no capítulo anterior.

\subsection{Modelo conceitual para ambientes inteligentes}

\subsubsection{Um exemplo preliminar}

Apresentamos um exemplo preliminar que mostra de maneira simples a ativação de um ambiente inteligente a partir da interação de dois dispositivos: um dispositivo móvel carregado por uma pessoa e uma câmera de vigilância com capacidade de se movimentar em diferentes direções sobre seu eixo e está instalada no espaço físico do ambiente.

A especificação do ambiente, segundo nossa definição de ambiente inteligente como organizações de agentes, define os papéis user_agent e owner_camera e a interação entre estes, como o envio da mensagem follow do primeiro para o segundo papel. A Figura 4.1 apresenta os agentes associados aos dispositivos que se encontram no espaço físico do ambiente e são: um smartphone carregado por uma pessoa e uma câmera de vigilância que fazem parte do mundo físico. O agente user_a1 é hospedado no smartphone e sua localização está dada pela localização deste. Já o agente camera1 controla a câmera de vigilância através de um componente de software especializado ${ }^{1}$ que acessa o driver da câmera e permite movimentá-la.

A interação é iniciada toda vez que um agente capaz de adotar o papel user_agent entra na área simbólica room1, que representa a sala de um prédio onde a câmera esta instalada. Esta interação acontece enquanto o agente se encontra dentro da sala.

O ambiente inteligente é ativado pela execução desta interação. Quando a pessoa que carrega o smartphone entra na sala do prédio é gerado um evento que informa a mudança na localização do smartphone (e portanto do agente user_a1). Este evento inicia a interação através de dois procedimentos: (1) é recuperada da área simbólica room1 a regra que define esta interação e (2) são selecionados agentes para adotar os papéis definidos nesta interação. A figura mostra que o agente user_a1 adota o papel user_agent e o agente camera1 adota o papel owner_camera.

Desta maneira, o agente user_a1 envia a mensagem follow para o agente camera1 informando sua localização e outras informações. O agente camera1 recebe esta mensagem e se encarrega de movimentar a câmera de vigilância na direção da localização do smartphone (e por tanto da pessoa que o carrega). Esta mensagem é enviada repetidamente até a pessoa sair da sala (junto com o smartphone e portanto com o agente user_a1).

\footnotetext{
${ }^{1}$ http://code.google.com/p/ipcam-viewer/
} 


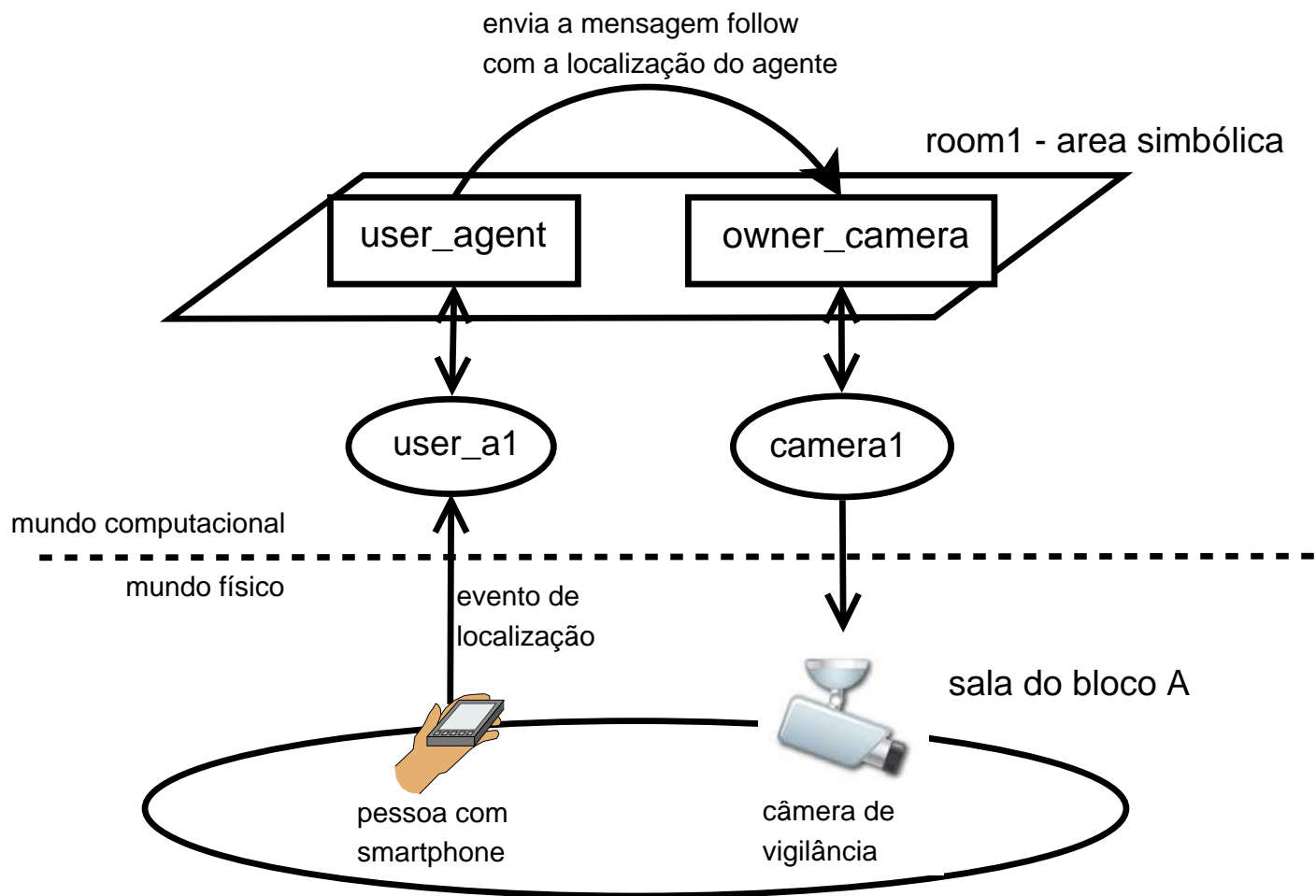

Figura 4.1: Exemplo de um ambiente inteligente como a interação entre um smartphone e uma câmera de vigilância.

É necessário notar os seguintes pontos neste processo:

1. O agente user_a1 registra os papéis que pode adotar por decisão própria com o propósito de fazer parte deste ambiente inteligente.

2. A localização do agente user_a1 é dada pela localização do smartphone dentro da sala, e portanto da pessoa que o carrega.

3. São conhecidos os papéis que podem adotar os dois agentes.

4. Mais de um agente pode entrar na área simbólica e adotar o papel user_agent. Cada um destes agentes inicia a interação descrita.

5. O agente camera1 é o encarregado de processar e escolher (por decisão própria) como movimentar a câmera de vigilância para rastrear uma pessoa dentro da sala.

6. A implementação do agente camera1 pode conter mecanismos de deteç̧ão de faces para focar a câmera da melhor maneira na pessoa que carrega o smartphone.

O modelo é encarregado de efetuar os seguintes pontos neste processo: (1) detecção da entrada do smartphone na área simbólica room1, (2) seleção da interação definida na especificação do ambiente, (3) seleção dos agentes user_a1 e camera1 para fazer parte da interação e (4) envio da mensagem follow entre o agente user_a $\overline{1}$ e camera1 informando a localização do smartphone.

O modelo não cobre os seguintes pontos: (1) informar o conteúdo da mensagem follow -o modelo se encarrega somente de informar a localização do smartphone, (2) implementar o agente camera1 que controla a câmera de vigilância e decide em qual direção movimentá-la.

Na Subseção 4.2.4 apresentamos a especificação deste ambiente inteligente e na Subseção 4.1.3 apresentamos a definição das entidades do modelo como agentes, dispositivos, regras de interação e áreas simbólicas. 


\subsubsection{Fundamentos do modelo conceitual}

Como justificado no capítulo anterior, o modelo proposto considera um ambiente inteligente como uma organização de agentes onde todo processamento é efetuado por agentes. Uma organização define as possíveis interações entre estes agentes como regras de interação que são associadas a espaços físicos do ambiente. Agentes definidos no modelo podem ser construídos com qualquer tecnologia e possuir qualquer modelo de inteligência, com o único requisito de fazer parte da organização que define o ambiente inteligente, isto é, com a capacidade de processar regras de interação.

O modelo considera que são conhecidos os papéis que um agente pode adotar. Desta maneira, um agente registra, no ambiente de execução, os papéis que pode adotar quando faz parte de um ambiente inteligente, e um agente faz parte de um ambiente por decisão própria.

Começamos a descrição do modelo conceitual identificando dois tipos de mundo que diferenciam características peculiares de um ambiente inteligente $\left[\mathrm{RVD}^{+} 05\right]$ e são usados na descrição de diferentes entidades do modelo. Definimos como mundo um conjunto de entidades regidas por algum tipo de leis que determinam seu comportamento. Estes mundos são:

Mundo físico: este mundo está regido pelas leis da física, como localização, gravidade, tempo, espaço, temperatura etc. Neste mundo reconhecemos principalmente as seguintes entidades: pessoas, dispositivos e espaços físicos.

Mundo computacional: neste mundo se encontram quaisquer tipos de sistemas computacionais e considera-se agentes e suas interações como principais entidades.

Estes mundos estão associados um ao outro no sentido que interações no mundo computacional são refletidas no mundo físico e vice-versa. Esta associação entre os mundos é efetivada exclusivamente por agentes, isto é, agentes estão associados a dispositivos (nas próximas seções se apresenta este conceito detalhadamente) no sentido que interações com um agente no mundo computacional podem produzir ações no dispositivo associado ao agente. E no outro sentido, interações com dispositivos no mundo físico são refletidas no agente associado ao dispositivo e podem produzir ações no mundo computacional.

O modelo conceitual segue a linha de computação apresentado em [CB03] e [PMR99], onde se introduz, como principio de computação ubíqua, a integração de computação com o meio físico. Esta abordagem associa a espaços físicos tuplas que são consumidas por dispositivos que se encontram no mesmo espaço físico. Seguindo esta abordagem, o modelo proposto associa regras de interação a espaços físicos no ambiente que determinam as interações entre agentes localizados dentro do espaço físico. Portanto, diferentes espaços físicos no ambiente oferecem diferentes cenários de interações. Por outro lado, também são associadas regras de interação a agentes que caracterizam o escopo de interação do agente as quais podem fazer parte das interações do agente em qualquer espaço físico.

\subsubsection{Entidades do modelo conceitual e suas relações}

Nesta seção apresentamos uma descrição das entidades definidas no modelo conceitual:

Agente: Nesse trabalho não é feita uma discussão sobre agentes, em lugar disto adotamos as definições, características e capacidades de agentes apresentadas em [OZKT01] e [BCG07]. Um agente é um componente de software que opera com uma meta particular, e o modelo conceitual requer que agentes possuam necessariamente autonomia e identidade.

Adicionalmente, consideramos que um agente pode ser: (1) social: para interagir com pessoas e outros agentes, (2) reativo: para monitorar e reagir a mudanças no seu ambiente, composto pelos mundos físico e computacional, (3) proativo: para iniciar interações com seu ambiente, outros agentes ou pessoas de maneira espontânea e (4) móvel: para poder se movimentar entre diferentes dispositivos.

Agentes podem implementar diferentes arquiteturas de raciocínio como: baseadas em lógica, reativas ou BDI (Belief, Desire and Intention) [BHW07]. Agentes também podem possuir 
nenhum tipo de inteligência, quando seu comportamento é totalmente controlado por pessoas. Estes agentes servem de interface para humanos fazerem parte do ambiente inteligente. Pela definição apresentada, o conceito de agente apresentando neste trabalho se refere unicamente a agentes computacionais.

Dispositivo: Definimos um dispositivo como qualquer objeto com capacidade computacional para hospedar agentes, possuir uma representação computacional, ou ambos. A primeira idéia se refere ao conceito tradicional de computador (móvel ou não). A segunda idéia vai de acordo com o principio de computação ubíqua, que define objetos presentes no espaço físico no diaa-dia das pessoas. Os estados físicos destes objetos podem ser controlados e representados computacionalmente, e aqueles objetos que não podem ser controlados não são dispositivos.

Por exemplo, uma porta dotada de sensor para detectar se a porta está aberta ou fechada e com um motor que pode ser controlado computacionalmente (através de algum aplicativo ou API) para conseguir abrí-la ou fechá-la é um dispositivo; uma porta sem estes mecanismos, para nossos fins, não é um dispositivo.

Papel: Papéis representam padrões de comportamento de agentes [GC09] e permitem abstrair e modelar agentes. Interações são definidas sobre papéis e não sobre agentes. Assim, agentes são obrigados a adotar um papel com o propósito de efetuar as interações definidas para o papel associado, e portanto fazer parte da organização definida no ambiente inteligente.

Informação de contexto associada a um papel representa o estado de contexto que um agente deve satisfazer para conseguir adotar o papel. Isto permite que regras de interação sejam executadas dependendo do estado de contexto dos agentes envolvidos.

Área Simbólica: Uma área simbólica é uma representação lógica de um espaço físico, ou parte dele, no ambiente. Áreas simbólicas cobrem regiões arbitrárias de um espaço físico, desta maneira, um espaço físico pode ser representado por uma ou várias áreas simbólicas. Espaços físicos estão definidos por delimitações físicas no ambiente como paredes, portas, andares etc., enquanto que áreas simbólicas são divisões arbitrárias destes espaços físicos segundo as necessidades do ambiente inteligente projetado. Áreas simbólicas são representadas por coordenadas espaciais em formas geométricas arbitrárias.

Por exemplo, face à necessidade de ativar uma televisão 3D na presença da pessoa, é definida uma área simbólica ao redor da televisão (digamos, uma circunferência com raio de 2 metros). Toda vez que for detectada uma pessoa nesta área simbólica a televisão será ligada. Também, um dispositivo está associado a uma única área simbólica, e dispositivos móveis podem mudar de área simbólica ao longo do tempo.

Escopo de Interação: Determina o conjunto de agentes e interações com os quais um agente consegue interagir. Este conjunto é determinado por regras de interação próprias do agente e restrições sobre os agentes com os quais pode interagir.

O escopo de interação de um agente é considerado na descoberta e execução de regras de interação. Este conjunto de regras é opcional e é determinado no momento em que o agente é projetado. As regras de interação deste conjunto são tratadas da mesma maneira que regras associadas a áreas simbólicas e têm por objetivo acrescentar regras que não se encontram na área simbólica em que o agente se encontra.

Regra de Interação: Define a troca de mensagem entre papéis (protocolo de comunicação) seguindo o princípio de speech acts [ANRAS07] onde mensagens recebidas por um agente (que adota o papel) são interpretadas como ordens que devem ser executadas pelo agente. Por exemplo, um agente (associado a uma porta no mundo físico) que recebe a mensagem abre_porta está obrigado a abrir a porta, e é construída a crença de que o agente se encarregará de efetuar o processo necessário para esta ação. 
Por outro lado, regras de interação estão associadas a áreas simbólicas ou a escopos de interação. A descoberta de regras de interação para um agente é feita sobre a união destes dois conjuntos considerando a área simbólica em que se encontra o agente.

Uma regra de interação possui os seguintes elementos:

Emissor: papel do agente que envia a mensagem.

Receptor: papel do agente que recebe a mensagem e a executa.

Mensagem: mensagem enviada pelo emissor. O conteúdo da mensagem depende da ontologia definida pelos agentes.

Informação de contexto: informação de contexto associada aos papéis e mensagens.

Restrição: indica um requisito que o agente no papel do emissor deve satisfazer para conseguir enviar ou receber uma mensagem (este elemento não é obrigatório).

Evento: define o evento que deve acontecer para a regra ser considerada na descoberta de regras de interação (este elemento não é obrigatório).

Meta: descrevem, na ontologia do ambiente inteligente, o estado de contexto que um agente pode alcançar como resultado de executar a regra de interação (este elemento não é obrigatório).

Evento: São ações produzidas por alguma entidade no mundo físico ou computacional. Eventos produzidos por entidades do mundo físico ou computacional iniciam interações com outras entidades através da descoberta de regras de interação.

Eventos são gerados por: (1) agentes, por serem entidades autônomas e (2) por mudança de contexto de entidades no mundo físico ou computacional. Dado que dispositivos e pessoas fazem parte do ambiente somente através de algum agente, eventos gerados por estas entidades são enviadas ao agente associado.

\subsubsection{Associação entre agentes e dispositivos}

Dispositivos se encontram associados a agentes de duas maneiras [SIK04]: (1) um dispositivo com capacidade computacional suficiente para execução do agente -dizemos que o dispositivo hospeda o agente e (2) um dispositivo atualiza seu estado contextual no agente associado, e o estado contextual do dispositivo é atualizado por este agente -dizemos que o agente controla o dispositivo.

\section{Localização de um agente}

Um agente está associado a um espaço físico através do dispositivo associado. Esta associação é necessária para conseguir determinar a localização de um agente no momento de determinar se um agente cumpre as restrições para adotar um papel.

Agentes que não estão associados a nenhum espaço físico são considerados onipresentes, isto é, estão associados a toda área simbólica. Esta última premissa é útil quando são considerados agentes que se encontram fora do espaço físico definido pelo ambiente inteligente. Por exemplo, um agente que implemente o acesso a serviços Web da Amazon pode ser acessado via Internet. Interações com este agente podem ser feitas a partir de agentes em diferentes ambientes inteligentes (como bibliotecas, bancas de jornal em aeroportos, livrarias etc.). Note-se que estes agentes não estão associados a dispositivos e é sua própria implementação que acessa a sistemas externos, portanto, estes agentes não tem nenhuma característica que os faça diferente de outros agentes do modelo. 


\section{Dispositivos controlados por agentes}

Um agente pode controlar um dispositivo e estar hospedado em outro dispositivo. Esta observação se apresenta quando em um ambiente inteligente existem diversos dispositivos inteligentes que precisam atualizar seus estados em um agente para fazer parte do ambiente. Um servidor do ambiente, tipicamente um dispositivo fixo, contém todos os agentes associados a todos estes dispositivos. Pelas características de autonomia e identidade de agentes, um agente pode controlar vários dispositivos mas somente pode estar hospedado por um único dispositivo.

Por exemplo, um servidor do ambiente hospeda um agente encarregado de coletar e processar informação de várias etiquetas RFID (de leitura e escrita); por exemplo, cada etiqueta pode estar colada a um livro de uma biblioteca, permitindo manter informações sobre o livro. Sendo que neste exemplo cada etiqueta representa um dispositivo.

Para um agente conseguir controlar um dispositivo, ele deve possuir um driver que contém todas as operações do dispositivo que permitam interagir com o dispositivo; isto é, um driver fornece para o agente uma API com funções de baixo nível.

Este driver é definido como um componente auxiliar do modelo chamado de Body e tem por finalidade desacoplar a associação agente-dispositivo. Este componente é uma ponte (bridge) entre a infraestrutura do agente e a API do dispositivo, que se encarrega de converter eventos que acontecem no baixo nível do dispositivo em eventos para o agente, e no outro sentido, a ponte permite aos agentes acessar o mundo físico através do dispositivo. Para este propósito, este componente funciona no modelo de subscrição/notificação para o tratamento de eventos.

Nesta visão são identificados dois tipos de agentes:

1. agentes que somente existem no mundo computacional: estes agentes não possuem nenhum dispositivo associado no mundo físico e somente interagem com outros agentes do mundo computacional, mas podem interagir com pessoas caso sirvam como interfaces para entidades humanas. Estes agentes são chamados de servidores pessoais.

2. agentes associados a dispositivos: estes agentes abstraem a interação com dispositivos, posto que interações com o agente são refletidas no dispositivo. Alterações com o dispositivo somente podem ser feitas através do agente associado a ele.

\section{Instanciação agente-dispositivo}

Quando um agente se associa a um dispositivo, o processo é chamado de instanciação agentedispositivo. A instanciação agente-dispositivo é estabelecida no momento que é feita a especificação de um ambiente inteligente, isto na definição declarativa do agente, como veremos na seguinte seção. Além disto, um agente pode se associar a um componente Body dinamicamente por decisão do agente, para isto o ambiente de execução fornece o suporte necessário.

\subsubsection{Ambientes inteligentes, espaços físicos e áreas simbólicas}

Ambientes inteligentes influenciam espaços físicos e espaços físicos são definidos por áreas simbólicas. Desta maneira, espaços físicos e áreas simbólicas formam uma estrutura onde espaços físicos podem estar contidos dentro de outros espaços físicos, o que provoca que áreas simbólicas estejam contidas em outros espaços físicos ou áreas simbólicas.

Por exemplo, considere o espaço físico de um aeroporto contendo os seguintes subespaços físicos: salas de embarque, salas de check-in, corredores, lojas, restaurantes e lugares de estacionamento. Com o propósito de definir um ambiente inteligente para o aeroporto, podem ser definidas áreas simbólicas sobre espaços físicos próprios do aeroporto, como salas de embarque, de check-in e os corredores; e regras de interação somente sobre estas áreas simbólicas. Os outros espaços físicos (lojas, restaurantes e lugares de estacionamento) podem ou não fazer parte do ambiente inteligente do aeroporto associando uma área simbólica a estes espaços. Por sua vez, estes espaços físicos podem possuir um próprio ambiente inteligente contendo outras áreas simbólicas dentro dele. 
Esta estrutura de espaços físicos e áreas simbólicas exige esclarecer o compartilhamento de regras de interação entre áreas simbólicas. Adotamos uma regra simples para este compartilhamento: uma área simbólica contida dentro de outra herda as regras de interação da área simbólica que a contém. Note-se que regras de interação somente são associadas a áreas simbólicas e não a espaços físicos. Seguindo o exemplo anterior, se a área física de uma loja for representada por uma área simbólica no ambiente inteligente do aeroporto, um agente do ambiente inteligente da loja considera as regras de interação associada a uma área simbólica mais as regras de interação definidas na área simbólica definida no ambiente inteligente do aeroporto.

Esta herança de regras de interação entre áreas simbólicas permite compartilhar interações entre ambientes inteligentes contendo outros ambientes inteligentes. Podem ser definidos outros modelos de compartilhamento de regras de interação, como, por exemplo, um modelo baseado em permissões onde privilégios são associados a regras de interação que indicam em quais ambientes inteligentes (ou áreas simbólicas) são aplicáveis.

A Figura 4.2 apresenta estas idéias. A área simbólica $i$ do ambiente inteligente 1 contém o ambiente inteligente 2 o qual define a área simbólica $k$ definida sobre um espaço físico dentro do ambiente inteligente 2. Conforme explicado, regras de interação definidas na área simbólica $i$ serão consideradas por agentes que se encontram na área simbólica $k$.

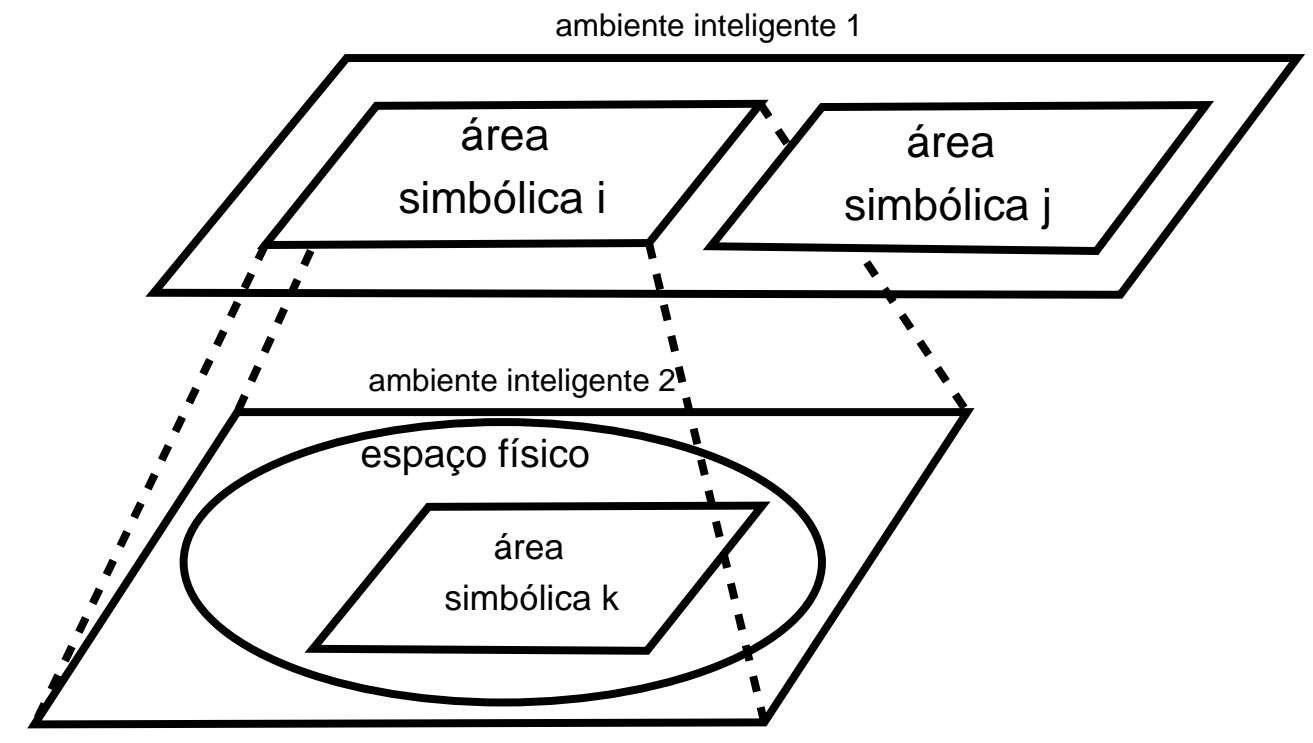

Figura 4.2: Ambientes inteligentes contém espaços físicos que por sua vez contém áreas simbólicas.

\subsubsection{Informação de contexto}

Informação de contexto é indispensável para a detecção de eventos, descoberta e execução de regras de interação. No modelo conceitual são considerados três tipos de informação de contexto:

- contexto físico: localização e orientação de dispositivos no mundo físico. Esta informação é determinada por dispositivos e mecanismos especializados em capturar ou calcular esse tipo de informação.

Por exemplo, a localização de pessoas dentro de um ambiente é determinado por algum dispositivo carregado por elas, como um smartphone com rede Wi-Fi que permita calcular sua posição a partir da potencia do sinal de pontos de acesso visíveis pelo smartphone; ou através de uma etiqueta RFID carregada no crachá da pessoa.

- contexto computacional: memória livre, capacidade de processamento e capacidade de comunicação dos dispositivos. Esta informação é obtida de dispositivos com alguma capacidade computacional. 
- contexto do usuário: perfil e preferencias de pessoas. Informação sobre as características de pessoas no ambiente. Posto que pessoas fazem parte do ambiente inteligente a partir do controle de um agente, é este agente o encarregado de prover esta informação de contexto.

Pelos conceitos apresentados na seção sobre associação agente-dispositivo, o contexto físico de um agente é adquirido a partir do dispositivo associado ao agente, e o contexto computacional de um agente é adquirido a partir do dispositivo que hospeda o agente. No caso do agente ser controlado por uma pessoa, o agente tem associado a ele o contexto do usuário dessa pessoa.

Um dispositivo possui informação de contexto computacional e físico. Esta afirmação é sempre cumprida a partir de nossa definição de dispositivo, que são objetos dotados com algum mecanismo (tipicamente sensores) que permite determinar seu estado físico.

Agentes e dispositivos são os principais produtores de informação de contexto no modelo e são obrigados a atualizar e disponibilizar esta informação para outras entidades do modelo através do ambiente de execução ou de serviços especializados. Um serviço de GPS ou o serviço LIS (Location Inference Service) do MoCA [SER $\left.{ }^{+} 04\right]$ são serviços especializados que fornecem localização de dispositivos. Quantidade de memoria, potencia de sinal são coletadas com chamadas de funções no driver do dispositivo (componente Body). Desta maneira, serviços especializados e componentes Body são considerados também fornecedores de informação de contexto.

\subsubsection{Eventos nos mundos}

As ocorrências de eventos são notificadas a agentes específicos que se subscrevem a determinados tipos de eventos. Eventos são gerados por mudanças em determinada informação de contexto. Por exemplo, quando um dispositivo (carregado por uma pessoa) se movimenta para outra área simbólica, esta mudança é notificada a um agente subscrito para este tipo de evento.

Mecanismos encarregados de fornecer informação de contexto detectam e notificam eventos nos mundos. Assim, conforme visto na subseção anterior, componentes Body e serviços especializados detectam e notificam eventos a agentes interessados. Desta maneira, um evento é associado a um agente, e chamamos este agente de agente receptor do evento.

No modelo conceitual consideramos que eventos que acontecem em qualquer dos mundos iniciam interações entre agentes do mundo computacional. São considerados os seguintes eventos em cada um dos mundos:

- mundo físico: são considerados os seguintes eventos: (1) mudança na localização física de dispositivos, ou seja mudança de área simbólica de algum dispositivo e (2) mudanças no estado físico de objetos. O segundo tipo de eventos são descritos através da ontologia definida para o ambiente inteligente.

- mundo computacional: são considerados: (1) estabelecimento de comunicação entre dois agentes, (2) um dispositivo estabelecer conexão física com uma rede ou com outro dispositivo, (3) mudanças no contexto computacional associado do agente ou dispositivo associado e (4) adição de novas regras de interação a uma área simbólica.

Note-se que segundo nossa definição de dispositivo, a deteç̧ão de eventos somente é possível desde que objetos estejam dotados com algum mecanismo computacional que detecte mudanças no estado do objeto.

Eventos do mundo computacional estão relacionados a: (1) comunicação entre dois dispositivos e (2) comunicação lógica entre agentes. O primeiro se refere a que dois dispositivos consigam se comunicar empregando alguma tecnologia de comunicação (Wi-Fi, Bluetooth, Wi-Fi Direct etc.) e protocolo de comunicação (TCP/IP, AODV, DSR etc.). O segundo ponto se refere à capacidade de interagir com outro agente através de regras de interação. Por exemplo, um agente pode iniciar interações ao detectar que um dispositivo consegue estabelecer uma conexão com outro dispositivo.

Desta forma, é possível iniciar interações quando dispositivos estabelecem uma conexão usando alguma tecnologia de comunicação. Por exemplo, um agente hospedado em um dispositivo móvel 
com Bluetooth pode interagir com outros agentes em outro dispositivo também com Bluetooth. Como esta tecnologia permite conexões espontâneas entre dispositivos, é possível que agentes interajam de maneira espontânea.

Adicionalmente, agentes como entidades autônomas podem gerar eventos espontaneamente ou no caso de servirem de interface com pessoas, estas pessoas podem gerar eventos.

\subsubsection{Escopo de interação entre agentes}

O escopo de interação permite definir interações para agentes que não são dependentes do espaço físico em que se encontram, e portanto do ambiente inteligente. Além disto, contém definições que estabelecem restrições na participação dos agentes em interações. Estas restrições são declaradas usando a ontologia definida na linguagem de especificação.

São mantidas duas listas de agentes permitidos e de agentes não permitidos com os quais o agente pode interagir. Pela característica de identidade dos agentes, estas listas estão compostas por identificadores de agentes. Podem ser projetados mecanismos mais complexos para definir estas restrições.

\subsubsection{Descoberta e execução de regras de interação}

A descoberta de regras de interação tem por finalidade encontrar o conjunto de regras de interação que iniciam e controlam interações entre agentes no ambiente. Chamamos este conjunto de regras de cenário de interação.

A descoberta de regras de interação é iniciada por dois motivos:

1. eventos gerados no mundo físico ou computacional: regras que não são associadas a nenhum evento são consideradas em todas as interações.

2. agentes tentam conseguir uma meta específica: para isto, as regras de interação são associadas a uma descrição do estado produzido como consequência de executar a regra de interação.

O cenário de interação encontrado é associado ao agente receptor do evento ou ao agente que tenta satisfazer sua meta. Na descoberta são consideradas as regras de interação de: (1) a área simbólica associada ao agente, determinada pelo dispositivo associado ao agente se houver e (2) o escopo de interação do agente receptor do evento. Destes conjuntos são selecionadas (para fazer parte do cenário de interação) as regras que correspondem ao evento ou à meta e regras que não possuem definição de eventos nem metas. No exemplo preliminar da Subseção 4.1.1, o evento gerado é a entrada do agente user_a1 na área simbólica room1. A regra de interação que define o envio da mensagem follow se encontra definida nesta área simbólica e é selecionada por ter na sua declaração o evento gerado (vide especificação do ambiente na Subseção 4.2.4).

Posto que um agente pode se localizar em diferentes áreas simbólicas e com diferentes regras de interação, é possível ter diferentes cenários de interação segundo a área simbólica em que se encontra o agente. As regras de interação associadas ao escopo de interação do agente receptor do evento são regras que sempre serão consideradas na criação do cenário de interação. Regras associadas às metas do agente permitem considerar regras que seriam úteis para conseguir a meta do agente.

A execução de um cenário de interação requer que os papéis definidos nas regras sejam adotados por agentes. Para isto, agentes devem satisfazer a informação de contexto associada ao papel da regra de interação (esta checagem implementa o mecanismo que será apresentado na Subseção 4.2.3). Também, são consideradas as restrições definidas no escopo de interação de cada agente candidato a adotar um papel.

Um agente que faz parte do ambiente registra os papéis que consegue adotar no ambiente de execução. Assim, no momento da busca de agentes é feita uma consulta neste registro por agentes para determinados papéis. Também, são considerados agentes onipresentes (agentes sem área simbólica associada). 
Uma vez iniciada a execução de regras de interação, podem acontecer mudanças na informação de contexto, que quando detectadas (seguindo o mesmo mecanismo de eventos descrito na Seção 4.1.7) leva a que a execução seja parada se as condições iniciais não forem satisfeitas.

Note-se que se o cenário de interação é vazio ou não são encontrados os agentes necessários para adotar todos os papéis definidos no cenário de interação, não acontecem interações entre os agentes.

Resumindo, eventos ou metas produzem a criação de cenários de interação para um agente. São consideradas as regras de interação associadas à área simbólica em que o agente se encontra e o escopo de interação do agente. A execução de cenários de interação requer a instanciação de papéis com agentes que é feita segundo um registro papel-agente mantido pelo ambiente de execução e a informação de contexto do agente candidato a um papel. A interação é executada até ser completada ou até acontecerem mudanças de contexto nos agentes que não satisfaçam mais as condições iniciais. A Figura 4.3 apresenta a ordem em que estes procedimentos são efetuados.

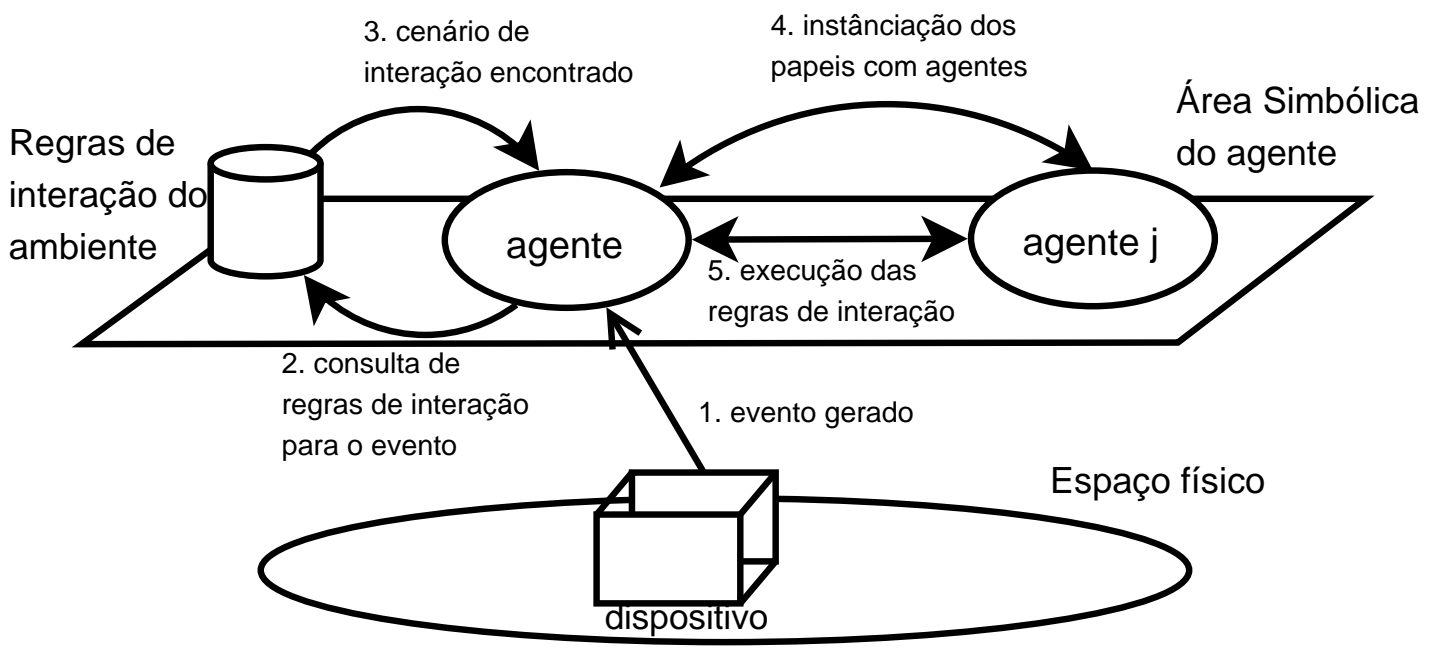

Figura 4.3: Descoberta de regras de interação.

\section{Interações como operações não transacionais e agentes com estado}

Por simplicidade, o modelo conceitual define a execução de regras de interação como operações não transacionais, e agentes mantêm o estado destas interações. Isto é, quando um cenário de interação é definido, o mecanismo de execução considera que a execução do conjunto de regras possa ser interrompida em qualquer momento, e que todos os agentes participantes mantenham o estado desta execução.

Isto traz como consequência principal e fundamental que agentes que adotem papéis no inicio da interação, não possam ser substituídos por outros capazes de adotar os mesmos papéis. Frente a este cenário, a execução de regras são terminadas quando um agente não consegue mais participar de um cenário de interação.

\subsubsection{Atores no projeto de um ambiente inteligente}

É necessário definir também os principais atores na construção e ativação de um ambiente inteligente baseado no modelo proposto:

Projetista do Ambiente Inteligente: (1) define áreas simbólicas no espaço físico do ambiente inteligente, (2) define os papéis necessários encarregados de fornecer as funcionalidades no ambiente, (3) define regras de interação entre papéis do ambiente e (4) estabelece instanciações agente-dispositivo iniciais. 
Desenvolvedor de componentes Body: criadores de dispositivos podem fornecer o componente Body junto com o dispositivo para conseguir fazer parte de um ambiente inteligente. Alternativamente, criadores de agentes podem implementar estes componentes para que seus agentes criados consigam interagir com dispositivos.

Projetista e criador de agentes: é o encarregado de projetar agentes que seguem o modelo conceitual proposto. Como definido, estes agentes podem ser criados com qualquer tipo de inteligência, com a única necessidade de interpretar e processar regras de interação. Na prática isto envolveria possuir um arcabouço que permite interagir com o ambiente de execução.

Usuários: pessoas que carregam algum dispositivo e se movimentam no ambiente inteligente. Instalam agentes no seus dispositivos com o propósito de fazer parte de ambientes inteligentes construídos seguindo o modelo.

Cada um destes atores executa sua tarefa isoladamente o que traz como principal consequência desenvolver dispositivos, agentes e ambientes inteligentes de maneira separada.

Agentes e componentes Body podem ser criados por fabricantes de dispositivos para serem fornecidos junto com seus dispositivos. Agentes cada vez mais inteligentes podem ser criados e oferecidos a usuários para melhorar suas interações no ambiente inteligente. Esta divisão permite evoluir cada área independentemente da outra. Assim, avanços em uma área trazem melhoras em outras.

\subsubsection{Limitações do modelo conceitual}

Existem pontos que não são tratados pelo modelo conceitual. Estes pontos serão tratados em trabalhos futuros. Através da validação do modelo - tarefa também planejada como trabalho futuroserão detectados outros possíveis problemas e limitações não tratados pelo modelo conceitual.

No modelo conceitual é considerado que sub-áreas simbólicas herdam todas as regras de interação da área simbólica que a contém. Neste cenário, podem existir regras de interação que provocam interações inconsistentes entre agentes. Isto pode acontecer, pois as definições de regras de interação das duas áreas simbólicas são feitas separadamente. Por exemplo, um shopping pode definir, na interação entre pessoas localizadas dentro dele, a capacidade de compartilhar recomendações de produtos segundo compras efetuadas por elas mesmas. Em um cinema localizado dentro do shopping, esta interação deveria não acontecer mais, com o propósito de manter as condições adequadas para assistir o filme. Desta maneira, é necessário um mecanismo mais elaborado para compartilhar regras de interação entre áreas simbólicas e tratar interações inconsistentes.

Outro ponto não considerado é a seleção de um agente para adotar um papel ante a possibilidade de existirem vários agentes capazes de adotar um papel. Em princípio, este problema não deveria acontecer, pois todo agente que se registra para adotar um papel é igualmente capaz de efetuar as interações definidas para esse papel (Subseção 3.2.1). No cenário de ambientes inteligentes (regido principalmente pela mobilidade de agentes e dispositivos e pela variabilidade na comunicação) é necessário selecionar o agente mais adequado no referente a confiabilidade de interações e estabilidade na conexão.

A variabilidade de informação de contexto e mudanças na comunicação entre dispositivos ou agentes são características típicas em ambientes inteligentes e trazem como consequência falhas na execução de regras de interação. O modelo considera os mecanismos a seguir para controlar a execução de regras de interação, estes mecanismos são complexos para sua implementação e não foram tratados na definição do modelo conceitual.

1. a definição de regras de interação determina o envio de mensagens alternativas quando estas falham, principalmente por queda de conexão ou demora na resposta dos agentes envolvidos. O projetista do ambiente inteligente é o encarregado por esta parte.

2. o ambiente de execução gera eventos que são tratados por pessoas para efetuar alguma ação. 
Finalmente, questões de privacidade e segurança não são tratadas pelo modelo conceitual. No escopo de interação de um agente são definidas somente restrições sobre os agentes com os quais se pode interagir.

Alguns aspectos do modelo conceitual são complementados pelos outros componentes do modelo proposto. Por exemplo, o monitoramento na execução de regras de interação e a notificação de eventos são efetuados pelo ambiente de execução. Nas seções seguintes apresentamos estes componentes.

\subsection{Linguagem de especificação}

\subsubsection{Fundamentos da linguagem de especificação}

A linguagem de especificação do modelo proposto se baseia no LCC [WR02] (Lightweight Coordination Calculus). O LCC é uma extensão do $\pi$-calculus e se baseia em sistemas multiagentes e trocas de mensagens, permitindo especificar protocolos de interação entre agentes no modelo de comunicação ponto-a-ponto (sem nenhuma entidade central de controle). O LCC foi extendido para especificar o modelo de Instituições Eletrônicas [Est03], criando assim o ambient-LCC [JdPBR $\left.{ }^{+} 07\right]$.

O projeto OpenKnowledge [ope] adotou o LCC como linguagem de especificação para definir interações entre sistemas abertos. Este projeto implementou um middleware para LCC chamado de kernel OpenKnowledge. Este projeto baseou suas idéias em sistemas abertos estáticos (tipicamente serviços Web), focando no compartilhamento de protocolos de interação entre estes sistemas e o alinhamento de diferentes ontologias (ontology matching) para conseguir interoperabilidade.

LCC é uma linguagem adequada para adotar como base para especificar ambientes inteligentes segundo o modelo conceitual apresentado na Seção 4.1. A semântica da linguagem de especificação é dada pelo modelo conceitual e a sintaxe da linguagem se baseia no LCC, permitindo a declaração de entidades do modelo conceitual e a inclusão de informação de contexto na declaração de regras de interação.

A principal diferença entre os protocolos de interação do LCC e as regras de interação da linguagem de especificação é a capacidade de expressar informação de contexto computacional e físico, de tal maneira que não se misture com a especificação de interações. A informação de contexto é relevante e considerada na definição de interações, mas não é própria do domínio de aplicação. A linguagem de especificação define principalmente: (1) entidades definidas no modelo conceitual, (2) informação de contexto e (3) regras de interação baseadas no modelo de comunicação pontoa-ponto. Com este propósito é definida uma ontologia dentro da linguagem de especificação que permite:

- modelar informação de contexto: usada na definição de papéis e mensagens nas regras de interação.

- definir eventos no mundo computacional e físico: usada na descoberta de regras de interação associadas a determinados eventos

Empregamos F-Logic [KLW95] como linguagem para a definição da ontologia da linguagem.

Em [JdPBR $\left.{ }^{+} 07\right]$ é feita uma verificação formal da execução de interações definidas em LCC. Como a linguagem de especificação somente estabelece restrições na seleção de agentes para adotar papéis, a linguagem de especificação mantém a formalidade na definição e execução de interações do LCC.

\subsubsection{Definição da linguagem de especificação}

A seguir descrevemos a sintaxe da linguagem para definir entidades do modelo conceitual e suas relações: 
Agente: Um agente $A$ é definido como:

$$
\operatorname{agent}\left(\mathrm{ID},\left\{\mathrm{R} \_\mathrm{id}\right\},\left\{\mathrm{D} \_\mathrm{id}\right\},\{\mathrm{RI}\},\{\mathrm{SI}\}\right)
$$

onde $I D$ é um identificador único para o agente, $\left\{R_{-} i d\right\}$ é o conjunto de papéis que o agente consegue adotar, $\left\{D_{-} i d\right\}$ é o conjunto de dispositivos associados ao agente, $\{R I\}$ é o conjunto de regras de interação associadas ao escopo de interação do agente e $\{S I\}$ é o conjunto de restrições de interação do agente. Os termos $R_{-} i d$ e $D \_i d$ se referem a identificadores de papéis e dispositivos, respectivamente.

Dispositivo: Um dispositivo $D$ é definido como:

$$
\mathrm{d}(\mathrm{ID}, \mathrm{SA})
$$

onde $I D$ é um identificador único do dispositivo e $S A$ é a área simbólica inicial do dispositivo.

Área simbólica: Uma área $S A$ simbólica é representada como:

$$
\mathrm{SA}(\mathrm{ID},\{\mathrm{RI}\})
$$

onde $I D$ é um identificador único para a área simbólica es $\{R I\}$ é o conjunto de regras de interação associadas à área simbólica.

Escopo de Interação: O escopo de interação $S I$ de um agente é definido como \{ontologia\} que é o conjunto de condições definidas na ontologia da linguagem.

Papel: Um papel $R$ é definido como:

$$
\text { r (ID, initial|necessary, 1) }
$$

onde $I D$ é um identificador único do papel, initial e necessary são qualificadores que informam se um o papel inicia a interação ou se o papel é necessário na interação, respectivamente, o termo 1 indica que é necessário um agente nesse papel para iniciar a interação, este termo é opcional e quando declarado é mantido com 1. Estes dois últimos termos são mantidos da definição de papéis no LCC e é feita dentro da definição de regras de interação.

Regra de Interação: Uma regra de interação $R I$ é definida como o conjunto \{clausula LCC que é um conjunto de cláusulas definidas em LCC segundo a sintaxe definida no Código 4.1. É necessário notar que o termo $a\left(R \_i d, I d\right)$ da linha 3 é mantido do LCC e representa algum agente que adota o papel referenciado pelo argumento $R_{-} i d\left(R_{-} i d\right.$ é o identificador de um papel). Este termo não deve provocar confusão com a definição de agente apresentada anteriormente por dois motivos: (1) é usado no escopo da definição de regras de interação para definir as mensagens de entrada e saída e (2) este termo em si não define um agente segundo o modelo conceitual. Por exemplo, no Código 4.3 a expressão a(user_agent, A1) da linha 8 representa um agente que adota o papel user_agent e que envia a mensagem follow (linha 10) para um agente que adota o papel owner camera representado pela expressão a(owner camera, B1) da linha 11. A definição de um agente capaz de adotar o papel user agent é feita na linha 1, através da expressão agent(user_a1, \{user_agent $\},\{$ aa:bb:cc:dd $\},\{\},\{\}$ ) e a definição do papel é feita na linha 5, através da expressão r(user_agent, initial). 


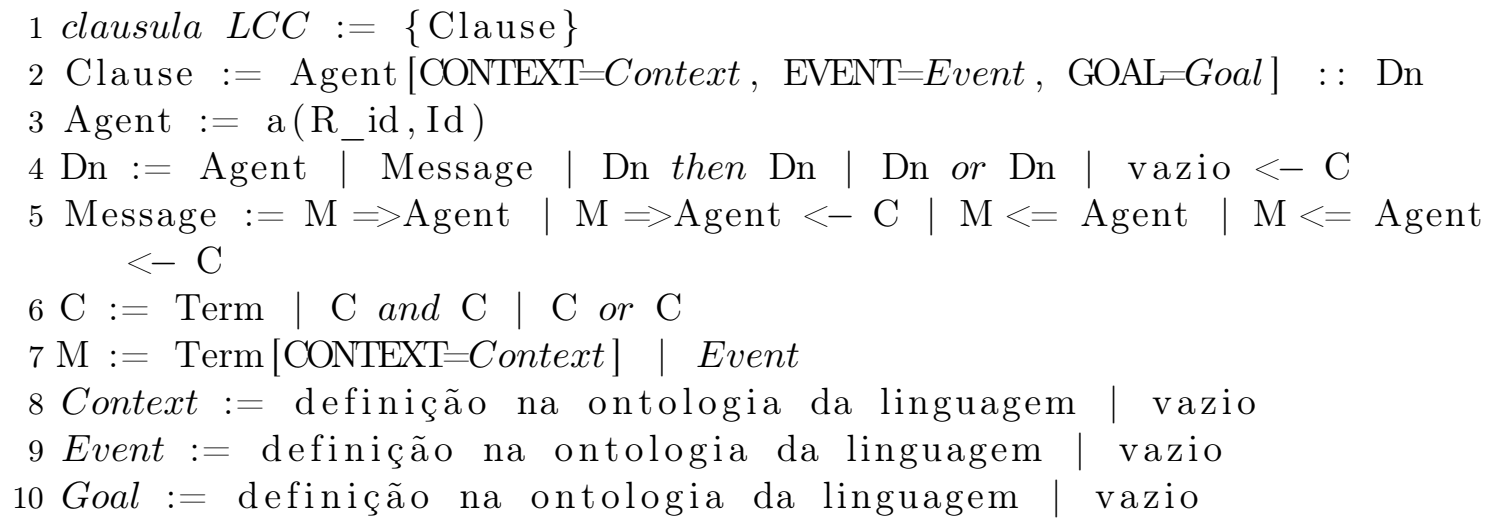

Código 4.1: Sintaxe da Linguagem de especificação.

Uma regra de interação define várias cláusulas em LCC (declarações que iniciam na linha 2), cada cláusula corresponde a um papel definido na especificação do ambiente inteligente. Definimos que um papel da regra de interação é o papel ao qual se refere o $\operatorname{argumento~} R \_i d$ do termo $a\left(R \_i d, I d\right)$ definido em uma cláusula da regra. Por exemplo, o Código 4.3 define uma cláusula que inicia na linha 8 e outra que inicia na linha 15 que correspondem aos papéis definidos nas linhas 5 e 6 , respectivamente, a partir destas cláusulas os papéis da regra de interação são user_agent e owner_camera. É sobre um papel da regra de interação que é associada informação de contexto, evento e meta da regra (Termos Context, Event e Goal da linha 2 no Código 4.1, respectivamente). Por exemplo, no Código 4.3, as linhas 8 e 9 definem um evento e informação de contexto para o papel da regra user_agent, já o papel da regra owner_camera na linha 15 não tem nenhum destes elementos associados.

Note-se que o Código 4.1 define somente regras de interação do ambiente inteligente. A declaração de outras entidades permite criar e inicializar entidades do ambiente inteligente de maneira declarativa através do ambiente de execução.

A seguir detalhamos algumas características na definição de regras de interação usando esta sintaxe:

- Goal, Context e Event são termos definidos na ontologia da linguagem e podem não ser declarados.

- O termo Term denota predicados definidos pelo projetista do agente e do ambiente inteligente e são usados na definição de mensagens e condições. Estes predicados são dependentes do domínio de aplicação do ambiente.

- Informação de contexto é associada a um papel da regra de interação através do termo Context na linha 2. Também é associada informação de contexto nas mensagens entre agentes através do termo Context da linha 7.

- O evento associado a um regra de interação é definido em um papel da regra através do termo Event da linha 2. Isto indica que o evento deve ser recebido por um agente que adota o papel da regra associado.

- A meta associada a uma regra de interação é definida em um papel da regra através do termo Goal da linha 2. Isto indica que a meta pertence a um agente que adota o papel da regra associado.

- O termo Id da linha 3 é um átomo que identifica um agente e fica no escopo da regra de interação. É usado para distinguir agentes com o mesmo papel na mesma regra. Este identificador não é o identificador do agente desde que um agente adotara um papel somente na execução das regras. 
- A linha 7 permite o envio de eventos entre agentes do mesmo jeito que mensagens.

Pontualmente, a sintaxe do LCC na declaração de interações foi extendida com a expressão [CONTEXT =Context, EVENT =Event, GOAL=Goal] da linha 2 e o expressão [CONTEXT=Context $]$ da linha 7.

\subsubsection{Ontologia da linguagem e inferência de informação de contexto e eventos}

No Apêndice B.2 apresentamos a ontologia definida da linguagem de especificação em WSML ${ }^{2}$ (Web Service Modeling Language), que é uma variante da sintaxe de F-Logic, e pode ser convertida em $F$-Logic diretamente. Definimos os conceitos e as propriedades mínimas suficientes para expressar a informação de contexto, metas e eventos definidos nas Seções 4.1.6 e 4.1.7. É possível enriquecer esta ontologia para modelar e processar outros tipos de informações, mas para nossos propósitos esta ontologia cobre informações relevantes para o modelo.

Os conceitos das linhas 10 até 23 (o Código 4.2 apresenta uma parte da ontologia) representam identificadores únicos de entidades do modelo que são: agentes (conceito AgentID), dispositivos (conceito DevideID), áreas simbólicas (conceito SymbolicArealD) e papéis (conceito Rolelnfo). A linha 25 representa uma regra de interação que contém um identificador da regra (atributo id) e um conjunto de conceitos Term (linas 29 até 30) que são representados como string, que são cláusulas em LCC. Os conceitos UserContext, PhysicalContext e ComputationalContext são sub-conceitos de ContextInfo que representam a informação de contexto do usuário, físico e computacional, respectivamente.

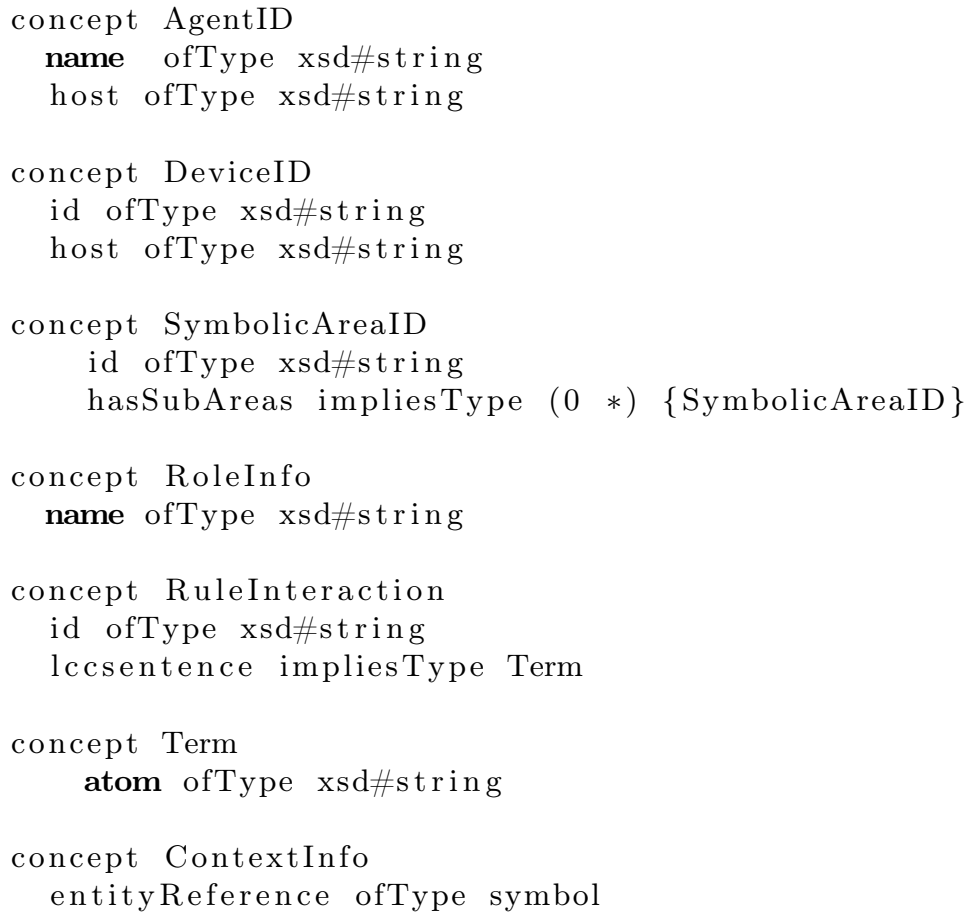

Código 4.2: Principais entidades do modelo definidas na ontologia da linguagem.

A separação na definição de interações e informação de contexto tem como propósito principal não misturar uma linguagem baseada em lógica de predicados (LCC) com uma linguagem baseada em lógica descritiva (WSML). Isto traz como beneficio que é possível manter a formalidade de interações do LCC, e aproveitar as vantagens da WSML na modelagem de informação de contexto e inferência sobre esta informação. Desta maneira, o uso de WSML tem como principal finalidade a modelagem de eventos e informação de contexto, e de LCC a definição de interações.

A definição de informação de contexto através de WSML permite aplicar inferência em lógica descritiva para determinar se as informações de contexto de um agente satisfaz a informação de

\footnotetext{
${ }^{2}$ http://www.wsmo.org/wsml/
} 
contexto declarada no papel da regra de interação que o agente deseja adotar. Um agente pode adotar este papel se satisfaz a consequência lógica da seguinte equação:

$$
\text { Ontologia } \wedge K B_{\text {agente }} \vdash \text { Papel }_{\text {contexto }}
$$

Onde Ontologia é a ontologia da linguagem descrita anteriormente, $K B_{\text {agente }}$ é a informação de contexto corrente do agente (chamado de base de conhecimento do agente) e Papel $_{\text {contexto }}$ é a informação de contexto do papel da regra de interação (termo Context da linha 2 do Código 4.1) que o agente deseja adotar. Em lógica descritiva, esta equação significa que a informação de contexto do papel pode ser provada a partir da ontologia da linguagem e do estado de contexto do agente.

Um mecanismo similar é implementado para selecionar regras de interação associadas a eventos, como apresentado na Subseção 4.1.9. Uma regra é selecionada se o evento gerado satisfaz a consequência lógica da seguinte equação:

$$
\text { Ontologia } \wedge \text { Evento } \vdash \text { Papel }_{\text {evento }}
$$

Onde Evento é o evento gerado e Papelevento é o evento associado a um papel da regra de interação sendo avaliada (termo Event da linha 2 do Código 4.1). A seleção de regras de interação para metas de agentes segue o mesmo mecanismo.

Na Subseção 5.3.4 do Capítulo 5, referente a experimentos e resultados, é feita uma maior descrição desta ontologia desde que se encontra associada com o caso de estudo apresentado neste capítulo.

\subsubsection{Definição de interações em LCC com informação de contexto}

Nesta subseção descrevemos a especificação do ambiente inteligente apresentado na Subseção 4.1.1. O Código 4.3 corresponde à especificação deste ambiente na linguagem apresentada anteriormente. Também descrevemos a sintaxe do LCC para definir interações e a declaração de eventos e informação de contexto em F-Logic.

São definidos os agentes user_a1 e camera_a1 (linhas 1 e 2), com os papéis user_agent e owner_camera, respectivamente, que adotam seus respectivos papéis quando se localizam na área simbólica room1. Na linha 4 é definida a área simbólica room1 com uma regra de interação. Conforme descrito no exemplo preliminar, esta regra é iniciada quando um agente que pode adotar o papel user_agent ingressa na sala, isto é definido pela expressão _P:PhysicalEvent[symbolicAreaReference $->$ room1] da linha 8.

Esta última expressão corresponde a uma sentença em F-Logic onde PhysicalEvent é um conceito definido na ontologia da linguagem que se refere a um evento do mundo físico (como descrito na Subseção 4.1.7) e symbolicAreaReference é a propriedade do conceito que se refere à área simbólica na qual aconteceu o evento, que no caso se refere à área simbólica room1. _P é uma variável anônima (variáveis começam com o símbolo _) que indica que o conceito deve ser unificado com um fato na base de conhecimento do agente. De forma geral, expressões em F-Logic tem a forma variável:conceito/propriedade1 -> valor1, propriedade2 -> valor2, .../. Em principio esta expressão é suficiente para expressar eventos e informação de contexto na linguagem, outras expressões em F-Logic podem ser encontradas em [KLW95].

$\mathrm{O}$ símbolo $=>$ (na linha 11) indica o envio da mensagem follow(PeerID) do agente que adota o papel user_agent para o agente que adota o papel owner_camera. Esta é uma mensagem de saída. Uma mensagem de entrada é definida com o símbolo $<=$ como mostra a linha 16. Junto com a mensagem follow é enviada a localização do agente que adota o papel user_agent, isto é definido através da expressão _P:PhysicalContext[inSymbolicArea -> _SA] da linha 10. A variável _SA (na declaração de mensagens) é preenchida pelo ambiente de execução quando envia a mensagem.

O envio e recepção de mensagens são efetivados quando a restrição associada é satisfeita pelo agente que envia ou recebe a mensagem. A expressão <- recoverld(PeerlD) (linha 11) é a restrição associada ao envio da mensagem follow descrita acima. Um agente satisfaz uma restrição unificando 
os argumentos definidos na restrição. No exemplo, isto corresponde a associar um valor para o argumento PeerlD. A execução de regras de interação usa os valores atribuídos aos argumentos na restrição para criar a mensagem. No exemplo, o argumento PeerlD da mensagem follow(PeerlD) é preenchido com o valor que foi atribuído na restrição.

A palavra chave then indica o envio ou recepção de mensagens em sequência. No exemplo, a linha 12 indica que depois de enviar a mensagem follow é executada a expressão a(user_agent, A1) que indica recursividade na interação. O LCC também define a palavra chave or que indica disjunção no envio de mensagens, isto é, ou é enviada uma mensagem ou é enviada outra, dependendo se o agente satisfaz a restrição associada a cada mensagem.

A recursividade da linha 13 é mantida enquanto a informação de contexto da linha 9 for cumprida. Ela define que o agente que adota o papel user_agente esteja localizado na área simbólica room1. Quando este agente sair da sala esta interação é terminada.

Em uma regra de interação é declarada uma cláusula por cada papel. Na linha 8 é declarada a cláusula para um agente que adota o papel user_agente e na linha 15 é declarada a cláusula para um agente que adota o papel owner_camera. O envio de uma mensagem tem a declaração correspondente em ambas cláusulas. Por exemplo, a mensagem follow é uma mensagem de saída correspondente ao papel da regra user_agente (linha 11) e também é uma mensagem de entrada correspondente ao papel da regra owner_camera (linha 16).

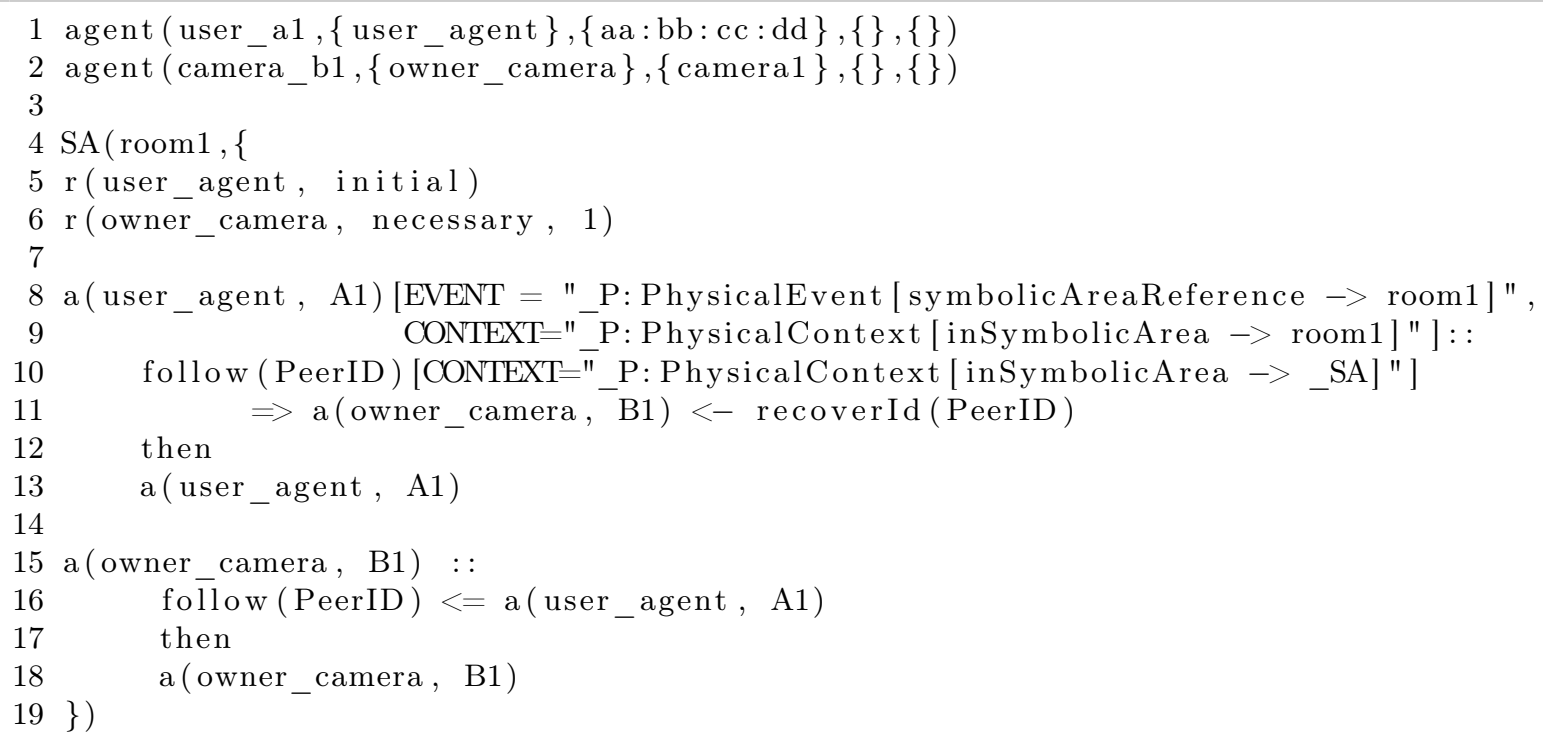

Código 4.3: Exemplo de especificação de um ambiente inteligente como a interação entre um smartphone e uma câmera de vigilância.

Restrições são opcionais para o envio ou recepção de mensagens e neste caso uma mensagem é tratada diretamente pelo agente. Restrições nas regras de interação são tratas pelo agente e são estes os encarregados de satisfazê-las ou não por decisão própria.

A sintaxe na declaração de regras de interação é mantida do LCC. Em [WR02] pode-se encontrar uma descrição mais detalhada da especificação de interações e podem ser usadas neste trabalho.

\subsection{Arquitetura do ambiente de execução}

Este componente do modelo tem como propósito exclusivo a execução de especificações feitas na linguagem e não dá suporte à implementação de agentes.

Neste trabalho foi implementado um protótipo do ambiente de execução com o propósito de exemplificar aspectos importantes do modelo e conseguir executar as especificações do caso de estudo apresentado no Capítulo 5.

O ambiente de execução fornece o seguinte suporte para a execução de especificações: 
1. Registro de papéis e componentes Body: agentes que fazem parte de um ambiente inteligente registram no ambiente de execução os papéis que podem adotar e componentes Body dos dispositivos associados. Esta informação é necessária para a determinar quais agentes podem adotar os papéis definidos nas regras de interação.

2. Detecção de localização de dispositivos e disponibilização de informação de contexto: a partir dos componentes Body registrados, o ambiente de execução detecta a localização de dispositivos e notifica eventos de localização quando um dispositivo muda de área simbólica, estes eventos são enviados a agentes receptores destes eventos, como descrito na Subseção 4.1.7. Também disponibiliza informação de contexto computacional dos dispositivos associados a agentes. A informação de contexto computacional dos dispositivos fornecida pelo ambiente de execução é descrita na Subseção 4.1.6.

3. Descoberta de regras de interação e inicio de interaçôes: frente à detecção de um evento de localização o ambiente de execução implementa a descoberta de regras de interação segundo o processo descrito na Subseção 4.1.9. Para este propósito, o ambiente de execução mantém um registro de áreas simbólicas do ambiente e regras de interação associadas a estas áreas.

4. Execução de regras de interação: o ambiente de execução seleciona agentes para adotar papéis consultando o registro papel-agente e obtendo a informação de contexto corrente dos agentes candidatos. Para este ponto, e o anterior, o ambiente de execução implementa o mecanismo de inferência na ontologia da linguagem descrita na Subseção 4.2.3. O ambiente de execução interpreta as regras de interação para determinar as mensagens que devem ser transmitidas e se encarrega de transportá-las entre os agentes envolvidos.

Em cada mensagem transportada o ambiente de execução se encarrega de: (1) checar a disponibilidade dos agentes envolvidos, (2) colocar informação de contexto declarada na mensagem e (3) checar se os agentes cumprem com a informação de contexto definida no papel que adotaram no inicio da interação.

5. Comunicação entre agentes em diferentes dispositivos: o ambiente de execução transporta mensagens entre diferentes dispositivos que hospedam agentes.

Projetistas e criadores de agentes são encarregados de implementar os pontos a seguir, além de implementar as funcionalidades próprias do agente.

1. Processar as mensagens de entrada: mensagens contém as informações definidas nos argumentos da mensagem e também a informação de contexto do agente emissor da mensagem.

2. Informar os argumentos das mensagens de saída: devem ser informados todos os argumentos definidos na mensagem de saída. O ambiente de execução se encarrega de criar a mensagem e encaminhá-la para o agente receptor.

3. Interações específicas com dispositivos: o criador do agente usa tecnologias específicas para implementar as funcionalidades do agente ou para interagir com o dispositivo associado ao agente.

Na prática, a API fornecida pelo ambiente de execução (Apêndice A) permite a um agente: (1) receber as mensagens de entrada encaminhadas pelo ambiente de execução e (2) disponibilizar informações para a criação de mensagens de saída a serem transportadas pelo ambiente de execução.

Uma única instância do ambiente de execução é executada em cada dispositivo com o propósito de ativar interações entre os agentes que hospeda e os agentes em outros dispositivos. A Figura 4.4 mostra as camadas do ambiente de execução e projetos ou abordagens que podem ser usados para implementar cada camada. De baixo para cima, a camada de infraestrutura possui menor nível de abstração e a camada de inteligência organizacional possui o maior nível de abstração no referente a 


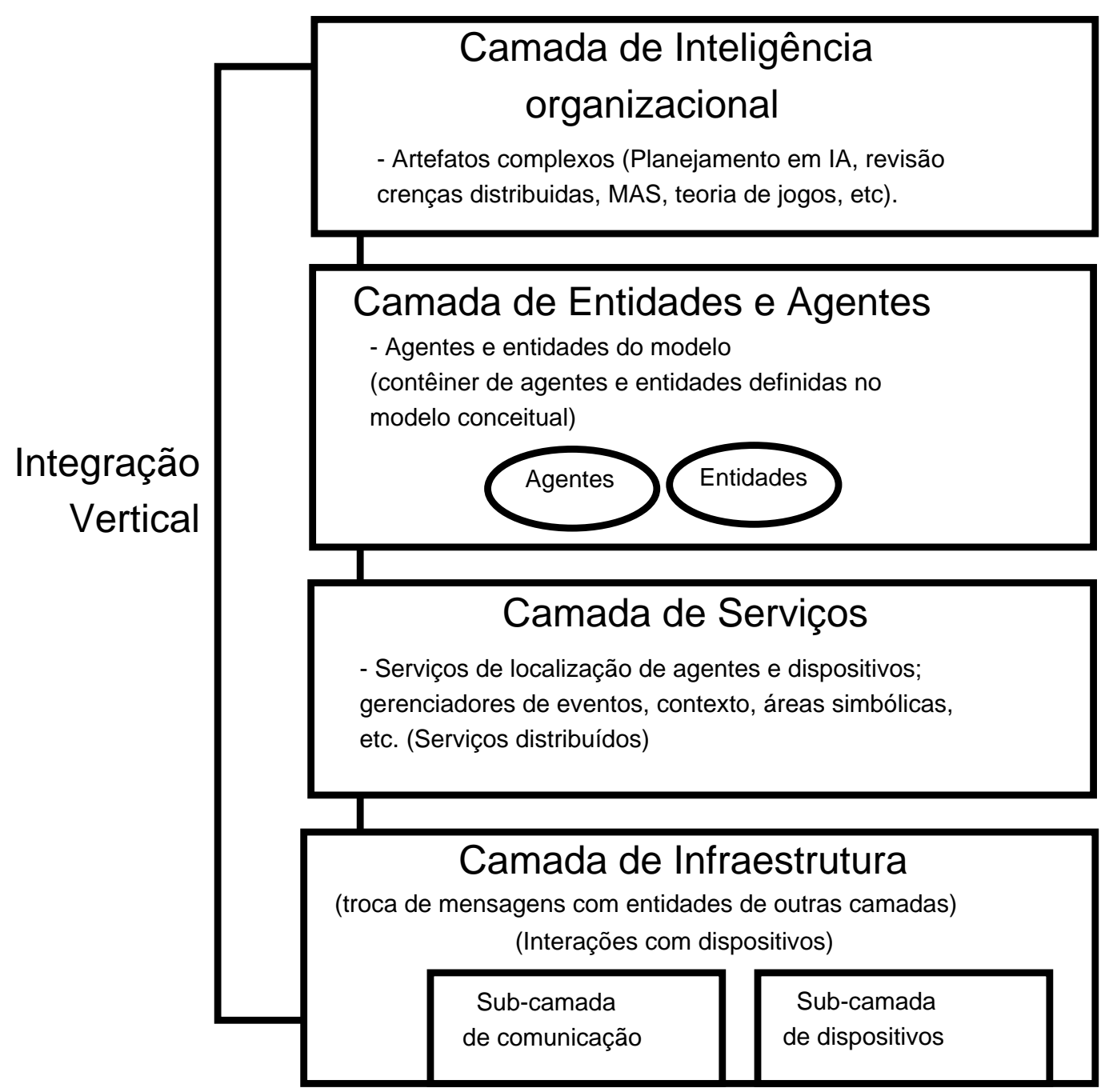

Figura 4.4: Camadas do ambiente de execução.

aspetos de implementação. Nas camadas superiores não é preciso saber como foram implementadas as funcionalidades de camadas inferiores e pode-se apenas utilizar essas funcionalidades.

Cada camada define diferentes entidades como elementos de primeira classe próprios de cada camada:

1. camada de infraestrutura: tem contato direto com a tecnologia de comunicação dos dispositivos.

2. camada de serviços: suporta diversos serviços que implementam funcionalidades específicas do modelo.

3. camada de entidades do modelo e agentes: gerencia o ciclo de vida de instâncias de entidades definidas no modelo. No modelo proposto, esta camada suporta agentes, regras de interação, componentes Body e áreas simbólicas.

4. camada de inteligência organizacional: gerencia entidades mais complexas (artefatos de conhecimento [STCDS $\left.{ }^{+} 08\right]$ ), encarregadas de implementar algum tipo de inteligência e coordenação entre entidades de camadas inferiores. Em nosso caso esta camada contém o artefato que implementa o mecanismo de interação entre agentes baseado em organizações de agentes dirigidos por espaços físicos. 
No referente ao modelo conceitual proposto, a arquitetura do ambiente de execução permite que as camadas inferiores forneçam suporte a camadas superiores com base em abstrações relacionadas a funcionalidades de ambientes inteligentes. É possível acessar as funcionalidades das diferentes camadas (integração vertical) com o propósito de conseguir funcionalidades mais relevantes e ricas. Por exemplo, implementar um mecanismo que permita montar as mensagens de envio diretamente na camada de infraestrutura permitiria o envio de entidades (como agentes ou regras de interação) de maneira personalizada. Em nosso modelo, isso permitiria, por exemplo, compartilhar agentes entre usuários. Esta funcionalidade é suportada por plataformas como o Jade para implementação de agentes.

\subsubsection{Camada de infraestrutura}

Esta camada tem contato direto com os dispositivos que existem no ambiente inteligente, cumprindo as seguintes funções: (1) fornecer uma infraestrutura de comunicação entre dispositivos, permitindo a movimentação de entidades de camadas superiores e (2) permitir interagir com dispositivos de baixo nível.

\section{Sub-camada de comunicação}

Esta sub-camada faz uso da tecnologia de comunicação presente nos dispositivos do ambiente (como Wi-Fi, Bluetooth, Wi-Fi Direct etc.) e da arquitetura de comunicação (como ponto-a-ponto, infraestrutura, ad-hoc ou cliente/servidor). É considerado o projeto Jade [BCG07] como modelo de comunicação. O Jade implementa o modelo de comunicação FIPA para sistemas multiagentes, mas também pode ser perfeitamente usado para permitir:

- transportar entidades de outras camadas entre diferentes dispositivos, como agentes, regras de interação, mensagens, artefatos etc;

- fornecer um ambiente de comunicação comum;

- ativar a comunicação entre diferentes plataformas e dispositivos.

Jade implementa o modelo de comunicação ponto-a-ponto, ativando a comunicação entre dispositivos fixos ou móveis.

É possível inclusive transportar artefatos da camada de inteligência organizacional, o que é útil para fins de distribuição ou atualização de versões.

\section{Sub-camada de dispositivos}

Esta camada funciona como repositório de componentes Body, definidos na Sub-seção 4.1.4, através dos quais é possível interagir com dispositivos no ambiente. Ela também se encarrega de detectar eventos que aconteçam nos dispositivos e enviá-los a entidades interessadas de camadas superiores.

Empregando a capacidade de transportar diversas entidades entre dispositivos da sub-camada de comunicação, é possível atualizar componentes Body segundo seja necessário permitindo que diferentes agentes acessem estes dispositivos.

\subsubsection{Camada de serviços}

Esta camada contém serviços com o propósito de manter informação compartilhada e atualizada de entidades do modelo. Estes serviços fornecem funcionalidades específicas, como serviços de localização de agentes e dispositivos, gerenciador de áreas simbólicas, detecção de conexões, gerenciador de eventos, gerenciador de informação de contexto etc.

São implementados os seguintes serviços que dão suporte a funcionalidades pontuais na execução de regras de interação: 
RoleSubscribeService: mantém o registro de papéis de agentes. Está informação é consultada no momento da execução de regras de interação.

SymbolicAreaService: mantém o registro de áreas simbólicas e regras de interação definidas em cada área. Este serviço é consultado por regras de interação registradas em cada área simbólica.

ContextService: mantém a informação de contexto físico e computacional de cada agente. Também, este serviço é consultado na descoberta de regras de interação.

DeviceAgentService: mantém o registro de dispositivos (componentes Body) associados a cada agente.

RepositoreService: mantém informação sobre declarações de entidades do modelo como: áreas simbólicas, regras de interação, dispositivos e definições de agentes.

LocationService: mantém a área simbólica em que se encontram os dispositivos. Este serviço se comunica com o mecanismo de localização para manter sua informação atualizada.

Estes serviços são implementados de maneira simples através de replicação de informação, isto é, a informação de um determinado serviço é replicada entre todas as instâncias do ambiente de execução que implementam o serviço. Desta maneira, um serviço implementado no ambiente de execução é visto como único entre os diferentes dispositivos (móveis ou fixos). Esta idéia é apresentada na Figura 4.5. Este mecanismo não é o mais eficiente para manter esta informação consistente (especialmente no cenário da computação móvel) pudendo ser usados outros mecanismos. Mas para os propósitos dos experimentos realizados esta implementação foi suficiente.

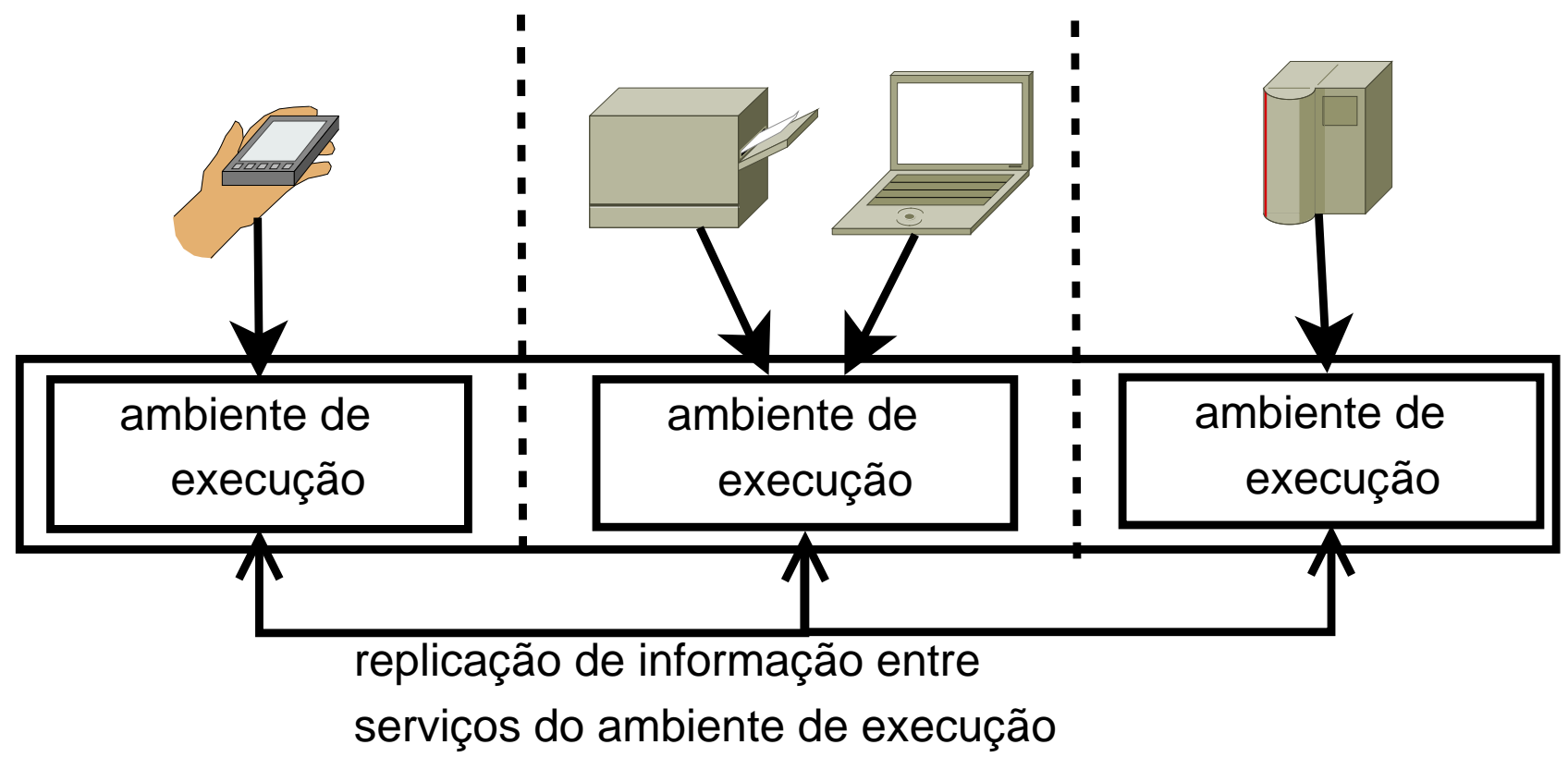

Figura 4.5: Serviços distribuídos entre instâncias do ambiente de execução.

De maneira geral, para a ativação do modelo conceitual proposto estes conjuntos de serviços devem permitir:

- processamento e coleta de informação de contexto do ambiente, implementados por mecanismos como os apresentados em [SER $\left.{ }^{+} 04\right]$;

- diretório e descoberta de entidades de camadas frente a mobilidade e localização, como o middleware apresentado em [IST $\left.{ }^{+} 05\right]$; 
- gerenciador de espaços físicos, como apresentado em [Nor07].

- serviços para inferência, descoberta de regras de interação, como o modelo apresentado em [ope].

- gerenciamento e compartilhamento de ontologias do ambiente, implementados por mecanismos como os apresentados em [Che04];

\subsubsection{Camada de entidades do modelo e agentes}

Como implementação do modelo conceitual proposto, esta camada contém, principalmente, agentes que implementam funcionalidades do ambiente inteligente. Também contém representações dos conceitos definidos no modelo conceitual como: áreas simbólicas, eventos, regras de interação, escopos de interação e papéis. Neste camada é feita a descoberta de agentes e entidades com base em funcionalidades requeridas por camadas superiores. Esta camada fornece:

- o gerenciamento de agentes e outras entidades, considerando que esta camada é encarregada de controlar a troca de entidades entre dispositivos do ambiente;

- um mecanismo de descoberta de agentes e entidades que permite a instanciação de regras de interação.

Assim, resumidamente, esta camada se encarrega de disponibilizar e hospedar agentes e entidades para a camada de inteligência organizacional, usando os serviços fornecidos pela camada de serviços.

\subsubsection{Camada de inteligência organizacional}

Contém artefatos complexos implementados com modelos de interação específicos para ambientes inteligentes baseados em sistemas multiagentes. No presente trabalho, esta camada contém o artefato que implementa o modelo conceitual baseado em organizações de agentes e dirigido por espaços físicos.

Estes artefatos são implementações suportadas por camadas inferiores do ambiente de execução.

Assim, artefatos desta camada são entidades complexas que ativam a coordenação de atividades de entidades de outras camadas. A construção destes artefatos pode se basear em outras abordagens como [DL95]:

- teoria dos jogos;

- sistemas de manutenção de verdade distribuídos;

- coordenação de sistemas multi-agentes;

- planejamento em IA.

\section{Implementação do ambiente de execução}

A implementação do ambiente de execução foi feita para a plataforma Android em dispositivos móveis, e usamos JavaSE 6.0 para dispositivos com maior capacidade computacional.

Utilizamos a versão do Jade para Android ${ }^{3}$ na sub-camada de comunicação.

Por outro lado, empregamos o MoCA [SER $\left.{ }^{+} 04\right]$ para a coleta e processamento de informação de contexto e principalmente, para ativar a localização de dispositivos em áreas simbólicas.

\footnotetext{
${ }^{3}$ http://jade.tilab.com/doc/tutorials/JadeAndroid-Programming-Tutorial.pdf
} 


\subsubsection{Considerações na implementação do ambiente de execução}

É importante ressaltar que o ambiente de execução não pretende ser um arcabouço para a construção de ambientes inteligentes. Existem diferentes requerimentos tecnológicos na construção de um ambiente que não são cobertos pelo ambiente de execução, por exemplo, a transferência de arquivos através de um protocolo específico, como Wi-Fi Direct. Desta maneira, o propósito principal do ambiente de execução é executar e controlar as interações definidas em uma especificação de ambiente inteligente feita na linguagem de especificação. Todos os requerimentos tecnológicos apresentados nesta seção têm exclusivamente esse propósito.

Especificamente, o ambiente de execução não tem como propósito ser um arcabouço para construção de agentes que seguem o modelo proposto. O ambiente de execução disponibiliza uma API que tem como objetivo permitir outros artefatos de software (agentes) fazer parte de interações definidas no ambiente. Conforme definido no modelo conceitual, agentes podem ser construídos com tecnologias específicas com o único requerimento de conseguir fazer parte de interações definidas no ambiente.

O ambiente de execução dá suporte a diferentes aspectos tecnológicos para a execução de interações. Este suporte é fornecido por diferentes camadas, com o propósito de usar diferentes tecnologias na sua implementação. Por exemplo, frente a necessidade de replicar informação em todos os dispositivos do ambiente, a camada de serviços pode implementar protocolos para redes ponto-a-ponto para manter informação consistente de maneira eficiente considerando a mobilidade dos dispositivo. Os serviços implementados neste protótipo do ambiente de execução foram implementados de maneira simples e pouco eficiente, atualizando informação de um ponto em todos os outros toda vez que acontece alguma atualização. 


\section{Capítulo 5}

\section{Exemplos de uso}

Neste capítulo apresentamos exemplos de uso do modelo proposto. Inicialmente apontamos como o modelo proposto pode ser usado para reconstruir aspectos relevantes dos sistemas apresentados no Capítulo 2.

\subsection{Grupos de projetos focados em ambientes inteligentes}

Agrupamos os projetos do Capítulo 2 em três grupos que apresentam características comuns na abordagem de construir e ativar ambientes inteligentes.

\subsubsection{Grupo 1: Projetos focados no desenvolvimento de plataformas}

Estes projetos apoiam a construção de um ambiente inteligente dando o suporte necessário para a implementação de entidades do ambiente, sendo que estas entidades do ambiente são vistas como artefatos de software. A construção de um ambiente inteligente é uma tarefa programática.

Este suporte é fornecido em duas maneiras: (1) através de uma plataforma para a execução de entidades do ambiente inteligente, e (2) através de arcabouço que oferece um modelo de programação para construção dessas entidades.

Projetos neste grupo são: (1) OSAmI - Open Source Ambient Intelligence, (2) Projeto PERSONA - PERceptive Spaces prOmoting iNdependent Aging e (3) GAIA. Este grupo é caracterizado por:

1. o desenvolvimento de artefatos de software usando a API da plataforma para desenvolver todas suas funcionalidades;

2. a plataforma fornecer mecanismos para a detecção de eventos e compartilhamento de informação de contexto;

3. um ambiente de execução homogêneo para a execução destes artefatos de software;

4. a ativação de interações contextualizadas entre artefatos através de chamadas programáticas.

A comunicação entre componentes de software é definida na implementação dos componentes em hard-code como chamadas remotas de procedimentos (RPC - Remote Procedure Call). Na visão destes projetos, um ambiente inteligente é um fornecedor de serviços através de uma plataforma que muda seu comportamento dinamicamente segundo o contexto físico e computacional de dispositivos e os próprios artefatos de software. Especificamente, o projeto OSAmI define dois atores principais: fornecedores de serviços e consumidores de serviços. 


\subsubsection{Grupo 2: Projetos baseados em interações de entidades inteligentes}

Este grupo de ambientes inteligentes desenvolve um conjunto de aplicações e dispositivos inteligentes com o objetivo de oferecer funcionalidades relevantes para pessoas dentro dos ambientes. Estas funcionalidades são construídas através de interações entre aplicações e dispositivos ou individualmente por estes. Estas interações são baseadas em informação de contexto e preferências das pessoas. Este grupo é caracterizado por:

1. diferentes aplicações e dispositivos inteligentes em um espaço físico interagirem coordenadamente;

2. interações contextualizadas ocorrerem segundo o estado das entidades no ambiente;

3. possuírem um mecanismo para modelagem e processamento de informação de contexto.

Neste grupo se encontram os seguintes projetos: (1) Gator-Tech Smart House, (2) BlueSpace IBM, (3) Fluid Interfaces - MIT (este projeto também se encontra no grupo de projetos focados na percepção de humanos), e (4) Usable Smart Environments - FX Palo Alto Laboratory Inc.

$\mathrm{Na}$ visão destes projetos, os mecanismos de coordenação entre entidades inteligentes é altamente configurável e dinâmico, considerando que as interações entre estas entidades possam mudar segundo o domínio de aplicação e preferências dos usuários.

Estes projetos focam em domínios específicos de aplicação, como é o caso do Gator-Tech, focado em smarthouses, e o BlueSpace, focado em estações de trabalho de escritórios.

\subsubsection{Grupo 3: Projetos focados na percepção de humanos}

Este grupo de projetos segue a linha da computação ubíqua no que se refere a objetos no diaa-dia das pessoas serem usados para interagir com sistemas computacionais, focando em melhorar a percepção que pessoas tem do ambiente inteligente.

Estes projetos buscam melhorar esta percepção através da criação de dispositivos embutidos em objetos comuns, de maneira que interações surjam de maneira intuitiva para as pessoas. Este grupo está caracterizado por:

1. dispositivos embutidos no ambiente segundo os princípios da computação ubíqua;

2. dispositivos carregados por pessoas usados em diferentes espaços físicos;

3. interfaces inovadoras focadas em melhorar a percepção de ambientes por pessoas.

Projetos neste grupo são: (1) Experience Lab - Phillips, (2) Fluid Interfaces - MIT, (3) Ambient Intelligence Research Lab - Stanford e (4) Smart Environment Group - SERG - Ulster University.

\subsection{Caso de Estudo: Um ambiente inteligente para o IME}

Nesta seção apresentamos um ambiente inteligente concreto. Este ambiente inteligente pode ser especificado e ativado usando o modelo apresentado nos capítulos anteriores e mostra diferentes características do modelo.

Apresentamos um ambiente inteligente para o IME (Instituto de Matemática e Estatística - USP) considerando os cenários a seguir. É pressuposto que pessoas carreguem algum tipo de dispositivo que permita determinar sua localização. Tipicamente, consideramos que estas pessoas carreguem um smartphone.

1. Toda vez que uma pessoa entra em algum bloco, andar ou sala do IME, são apresentadas informações sobre eventos a serem realizados no ambiente que entrou. Estes eventos são de interesse público para estudantes do IME, como palestras, seminários e defesas, e podem ser privados como reuniões e disciplinas. 
2. Pessoas em diferentes ambientes do IME podem disponibilizar sua localização. Isto é permitido por áreas simbólicas que compartilham a localização das entidades localizadas dentro dela. Este compartilhamento é baseado em restrições sobre interações.

3. Pessoas podem imprimir arquivos em impressoras localizadas em diferentes salas, e também podem apresentar arquivos (no formato adequado) em projetores nas salas que se encontram instalados.

4. É apresentado no smartphone da pessoa informações sobre o espaço físico do IME em que se encontram. Por exemplo, quando um aluno acessa o bloco B, são mostradas as salas onde serão dadas as disciplinas em que o aluno está matriculado. Isto é de especial interesse para alunos ingressantes no IME.

5. O sub-ambiente inteligente do auditório Antônio Gilioli fornece suporte para palestrantes, permitindo compartilhar arquivos do palestrante com participantes da palestra, e também permite ao palestrante apresentar slides através do projetor na sala.

6. É possível acessar informações do sistema corporativo Janus com o propósito de obter informação sobre alunos, disciplinas, professores, salas etc. e também é possível acessar o sistema da biblioteca para efetuar reservas e consultas de empréstimos de livros.

Estes cenários são implementados através dos agentes e serviços definidos a seguir, e pela especificação das interações entre estes. É suposto que estes agentes são hospedados no smarthome carregado por uma pessoa e os serviços são executados em dispositivos fixos, que são conhecidos como servidores do ambiente, e podem ser acessados de qualquer agente ou serviço independentemente da sua localização.

AmICalendar: agente que coleta eventos pessoais e publicados do IME, para notificar no dispositivo que hospeda o agente.

AmILocator: agente que permite compartilhar a localização das pessoas através do smartphone que hospeda o agente. Adota dois papéis: amilocator e amilocatormanager.

AmIFileShared: agente que compartilha arquivos com dispositivos específicos, como impressoras e projetores. Adota os seguintes papéis: amifileshared, amiviewer e amispeaker.

AmIWelcome: agente que fornece informação contextualizada segundo a localização dentro do IME. Adota os papéis amiwelcome e amiwelcomeserver.

AmIIME: agente que interage com outros serviços e agentes de maneira autônoma e inteligente com o propósito de cumprir metas estabelecidas pelas pessoas.

SIMECalendar: serviço de agendamento e notificação de eventos públicos que acontecem no IME.

SIMELibrary: serviço de empréstimo e consulta de livros.

SIMEJanus: serviço que acessa no sistema corporativo Janus.

\section{Agente AmICalendar e serviço SIMECalendar}

O agente AmICalendar e o serviço SIMECalendar trabalham conjuntamente para informar às pessoas que se movimentam dentro de uma sala do IME sobre eventos registrados nesse ambiente. O registro de eventos novos é feito no serviço SIMECalendar por pessoas com autorização adequada. Também é possível que pessoas registrem eventos pessoais no agente AmICalendar. O agente AmlCalendar se encarrega de consultar o serviço SIMECalendar por novos eventos segundo a localização do dispositivo associado. 
Como exemplo deste cenário, definimos que quando um aluno entra no bloco B recebe no seu smartphone a lista de seminários a serem apresentados no auditório Gilioli durante o dia. Também, a partir do registro de um evento pessoal (por exemplo, a reunião com um professor), ele é notificado desta reunião. Este cenário é também usado para notificar a lista de disciplinas que serão ministradas em uma sala de aula específica.

\section{Agente AmILocator}

Este agente adota dois papéis: (1) o papel amilocator que representa as funcionalidades do próprio agente, e (2) o papel amilocatormanager que representa agentes AmILocator associados a diferentes áreas simbólicas e que se encarrega de registrar e compartilhar a localização de outros agentes AmlLocator.

Este agente, no papel de amilocator, notifica a localização do dispositivo em que se encontra hospedado. Se este dispositivo for sempre carregado por uma pessoa, este indica a posição de uma pessoa. Este agente registra sua localização para agentes AmlLocator que adotam o papel amilocatormanager. Este registro é definido por uma regra de interação associada na área simbólica em que se encontram os agentes. Para um espaço físico do IME compartilhar a localização, é necessário que ele possua esta regra de interação.

É necessário notar que o agente que adota o papel amilocatormanager deve armazenar um registro único sobre a localização dos agentes. Consideramos que este agente é executado em um dispositivo fixo associado à área simbólica.

No escopo de interação deste agente é informado o conjunto de agentes com os quais está permitido interagir, desta maneira o agente AmlLocator compartilha sua localização somente quando se encontra em espaços físicos específicos.

\section{Agente AmIFileShared}

Este agente permite compartilhar arquivos com outros agentes e, portanto, com dispositivos associados. Entre estes dispositivos se encontram impressoras e projetores localizados em diferentes salas do IME. Este agente esta associado aos seguintes dispositivos: (1) a impressora Orca da sala das Estações de Trabalho (sala 147A), (2) a impressora Esquadro localizada no bloco B, e (3) e o projetor localizado no auditório Gilioli, localizado no bloco A.

Neste cenário, quando uma pessoa se localiza nestas salas, é ativada a interação entre o dispositivo carregado pela pessoa e a impressora ou o projetor, ativando a impressão de arquivos ou a apresentação de slides. No caso da impressão, é necessário que a pessoa se localize fisicamente na sala da impressora. Esta interação pode não ser muito útil quando surgir a necessidade de imprimir um documento de qualquer sala do IME, por isso é possível definir outra regra de interação que permita imprimir de qualquer área simbólica do IME. Por outro lado, a interação com o projetor requer que a pessoa se localize na mesma sala do projetos no momento da palestra.

A transferência e recepção de arquivos é ativada por agentes AmlFileShared que adotam os papéis amifileshared. Já o papel amiviewer permite a recepção de arquivos para encaminhá-los para o dispositivo adequado (impressora ou projetor). Este agente no papel amispeaker permite a um palestrante apresentar slides no projetor e enviar informações relevantes a participantes da palestra.

\section{Agente AmIWelcome}

O agente AmIWelcome no papel amiwelcome interage com outros agentes do mesmo tipo que adotam o papel amiwelcomeserver. Este agente permite obter informação relevante segundo a localização (alguma sala dentro do IME) do dispositivo em que é executado. São consideradas as seguintes informações: (1) conforme o agente se movimenta no IME é apresentada informação sobre o espaço físico em que se encontra, e (2) horários e local das disciplinas em que o proprietário do dispositivo está matriculado. Como exemplo da primeira funcionalidade é definido que quando a pessoa (e, portanto, o dispositivo) se localiza no ambiente da biblioteca são apresentados os horários 
de funcionamento e o regulamento sobre empréstimo de livros. Para a implementação da segunda funcionalidade é definida a interação como serviço SIMEJanus que permite extrair essas informações.

A apresentação de informação em cada área simbólica é definida através de uma regra de interação (que é executada quando o agente entra na área simbólica associada) e um agente que adota o papel amiwelcomeserver dentro dessa área simbólica. Desta maneira, existem diferentes implementações do agente AmIWelcome segundo a informação a ser apresentada de cada área simbólica. No exemplo, o agente da biblioteca tem uma implementação que fornece a informação descrita anteriormente. Embora existam diferentes implementações deste agente, todos estes fornecem o mesmo comportamento, dado que podem adotar o papel amiwelcomeserver.

Neste cenário, os serviços SIMEJanus e SIMELibrary se mostram úteis para estas interações. Desta maneira, podem ser implementados serviços com propósitos específicos, como um serviço para informações de pós-graduação.

\section{Agente AmlIME}

Este é um agente autônomo que possui o modelo de inteligência BDI (Belief-Desire-Intention model [BHW07]), e pode adotar qualquer papel de agentes definidos anteriormente. O próprio agente decide quando adotar, isto segundo as preferências da pessoa proprietária do agente ou por decisão do agente tentando satisfazer sua meta. Para a implementação deste agente foi feita a integração do modelo com Jason, como é apresentado nas seguintes seções.

Como exemplo, é definido que este agente adota o papel amicalendar, detecta que o usuário é o palestrante de um seminário no mesmo dia, e de maneira automática este agente adota o papel amispeaker do agente AmIFileShared no momento da palestra para apresentar as slides adequados no auditório Gilioli. Também é apresentado que este agente adota as funcionalidades do agente AmIWelcome para obter informação sobre livros emprestados segundo a lista de disciplinas matriculadas.

Note-se que este agente decide de maneira autônoma o interesse por adotar algum papel, e não o inicio da interação. Assim, este agente demonstra como agentes autônomos fazem parte do ambiente inteligente através de interações já definidas em áreas simbólicas.

\subsection{Especificação e implementação do caso de estudo}

Nesta seção apresentamos aspectos importantes da implementação do ambiente de execução e dos agentes introduzidos no caso de estudo. Desde que o foco dos experimentos não é a construção de agentes para ativar o ambiente inteligente definido no caso de estudo, a implementação dos agentes é feita empregando o suporte fornecido pelos serviços do ambiente de execução ou usando funcionalidades do sistema operacional, como é o caso do agente AmIFileShared que imprime um documento através de comandos do Linux.

O ambiente de execução foi implementado na linguagem Java com o propósito de ser executado em dispositivos móveis e fixos com suporte para a máquina virtual Java 1.6 ou superior e para a plataforma Android 2.3 ou superior ${ }^{1}$.

O código fonte da implementação do ambiente de execução e dos agentes do caso de estudo está disponibilizado no seguinte endereço: http://code.google.com/p/amimodel/, com o nome de projeto AmIModel. Também está disponível o interpretador da linguagem de especificação, sendo que este foi criado a partir do código fonte do interpretador LCC disponibilizado pelo projeto OpenKnowledge para o professor Flávio Soares Corrêa da Silva.

\subsubsection{Módulos do ambiente de execução e infraestrutura de comunicação}

Na Figura 5.1 se apresentam os principais módulos do ambiente de execução. O componente AmIModelCore contém os serviços do ambiente de execução apresentados na Subseção 4.3.2. A ca-

\footnotetext{
${ }^{1}$ http://developer.android.com
} 
mada de infraestrutura e comunicação é implementada como um agente do arcabouço Jade [BCG07] que ativa a comunicação ponto-a-ponto entre diferentes dispositivos, incluindo dispositivos móveis que executam Android ${ }^{2}$.

No componente AmIModelCore se encontram implementados os mecanismos de descoberta e execução de regras de interação apresentadas na Subseção 4.1.9. Este componente recebe eventos físicos e computacionais e os encaminha para os AgentBase interessados nesses eventos, como descrito na Subseção 4.1.7.

Os componentes AgentBase são componentes através do quais implementações de agentes interagem com o ambiente de execução. Mantendo os princípios de organizações de agentes como sociedades semi-fechadas, toda interação é somente através deste componente. Desta maneira, implementações de agentes são obrigados a criar uma instância do componente AgentBase para fazer parte do modelo de ambiente inteligente. Componentes AgentBase são criados a partir do componente AmIModelCore.

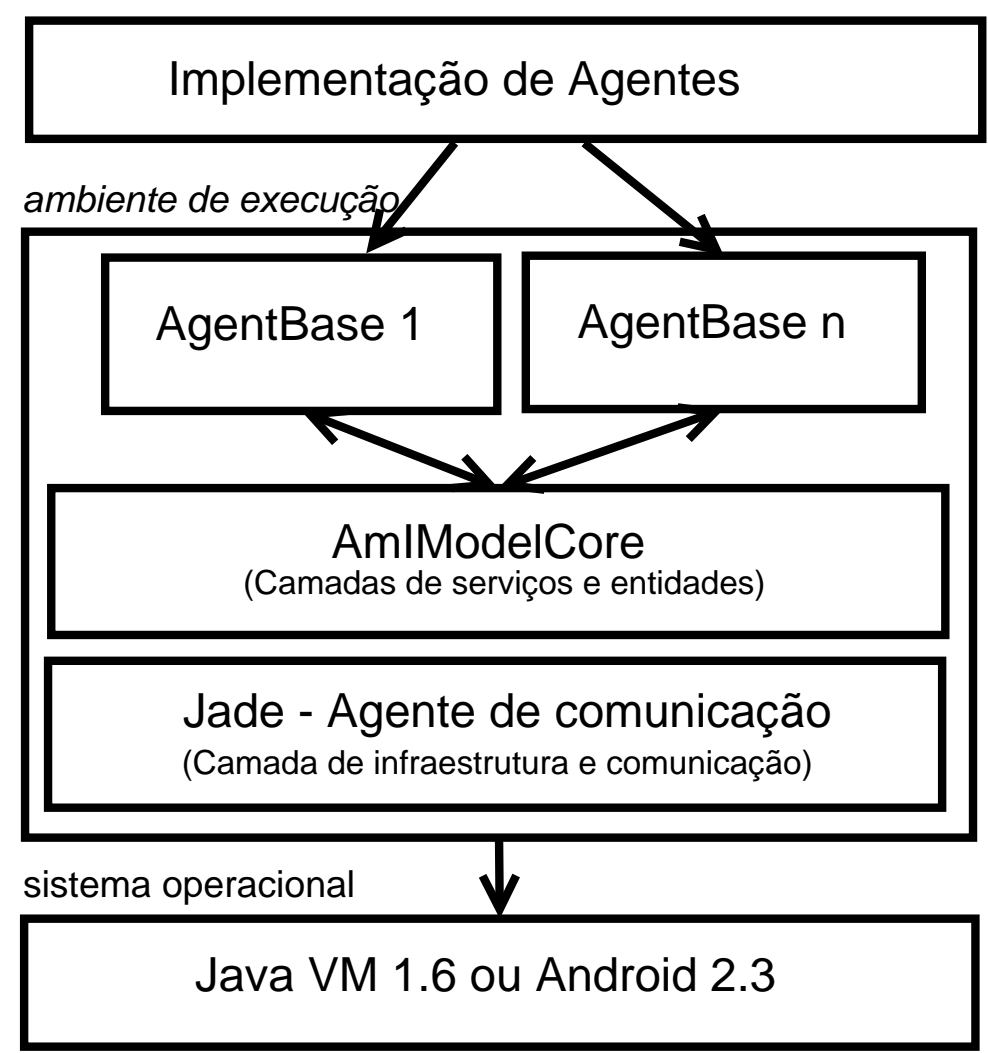

Figura 5.1: Módulos do ambiente de execução.

\subsubsection{Localização de dispositivos}

Usamos o MoCA para ativar a localização de dispositivos a partir de pontos de acesso Wi-Fi (padrão IEEE 802.11). Este middleware já foi usado satisfatoriamente no trabalho de mestrado do proponente [Nor07]. Além da localização de dispositivos, usamos o MoCA para coletar informação sobre porcentagem de uso de CPU e memória RAM livre do dispositivo.

Também, o MoCA permite a divisão de espaços físicos em áreas simbólicas e a partir da potência do sinal de pontos de acesso visíveis pelo dispositivo é possível determinar a área simbólica em que um dispositivo se encontra. O serviço de localização do MoCA possui precisão de metros para determinar a localização dos dispositivos. Como as áreas simbólicas definidas são consideravelmente grandes, esta margem de precisão é adequada para os experimentos realizados.

\footnotetext{
${ }^{2}$ http://jade.tilab.com/doc/tutorials/JadeAndroid-Programming-Tutorial.pdf
} 
Nos experimentos realizados simulamos o comportamento do MoCA através da implementação das interfaces apresentadas no Código 5.1. A interface LocationInferenceListenerInterface representa o serviço de localização de dispositivos. Objetos interessados na localização de dispositivos registram um objeto listener (que implementa a interface DeviceListener da linha 11) nesse serviço através do método subscribe. O parâmetro mac representa um identificador único do dispositivo, tipicamente é considerado o endereço MAC da interface de rede Wi-Fi (linha 6).

Toda vez que o dispositivo se movimenta dentro de uma área simbólica é chamado o método onRegionChanged do listener, passando como parâmetros o identificador do dispositivo e o nome desta área simbólica.

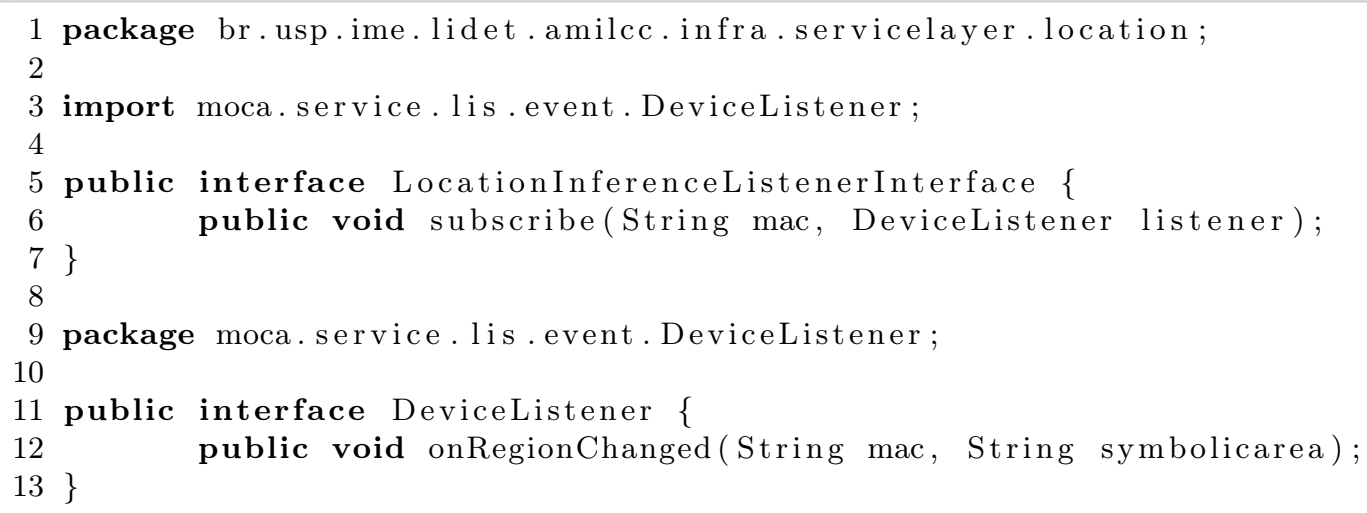

Código 5.1: Interfaces de localização do ambiente de execução.

Note-se que a facilidade de uso do mecanismo de localização permite implementar o serviço de localização de maneira desacoplada da implementação do ambiente de execução. A manipulação de áreas simbólicas através de nomes de áreas simbólicas facilita a inferência lógica usada na informação de contexto e eventos.

\subsubsection{Definições declarativas de agentes e áreas simbólicas}

Conforme apresentado na Seção 4.2, a linguagem de especificação do modelo permite definir diferentes entidades de um ambiente inteligente como: áreas simbólicas, regras de interação e agentes. O ambiente de execução permite a criação destas entidades a partir destas declarações no momento que um agente se registra nele. Estas declarações são disponibilizadas através do serviço RepositoreService, o qual disponibiliza estas declarações no ambiente de execução.

O Código 5.2 apresenta a definição de agentes no caso de estudo apresentado na Seção 5.2

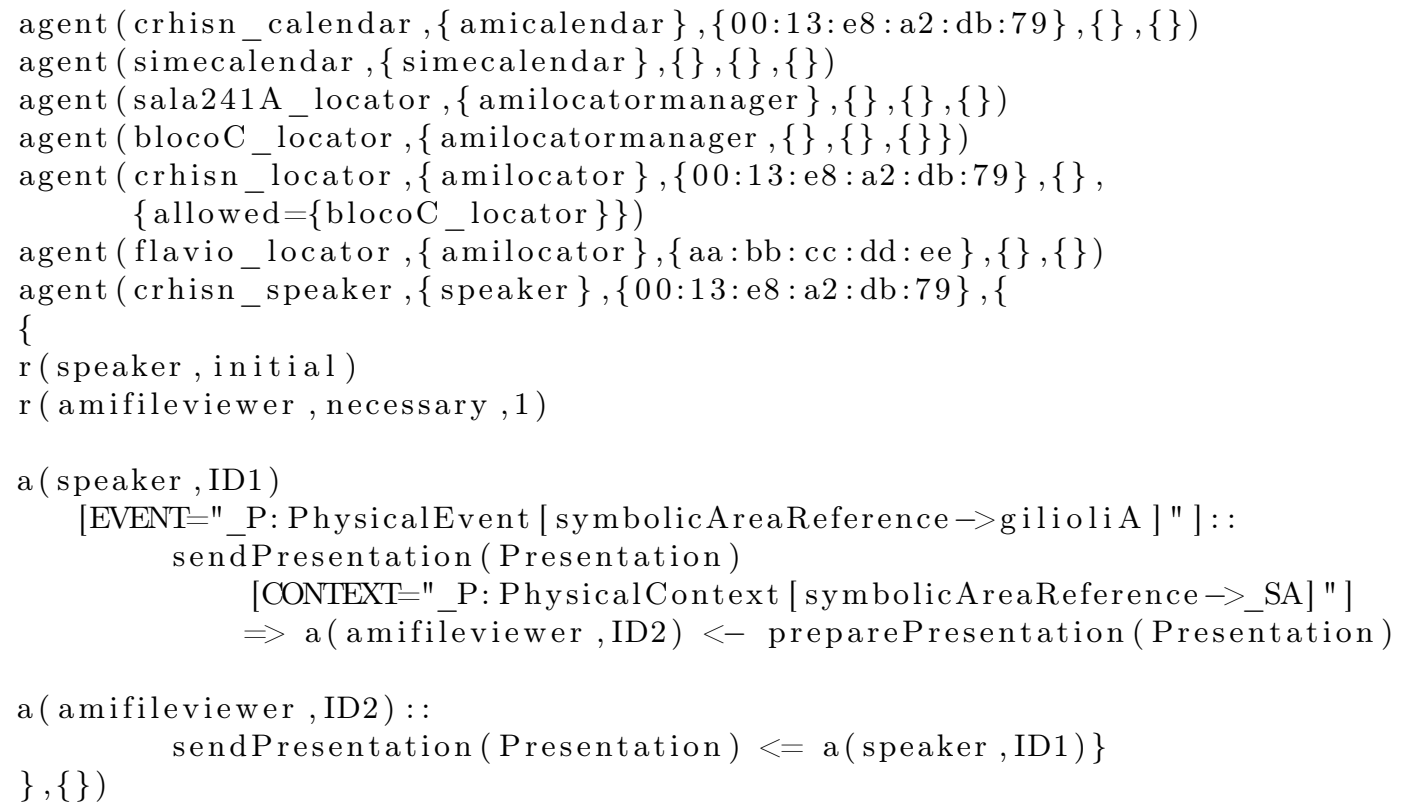




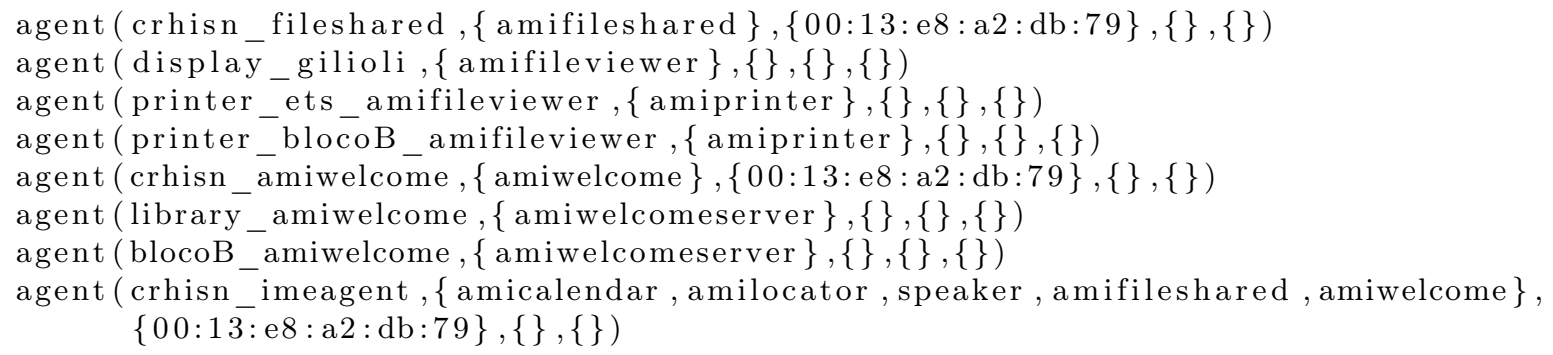

Código 5.2: Definição de agentes do IME.

No Apêndice B.1 se apresentam as declarações de áreas simbólicas e regras de interação definidas para ativar o ambiente inteligente do IME.

Note-se que, no caso de agentes, este mecanismo somente cria componentes AgentBase que permitem a componentes de software (agentes externos) interagir com o ambiente de execução. A criação destes componentes é solicitada por componentes de software que desejam fazer parte do ambiente inteligente. A criação de componentes AgentBase desde declarações permite sua criação em diferentes dispositivos, possibilitando fazer parte do ambiente inteligente dinamicamente. É necessário notar que isto não ativa a mobilidade de agentes entre dispositivos, pois não é transferido o estado computacional entre componentes AgentBase criados.

\subsubsection{Ontologia da linguagem para o caso de estudo}

A ontologia da linguagem apresentada na Subseção 4.2.3 pode ser extendida com conceitos e axiomas próprios do domínio de aplicação do ambiente inteligente, bem como com axiomas necessários para a inferência de informação de contexto. Neste sentido, o axioma do Código 5.3, nas linhas 1-7, permite inferir o fato que dispositivos localizados dentro de sub-áreas também estão localizados na área que contém á sub-área. Por exemplo, um dispositivo localizado no auditório Gilioli também está localizado dentro do bloco A.

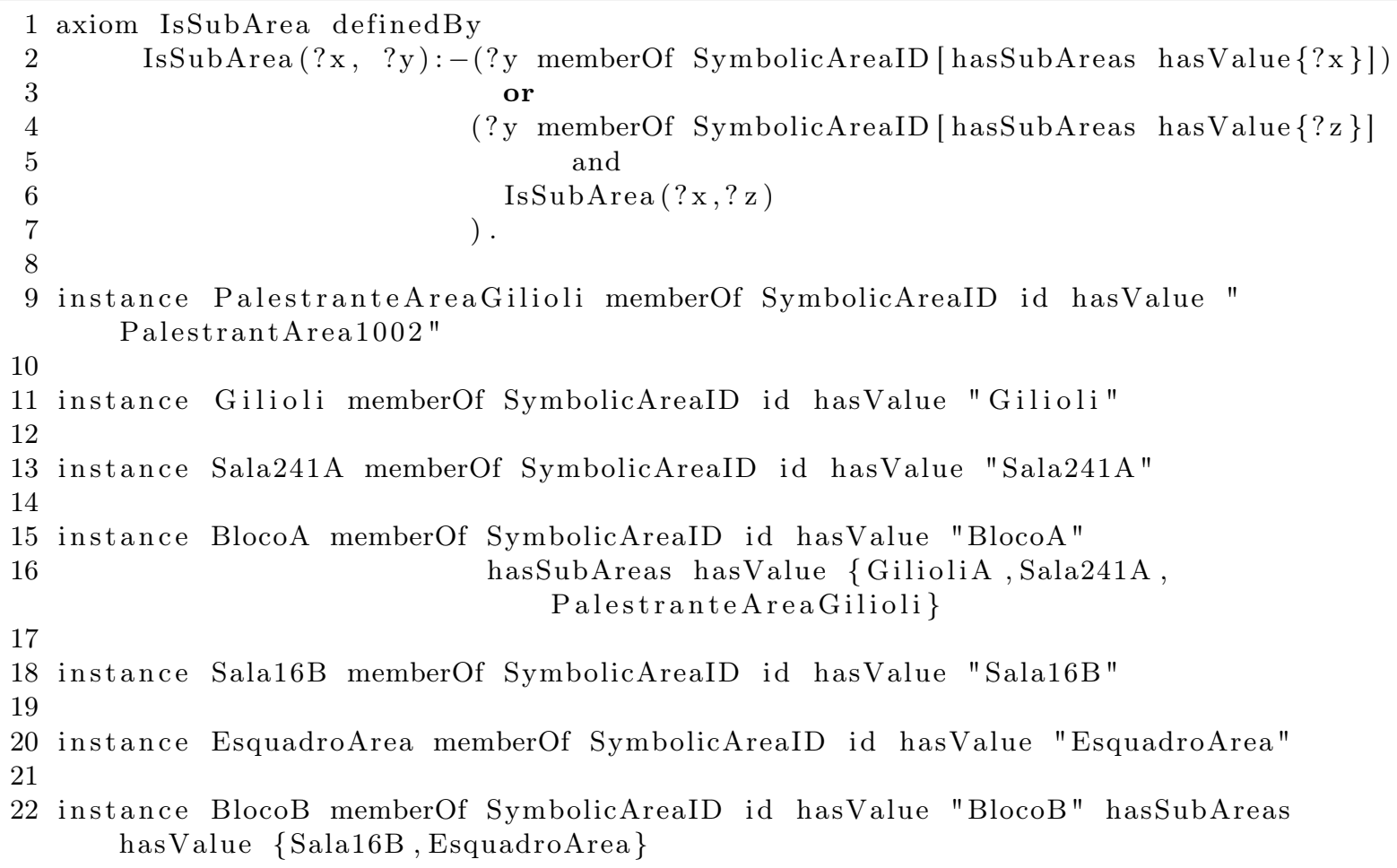

Código 5.3: Axioma para a definição de sub-áreas de áreas.

Neste ponto, é definida a estrutura de áreas simbólicas do caso de estudo como instâncias dos conceitos da ontologia, como mostram as linhas 9 a 22 no Código 5.3. 
Por outro lado, o calçamento entre as informações de contexto do agente e do contexto definido no papel da regra de interação segue o mecanismo apresentado na Subseção 4.2.3, que requer que um agente satisfaça a consequência lógica da seguinte equação:

$$
\text { Ontologia } \wedge K B_{\text {agente }} \vdash \text { Papel }_{\text {contexto }}
$$

Neste ponto, foram implementados mecanismos para converter objetos Java em instâncias de conceitos em F-Logic. Estes objetos Java contêm a informação de contexto corrente do agente em tempo de execução. Esta conversão é direta pelas similaridades Classes-Conceito e CamposAtributos entre OO (Orientação a Objetos) e $t F$-Logic. No Código 5.4 se mostra o caso de informação de contexto do mundo físico (PhysicalContext).

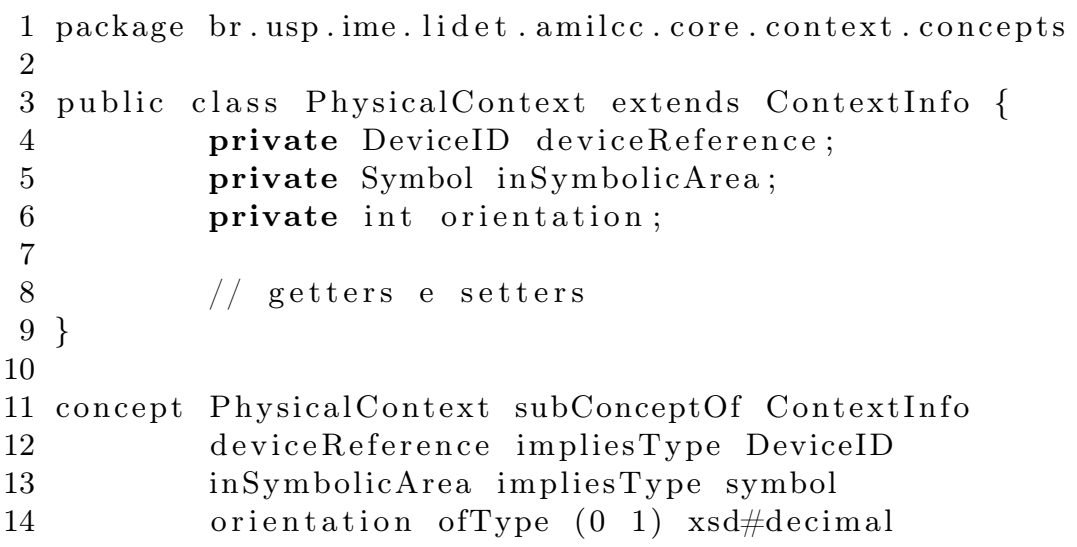

Código 5.4: Mapeamento entre objetos Java e conceitos F-Logic.

\subsubsection{Processamento de mensagens e restrições na execução de regras de inter- ação}

As mensagens e restrições definidas nas regras de interação correspondem a rotinas implementadas em uma linguagem de programação. Na implementação dos agentes estas rotinas correspondem a métodos de objetos Java que são executados segundo o protocolo de comunicação descrito na regra de interação.

Note-se que um agente que deseje adotar um papel se compromete a implementar os métodos definidos nas mensagens e restrições associados a este papel, como parte do agente implementar o comportamento definido pelo papel. O ambiente de execução é o encarregado de executar estes métodos na execução de regras de interação.

O mapeamento entre mensagens e restrições com métodos é feito através de reflexão e anotações da linguagem Java. Os métodos Java devem ser marcados com a anotação @AmllnteractionMethod que recebe no atributo predicateName o nome da mensagem ou restrição associada, como se mostra no Código 5.5. Estes métodos devem possuir a assinatura apresentada na linha 8 para o processamento de mensagens, e a assinatura da linha 2 para o processamento de restrições. Adicionalmente, pode ser informado no atributo arguments da anotação @AmllnteractionMethod a lista de argumentos (da mensagem ou restrição) associados em caso de ambigüidade, como se mostra na linha 13.

$1 @$ AmIInteractionMethod (predicateName = "requestUserID" )

2 public void requestUserID(LCCConstraint constraint, String name,

$3 \quad$ Vector $<$ LCCArgument $>$ args $)\{$

$4\}$

$6 @$ AmIInteractionMethod (predicateName = "response")

7 public void response(LCCMessage message, String name,

8

10

$11 @$ AmIInteractionMethod (arguments $=\{$ "Events" $\})$ 
12 public void processReply(LCCConstraint constraint, String name,

$13 \quad$ Vector $<$ LCCArgument $>$ args ) \{

$14\}$

Código 5.5: Assinatura de métodos Java para chamadas de mensagens e restrições nas regras de interação.

O Código 5.6 apresenta a regra de interação mapeada pelo Código 5.5. Desta forma, a implementação de um agente que deseja adotar um papel requer a implementação dos métodos Java associadas ao papel. No exemplo, o agente que adota o papel amicalendar requer a implementação dos métodos requestUserID, response e processReply. A mensagem eventsForSymbolicAreaUser é uma mensagem de saída criada e entregue pelo ambiente de execução a partir da restrição requestUserID e não requer nenhum método Java para seu processamento.

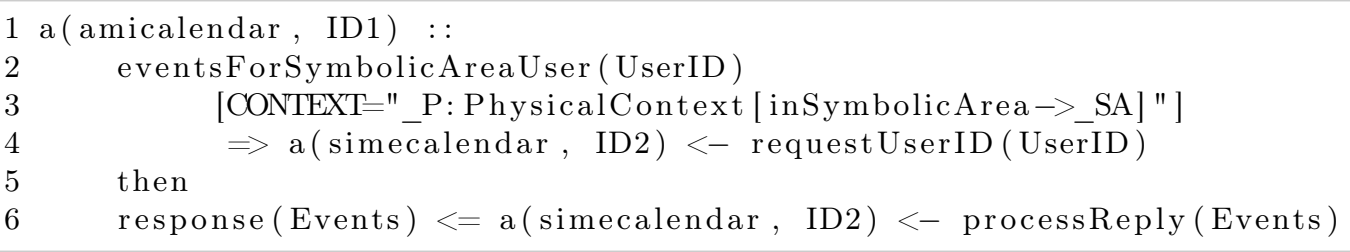

Código 5.6: Exemplo de regra de interação mapeada a métodos Java.

\subsubsection{Implementação dos agentes do caso de estudo}

Nesta seção mostramos os pontos chave na implementação dos agentes e serviços do caso de estudo. Também apresentamos as interfaces de usuário destes agentes e serviços.

Conforme foi descrito, o serviço SIMECalendar disponibiliza um interface Web para o cadastro de eventos que aconteceram no IME. A Figura 5.2 mostra a tela principal desta interface. É cadastrado o nome, data e hora, local e descrição do evento. O local do evento se refere à área simbólica onde acontecerá o evento. No exemplo, são registrados dois eventos para o espaço físico gilioliA, que se refere ao auditório Gilioli do IME.

Mónbox-crhisnoriega@gmail... $x$ New Tab
Back Forward Olocalhost:9090/sime
SIMECalendar GUI

File

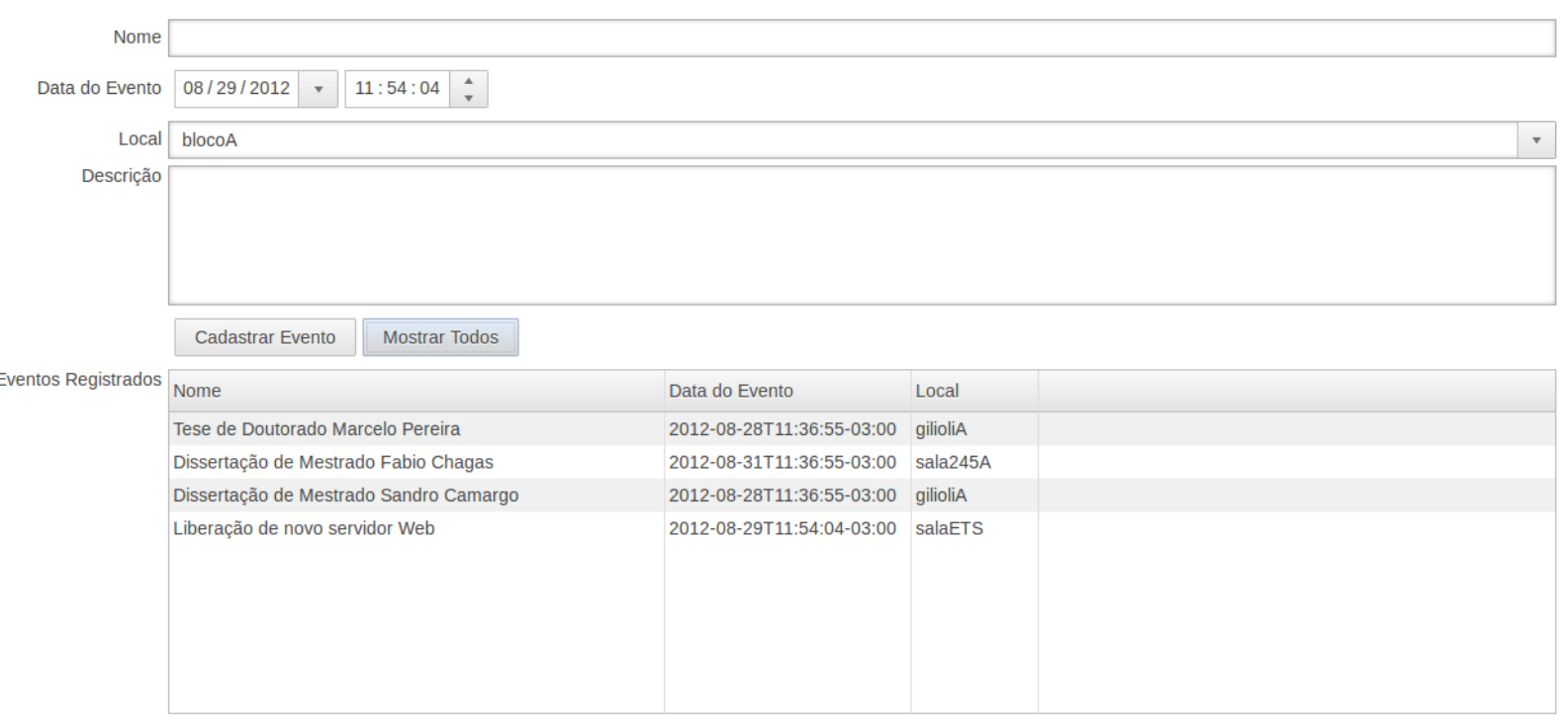

Figura 5.2: Interface Web do serviço SIMECalendar para cadastro de eventos públicos. 
As Figuras 5.3 e 5.4 mostram a interface do agente AmICalendar. Através destas telas um usuário é notificado com os eventos que aconteceram no espaço físico em que está localizado. A área simbólica em que se localiza se mostra na parte Eventos por Localização.

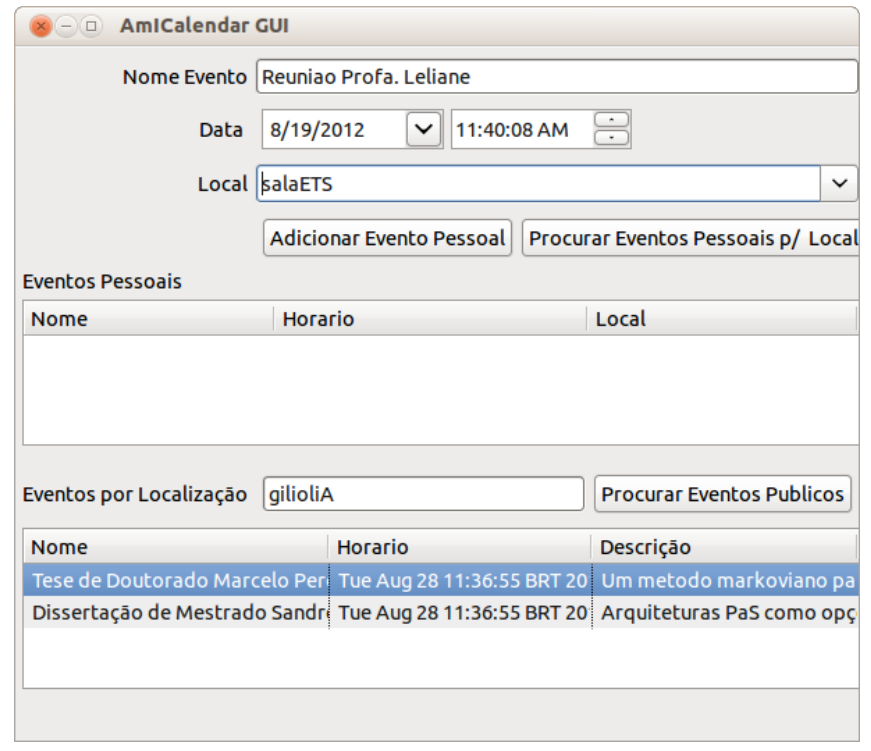

Figura 5.3: Interface do usuário do agente Am/Calendar para notificação de eventos públicos.

Dependendo da localização, são apresentados eventos pessoais (anteriormente registrados) que irão acontecer na área simbólica localizada. Na Figura 5.4, o evento Reunião Profa. Leliane é mostrado.

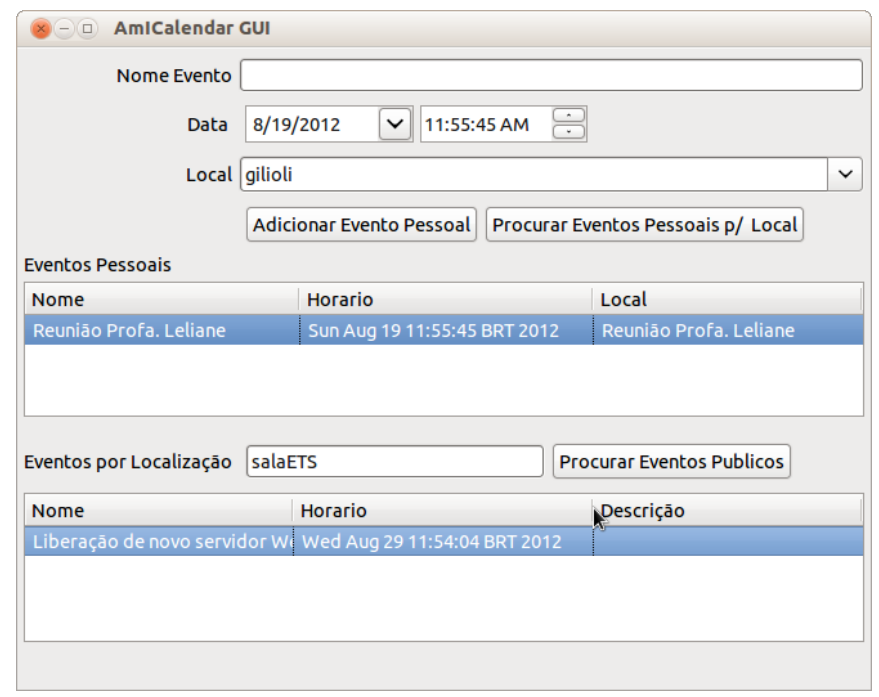

Figura 5.4: Interface do usuário do agente Am/Calendar para o registro e notificação de eventos pessoais.

No Código 5.7 se mostra a declaração de três agentes AmlLocator -neste cenário, toda vez que o agente crhisn_locator se movimenta dentro do bloco C do IME é executada a regra de interação do Código 5.8 que permite ao agente se registrar com o agente blocoC_locator. Desta forma, o agente blocoC_locator mantém um registro da localização do agente crhisn_locator, e outros agentes, nesta área simbólica. 


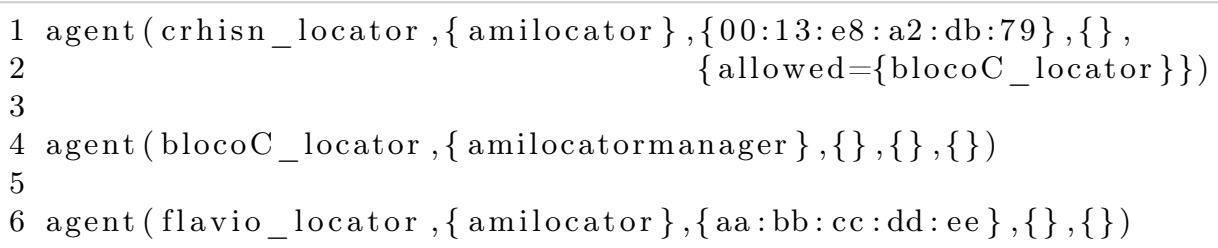

Código 5.7: Declaração dos agentes AmILocator no caso de uso.

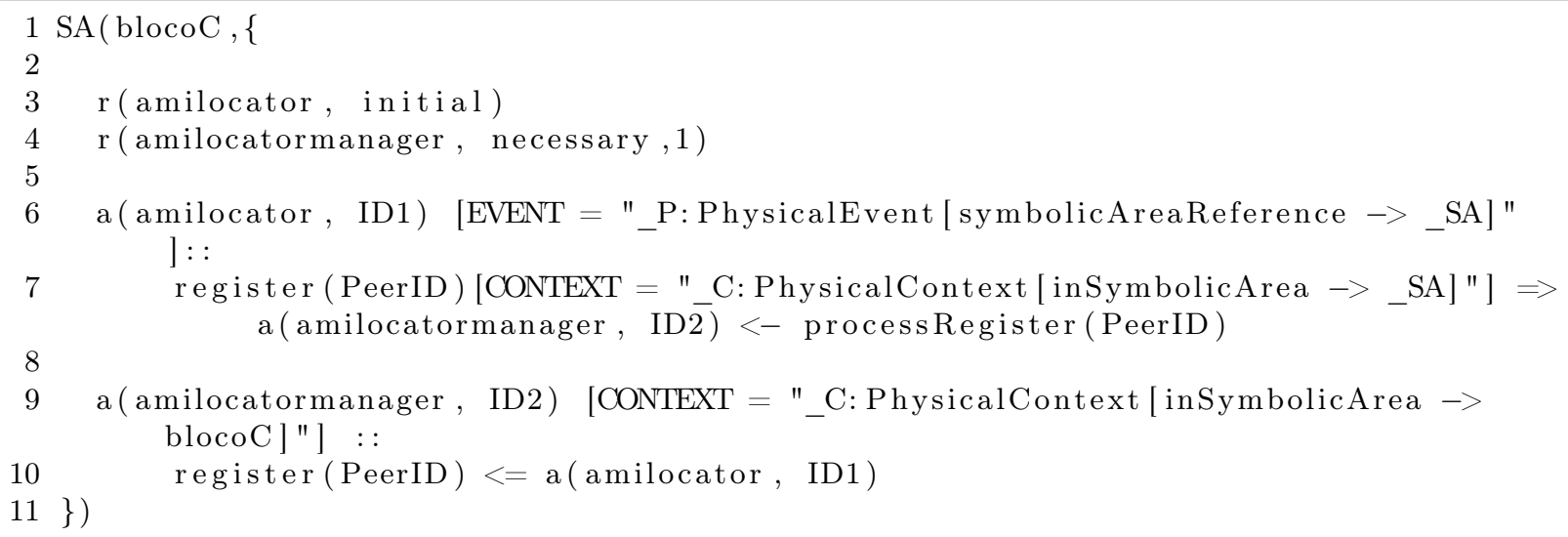

Código 5.8: Regra de interação para o registro de agentes que entra na área simbólica blocoC

Outros agentes podem consultar a localização de agentes através da regra de interação do Código 5.9 que é iniciada através da tela mostrada na Figura 5.5. Nesta figura, o agente flavio_locator consulta a localização do agente crhisn_locator. Note-se que esta regra de interação não estabelece nenhuma localização para os agentes, e se encontra disponível na área simbólica blocoC.

Um ponto importante neste exemplo é o associação de uma regra de interação com a meta de um agente. Quando é clicado o botão Procurar da interface do usuário, é feita uma busca na área simbólica pela regra de interação que permita obter o resultado desejado, representado pela meta C:PhysicalContext[inSymbolicArea ->_SA, deviceReference ->_PeerID]. Esta meta define que se obterá como resultado um estado de contexto com uma área simbólica (representado pelo atributo inSymbolicArea) e um identificador de dispositivo (representado pelo atributo deviceReference).

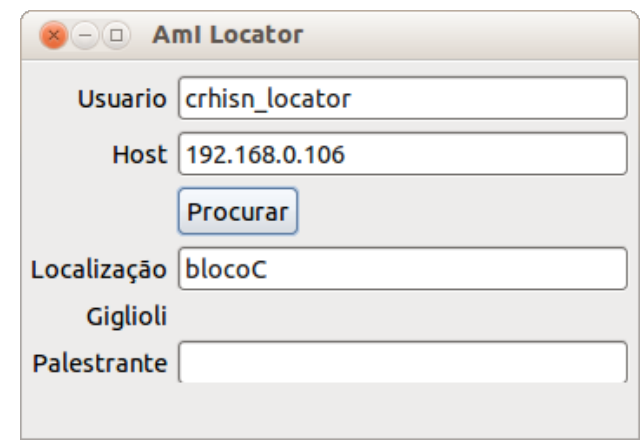

Figura 5.5: Interface de usuário do agente AmILocator para consulta da localização de outros agentes. 


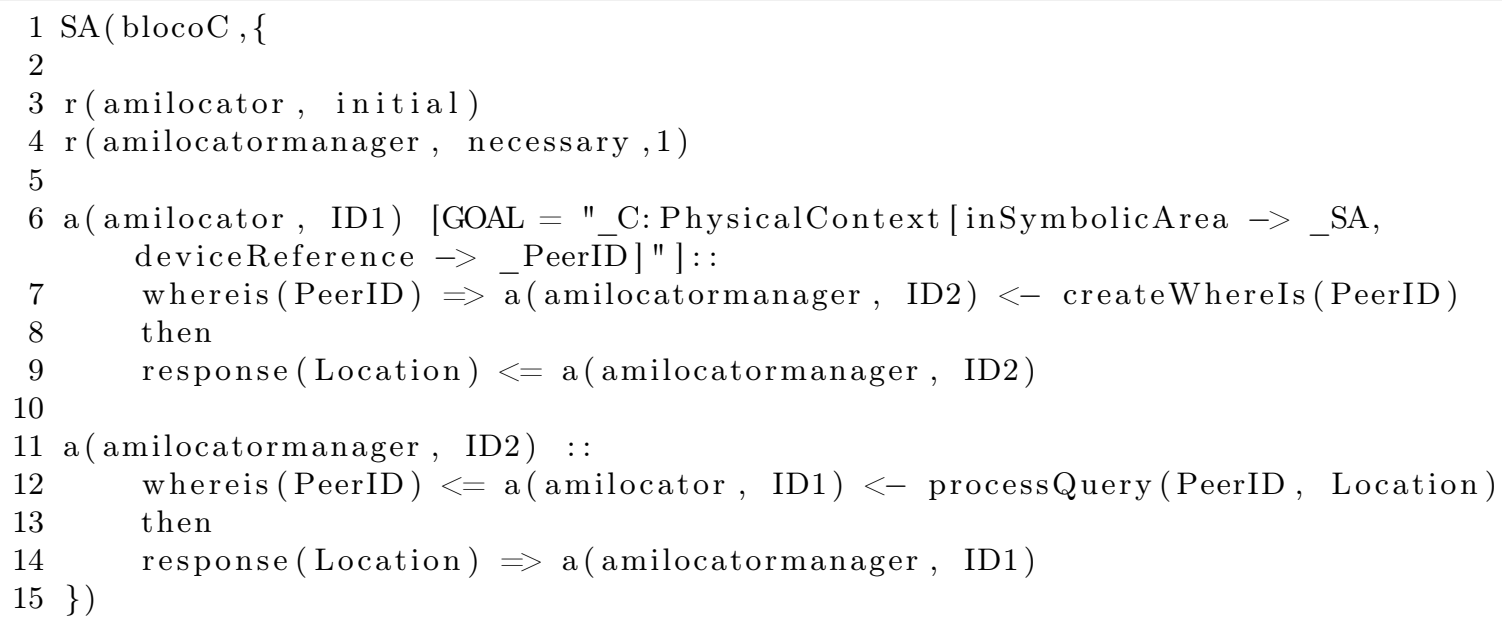

Código 5.9: Regra de interação para consulta de localização de agentes.

Outro importante aspecto deste exemplo é a restrição de interações do agente AmlLocator. No escopo de interação do agente crhisn_locator é declarado que somente pode interagir com o agente blocoC_locator. Isto é feito através da sentença allowed $=\{$ blocoC_locator $\}$ da linha 2 do Código 5.7. Desta forma, é definido que o agente crhisn_locator pode registrar sua localização somente quando se localiza no bloco C.

Neste mesmo cenário, é acrescentada outra funcionalidade através da regra de interação do Código 5.10, que permite o envio de uma mensagem de saudações do palestrante no auditório Gilioli a um novo participante que ingressa no auditório. Este palestrante é representado pelo agente crhisn_speaker que adota o papel speaker na regra de interação. O resultado desta interação se apresenta na Figura 5.6.

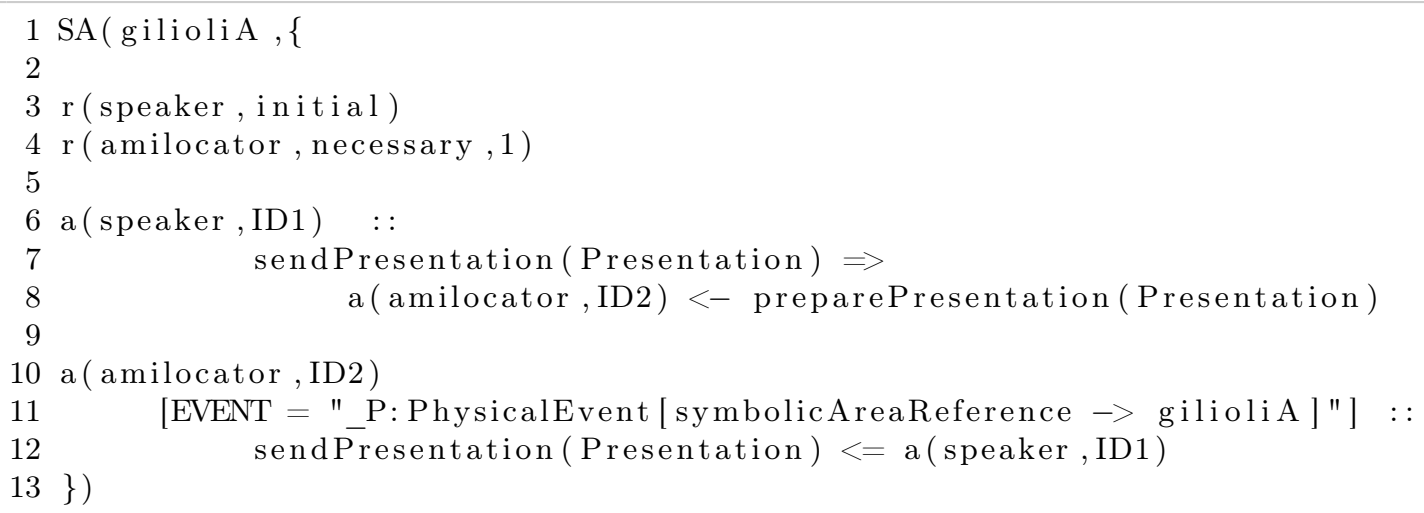

Código 5.10: Regra de interação do envio da apresentação do palestrante para um novo participante que acessa no auditório Gilioli.

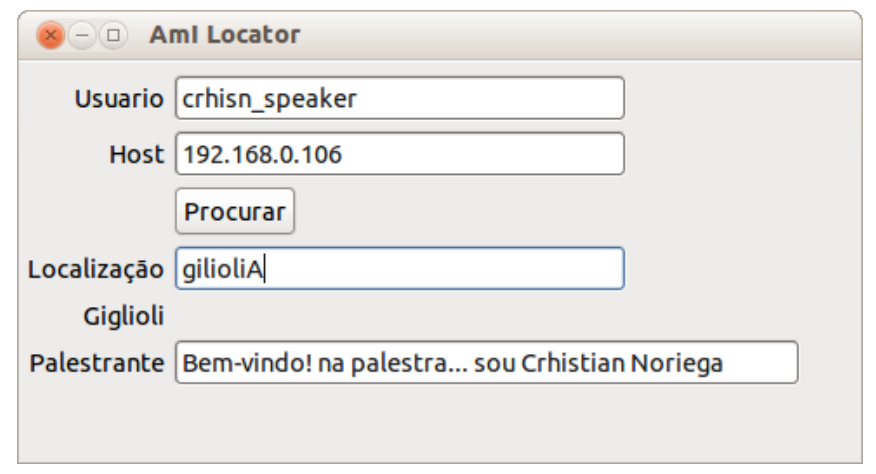

Figura 5.6: Tela de bem-vinda enviada pelo palestrante no auditório Gilioli. 
As interações para visualização de arquivos são executadas pela regra de interação apresentada no Código 5.11. O papel amifileshared representa o agente que fornece os arquivos e é executado em algum dispositivo móvel do usuário.

A regra de interação é iniciada quando o agente amifileshared acessa a área simbólica sala245A. Neste ponto é apresentada, na interface de usuário, a tela da Figura 5.7 que permite selecionar um arquivo no dispositivo do agente que é enviado enviado na mensagem sendFile. Continuando com a execução da regra de interação, o agente que adota o papel amifileviewer (agente display_fileviewer do Código 5.2) retorna um conjunto de dispositivos disponíveis e adequados para o processamento do arquivo (isto na mensagem devices).

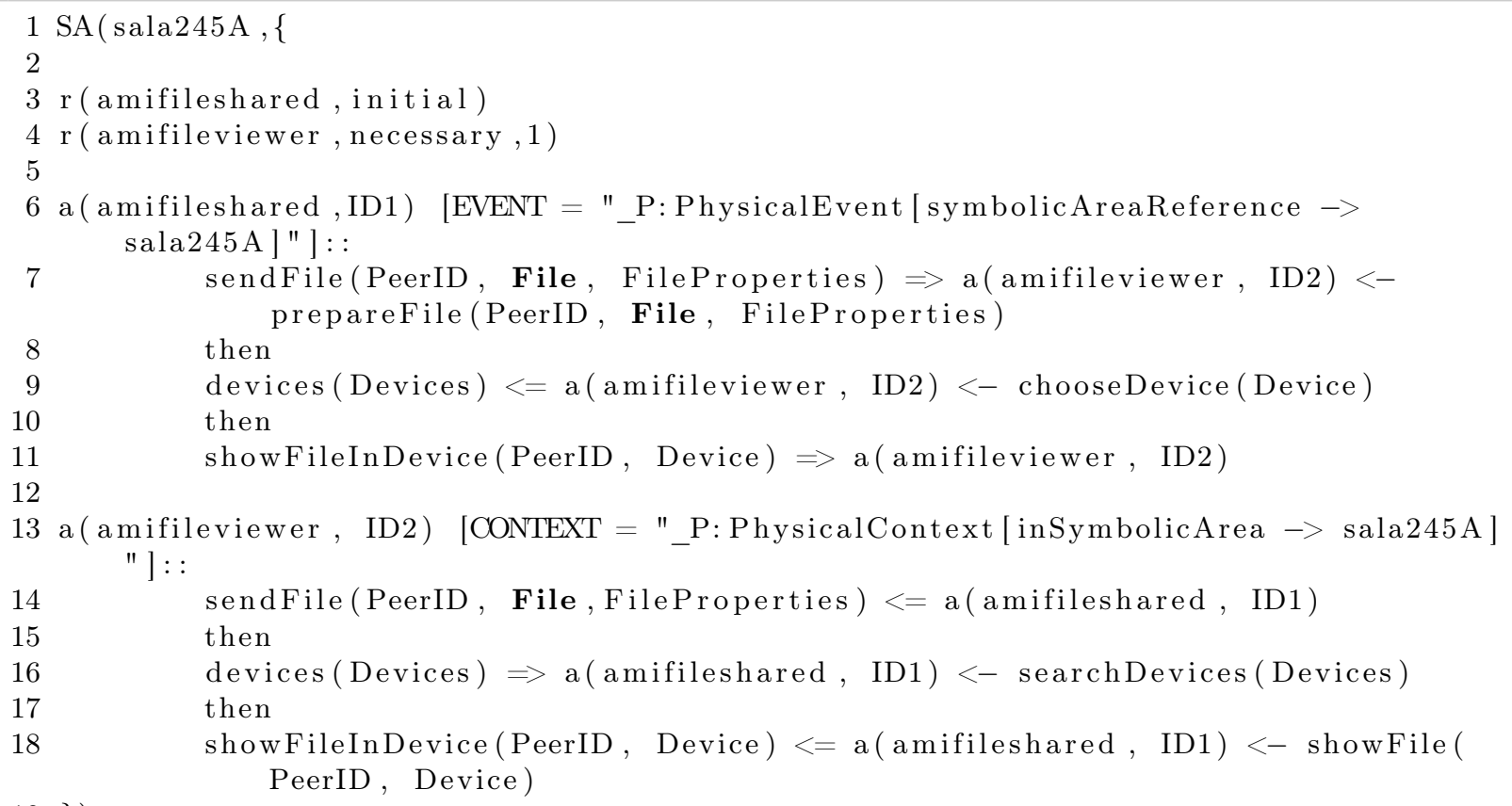

Código 5.11: Regra de interação para o compartilhamento e processamento de arquivos através do agente AmIFileShared.

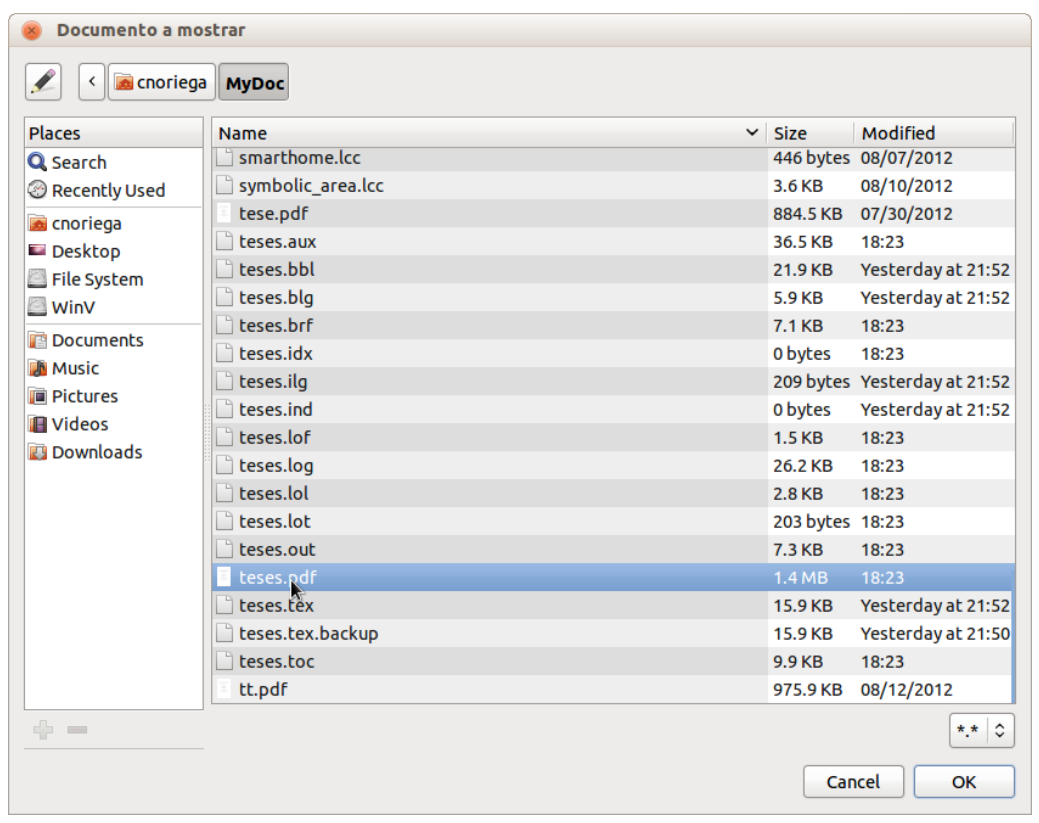

Figura 5.7: Interface do agente AmIFileShared para seleção e envio de arquivos. 
A Figura 5.8 apresenta a interface com a lista de dispositivos retornados pelo agente display_fileviewer para ser selecionado pelo usuário. Nesta implementação, são considerados mecanismos simples para processamento de arquivos, como evince e lpr do Linux.

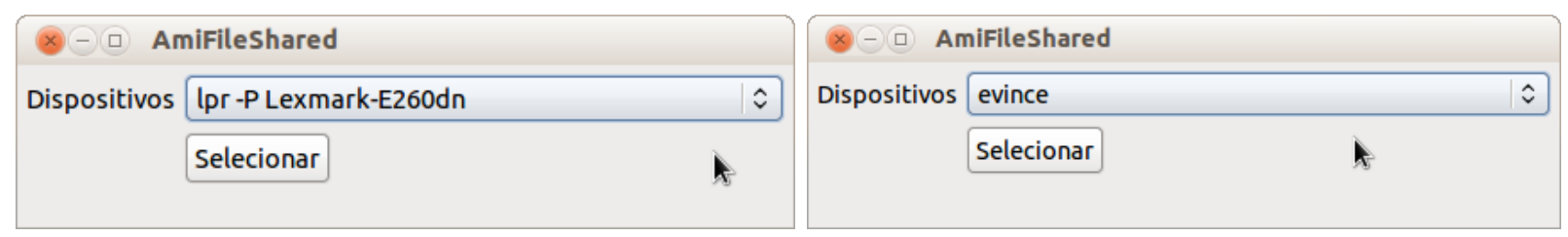

Figura 5.8: Seleção do dispositivo adequado para visualização do arquivo.

Neste mesmo cenário, é acrescentada a funcionalidade de imprimir arquivos segundo a impressora instalada na área simbólica em que o usuário se encontra. A seleção de arquivos é feito pelo agente que adota o papel amifileshared. O agente que adota o papel amiprinter segundo sua localização é definido na informação de contexto do papel da regra de interação (linha 11 do Código 5.12)

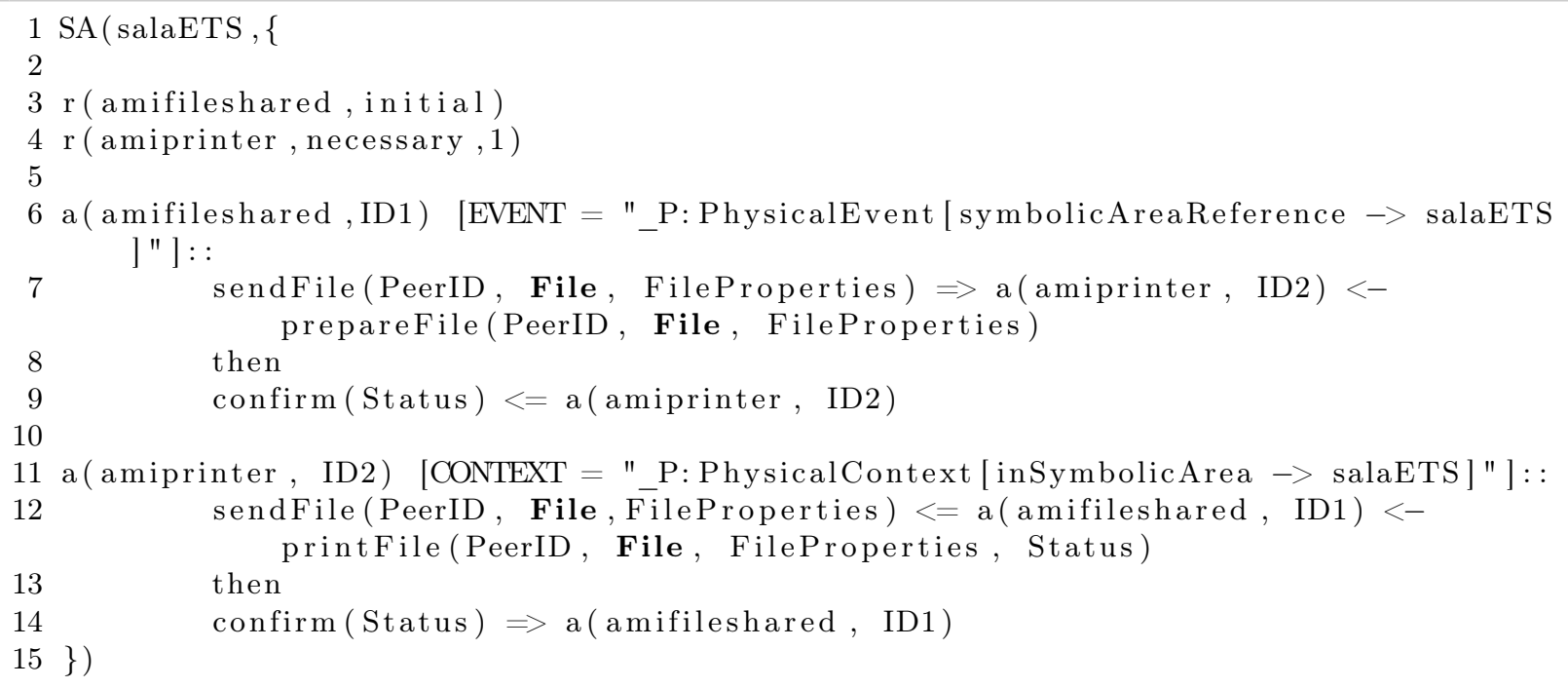

Código 5.12: Regra de interação para impressão de arquivos.

Neste exemplo, esta regra de interação é associada à área simbólica salaETS, que representa a sala das estações de trabalho do IME. Nesta área simbólica, este papel é adotado pelo agente printer_ets_amifileviewer do Código 5.2. Na área simbólica blocoB, este papel é adotado pelo agente printer_blocoB_amifileviewer. Neste ponto é chamada a interface padrão do sistema operacional para impressão (Figura 5.9), esta chamada é feita pelo agente no papel amiprinter correspondente. 


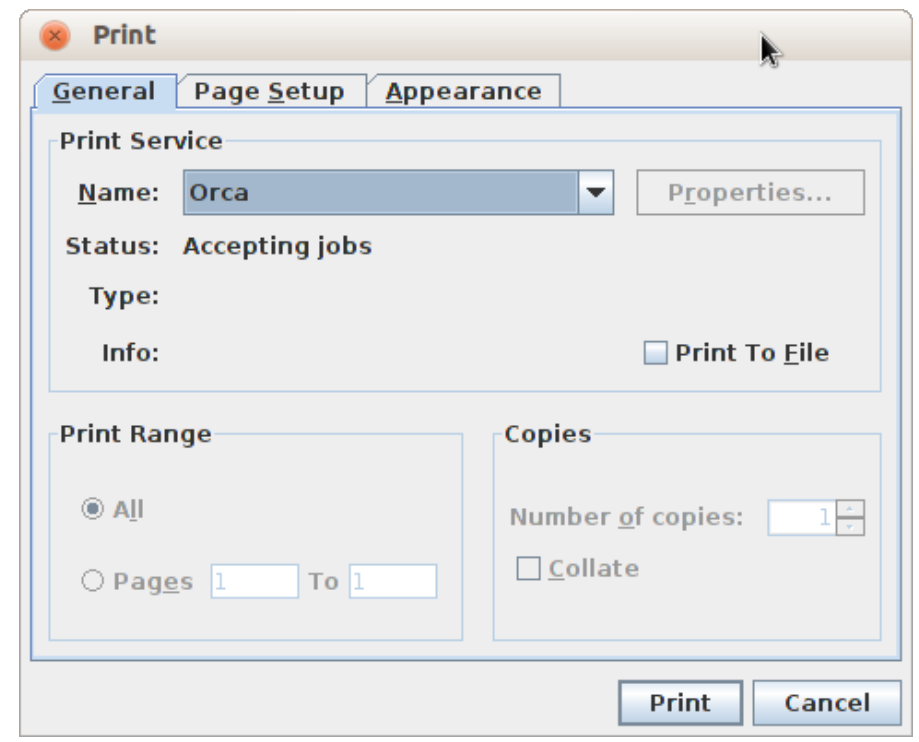

Figura 5.9: Impressão de arquivos na impressora definida na área simbólica das ETs (impressora Orca).

Finalmente, o Código 5.13 apresenta a regra de interação do agente AmIWelcome. Esta regra ativa a interação entre um agente que adota o papel amiwelcome (que está hospedado em um dispositivo móvel carregado por uma pessoa) e um agente que adota o papel amiwelcomeserver localizado na mesma área simbólica na qual a regra está associada. Desta maneira diferentes agentes fornecem funcionalidades diferentes segundo a área simbólica relacionada.

Note-se que diferentes agentes implementam de maneira diferente a restrição prepare da regra de interação (linha 10). Neste cenário, o agente na área simbólica libraryBlocoA, que representa o espaço físico da biblioteca, envia uma mensagem para um agente que ingressa nesta área com informações da biblioteca. O agente associado na área simbólica libraryBlocoA é executado em um dispositivo fixo conhecido como servidor do ambiente, como apresentado na Subseção 4.1.4.

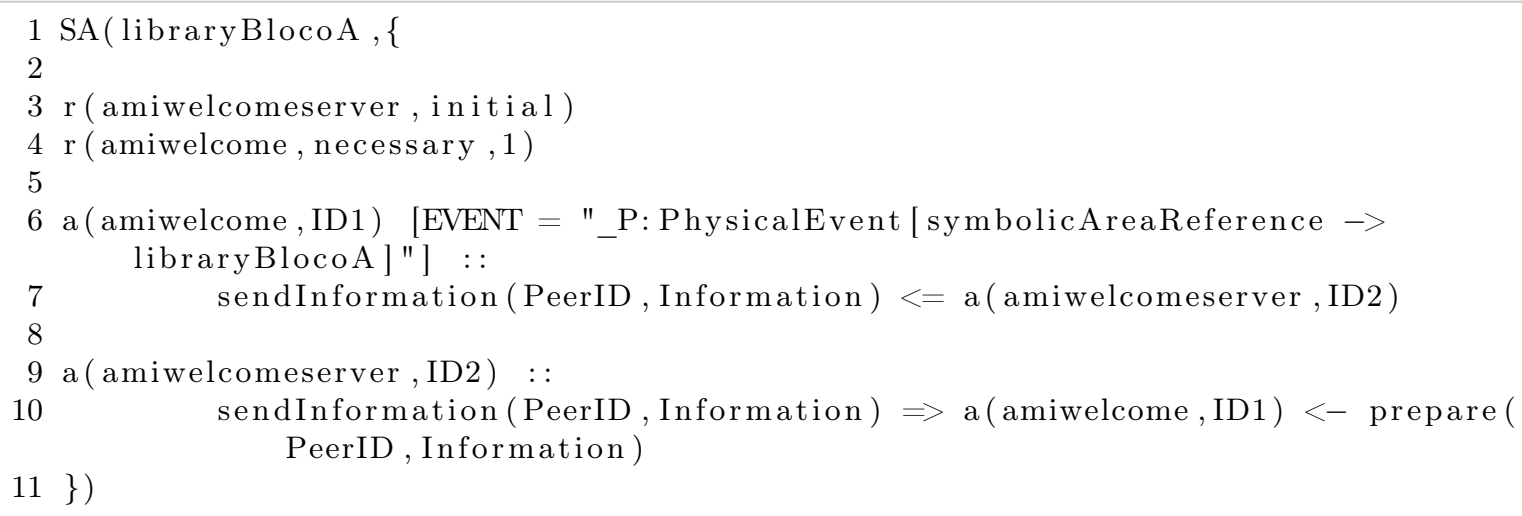

Código 5.13: Regra de interação do agente AmIWelcome.

\subsubsection{Integração do modelo com Jason e o agente AmlIME}

Como foi mencionado o agente AmIIME possui o modelo de inteligência BDI definido na linguagem AgentSpeak e implementado no Jason. No Apêndice B.3 se apresenta a especificação completa deste agente e uma breve descrição destes tópicos. A seguir apresentamos a integração do modelo com Jason com o propósito de explicar melhor a implementação do agente AmIIME.

O Código 5.14 apresenta um trecho da definição do agente AmlIME. As linhas 3 a 10 define as crenças inicias do agente. Sendo que as crenças com predicado info_role definem os possíveis papeis que o agente pode adotar. Por exemplo, a linha 3 define que pode adotar o papel amicalendar através do agente de nome crhisn_calendar (que é o mesmo nome definido na especificação do ambiente inteligente). O terceiro atributo é uma lista de parâmetros necessários para adotar o papel, neste 
exemplo, é o nome do usuário. E o quarto atributo indica o nome do método Java encarregada de retornar os objetos que são o resultado da interação do agente.

Foi criada a ação interna jason.amicore.actions.executeAsRole no Jason, a implementação desta ação é apresentada e descrita no Código B.4. Esta ação interna registra no ambiente de execução o papel que o agente pode adotar e somente retorna quando o agente faz parte de uma interação com esse papel.

Na linha 19 se mostra esta ação interna que recebe os seguintes atributos: (1) AgentName é o nome do agente definido no ambiente inteligente, (2) Parameters são os parâmetros necessários para adotar o papel, (3) Method é o nome do método Java a ser executado para recuperar o resultado da interação, (4) Results é o resultado da interação, este resultado é adicionado como crença do agente na linha 26 (através da expressão +events(Results)) e (5) Belief que representa a crença que o agente alcança como resultado da interação, esta crença também é adicionada na linha 27 (através da expressão +Belief). Note-se que os dois últimos atributos são calculados internamente como resultado da interação do agente no papel definido. Também é necessário notar que estes atributos são disponibilizados na base de conhecimento do agente mantida pelo Jason.

Desta maneira a interação de agentes dentro do modelo podem fazer parte na declaração de planos do agente de maneira tradicional em AgentSpeak. As linhas 18 e 29 mostra um destes planos. É importante notar que o resultado de interações disponibilizadas no entorno do Jason permitem iniciar outros planos. Por exemplo, o plano da linha 18 pode adicionar a crença is_speaker que iniciaria o plano da linha 29. Que para ser executado é necessário que os termos das linhas 30 e 31 sejam unificadas, isto é feito através das crenças is_speaker("Crhistian Noriega") e file_presentation("/home/cnoriega/tese.pdf"), das linhas 9 e 19 respectivamente. Além que a crença da linha 5 ativa a interação do agente com o papel speaker.

Este comportamento é o mesmo cenário descrito na Seção 5.2 onde o agente AmIIME fornece suporte para uma palestra (adotando o papel speaker) de maneira autônoma dependendo se o usuário é o palestrante de algum evento registrado no IME.

Finalmente, o processo é iniciado através do plano na linha 17 que define a meta principal do agente, sendo que esta meta é checada recursivamente através da linha 43 . O termo main goal é adicionado como resultado da execução de algum plano do agente, e portanto, de alguma interação com outros agentes.

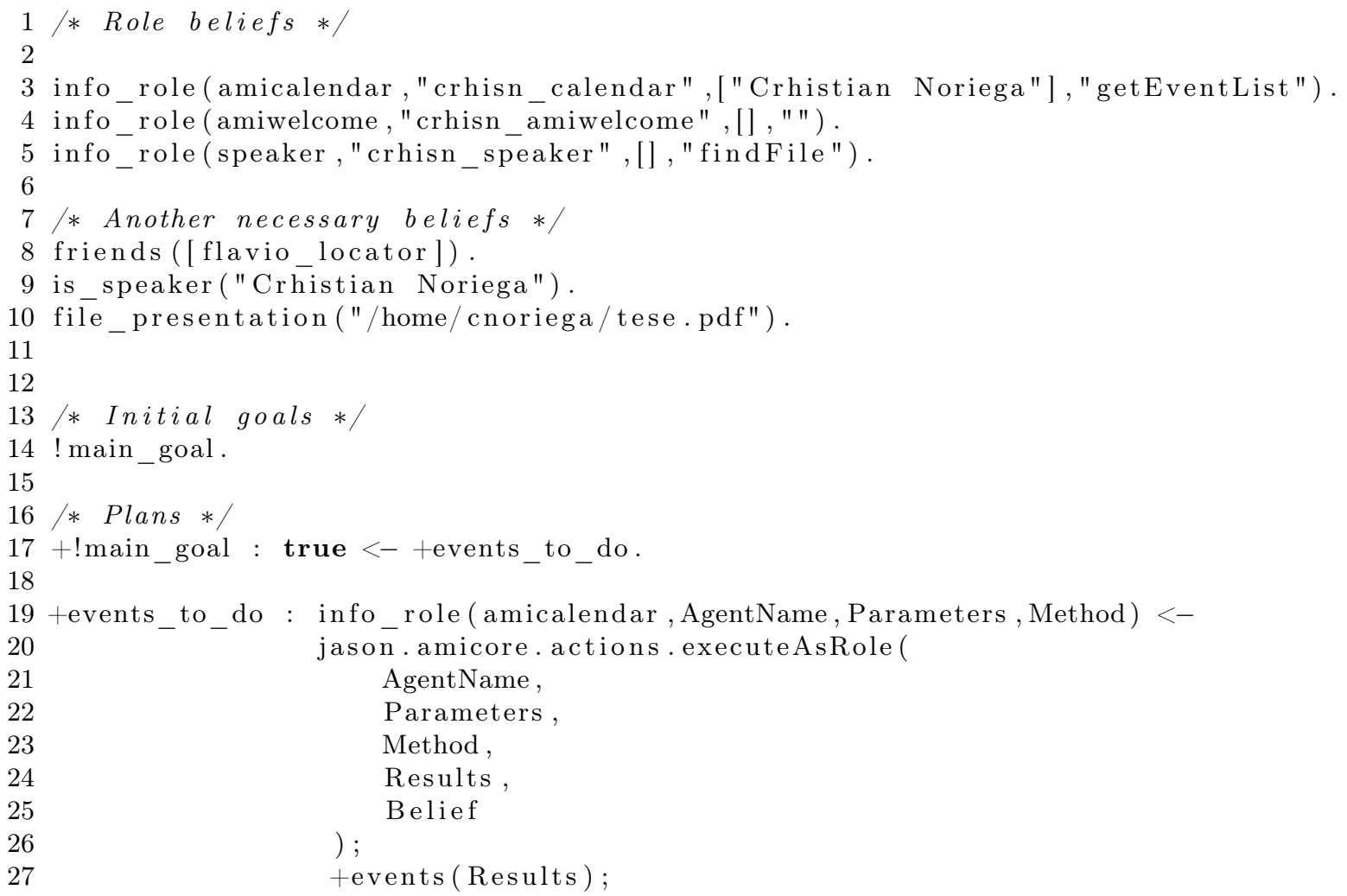


29

$30+$ is_speaker : info_role(speaker, AgentName, Parameters, Method) \&

$31 \quad$ is ${ }_{-}$speaker $\left(_{-}\right) \&$

32 file_presentation $($ File $)<-\ldots$

33 jason . amicore.actions . executeAsRole(

34

35

36

37

38

39

40

41

42

$43+$ main_goal : true $<-$-main_goal;-events_to_do;-have_events;

44

45

AgentName,

Parameters,

Method,

Results,

Belief

) ;

+wasShowed (Results);

+ Belief.

-is_speaker; - who_is_there;

! main_goal.

Código 5.14: Integração do modelo com AgentSpeak

A Figura 5.10 mostra a execução do Agente AmlIME dentro da console do Jason como resultado da execução da especificação em AgentSpeak detalhada no Código B.3.

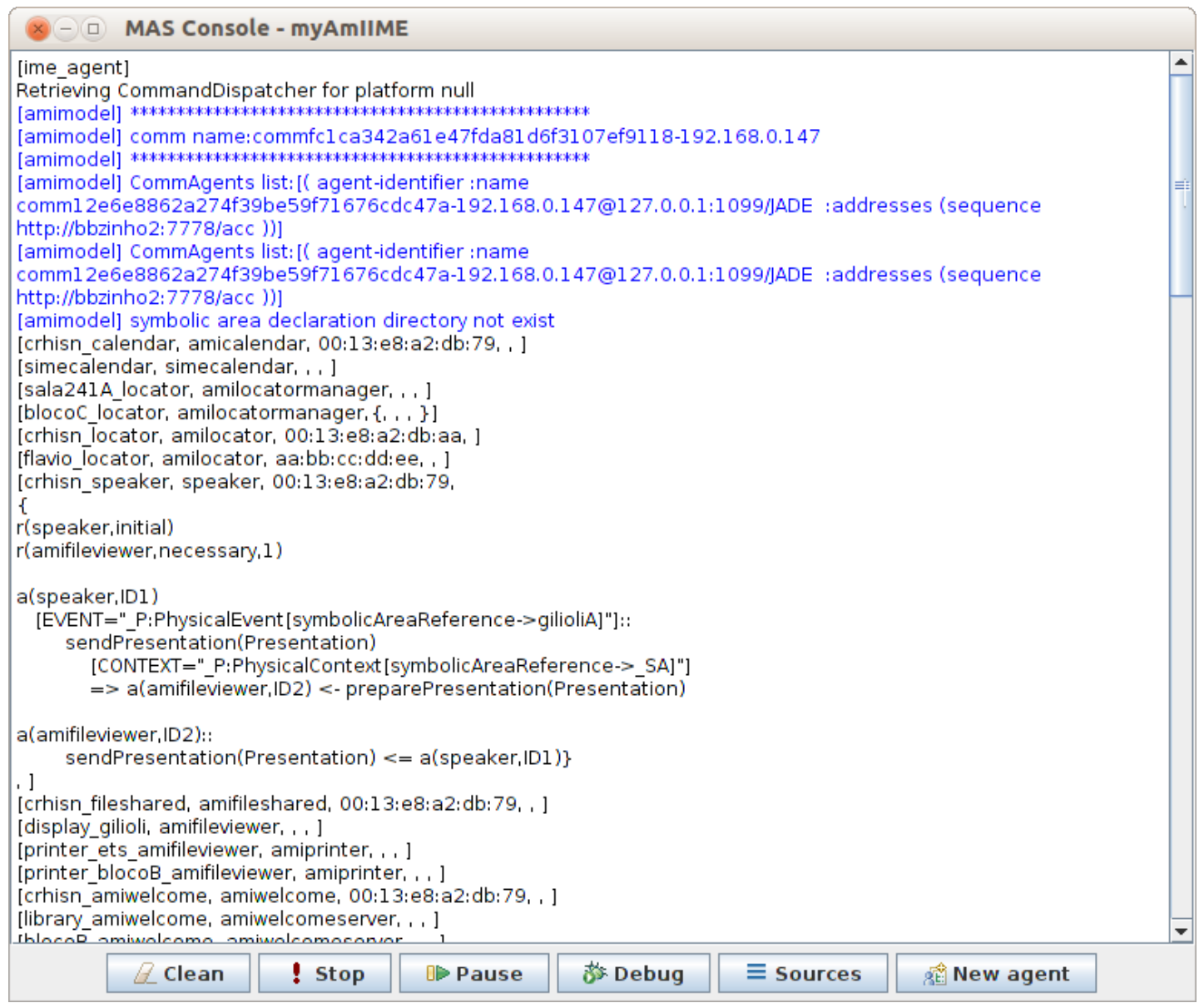

Figura 5.10: Execução do agente AmIIME dentro da console do Jason.

A integração do modelo com Jason fornece uma camada de inteligência composta por agentes autônomos que decidem quando interagir com outros agentes (adotando um papel determinado) segundo suas metas individuais. Isto apresenta um cenário poderoso onde o modelo proposto pode ser usado e exemplifica as idéias apresentadas na Subseção 3.2.2 sobre autonomia de agentes. Portanto, a autonomia de um agente não é limitada pelo modelo desde que o agente segue um plano 
somente quando possui as crenças necessárias. E logo de fazer parte de alguma interação o agente continua seu processamento com novas crenças acrescentadas na sua base de conhecimento obtidas como resultado de interações.

\subsection{Um modelo para ambientes inteligentes}

\subsubsection{Características fundamentais de projetos em ambientes inteligentes}

Exemplificamos, através do caso de estudo, como o modelo implementa as características listadas a seguir. Estas características foram traduzidas para o contexto do modelo proposto (organizações de agentes) a partir dos grupos de projetos apresentados anteriormente.

1. Componentes de software implementados como agentes.

2. Comunicação entre componentes de software como chamadas de métodos remotas.

3. Diferentes dispositivos abstraídos por interações de um agente.

4. Agentes adotam diferentes papéis em diferentes espaços físicos.

5. Modelagem e uso de informação de contexto em interações.

6. Interações sujeitas a eventos no mundo físico.

7. Interações guiadas por espaços físicos.

8. Agentes interagem com vários dispositivos ou serviços externos.

9. Interações relevantes entre agentes.

10. Agentes autônomos.

No caso de estudo, os pontos 1 e 2 são exemplificados através do agente AmICalendar e do serviço SIMECalendar. Estas entidades foram implementadas de maneira puramente programática, sem usar os mecanismos de descoberta e execução de interações do modelo. Isto foi feito através da API do ambiente de execução.

A interação entre esta dupla de entidades é contextualizada e demonstra a comunicação clienteservidor que é típica na implementação de sistemas computacionais. Além disto, como é típico também em aplicações sensíveis ao contexto, a informação de contexto do cliente (agente AmICalendar) é tratada pelo servidor (serviço SIMECalendar) para processar e retornar a informação mais adequada para o cliente. Estas entidades também exemplificam a capacidade de iniciar interações programaticamente e de receber e tratar eventos físicos e computacionais.

$\mathrm{O}$ agente AmIFileShared exemplifica os pontos 3 e 4 . Este agente permite interagir com impressoras e projetores (localizados em diferente salas do IME) da mesma maneira. Isto é, interações com este agente são traduzidas a interações com o dispositivo apropriado. É necessário observar que para este exemplo os dispositivos associados ao agente não são conceitualmente semelhantes, em outros cenários esta abstração pode ser mais natural.

Esta característica é ainda mais importante e necessária no caso de ambientes inteligentes. Neste cenário, diferentes dispositivos fazem parte de diferentes interações, e é necessário abstrair a interação com estes dispositivos.

Os pontos 5 e 6 são exemplificados pelo agente AmlLocator. Embora todas as interações iniciadas por este agente sejam iniciadas pela localização do dispositivo associado, a localização pode ser substituída por qualquer outro tipo de informação de contexto relevante no cenário do ambiente inteligente. Por exemplo, no desenvolvimento de smarthomes é necessário modelar e cumprir uma série de critérios para conseguir iniciar algum tipo de processo. Neste cenário, a ontologia na definição de eventos permite modelar critérios complexos e, por sua vez, iniciar interações complexas, como mostra o código a seguir: 


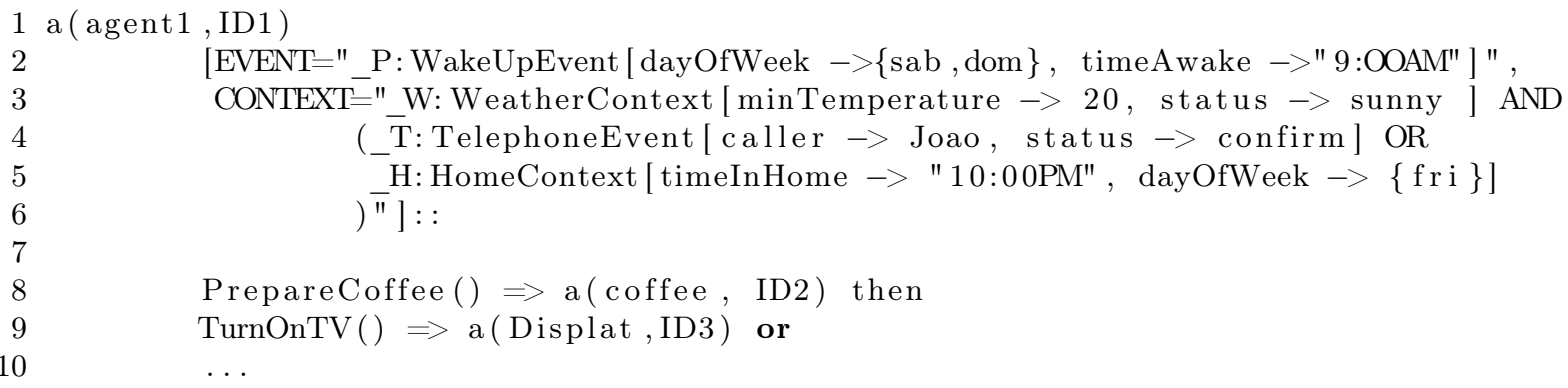

Código 5.15: Modelagem de informação de contexto em smart homes.

Neste código é definido ligar a cafeteira e a televisão (representados pelas mensagens Prepare Coffee e TurnOnTV, respectivamente) quando seja a hora de acordar no sábado ou domingo às nove horas da manhã (representado pela expressão _P:WakeUpEvent[dayOfWeek- $>$ \{sab,dom\}, timeAwake$>$ "9:OOAM"]). Além disto, o clima deve estar ensolarado e com uma temperatura mínima de 20 graus centigrados (_W:WeatherContext[minTemperature- $>20$, status- $>$ sunny]), ter recebido uma ligação de confirmação de João (_T:TelephoneContext[caller-> Joao, status->confirm]) ou ter chegado em casa na sexta-feira às 22 horas (_H:HomeContext[ timelnHome->"10:00PM", dayOfWeek->\{fri\}]).

Esta característica é ativada também pela capacidade de extender a ontologia da linguagem de especificação com conceitos do domínio de aplicação do ambiente.

O agente AmIWelcome apresenta como é possível ativar interações definidas em espaços físicos do ambiente inteligente. Este agente exemplifica o ponto 7 que é a característica principal do modelo proposto; também, o agente exemplifica o ponto 8. Estas duas características juntas permitem definir interações complexas que iniciadas fundamentalmente pela mudança na localização de dispositivos.

$\mathrm{O}$ agente AmIWelcome interage com vários outros agentes localizados em diferentes áreas simbólicas do IME segundo o dispositivo associado ao agente que se movimenta entre estas áreas simbólicas. Também interage com diversos serviços com o propósito de extrair informação útil nas interações. Estes dois pontos exemplificam os conceitos apresentado no Capítulo 3, onde é definido que áreas simbólicas definem interações entre agentes. É importante notar que, desde que ambientes inteligentes são definidos como espaços físicos interativos [Gag05, SG02]. Estes pontos por si próprios definem as características fundamentais de um ambiente inteligente.

O ponto 9 é exemplificado per se pela linguagem de especificação. A linguagem permite definir diferentes interações entre agentes em alto nível, os diferentes agentes implementados no caso de estudo fazem uso da linguagem em maior ou menos maneira, como é o caso do agente AmICalendar que usa definições da linguagem simplesmente para conseguir se comunicar com o serviço SIMECalendar. Já no caso do agente AmlLocator, que usa a ontologia da linguagem para definir eventos e informação de contexto necessárias nas interações.

No caso de estudo, o agente AmlIME é um agente autônomo (ponto 10) que pode se registrar interessado (por decisão própria) em papéis específicos para conseguir desempenhar as funcionalidades de outro agente. Isto fornece uma grande flexibilidade na modelagem de agentes que fazem parte de um ambiente inteligente.

\subsubsection{Grupo 1: Projetos focados no desenvolvimento de plataformas}

A implementação completa do ambiente de execução, como um middleware distribuído, cobriria as características destacadas deste grupo. No modelo proposto, a implementação destas características é feita implementando estes mesmos artefatos de software como agentes. As funcionalidades necessárias são suportados pelas camadas de serviços e infraestrutura como apresentados na Seção 4.3 .

No modelo proposto, são declaradas interações simples entre agentes que representam estas chamadas remotas entre agentes. Assim, regras de interações são definidas como simples chamadas remotas de objetos. Para isto, somente um componente de software (agente) pode adotar um papel 
em uma interação, isto é feito programaticamente registrando um único papel que o agente pode adotar.

\subsubsection{Grupo 2: Projetos baseados em interações de entidades inteligentes}

As características deste grupo são cobertas pelo desacoplamento de interações entre dispositivos e agentes do modelo proposto, isto é: (1) adoção de papéis por diferentes agentes, e (2) abstração de dispositivos como agentes. Papéis definem o comportamento de um agente, e não um agente em si, e é possível que diferentes agentes possam adotar um papel em alguma interação. Dado que a adotação de papéis é restrita por informação de contexto é possível: (1) reutilizar regras de interação em diferentes áreas simbólicas e (2) selecionar agentes como estado de contexto computacional, físico ou do domínio adequado para uma interação.

Considerando que agentes podem ser associados a diferentes dispositivos (como explicado na Seção 4.1.4), é possível interagir com diferentes tipos de dispositivos de maneira padrão, isto é, interações com dispositivos podem ser efetuadas da mesma maneira.

Dado as mesmas regras de interação podem ser associadas diferentes áreas simbólicas é possível ter as mesmas interações com diferentes dispositivos segundo o espaço físico e estado de contexto dos agentes envolvidos. Por exemplo, dependendo se em uma área simbólica se encontra uma impressora ou um projetor é possível enviar um arquivo desde um dispositivo móvel o que é interpretado como imprimir o arquivo ou apresentar o arquivo. Isto é exemplificado pelo agente AmIFileShared.

A Figura 5.11 mostra o agente agente 1, abstrai a interação com os dispositivos dispositivo $1 \mathrm{e}$ dispositivo 2 Um mesmo agente consegue interagir com diferentes dispositivos através dos componentes Body. Estes componentes se encarregam de converter eventos e informação no baixo nível do dispositivo em mensagens para o agente. Nos experimentos, a implementação do agente AmIFileShared coloca um documento na fila de impressão de uma impressora através do comando lpr do Linux, isto exemplifica de maneira muito simples o acesso a dispositivos em baixo nível.

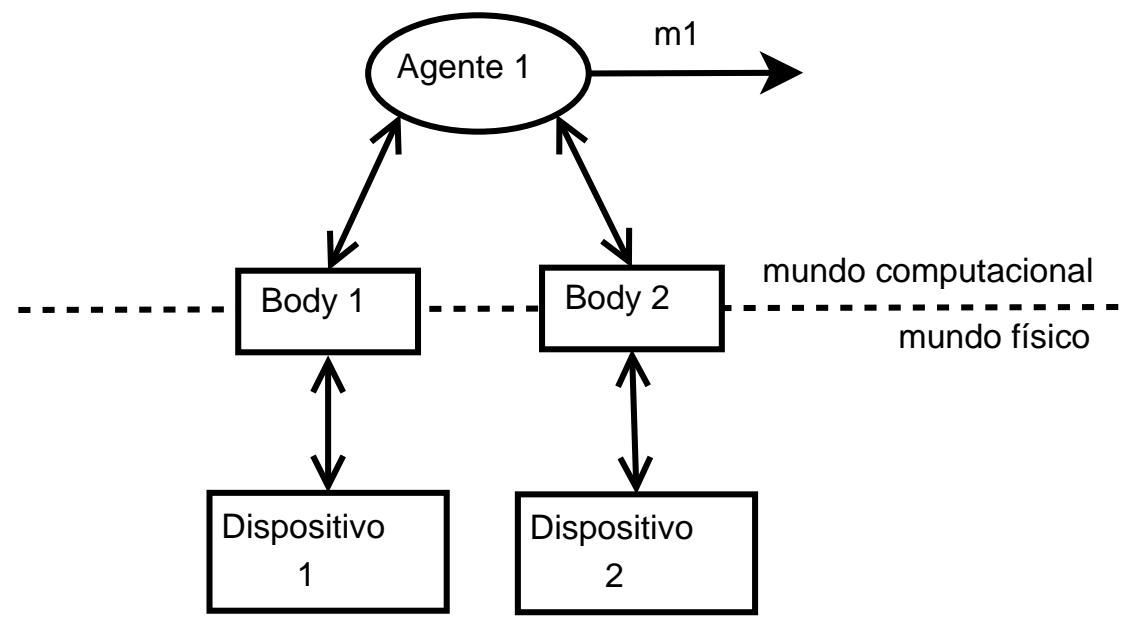

Figura 5.11: Associação dinâmica Body-Agente.

No Código 5.16 o papel impressora pode ser adotado por diferentes agentes segundo a informação de contexto definida na regra de interação (linhas 7 e 10). No exemplo, isto mostra como é possível enviar um documento para a impressora segundo o quarto se encontra (área simbólica). 


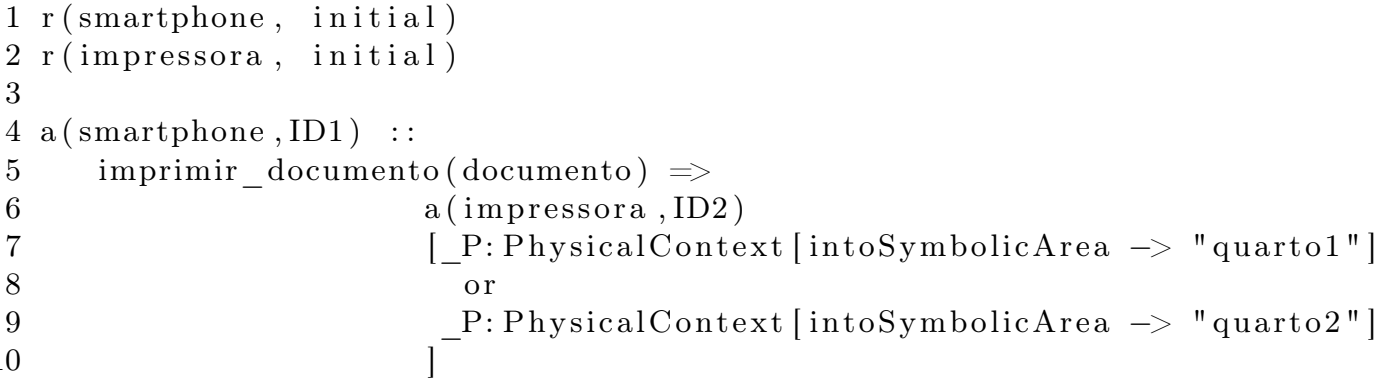

Código 5.16: Associação dinâmica Papel-Agente.

\subsubsection{Grupo 3: Projetos focados na percepção de humanos}

Neste ponto o modelo proposto permite a implementação livre destas características através da construção de agentes e dispositivos dotados com qualquer tecnologia e modelo de inteligência. Note-se que o único suporte fornecido pelo modelo para este grupo é a API do ambiente de execução que permite fazer parte de interações dentro do ambiente.

É importante notar que apesar esta liberdade seja permitida, todas as possíveis interações são controladas e executadas pelo modelo. Desta maneira, o modelo facilita abstrair interações entre diferentes dispositivos que implementam diferentes interfaces entre sistemas computacionais e humanos. Como exemplo simples consideramos interações com sistemas computacionais através de telas touch-screen, mecanismos de detecção de movimento ou telas convencionais através de mouse. Estes três tipos de interfaces produzem os mesmo tipo de interações.

O agente AmIIME é um agente autônomo que faz parte de interações por decisão própria.

\subsection{Padrões de uso do modelo}

Como resultado da especificação e ativação do caso de estudo apresentamos alguns padrões de uso do modelo proposto.

\subsubsection{Interações como chamadas de métodos remotos contextualizadas}

No Código 5.17 se mostra a estrutura deste padrão. O papel stub representa o componente de software que efetua a chamada e o papel remoto o componente de software que recebe a chamada. A chamada do método é representada pela mensagem chamada_remota que tem os parâmetros p1, p2 e p3. Da mesma maneira, a mensagem resposta representa o retorno da chamada remota.

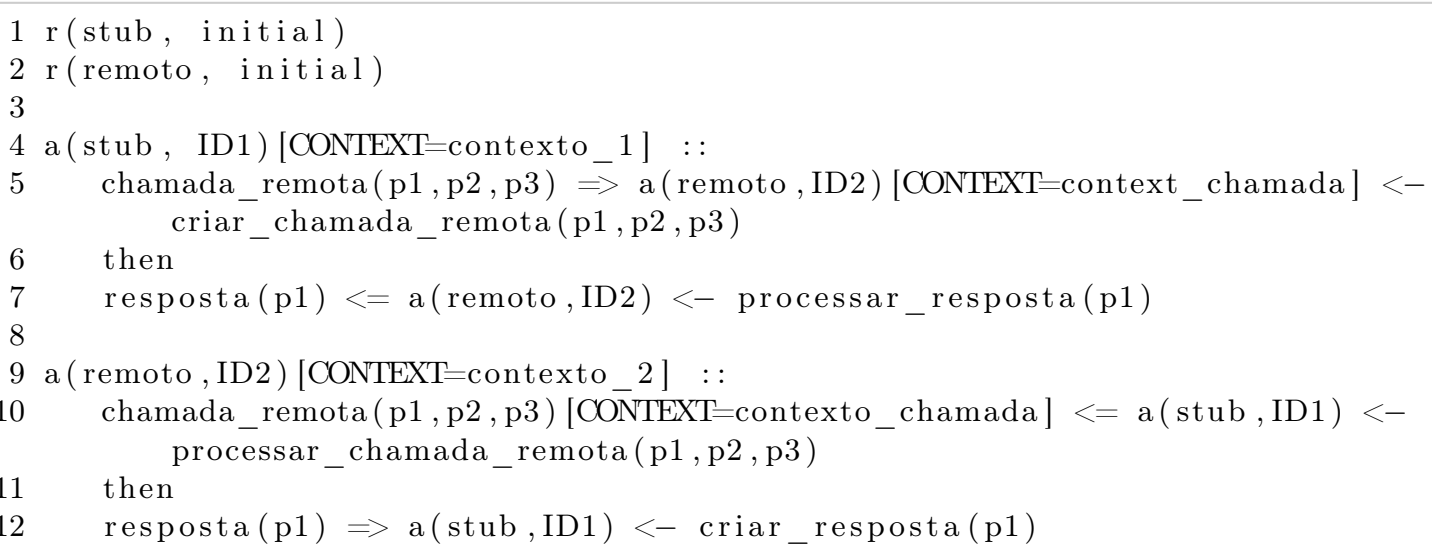

Código 5.17: Regra de interação que exemplifica uma chamada de método remota.

Neste cenário, são apresentados dois casos do uso de informação de contexto: (1) junto com a chamada remota (representado no termo contexto_chamada nas linhas 5 e 10), que é o caso do 
projeto PERSONA que usa esta informação para processar a chamada e processar a resposta da maneira adequada e (2) o contexto dos componentes envolvidos na chamada remota, como é o caso do projeto Gaia, isto é representado pela informação de contexto associada aos papéis (contexto_1 e contexto_2 nas linhas 4 e 9 respectivamente).

Note-se que no caso do modelo proposto e na abordagem de projetos baseados em implementação é necessário que ambos componentes de software conheçam os métodos e respostas destes métodos. Que é o mesmo caso de caso de conhecer os papeis definidos nas regras de interação.

O código 5.18 demonstra o uso de informação de contexto na descoberta de agentes adequados para receber uma mensagem, isto é, o estado de contexto do agente receptor. A regra é definida para enviar a mensagem $\mathrm{m} 1$ ou $\mathrm{m} 2$, segundo se o agente com o papel papel2 (linha 6 e 8) está ativo ou ocupado ([_P:UserContext[status -> "busy"] ou [_P:UserContext[status -> "active"], respectivamente) para finalmente enviar a mensagem $\mathrm{m} 3$.

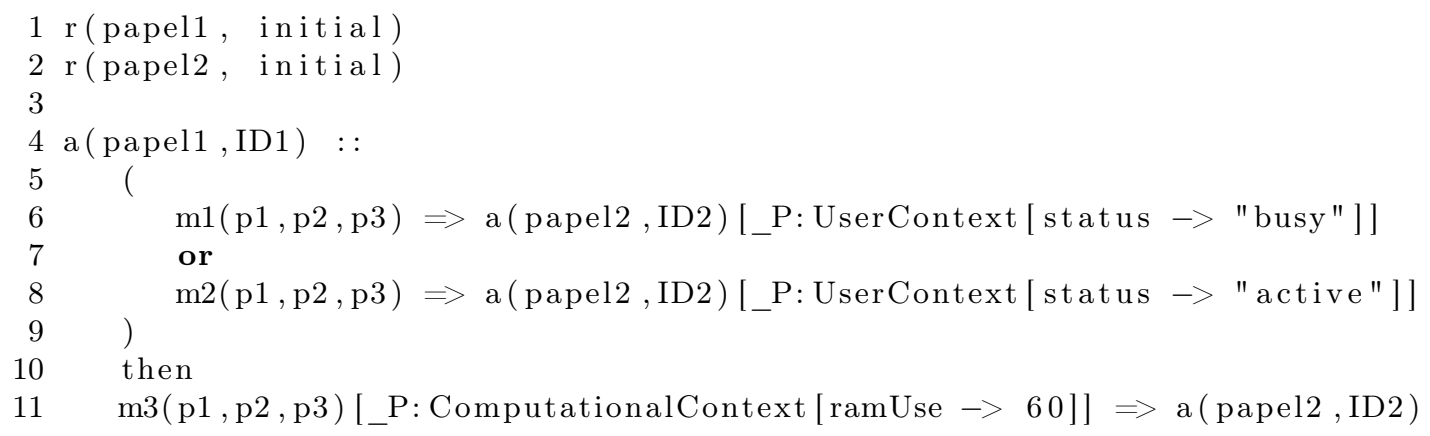

Código 5.18: Interações baseadas em informação de contexto.

Este padrão é baseado nas capacidades do ambiente de execução. Isto é, a deteç̧ão de eventos, manipulação de informação de contexto e início de interações são controlados programaticamente na implementação do agente.

Note-se que isto não contradiz o principio de organizações de agentes definido pelo modelo, pois a comunicação (entre o cliente e servidor) é definida como uma regra de interação onde o cliente e o servidor se registram para adotar os papeis adequados na comunicação.

A interações entre as entidades AmICalendar e SIMECalendar, apresentados no caso de estudo, apresentam um exemplo deste padrão.

\subsubsection{Interações iniciadas por localização}

Este padrão implementa a característica principal do modelo proposto. O Código 5.19 apresenta a estrutura de interação deste padrão.

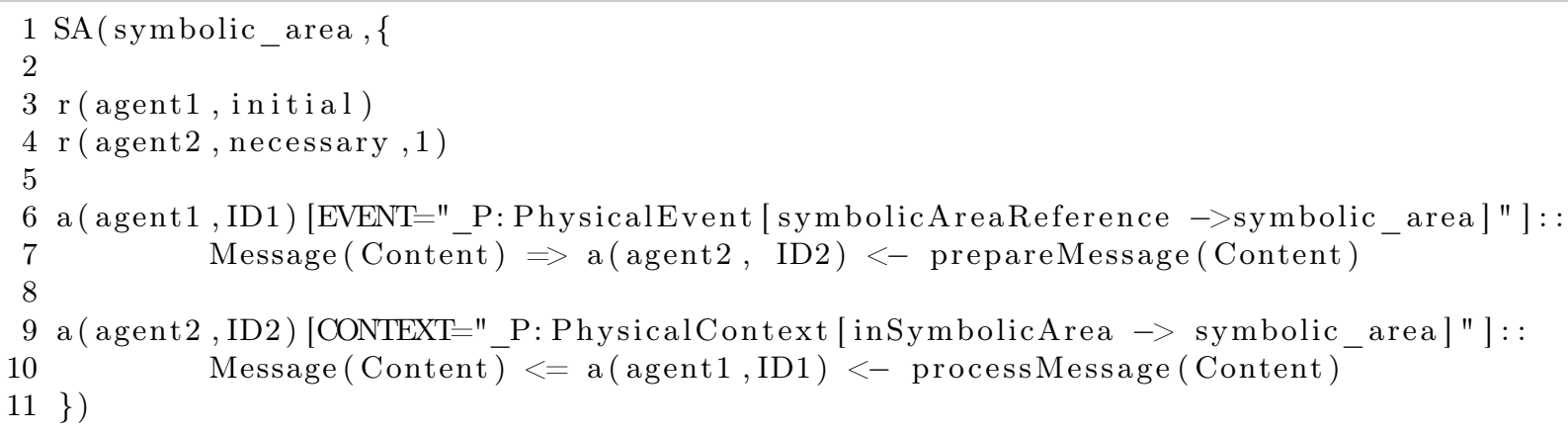

Código 5.19: Interações baseadas em localização de áreas simbólicas.

Este padrão associa a regra de interação desejada na área simbólica e é declarado o evento ao papel da regra de interação adequado que iniciara a interação.

No código acima, é definido o evento _P:PhysicalEvent[symbolicAreaReference -> symbolic_area] ao papel agent1 que define a execução da regra de interação toda vez que um agente se movi- 
menta dentro da área simbólica symbolic_area (linha 6), que no exemplo é o envio da mensagem Message(Content) para o agente que adota o papel agent2.

Neste padrão são definidos dois papéis, agent1 é o papel que representa o agente que se movimenta dentro da área simbólica symbolic_area, e o papel agent2 representa ao agente que já se encontra na área simbólica. Isto é definido pela informação de contexto _P:PhysicalContext [inSymbolicArea -> symbolic_area] associada ao papel da regra de interação (linha 9).

Note-se que a regra de interação definida pode iniciar outro tipo de interações entre outros agentes localizados na mesma área simbólica ou em outras.

No caso de estudo este padrão é exemplificado pelo agente AmILocator e AmIFileShared para compartilhar sua localização e arquivos em determinadas áreas simbólicas, respectivamente.

\subsubsection{Papeis em interações como abstração de agentes}

Este padrão se baseia no fato que diferentes agentes podem adotar um papel desde que satisfaça a informação de contexto necessária para adotar o papel. Isto permite ativar interações com diferentes agentes em diferentes contextos físicos e computacionais. Assim, a informação de contexto permite selecionar o agente mais adequado para adotar um papel determinado.

Dado que a ontologia pode ser extendida com o domínio de aplicação do ambiente inteligente sendo projetado, é possível usar esta ontologia para a seleção do agente que pode adotar um papel. Por exemplo, no código a seguir, além de exigir que o agente se encontre na área simbólica meetingroom, o conceito UserProfile requer que o agente esteja associado a um usuário cujo grupo de trabalho seja admin.

1 a (agent2, ID2) [CONTEXT="_P: PhysicalContext [inSymbolicArea $\rightarrow$ meetingroom ] and

2 _U: UserProfile [workGroup $\rightarrow$ admin] " ] : :

Código 5.20: Adoção de papel segundo a informação de contexto do agente.

No caso de uso apresentado, este padrão é usado pelo agente AmIFileShared para enviar arquivos para a impressora adequada em diferentes áreas simbólicas, conforme mostrado no código a seguir, a variável _SA (linha 1) pode ser substituída pela localização do agente que adotara o papel amiprinter, que é a localização de uma impressora. Isto traz como resultado para o usuário imprimir um documento na impressora mais próxima da sua localização.

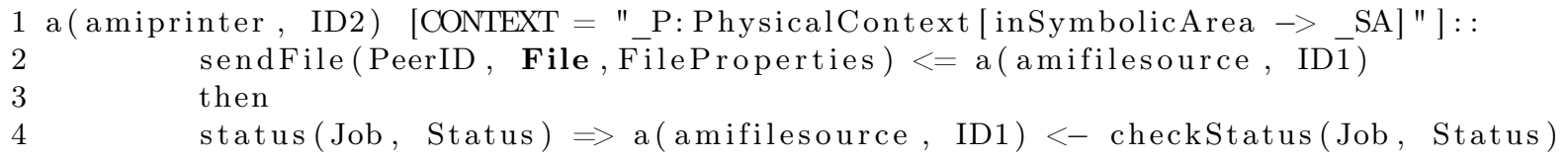

Código 5.21: Seleção de impressora por informação de contexto.

\subsubsection{Agentes como abstração de dispositivos}

No modelo proposto, agentes representam abstrações de dispositivos e qualquer interação com um dispositivo é feita através destes agentes. Esta característica permite desacoplar interações que acontecem no ambiente inteligente com a interação direta com o dispositivo e, portanto, com o driver que controla o dispositivo.

Este padrão permite que interações que sejam consideradas similares (mas dependentes do tipo de dispositivo) sejam tratadas e especificadas de maneira semelhante. Desta maneira, o agente é encarregado de interpretar estas interações de acordo com o dispositivo associado ao agente. Também, este padrão permite desconsiderar os dispositivos na interação, desde que é o agente que efetua os procedimentos necessários para interagir com os diferentes dispositivos.

O Código 5.22 apresenta o uso deste padrão. O papel resource_owner representa o agente que possui algum recurso que pode ser compartilhado (como um arquivo) representado na mensagem resource(Content, ResourceProperties). O papel resource_viewer representa um agente que recebe o recurso para ser processado de alguma maneira. Neste exemplo, é projetado a interação que 
permite escolher o dispositivo em que o recurso será processado, isto na mensagem devices(Devices); de uma maneira direta o agente com o papel resource viewer poderia já processar o recurso sem efetuar a consulta pelo dispositivo adequado segundo preferências do usuário ou disponibilidade do dispositivo, isto é decisão do agente.

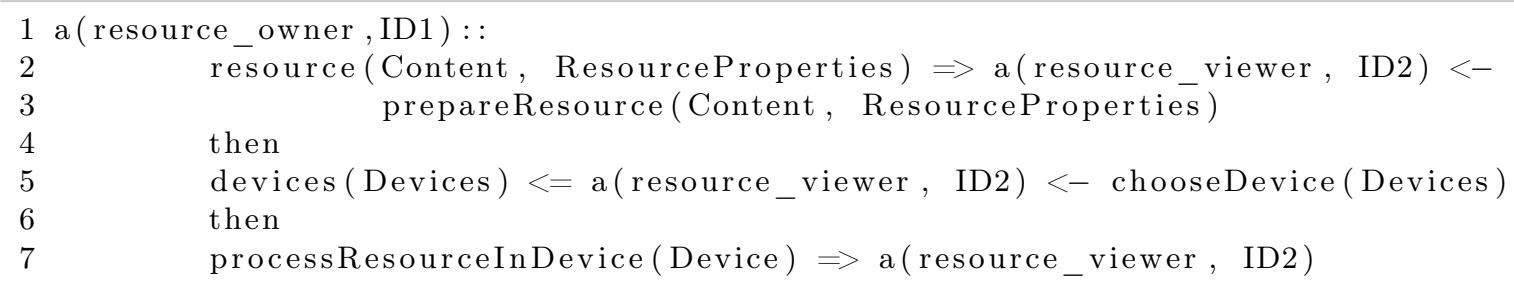

Código 5.22: Seleção de dispositivos na definição de interações.

Note-se que agentes abstraem dispositivos conceitualmente semelhantes no referente a interações dentro do ambiente inteligente.

\subsubsection{Pro-atividade no início de interações}

Este padrão define como a definição de eventos permite ativar interações entre um agente e vários agentes, isto é, a comunicação ponto-a-multiponto.

Neste ponto, é necessário rever os conceitos de cenário de interação e agente receptor do evento apresentados na Seção 4.1.9. Também, foi apresentado que o agente receptor do evento é o encarregado de iniciar a interação. Estes conceitos permitem associar eventos do mundo físico ou computacional a regras de interação segundo a necessidade no inicio de interações.

Por exemplo, considere o cenário onde um novo agente acessa a uma área simbólica (papel peerGreeter) e deve enviar uma mensagem de saudações para vários agentes que já se encontram na área simbólica (papel peerResponder). Continuando com este exemplo, os códigos a seguir mostram a mesma regra de interação com diferença no evento que iniciam a interação. No Código 5.23 o evento _P:PhysicalEvent[symbolicAreaReference->_SA] é definido no papel da regra peerGreeter, o que significa que a regra será iniciada toda vez que um agente acesse na área simbólica_SA. Por sua vez, no Código 5.24 o evento_P:PhysicalEvent[newAgentIntoSymbolicArea-> SA] é definido no papel da regra peerResponder o que indica que toda vez que um novo agente acesse na área simbólica SA se iniciara está interação.

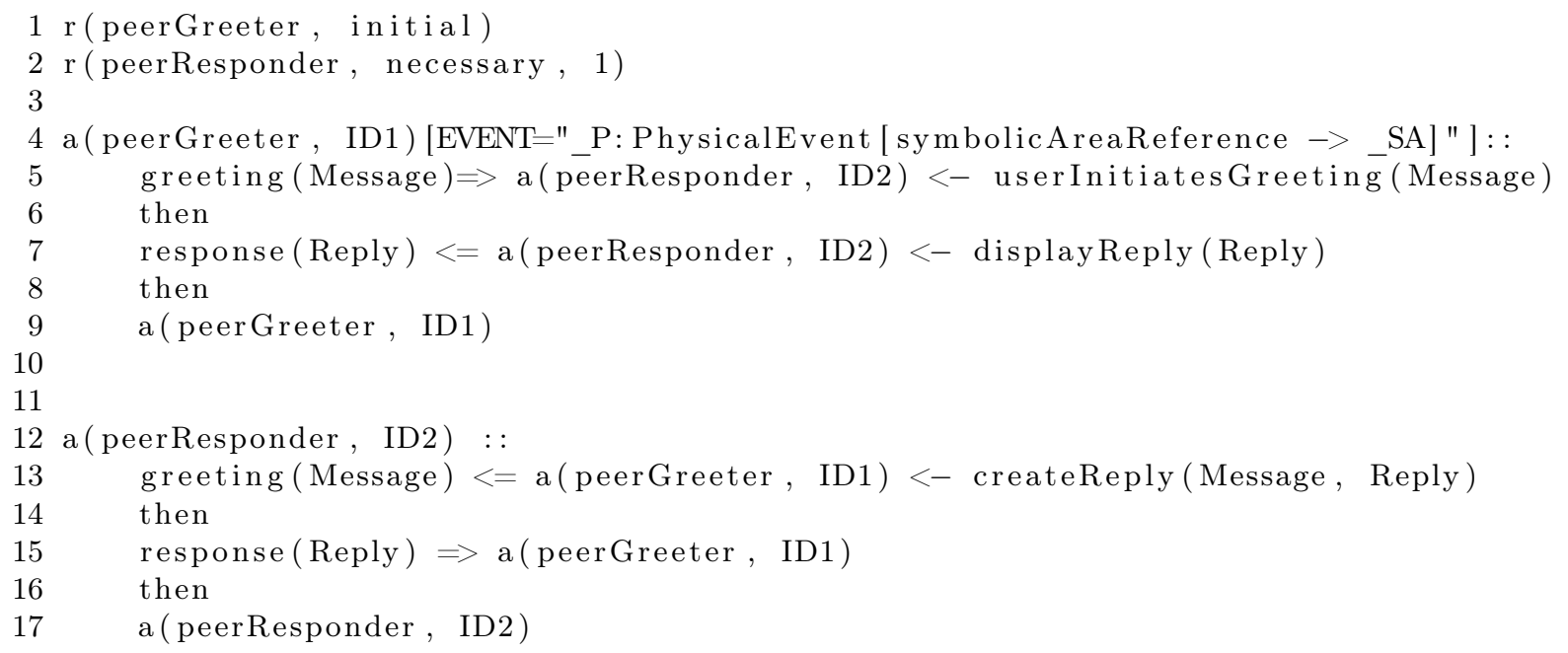

Código 5.23: Interação iniciada pelo agente no papel peerGreeter. 


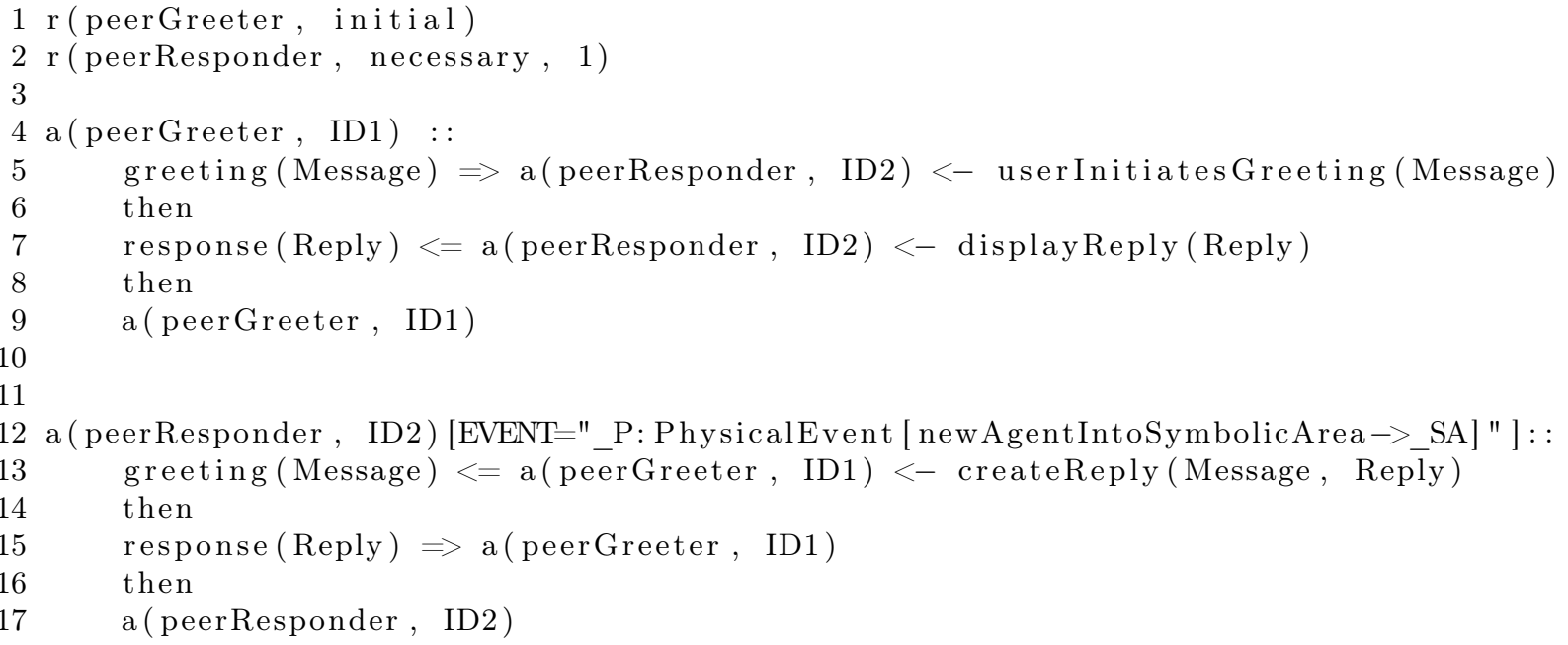

Código 5.24: Interação iniciada pelo agente no papel peerResponder.

Estas duas interações possuem cenários de interação diferentes. A primeira regra cria um único cenário de interação entre um agente que adota o papel peerGreeter, e um outro único agente que adota o papel peerResponder, porque o receptor do evento é o único agente que faz o papel do peerGreeter. Já a segunda regra de interação cria vários cenários de interação entre todos agentes que podem adotar o papel peerResponder e o novo agente na área simbólica que adota o papel peerGreeter.

Note-se que nas duas regras de interação é o agente no papel peerGreeter que inicia a interação.

\subsubsection{Padrões de interações baseados em LCC e AgentSpeak}

Desde que a linguagem de especificação do modelo é baseado no LCC, padrões de interação aplicáveis para o LCC podem ser aplicados também no modelo proposto. Neste site http://groups. inf.ed.ac.uk/OK/manual/manual.html é possível encontrar um resumo destas interações.

Também, com base na integração do modelo e Jason, é possível reutilizar padrões definidos para AgentSpeak no entorno do modelo proposto. Por exemplo, a checagem recursiva de metas apresentada na linha 65 do Código B.3 é um padrão de uso apresentado em [BHW07]. 


\section{Capítulo 6}

\section{Conclusões e Trabalhos Futuros}

Neste capítulo apresentamos as conclusões obtidas a partir do desenvolvimento e implementação do modelo para ambientes inteligentes apresentado no presente trabalho. Mostramos o potencial do modelo e suas principais características. Também expomos alguns trabalhos futuros possíveis.

\subsection{Capacidades do modelo para ambientes inteligentes}

Acreditamos que o potencial do modelo proposto surge a partir das seguintes características:

- Implementação de funcionalidades através de agentes: na visão de desenvolvimento de software [RA04], agentes cumprem o papel de componentes de software que são plugáveis na plataforma tecnológica do ambiente inteligente e que implementam e desempenham comportamentos específicos, os quais são definidos através dos papéis das regras de interação. Além disto, agentes são plugados segundo no seu estado de contexto, isto faz com que estes agentes sejam os mais adequados para desempenhar o comportamento requerido.

Diferentemente de componentes de software, agentes possuem as características de identidade, autonomia e inteligência que apresentam pessoas, dispositivos e aplicações típicas de um ambiente inteligente. Agentes são componentes adequados para a abstração de funcionalidades e dispositivos que podem existir dentro de um ambiente inteligente.

- Definição de interações em alto nível: no modelo apresentado as interações entre entidades de um ambiente inteligente podem ser livremente definidas através da linguagem de especificação. Interações são limitadas pelo espaço físico em que é definido o ambiente inteligente. Isto é possível a partir de nossa definição de ambiente inteligente como uma organização de agentes onde todas suas interações são definidas, conforme exposto no Capítulo 3.

A linguagem de especificação permite que interações com novas aplicações e dispositivos inteligentes no ambiente possam ser ativadas através de especificações na linguagem.

- Entidades em espaços físicos iniciam interações a partir de mudanças na informação de contexto: ambientes inteligentes são definidos sobre espaços físicos e as entidades envolvidas neste espaço físico. Isto faz necessário com que computação esteja associada a espaços físicos, através de dispositivos embutidos no ambiente ou através de modelos de programação que permitam a modelagem e ativação de um ambiente inteligente de maneira intuitiva.

O modelo define a execução de interações segundo mudanças de contexto de entidades que se encontram nesses espaços físicos, resultando em um modelo de computação embutido no espaço físico. 


\section{O modelo na visão de sistemas multiagentes}

É possível afirmar que o modelo proposto compartilha propriedades de sistemas multiagentes abertos [AG11]. A principal diferença é que o modelo define organizações de agentes em espaços físicos onde todas suas interações são pré-definidas.

Desta maneira, conceitos de inteligência e reputação de agentes presentes em sistemas multiagentes podem ser incorporados no modelo com o objetivo de incrementar suas capacidades. Por exemplo, agentes que tenham a tendência de falhar constantemente na execução de interações podem não ser mais selecionados para adotar determinados papéis, isto por ser implementado com base em mecanismos de reputação de agentes. Agentes com alto grau de inteligência podem ser capazes de processar e avaliar o conjunto de regras de interação presentes em áreas simbólicas para obter papéis e seqüências de papéis mais adequados para conseguir suas metas. Este último exemplo, não contradiz o princípio de organizações de agentes, dado que não é estabelecida nenhuma restrição no interesse de agentes por papéis, como é o caso do agente AmlIME apresentado na Seção 5.2 .

Também é possível aplicar conceitos de organizações de agentes dinâmicas que permitiriam ao modelo alterar especificações de ambientes inteligentes enquanto está em funcionamento. Isto se refere à alteração de regras de interação e papéis já definidos na organização do ambiente e não da adição ou remoção de novas regras e papéis.

\section{Implementação de ferramentas para modelagem e simulação}

A conseqüência mais evidente de usar uma linguagem de alto nível para a especificação e ativação de ambientes inteligentes é a criação de ferramentas que permitam a modelagem e simulação de ambientes inteligentes. Está é uma característica muito importante do modelo desde que é possível ter um modelo do ambiente inteligente sendo construído antes de ter uma implementação dos agentes e dispositivos que comporão o ambiente.

\section{Um padrão para a construção de ambientes inteligentes}

A separação dos aspectos tecnológicos da definição de interações entre entidades de um ambiente inteligente, permite que a especificação de ambientes e a implementação de ambientes de execução sejam feitos separadamente. Isto traz como principal conseqüência a evolução separada destes aspectos. Ambientes inteligentes podem ser definidos livremente segundo necessidades específicas sem depender do mecanismo de execução e, portanto, dos dispositivos e agentes que compõem o ambiente inteligente. Por outro lado, podem ser criados dispositivos com tecnologias de vanguarda e agentes com maiores capacidades de raciocínio sem a necessidade de conhecer as possíveis interações que ocorreram em um ou vários ambientes inteligentes.

\subsection{Trabalhos Futuros}

\subsubsection{Validação do modelo proposto}

Os experimentos efetuados permitiram exemplificar o uso do modelo através da implementação de aspectos comuns de outros projetos em ambientes inteligentes. Acreditamos que em um passo seguinte é necessário efetuar a validação do modelo. Para isto será necessário criar um cenário onde os atores apresentados na Subseção 4.1.10 sejam representados e produzam os artefatos definidos nas suas funções. Também, é necessário avaliar a qualidade dos ambientes inteligentes criados pelo modelo desde o ponto de vista destes atores.

Este processo permitira, principalmente, avaliar o desempenho e características do modelo quando agentes, dispositivos e ambientes inteligentes são desenvolvidos separadamente. Este processo envolve a validação dos seguintes pontos: 
- Espaços físicos influenciam organizações de agentes: este ponto envolve a validação das teorias sociais (apresentadas no Capítulo 3) sobre o comportamento de pessoas em espaços físicos onde existe um ambiente inteligente. No cenário de ambientes inteligentes, interações entre pessoas acontecem através de dispositivos e dependem das capacidades de processamento e comunicação destes dispositivos.

- Agentes, dispositivos e ambientes inteligentes desenvolvidos por diferentes atores conseguem interagir através do modelo: isto requer que os diferentes atores no projeto e ativação de um ambiente inteligente criem seus artefatos sem conhecimento da existência de outros artefatos.

- A linguagem de especificação e o ambiente de execução representam o modelo conceitual de maneira adequada: considerando que os três componentes do modelo são definidos separadamente, é necessário avaliar se a sintaxe e semântica da linguagem de especificação conseguem representar em sua totalidade o modelo conceitual.

- A qualidade dos ambientes inteligentes criados baseados no modelo: este ponto requer uma avaliação nas tarefas e percepção que cada ator tem no processo. Usuários do ambiente são de especial interesse e requer uma avaliação empírica de como o ambiente inteligente é percebido pelo usuário.

Cada um destes pontos traz dificuldades específicas que precisam de uma abordagem cuidadosa para sua validação. Esta tarefa requer maior tempo e esforço, e por isso é planejado ser efetuada em um trabalho futuro. Por exemplo, o último ponto requer a definição de uma serie de características na percepção dos usuários que demonstrem propriedades importantes de ambientes inteligentes. Neste ponto podem ser usadas as características apresentadas no Capítulo 2.

\subsubsection{Um modelo para ambientes inteligentes baseado em mirror worlds}

Foram propostos alguns modelos de interação homem-computador baseados no conceito de mundos virtuais e avatares [WG00, dad]. Um modelo que se tornou bastante popular durante a primeira década do século XXI foi o modelo proposto na plataforma Second Life [secb], que cria mundos virtuais como uma rede social onde pessoas interagem através de representações virtuais (avatares). Por outro lado, o crescimento do Google Earth [goo], que faz uma representação do mundo real (mirror worlds), surgiu a visão natural de unir estes dois modelos em um modelo único de interação.

Nesta visão, são criados mundos virtuais que são a representação do mundo real, onde representações de pessoas interagem entre elas e também com representações de entidades computacionais. Esta visão foi chamada de Second Earth [seca]. Já existem várias idéias sobre a união desses modelos, e alguns projetos concretos que buscam implementar essas idéias. Por exemplo, no Microsoft Maps [mic], é fornecida informação em tempo real sobre estradas, temperatura e clima de regiões representadas em um mapa real da área. Também, a DADEN Limited é uma instituição que vem trabalhando na implementação de ambientes virtuais dentro do Second Life que são representações de instalações da própria instituição [dad]. A DADEN mostra avanços na união entre os ambientes do Second Life e o mundo real. Por exemplo, as lâmpadas de uma sala são acesas a partir de um botão na representação da mesma sala dentro do Second Life. Neste cenário o mundo virtual representa um ambiente onde pode ser colocada informação adicional do mundo físico que não pode ser colocado nele, resultando que o mundo virtual oferece uma realidade aumentada para as pessoas (augmented reality)[Cen].

Com base no modelo apresentado, propomos uma nova visão de ambientes inteligentes que se caracteriza por dispositivos móveis servem como interface para interagir no mundo virtual com base em ações no mundo real, e vice-versa. O dispositivo é encarregado de capturar informação de contexto do mundo físico para manter a sua representação no mundo virtual. Assim, a representação da pessoa no mundo virtual ("alma") reflete a situação do dispositivo no mundo real ("corpo") que é controlado pela pessoa. É possível também que interações no mundo físico se refletem no 
mundo virtual, e que interações com entidades no mundo virtual sejam apresentadas no mundo físico (através de dispositivos especializados) criando um cenário de realidade aumentada. Com base nesses conceitos, chamamos nosso modelo de interação Corpo-e-Alma (Body-and-Soul).

O cenário descrito no modelo Corpo-e-Alma se alinha perfeitamente à visão de ambientes inteligentes $\left[\mathrm{DBS}^{+} 01, \mathrm{RVD}^{+} 05, \mathrm{Gag} 05\right]$. A visão de ambientes inteligentes define como principio a modelagem do mundo físico em sistemas computacionais. Assim, o modelo Corpo-e-Alma permite ter uma modelagem mais natural do mundo real, através do mundo virtual que o representa.

Nesta linha, projetos como FX Palo Alto Laboratory, Second Life, Microsoft Maps e Google Earth definem modelos de interação para mundos virtuais e o mundo real onde pessoas geograficamente distribuídas podem interagir através de sistemas computacionais. Também estes sistemas permitem apresentar informação do mundo real de maneira mais natural às pessoas através de representações virtuais.

Acreditamos que a separação do modelo nos seus três componentes permite a ativação de um ambiente inteligente não somente no mundo físico, se não também, no mundo virtual. Além disto, na visão de ambientes inteligentes apresentada anteriormente, é possível que o mundo físico e o mundo virtual sejam interligados através do modelo conceitual apresentado neste trabalho. Desta maneira, um middleware no mundo virtual seria o encarregado de executar regras de interação segundo a plataforma e propriedades do mundo virtual. 


\section{Apêndice A}

\section{API do ambiente de execução}

O código fonte da implementação do ambiente de execução está disponível em http://code. google.com/p/amimodel/source/browse, com o projeto em Eclipse de nome AmILCC_infrastructure.

\section{A.1 Classes e interfaces principais da API}

No Código A.1 apresenta a classe abstrata AmIModelCore que representa uma instância do ambiente de execução e implementa todas as interfaces dos serviços do ambiente de execução apresentados na Subseção 4.3.2. Além desses métodos, implementa os métodos necessários para a criação de componentes AgentBase a partir de declarações na linguagem de especificação, isto através do método createAgentBaseFromDeclaration. Também permite iniciar interações programaticamente a partir de: (1) um conjunto de regras de interação, através do método initlnteraction (linha 25), (2) iniciar interações a partir de eventos. O identificador do agente receptor do evento e o evento em si são passados como parâmetros no método initInteractionForEvent (linha 28), (3) iniciar interações segundo uma meta do agente através do método initInteractionForGoal que recebe como parâmetros o identificador do agente, a meta e a base de conhecimentos do agente (linha 31) e (4) iniciar interações segundo uma área simbólica através do método initInteractionForSymbolicArea que recebe com parâmetros o identificador do agente e a área simbólica a ser considerada (linha 34). Os métodos que iniciam interações retornam um identificador único que representa o cenário de interação produzido, (vide Subseção 4.1.9) isto com o propósito de efetuar um seguimento das interações do agente.

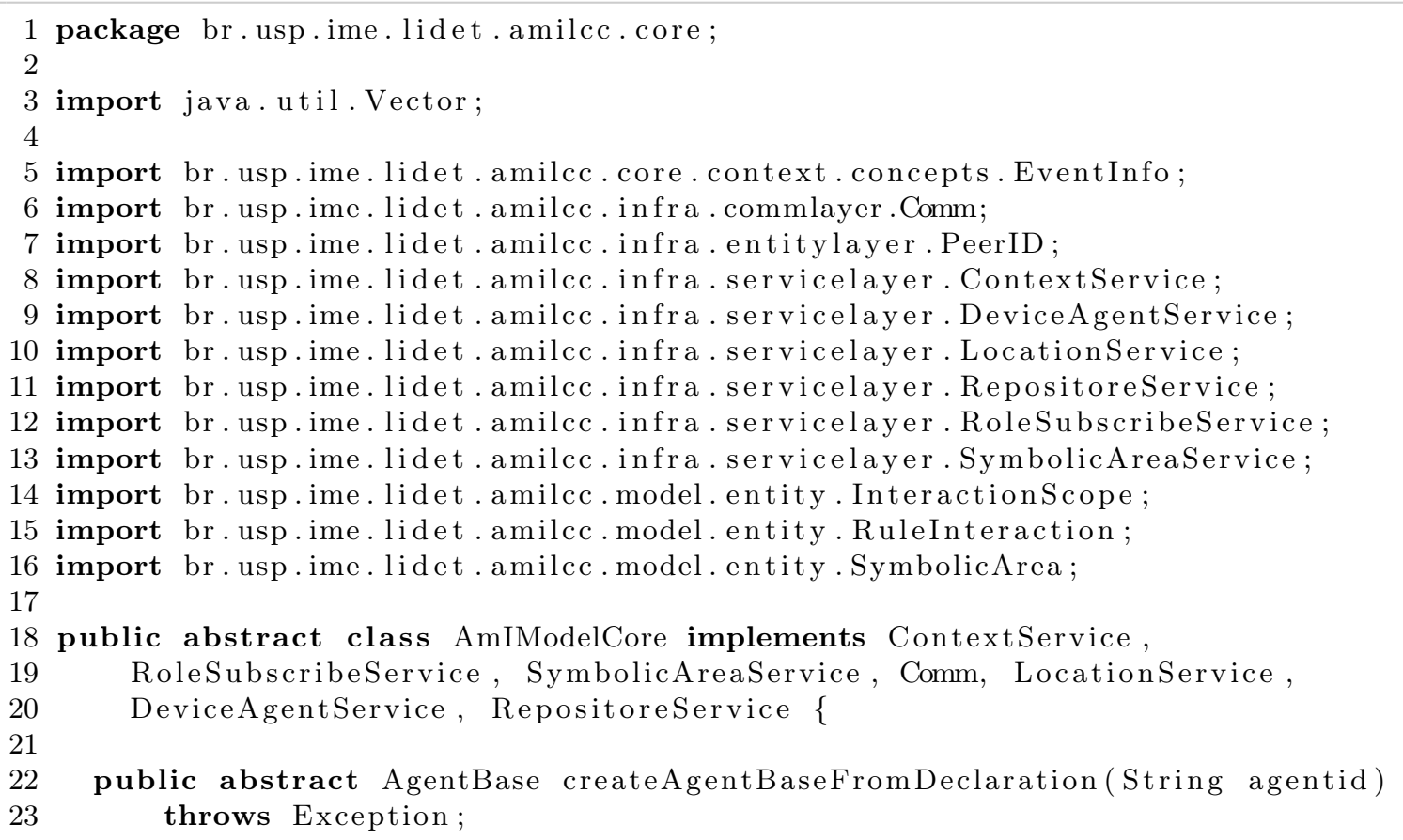


public abstract String initInteraction (PeerID targetpeer, Vector $<$ RuleInteraction $>$ rules) throws Exception;

public abstract String initInteractionForEvent (PeerID targetpeer, EventInfo eventinfo) throws Exception;

public abstract String initInteractionForGoal (PeerID targetpee, String goal, KnowledgeBase kb) throws Exception;

public abstract String initInteractionForSymbolicArea (PeerID targetpeer, SymbolicArea sa) throws Exception;

Código A.1: Interface Java do componente AmIModelCore.

A interface AgentBase representa o agente dentro da organização e é controlado por uma aplicação externa. O Código A.2 apresenta esta interface. Toda interação com este agente é feito através dos métodos definidos nesta interface. O método sendConstraintResponse da linha 11 permite enviar a unificação das condições definidas nas regras de interação (isto é, são associados objetos a argumentos definidos na condição) para continuar com a execução da interação. O método addAgentListener permite adicionar um objeto listener (vide Código A.3) para receber notificações das mensagens e condições na execução das interações. O método getld da linha 16 retorna o identificador único do agente. Os métodos addFactToKB e addContextToKB (linhas 18 e 20, respectivamente) permitem adicionar fatos e estados de contexto na base de conhecimento do agente. Na linha 22 o método addBodyBridge permite associar um componente Body com o agente. O método setAutoStartInteraction permite definir se o agente fara parte das interações de maneira automática quando acontecer eventos. O método registerMessageHandler permite registrar um objeto Java encarregado de processar as mensagens e condições das regras de interação, conforme definido na Subseção 5.3.5. Finalmente, o método initInteractionForGoal inicia interações com o agente com o propósito de satisfazer a meta passada como parâmetro.

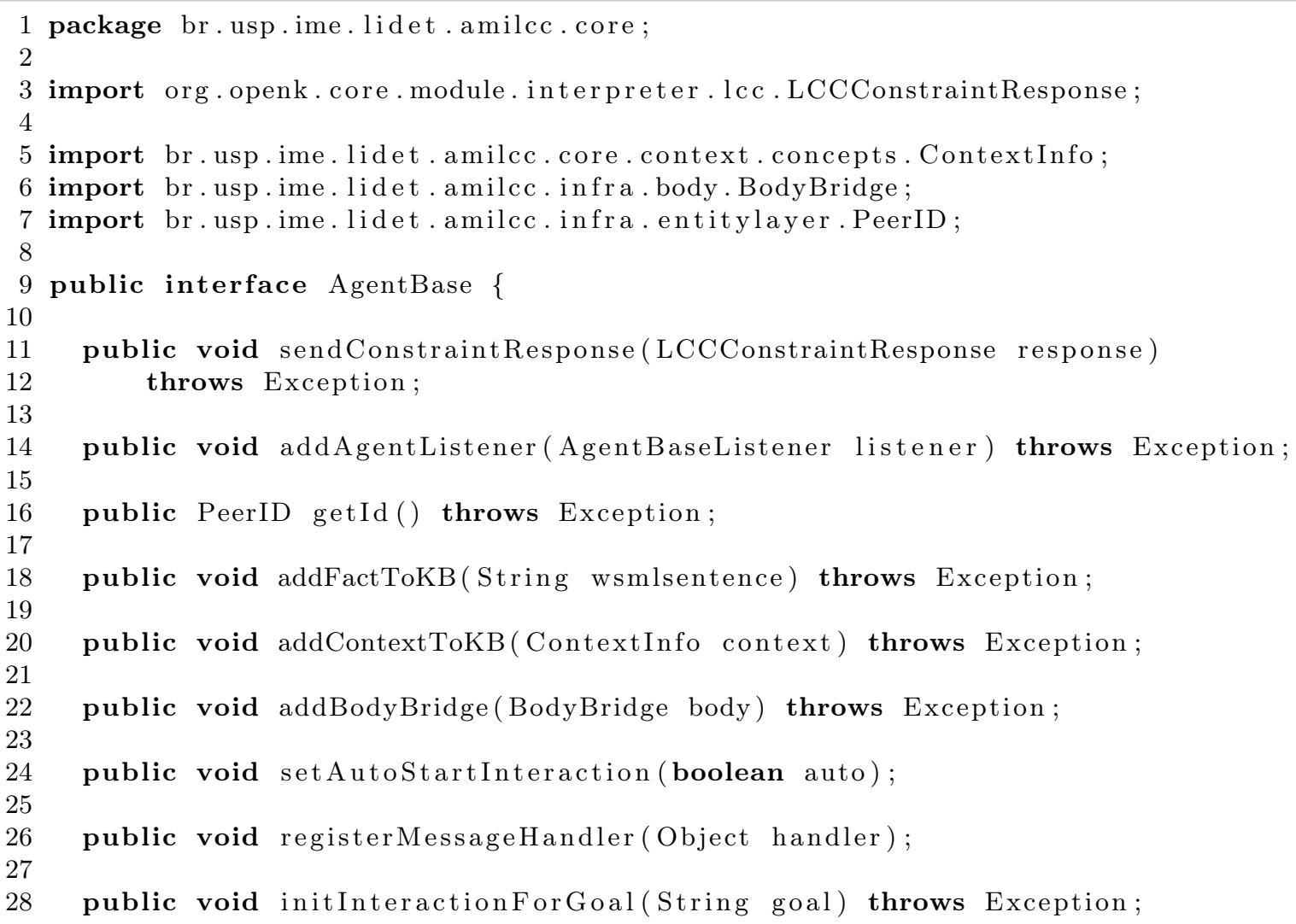


Código A.2: Interface Java do componente AgentBase.

O Código A.3 representa um listener que é utilizado para notificar ao agente sobre mensagens e condições produzidas na execução de regras de interação, isto através dos métodos notifyMessagelnfo e notifyConstaint, respectivamente. O método notifyEndlnteraction é chamado quando alguma interação da qual o agente fazia parte acaba. O parâmetro String sessionid é o identificador do cenário de interação correspondente, o parâmetro boolean result indica se a interação foi terminada em sua totalidade ou não e o parâmetro LCCSymbolTable arg1 devolve a tabela de símbolos correspondente aos argumentos definidos nas mensagens e condições. Finalmente, o método notifyEvent é chamado toda vez que é gerado um evento de interesse do agente.

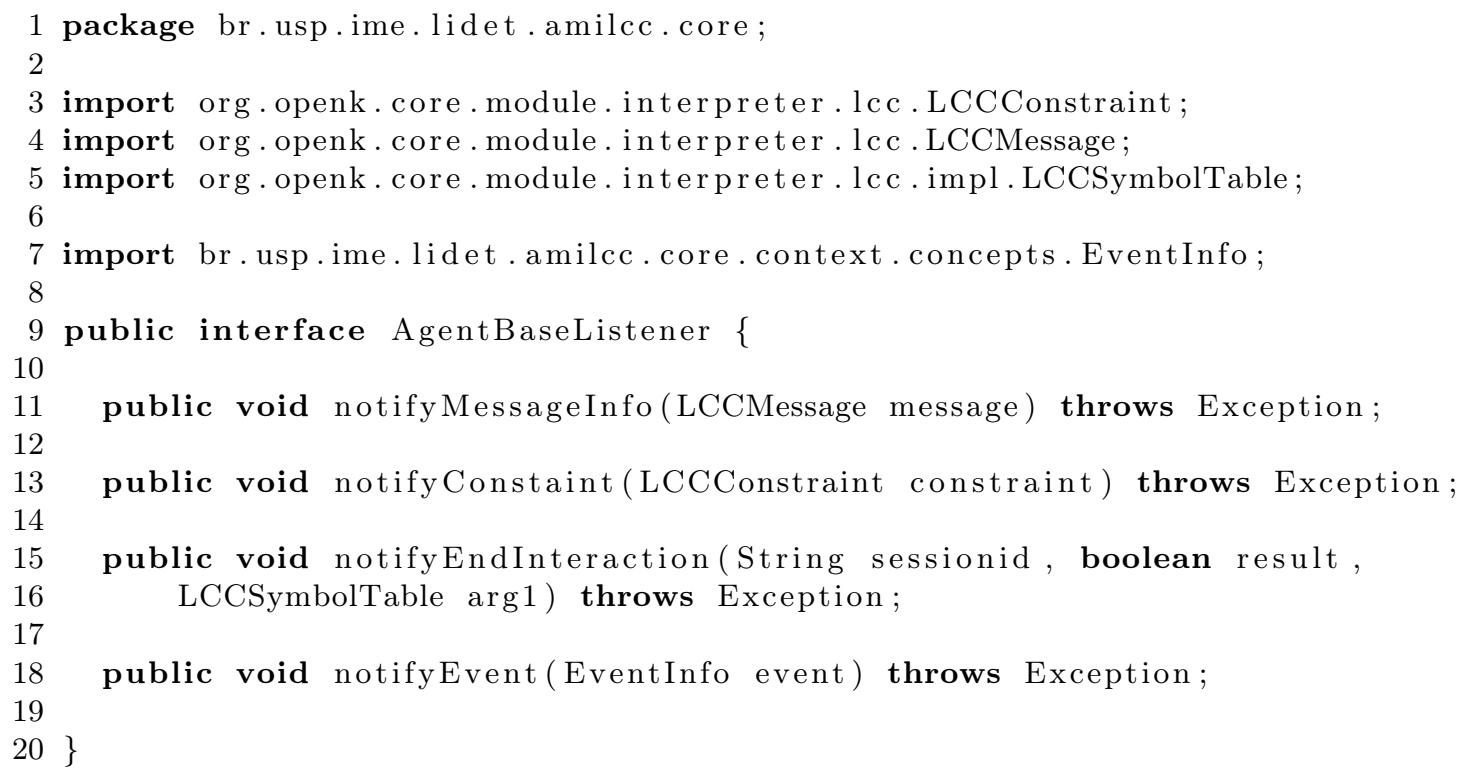

Código A.3: Interface do listener para notificação de mensagens e restrições

A classe abstrata BodyBridge, apresentada no Código A.4, representa o componente Body e deve ser extendida com uma implementação concreta segundo o tipo de dispositivo. Assim, esta classe serve de base para a integração com o driver do dispositivo. Os métodos que devem ser implementados são: (1) o método execute da linha 34, que permite efetuar uma chamada no dispositivo (tipicamente uma chamada a um componente de baixo nível como uma .dll ou .so), (2) o método isActive, que retorna o estado do dispositivo e (3) o método senseHardware, que obtém o estado do dispositivo, a implementação deste método deve notificar estas mudanças aos listeners registrados através dos métodos subscribeToContext e subscribeToEvents. As linhas 66 a 74 ativa esta checagem periodicamente.

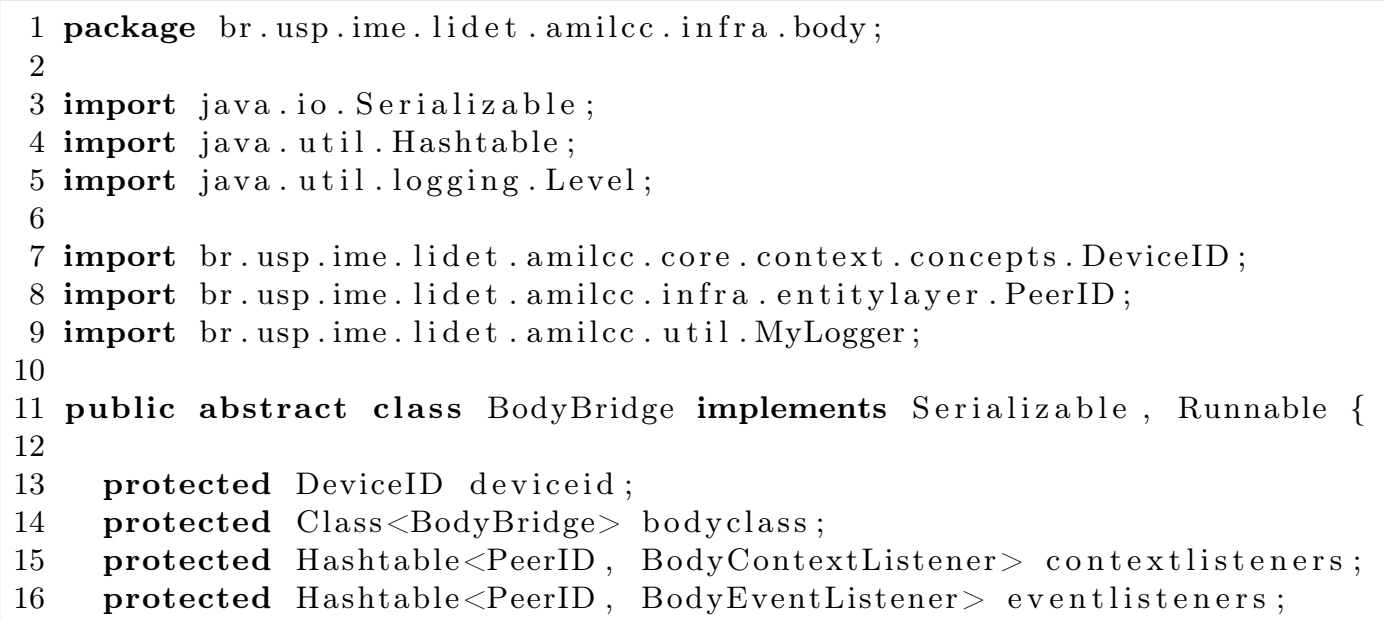


protected boolean localizable;

public BodyBridge(DeviceID deviceid, boolean localizable) throws Exception \{

this.deviceid = deviceid ;

this.localizable = localizable;

this. contextlisteners = new Hashtable $<$ PeerID, BodyContextListener $>()$;

this. eventlisteners = new Hashtable $<$ PeerID, BodyEventListener $>()$;

if (! is Active ()) \{

MyLogger . logger . severe("BodyBRidge not active or is Active method not implemented"); \} System . exit (10001);

Thread $\mathrm{t}=$ new Thread (this);

t. start ();

\}

public abstract Hashtable $<$ String, Object $>$ execute(String method,

Hashtable $<$ String, Object $>$ params) throws Exception;

public abstract boolean is Active() throws Exception;

public abstract void senseHardware() throws Exception;

public DeviceID getDeviceid() \{

return deviceid;

\}

public Class $<$ BodyBridge $>$ getBodyclass ( ) \{

return bodyclass;

public void setBodyclass (Class $<$ BodyBridge $>$ bodyclass $)\{$

this.bodyclass = bodyclass;

\}

public void subscribeToContext(PeerID peerid, BodyContextListener lis) \{ \}

this. contextlisteners.put (peerid, lis)

public void subscribeToEvents(PeerID peerid, BodyEventListener lis) \{ \}

this.eventlisteners.put (peerid, lis );

public boolean is Localizable () \{

\}

return localizable ;

@ Override

public void run() \{

MyLogger. logger.info("hardware sense initialized");

while (true) \{

try \{

this. senseHardware ( );

Thread.sleep (3000);

\} catch (Exception e) \{ \}

MyLogger. logger.log (Level.INFO, e.getLocalizedMessage (), e); \}

\}

Código A.4: Classe abstrata do componente Body. 


\section{A.2 Criação de uma instância do ambiente de execução e um Agent- Base}

O Código A.5 mostra a criação do agente AmICalendar. Este código cria uma instância do ambiente de execução na linha 25 , isto através do método createCore da classe AmIFactory que recebe como parâmetro uma lista de string de inicialização do ambiente de execução. O parâmetro -lisserver indica que a instância do ambiente de execução inicializa informação do serviço LocationService e o parâmetro -saserver indica que inicializa informação do serviço SymbolicAreaService.

Componentes AgentBase são criados a partir desta instância do ambiente de execução. Isto é feito na linha 26 através do método createAgentBaseFromDeclaration que recebe como método o identificador do agente definido da declaração do agente (vide Código 5.2). A variável AgentBase agent mantem a referência deste agente. E através desta variável que é feita a interação com o agente dentro do ambiente de execução.

$\mathrm{Na}$ linha 28 e associado programaticamente um componente Body no agente. A linha 29 ativa a execução de interações automática em mudanças de contexto. A linha 30 se registra no agente um handler de mensagens e condições definidas nas interações, que no caso é uma instância da mesma classe do agente.

As linhas 31 a 34 inicializam o estado de contexto do agente com informação de contexto físico. Isto define que o agente se encontra na área simbólica quarto2.

Nas linhas 41 a 76 se definem os métodos do handler que manipularam as mensagens e condições na execução das interações. Na prática, estes métodos são chamados pelo ambiente de execução quanto necessário segundo o estado na execução de regras de interação.

As linhas 85 a 97 mostram como iniciar uma interação programaticamente. Isto é feito através do método initlnteraction da instância do ambiente de execução que recebe como parâmetros o identificador do agente receptor do evento e uma lista de regras de interação a serem executadas. Note-se que este processo é feito automáticamente pelo ambiente de execução quando um agente recebe um evento (o primeiro parâmetro) e é feita a descoberta de regras de interação para este evento (o segundo parâmetro).

Finalmente, o método estático startup da linha 108 cria uma instância desta classe para execução. Aqui é criado e passado como parâmetro um componente Body que faz referência ao notebook identificado por 00:13:e8:a2:db:79 que o endereço MAC da interface de rede, resultado em um identificador único do dispositivo.

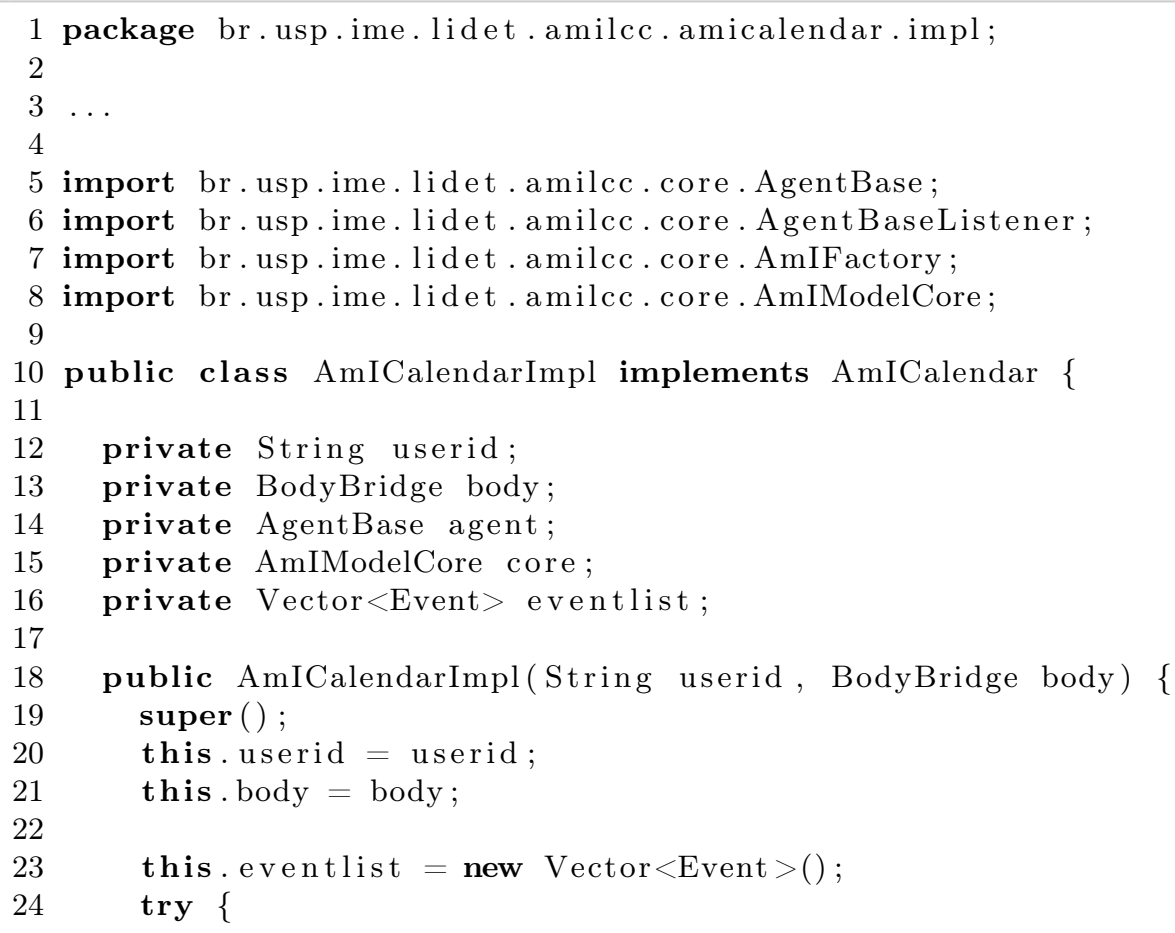


this. $\operatorname{core}=$ AmIFactory. $\operatorname{createCore}($ new String [] $\{$ "lisserver ", - saserver" $\})$

this.agent $=$ this. core.createAgentBaseFromDeclaration("crhisn_calendar");

this . agent. addBodyBridge (body);

this.agent. set AutoStartInteraction (true);

this.agent.registerMessageHandler (this);

PhysicalContext pc = new PhysicalContext (); pc.setInSymbolicArea (new Symbol ("quarto2")); this . agent . addContextToKB ( pc) ;

\}atch (Exception e) \{ \} e. printStackTrace () ; \}

@ AmIInteractionMethod

public void response (String name, ArrayList $<$ LCCArgument $>$ args $)\{$

for (LCCArgument arg : args) \{ \} 


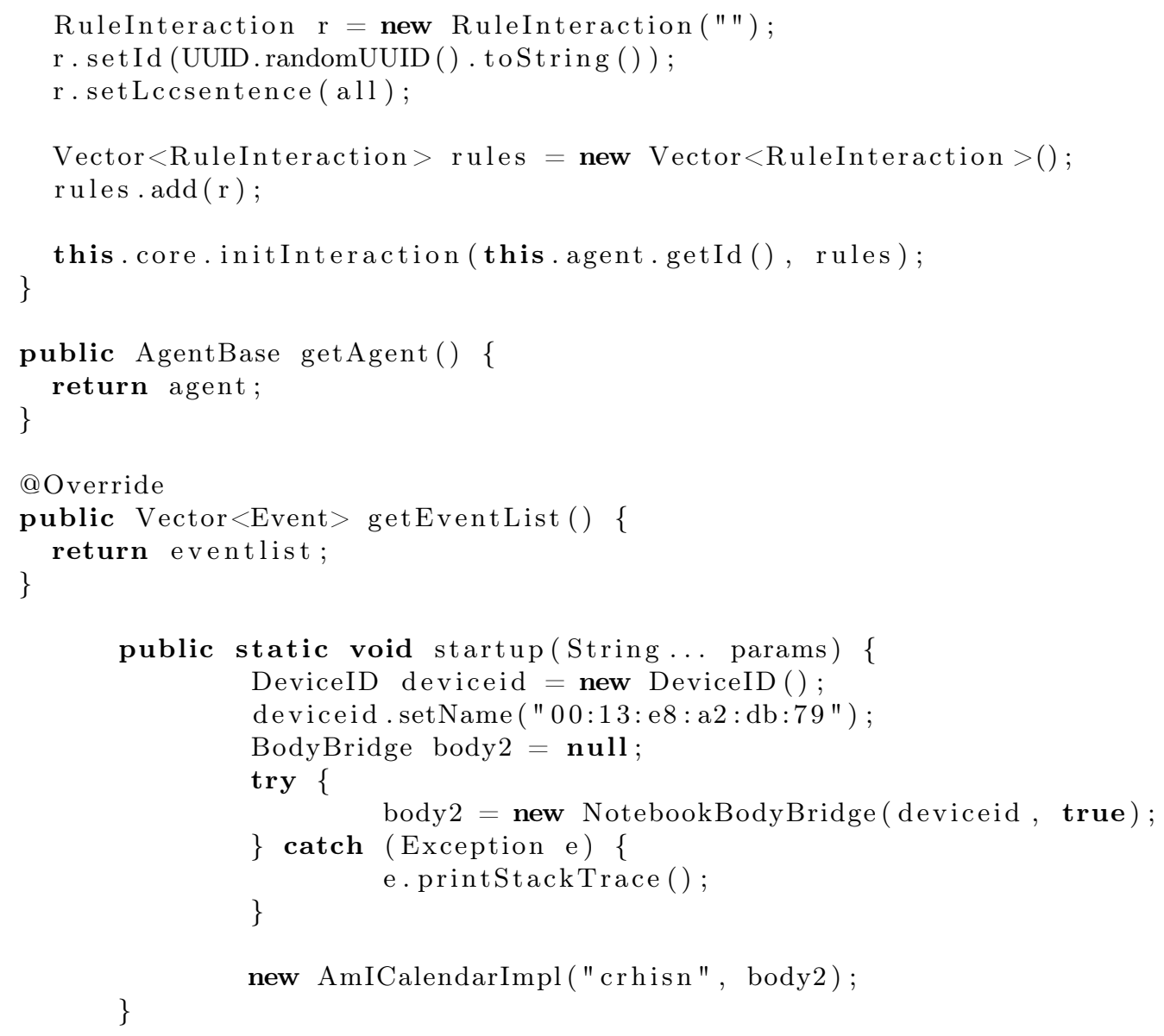

Código A.5: Exemplo de uso da API do ambiente de execução. 
APÊNDICE A 


\section{Apêndice B}

\section{Caso de Estudo: Um ambiente inteligente para o IME}

\section{B.1 Áreas simbólicas do ambiente inteligente do IME}

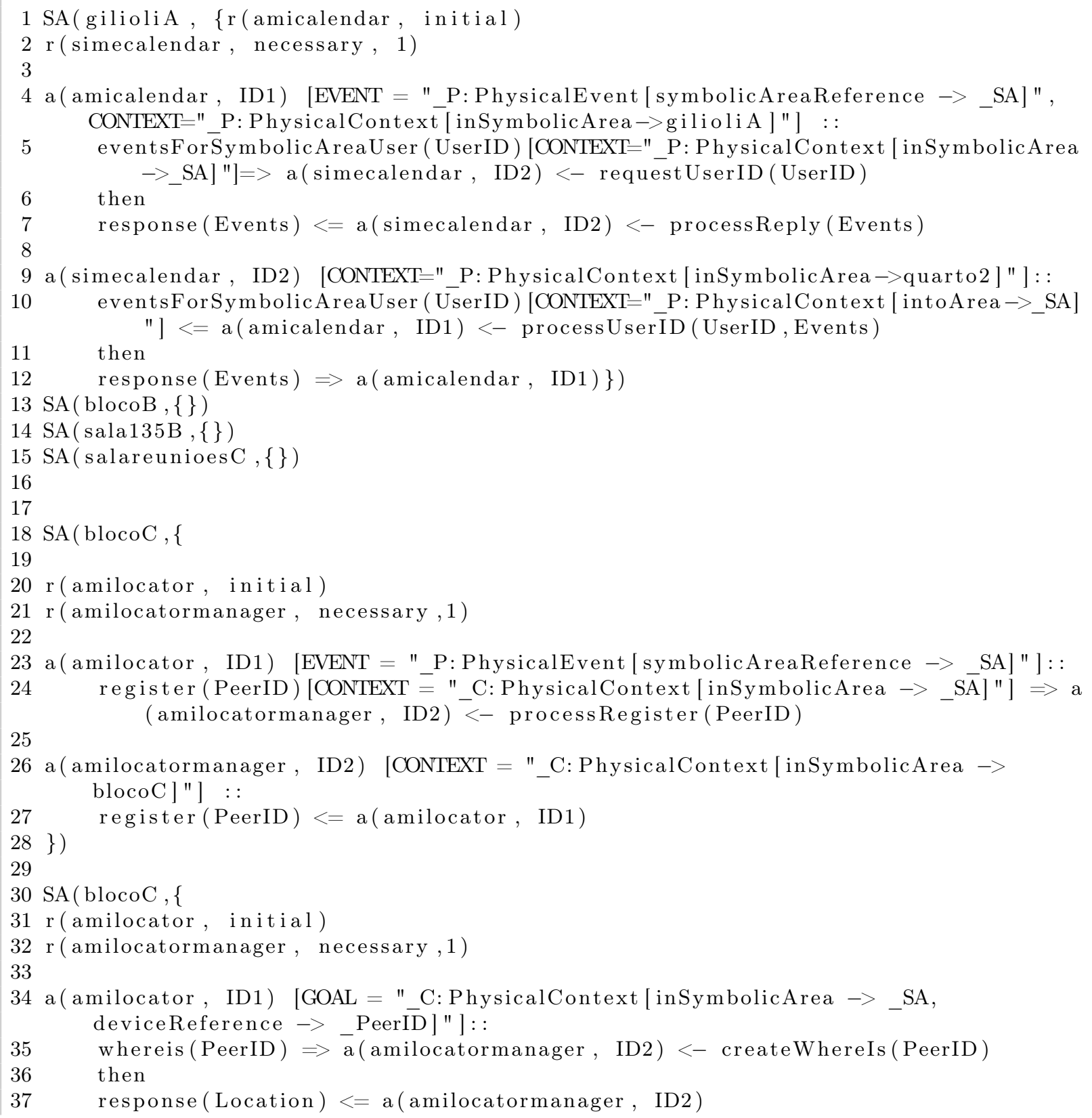


39 a (amilocatormanager, ID2) : :

40 whereis $($ PeerID $)<=$ a (amilocator, ID1) $<-$ processQuery (PeerID, Location)

41 then

42 response(Location $) \Rightarrow$ a(amilocatormanager, ID1) $\})$

43

$44 \mathrm{SA}$ (gilioliA , \{

45 r (speaker, initial)

$46 \mathrm{r}$ (amilocator, necessary, 1 )

47

48 a (speaker, ID1) : :

49 sendPresentation (Presentation) $\Rightarrow$ a(amilocator, ID2) $<-$ preparePresentation ( Presentation)

50

51 a (amilocator, ID2) [EVENT = "_P: PhysicalEvent [symbolicAreaReference $\rightarrow$ gilioliA]" ] : :

52 sendPresentation (Presentation $)<=$ a(speaker, ID1) $\}$ )

53

$54 \mathrm{SA}($ sala $245 \mathrm{~A},\{$

55

56 r (amifileshared, initial)

$57 \mathrm{r}$ (amifileviewer, necessary, 1$)$

58

59 a (amifileshared , ID1) [EVENT = "_P: PhysicalEvent [symbolicAreaReference $\rightarrow$ sala245A ] " ] : :

60 sendFile (PeerID, File, FileProperties $) \Rightarrow$ a (amifileviewer, ID2) $<-$ prepareFile (PeerID, File, FileProperties)

61 then

62 devices (Devices) $<=$ a (amifileviewer, ID2) $<-$ chooseDevice (Device)

63 then

64 showFileInDevice (PeerID, Device) $\Rightarrow$ a (amifileviewer, ID2)

65

66 a (amifileviewer, ID2) [CONTEXT = "_P: PhysicalContext [inSymbolicArea $\rightarrow$ sala245A] " ] : :

67 sendFile (PeerID, File, FileProperties $)<=$ a (amifileshared, ID1)

68 then

69 devices $($ Devices $) \Rightarrow$ a (amifileshared, ID1) $<-$ searchDevices (Devices)

70 then

71 showFileInDevice (PeerID, Device) <= a (amifileshared, ID1) <- showFile $($ PeerID, \}) Device )

73

4 SA (salaETS , \{

75

76 r (amifileshared, initial)

77 r (amiprinter, necessary , 1)

78

79 a (amifileshared, ID1) $\quad$ [EVENT = " P: PhysicalEvent [symbolicAreaReference $\rightarrow>$ salaETS ]"] : :

80 sendFile (PeerID, File, FileProperties) $\Rightarrow$ a (amiprinter, ID2) $<-$ prepareFile ( PeerID, File, FileProperties )

81 then

82 confirm (Status) $<=$ a(amiprinter, ID2)

83

84 a (amiprinter, ID2) [CONTEXT = "_P: PhysicalContext [inSymbolicArea $\rightarrow>$ salaETS ] " ]: :

85 sendFile (PeerID, File, FileProperties) <= a (amifileshared, ID1) <- printFile (

PeerID, File, FileProperties, Status)

87 confirm (Status) $\Rightarrow$ a( amifileshared, ID1)

$88\})$

89

$90 \mathrm{SA}$ (blocoB , \{

91

92 r (amifileshared, initial)

93 r (amiprinter, necessary , 1) 


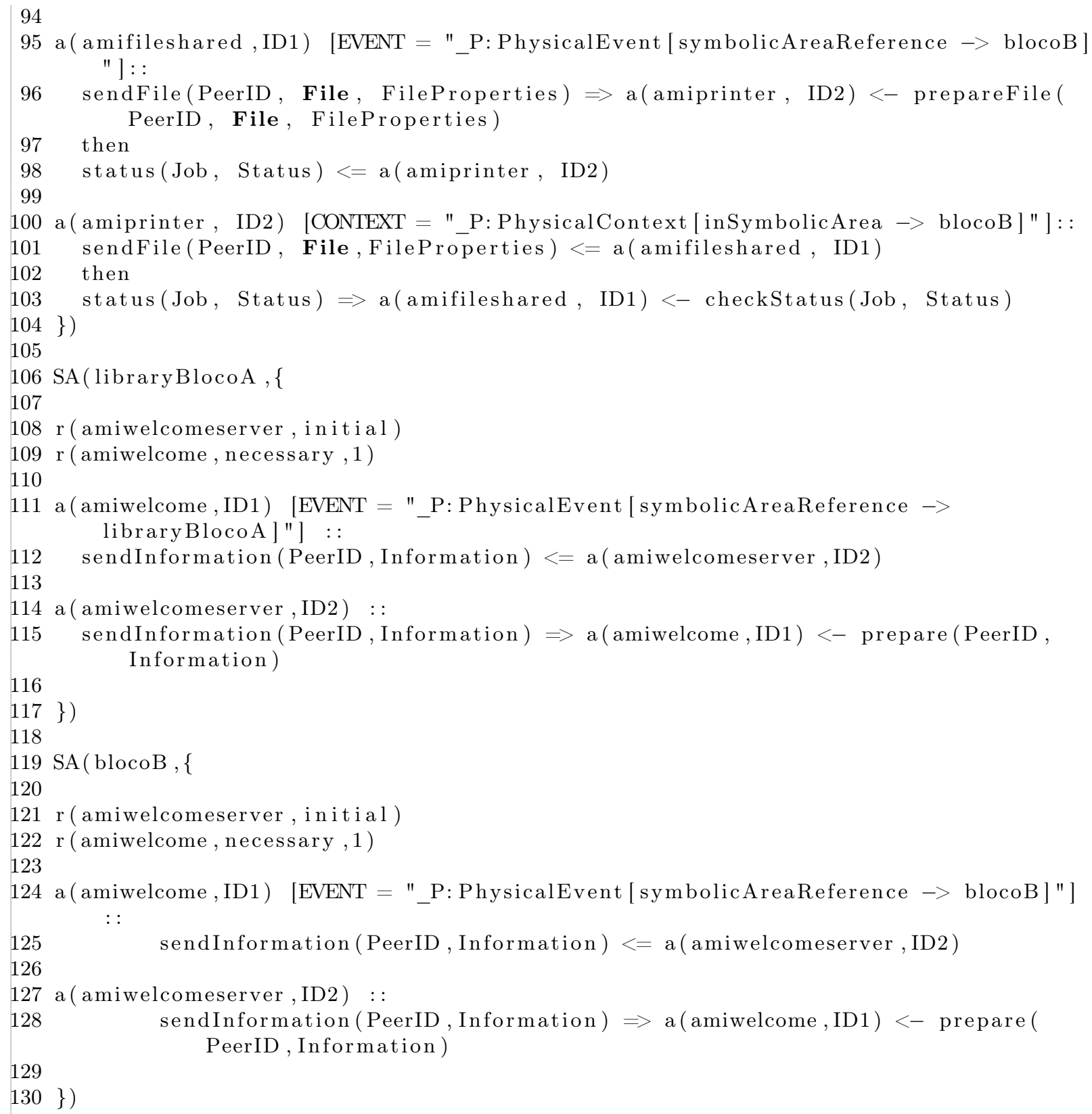

Código B.1: Definição de áreas simbólicas do IME.

\section{B.2 Ontologia da linguagem de especificação}

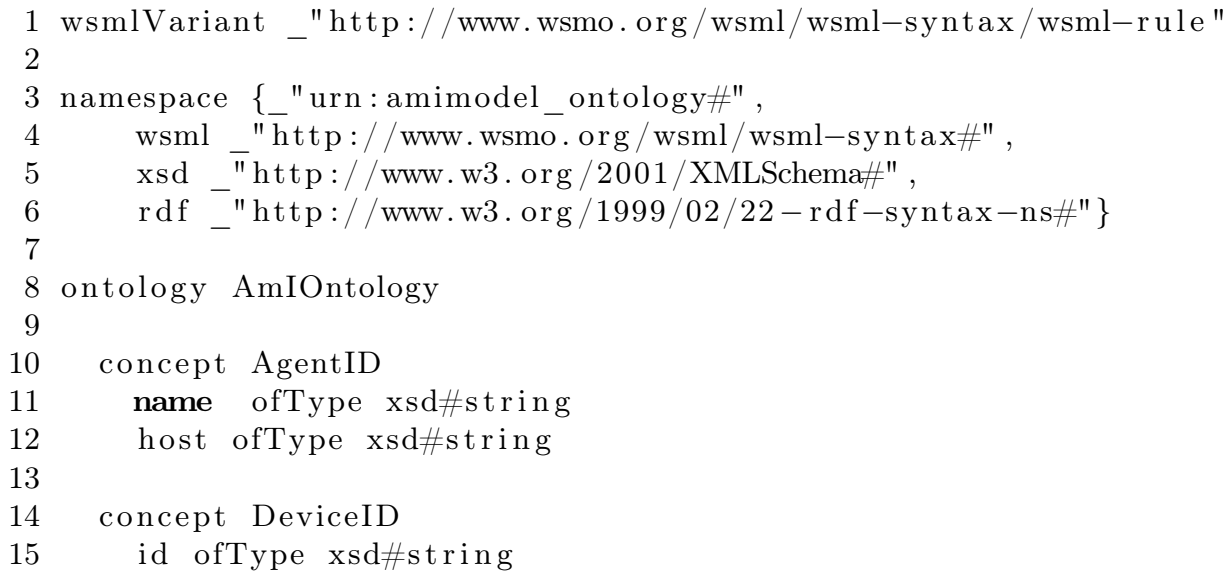




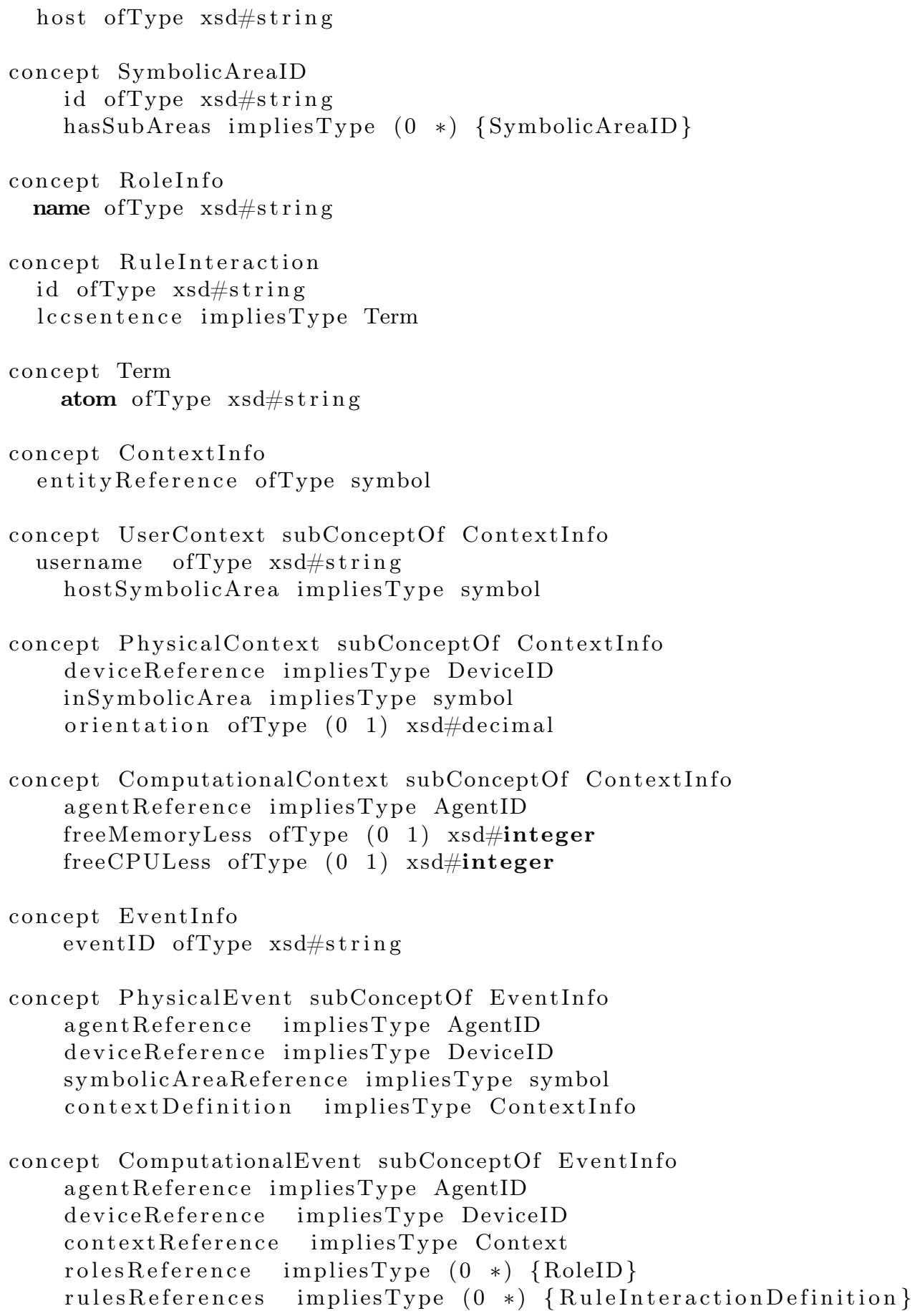




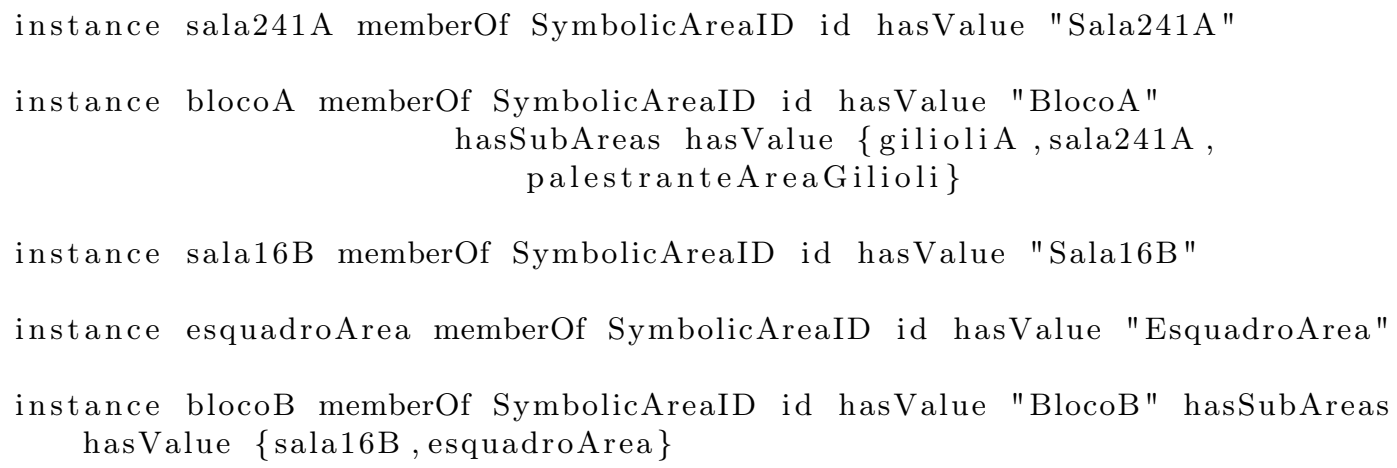

Código B.2: Ontologia da linguagem de especificação.

\section{B.3 Especificação do agente AmlıME}

AgentSpeak é uma linguagem de programação orientada a agentes baseada no modelo BDI (Belief-Desire-Intention) para agentes autônomos. Jason é uma plataforma para execução e interpretação de AgentSpeak.

Além dos planos descritos na Subseção 5.3.7, os planos das linhas 28 e 40 permitem adotar os papeis amiwelcome e amilocator, respectivamente, quando as crenças have_events e who_is_here são adicionadas na base de conhecimento do agente. Desta maneira o agente consegue adotar os papeis adequados de maneira autônoma segundo seu conjunto de crenças.

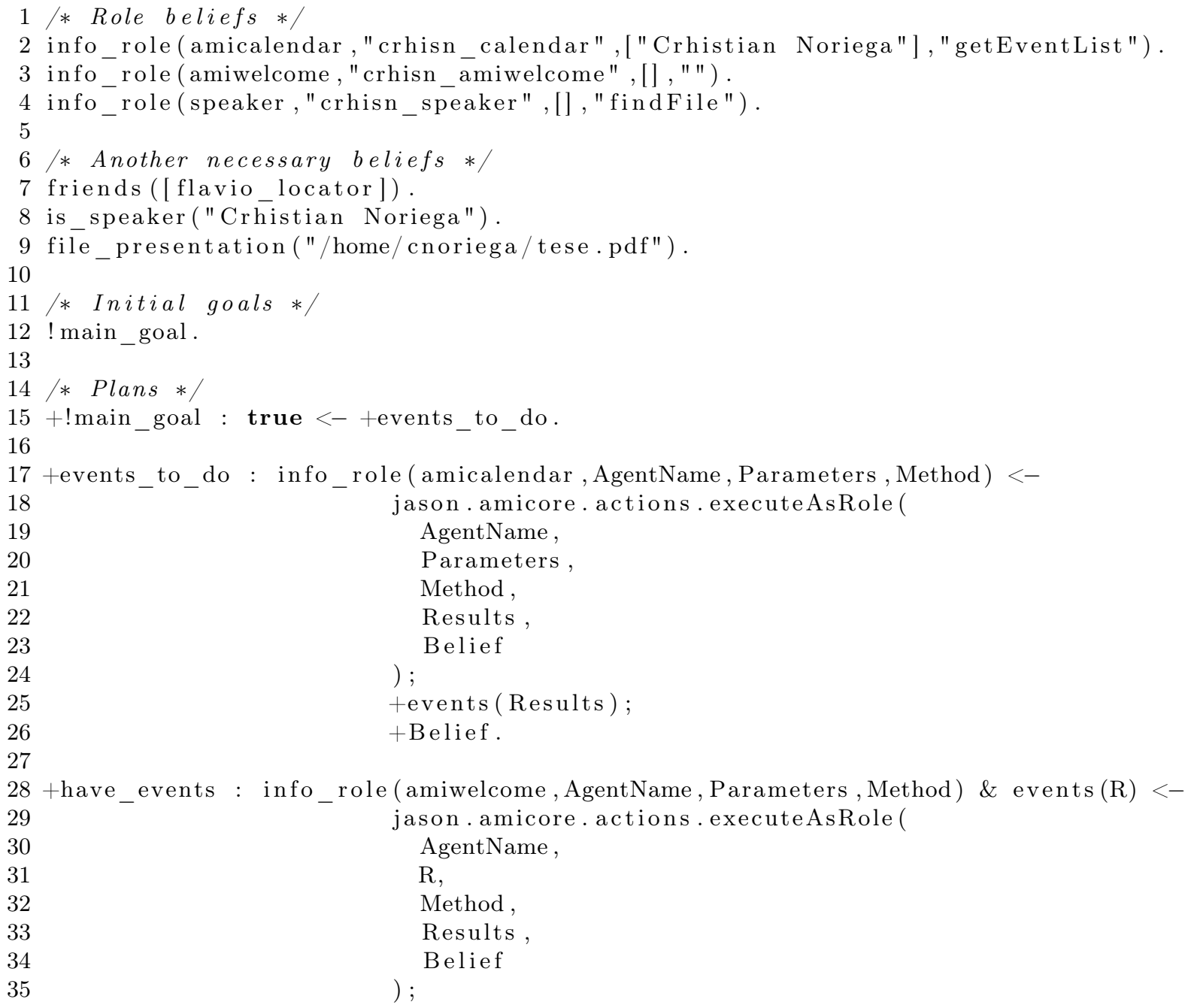




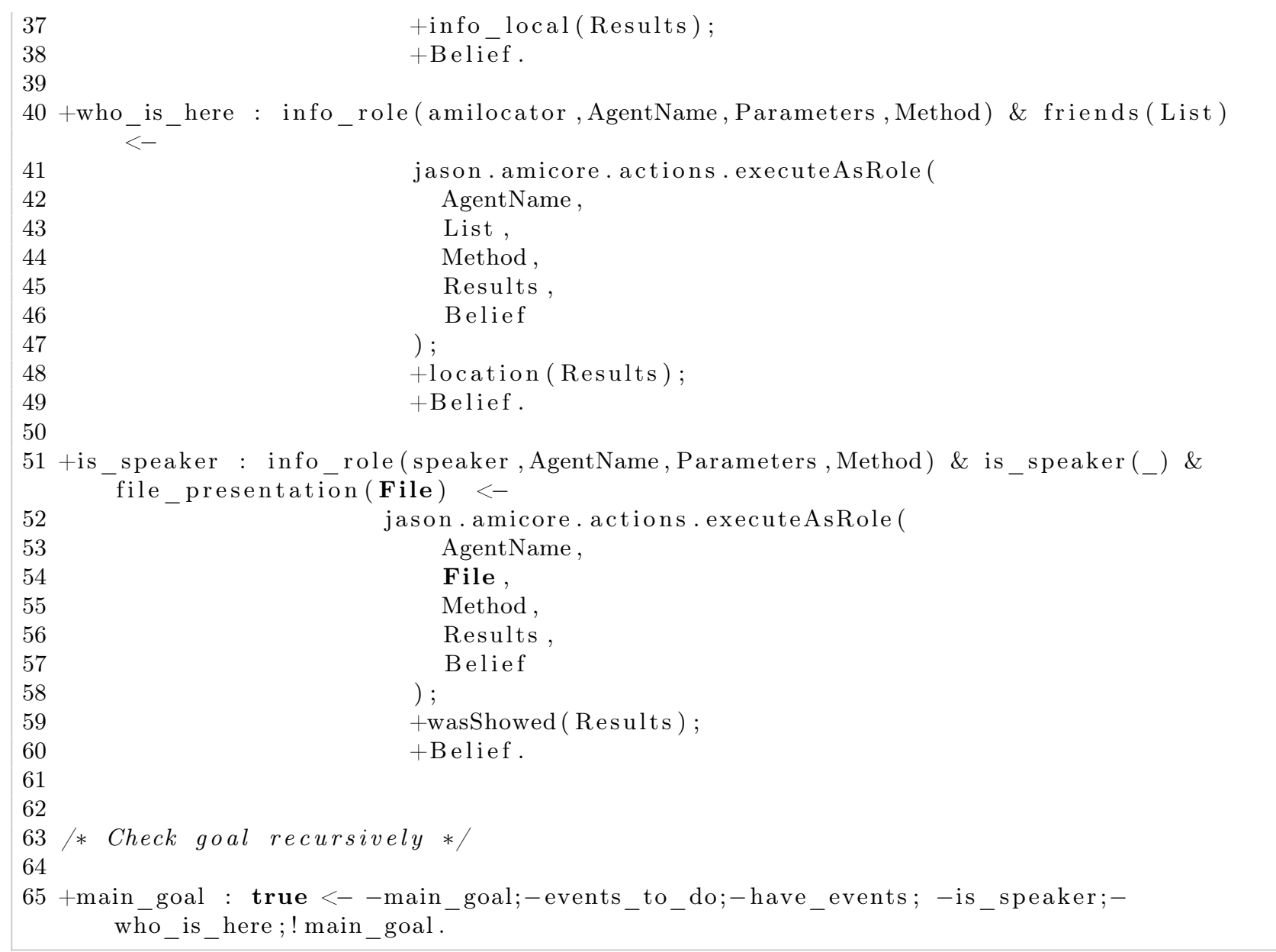

Código B.3: Comportamento do agente AmIIME em AgentSpeak

A classe executeAsRole implementa a ação interna do Jason para ser usada nas definições de planos em AgentSpeak. Esta classe recebe no parâmetro Term[] args do método execute (linha 20) os atributos descritos na Subseção 5.3.7. A lina 23 cria um objeto da classe AmlIME que é um handler para interações e tem também a lógica do agente para criar a crença como resultado da interação.

A classe WaitMessageCallback da linha 27 (apresentada com detalhe no Código B.5) cria em uma thread separada o componente AgentBase segundo os parâmetros das linhas 24 e 25. O método hold trava a execução até obter um resultado da interação.

Finalmente, o resultado da interação e a crença do agente são unificados com os respectivos atributos (Results e Belief da chamada da ação executeAsRole) nas linhas 33 e 37 para serem disponibilizados no entorno do Jason.

A classe AmIIME se encontra disponível em http://code.google.com/p/amimodel/source/browse/ com o projeto em Eclipse de nome AmIIME.

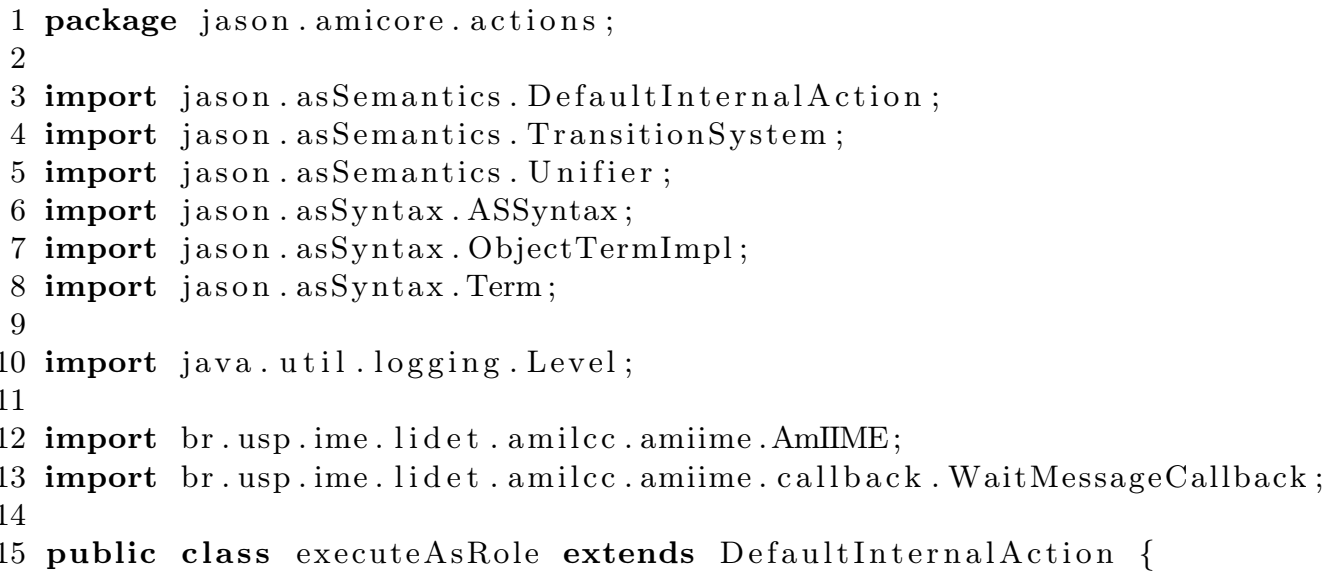




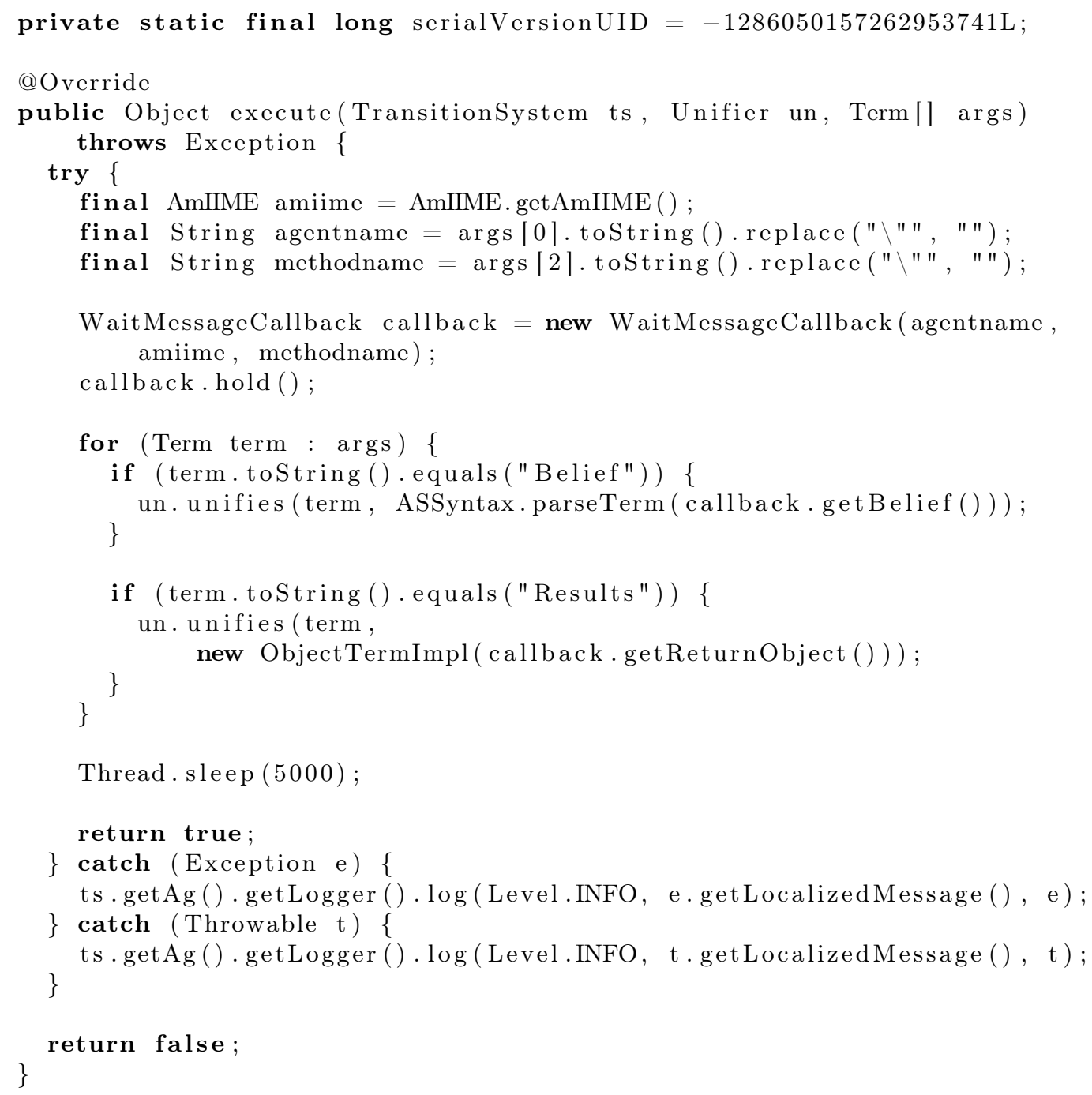

Código B.4: Implementação da ação interna executeAsRole.

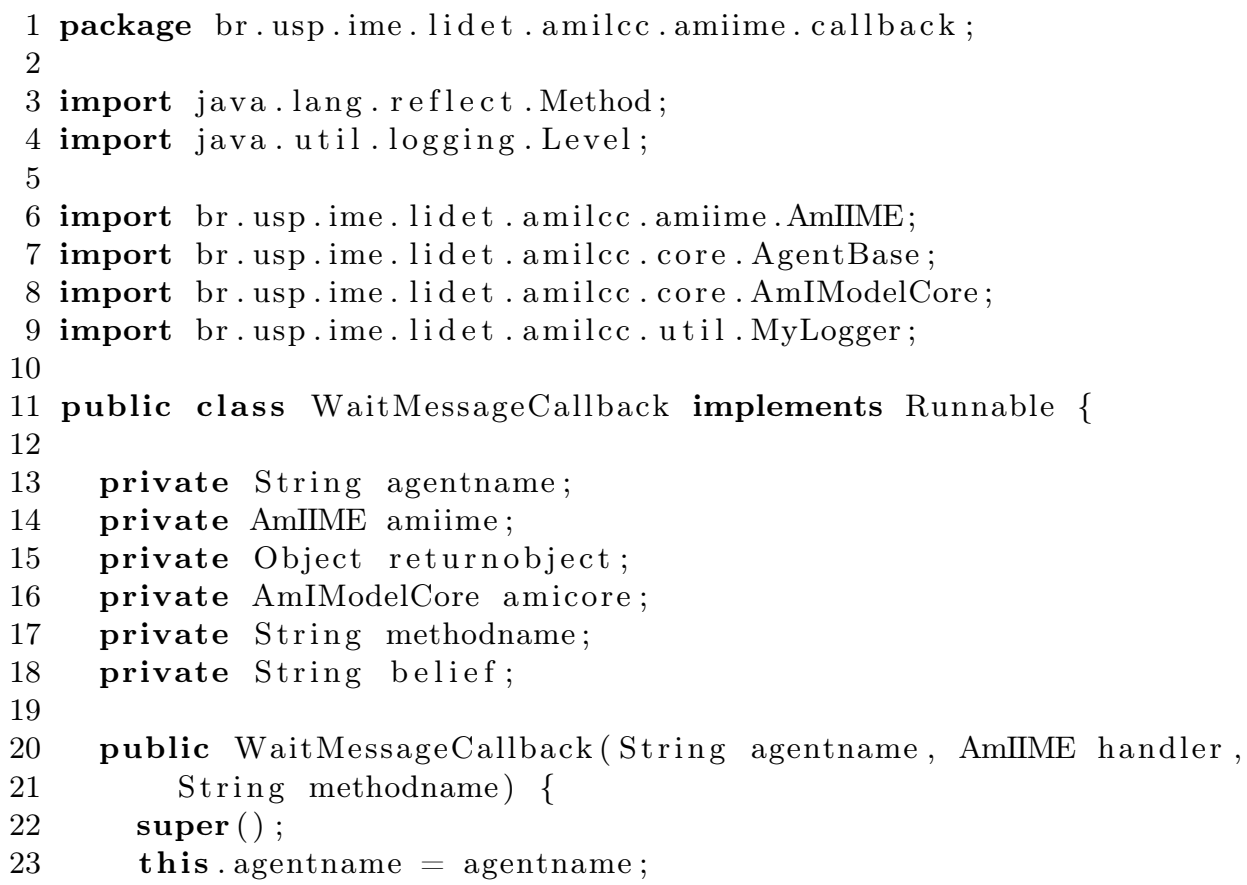


this . amiime $=$ handler;

this . methodname $=$ methodname;

this.amicore = AmIIME. getAmICore ();

this . returnobject $=$ null;

Thread $\mathrm{t}=$ new Thread (this);

\}

t. start ();

public void $\operatorname{run}()\{$

try \{

AgentBase agentbase $=$ this . amicore

. createAgentBaseFromDeclaration (this . agentname);

this . amiime. set Agent (agentbase);

agentbase. setAutoStartInteraction (true);

agentbase.register MessageHandler (this . amiime);

\} catch (Exception e) \{

\}

MyLogger. logger.log (Level.INFO, e.getLocalizedMessage (), e);

\}

public void hold () \{

do \{

try \{

MyLogger. logger.info ("checking");

Method methodreturn $=$ amiime.getClass ()$\cdot \operatorname{get}$ Method (

this.methodname, new Class [] \{\}$)$;

this.returnobject $=$ methodreturn. invoke(this . amiime, new Object []\{\}$)$;

$/ /$ this.returnobject $=$ this.amiime.getEventList();

Thread.sleep (5000);

\} catch (Exception e) \{

MyLogger.logger.log (Level.INFO, e.getLocalizedMessage ()， e ); \}

\} while (this.returnobject $=$ null);

\}

MyLogger. logger.info(this.returnobject.toString ());

public Object getReturnObject() \{

return returnobject;

public String getBelief() \{

return this.amiime. getBelief ();

\}

$70\}$

Código B.5: Criação de componentes AgentBase desde AgentSpeak. 


\section{Referências Bibliográficas}

[AG11] Emile Aarts e Frits Grotenhuis. Ambient intelligence 2.0: Towards synergetic prosperity. J. Ambient Intell. Smart Environ., 3(1):3-11, Janeiro 2011. 82

[AKA09] C. Wu A. Khalili e H. Aghajan. Autonomous learning of user's preference of music and light services in smart home applications. Em Proceedings in Behavior Monitoring and Interpretation Workshop at German AI Conf, 2009. 16

[ANRAS07] Josep Lluis Arcos, Pablo Noriega, Juan A. Rodríguez-Aguilar e Carles Sierra. E4Mas through Electronic Institutions., páginas 184-202. Number 4389. Springer, Berlin / Heidelberg, 08/05/2006 2007. 29, 34

[BCG07] Fabio Luigi Bellifemine, Giovanni Caire e Dominic Greenwood. Developing MultiAgent Systems with JADE. Wiley, 2007. 28, 33, 50, 60

[BHW07] Rafael H. Bordini, Jomi F. Hübner e Michael J. Wooldridge. Programming MultiAgent Systems in AgentSpeak using Jason. John Wiley \& Sons, Ltd, Outubro 2007. Hardcover. 33, 59, 80

$\left[\mathrm{BKR}^{+} 10\right]$ Maribeth Back, Don Kimber, Eleanor Rieffel, Anthony Dunnigan, Bee Liew, Sagar Gattepally, Jonathan Foote, Jun Shingu e James Vaughan. The virtual chocolate factory: mixed reality industrial collaboration and control. Em Proceedings of the international conference on Multimedia, MM '10, páginas 1505-1506, New York, NY, USA, 2010. ACM. 11

[BvdTV06] G. Boella, L. van der Torre e H. Verhagen. Introduction to normative multiagent systems. Computation and Mathematical Organizational Theory, Special issue on Normative Multiagent Systems, 12(2-3):71-79, 2006. 24

[CB03] Paul Couderc e Michel Banatre. Ambient computing applications: an experience with the spread approach. Hawaii International Conference on System Sciences, 9:291, 2003. 33

[Cen] Nokia Research Center. Projeto mara - mobile augmented reality applications. http://research.nokia.com/research/projects/mara/. Último acesso em 01/02/2011. 83

$\left[\mathrm{CGL}^{+}\right.$01] Paul Chou, Marco Gruteser, Jennifer Lai, Anthony Levas, Scott Mcfaddin, Claudio Pinhanez, Marisa Viveros, Danny Wong e Sachiko Yoshihama. Bluespace: Creating a personalized and context-aware workspace. Relatório técnico, IBM Research, 2001. 12

[Che04] Harry Lik Chen. An Intelligent Broker Architecture for Pervasive Context-Aware Systems. Tese de Doutorado, University of Maryland, 2004. 20, 28, 52

[Cis11] Cisco. Cisco visual networking index: Global mobile data traffic forecast update, 2010-2015, February 2011. http://www.cisco.com/en/US/solutions/collateral/ ns341/ns525/ns537/ns705/ns827/white_paper_c11-520862.pdf. 1, 23 
[CN10] Liming Chen e Chris Nugent. Situation aware cognitive assistance in smart homes. Journal of Mobile Multimedia, 6(3):263-280, Setembro 2010. 16

[cog] Cogknow: helping people with mild dementia navigate their day. http://www. cogknow.eu/. Último acesso em 01/02/2011. 17

[CUWA11] Chih-Wei Chen, Rodrigo Cilla Ugarte, Chen Wu e Hamid Aghajan. Discovering social interactions in real work environments. Em IEEE International Conference on Automatic Face and Gesture Recognition, páginas 933-938, Santa Barbara, CA, March 2011. 16, 23, 24

[dad] Daden limited, birmingham, uk. http://www.daden.co.uk/. Último acesso em 01/02/2011. 83

$\left[\mathrm{DBS}^{+}\right.$01] K. Ducatel, M. Bogdanowicz, F. Scapolo, J. Leijten e J. C. Burgelman. Scenarios for ambient intelligence in 2010. Relatório técnico, IST Advisory Group, Fevereiro 2001. $1,7,84$

[DJ06] Paul Davidsson e Stefan Johansson. On the potential of norm-governed behavior in different categories of artificial societies. Computational Mathematical Organization Theory, 12(2-3):169-180, Outubro 2006. 3, 25, 26

[DL95] K. Decker e V. Lesser. Designing a Family of Coordination Algorithms. Proceedings of the First International Conference on Multi-Agent Systems (ICMAS-95), páginas 73-80, January 1995. 20, 24, 52

$\left[\mathrm{DNM}^{+} 10\right]$ Mark Donnelly, Chris Nugent, Sally McClean, Bryan Scotney, Sarah Mason, Peter Passmore e David Craig. A mobile multimedia technology to aid those with alzheimer's disease. IEEE Multimedia, 17:42-51, 2010. 17

[dSV07] Flavio Soares Correa da Silva e Wamberto Weber Vasconcelos. Managing responsive environments with software agents. Appl. Artif. Intell., 21(4-5):469-488, Abril 2007. 1

[Edm06] Bruce Edmonds. How are physical and social spaces related? - Cognitive agents as the necessary glue. Springer, 2006. 23

[eRC08] Luciano Baresi e Roberto Cascella. Bringing autonomic services to life. Relatório técnico, Component-ware for Autonomic Situation-aware Communications, and Dynamically Adaptable Services, 2008. 17

[Est03] Marc Esteva. Electronic institutions. from specification to development. Tese de Doutorado, Universitat Politecnica de Catalunya, 2003. 3, 29, 42

[FGM03] Jacques Ferber, Olivier Gutknecht e Fabien Michel. From agents to organizations: An organizational view of multi-agent systems. Em Paolo Giorgini, Jörg P. Müller e James Odell, editors, AOSE, volume 2935 of Lecture Notes in Computer Science, páginas 214-230. Springer, 2003. 25

[FVDRGS+10] Ana Fernández Vilas, Rebeca P. Díaz Redondo, Alberto Gil Solla, Manuel Ramos Cabrer, José J. Pazos Arias e Jorge García Duque. An AmI-enabled OSGi platform based on socio-semantic technologies, volume Smart Home Systems, chapter 5, páginas 85-104. InTech Education and Publishing, 2010. 1, 2, 13

[Gag05] A Gaggioli. Optimal experience in ambient intelligence. Ambient Intelligence, páginas 35-43, 2005. 20, 29, 74, 84 
[GC03] Andrew D. Gordon e Luca Cardelli. Equational properties of mobile ambients. Mathematical Structures in Computer Science, 13(3):371-408, 2003. 2

[GC09] Andrés García-Camino. Normative Regulation of Multi-agent Systems. Tese de Doutorado, Universitat Autónoma de Barcelona, 2009. 3, 25, 29, 34

[GHAH10] Manuel García-Herranz, Xavier Alamán e Pablo A. Haya. Easing the smart home: A rule-based language and multi-agent structure for end user development in intelligent environments. JAISE, 2(4):437-438, 2010. 1

[goo] Google earth. http://earth.google.com/. Último acesso em 01/02/2011. 83

[GS08] Crhistian Alberto Noriega Guerra e Flavio Soares Correa da Silva. Semantic web services for smart environments. Em Proceedings of the 2008 11th IEEE International Conference on Computational Science and Engineering - Workshops, CSEWORKSHOPS '08, páginas 281-287, Washington, DC, USA, 2008. IEEE Computer Society. 1

[HAK08] Chen Wu Hamid Aghajan e Richard Kleihorst. Distributed Vision Networks for Human Pose Analysis. Springer, 2008. 16

[HK04] M Hellenschmidt e T Kirste. Sodapop: a software infrastructure supporting selforganization in intelligent environments. 2nd IEEE International Conference on Industrial Informatics 2004 INDIN 04 2004, páginas 479-486, 2004. 14

[HMEZ ${ }^{+}$05] S. Helal, W. Mann, H. El-Zabadani, J. King, Y. Kaddoura e E. Jansen. The gator tech smart house: a programmable pervasive space. Computer, 38(3):50-60, Março 2005. 1, 2, 18

[HMSK11] Seth Hunter, Pattie Maes, Stacey Scott e Henry Kaufman. Memtable: an integrated system for capture and recall of shared histories in group workspaces. Em Proceedings of the SIGCHI Conference on Human Factors in Computing Systems, CHI '11, páginas 3305-3314, New York, NY, USA, 2011. ACM. 10, 27

[IST ${ }^{+}$05] Valérie Issarny, Daniele Sacchetti, Ferda Tartanoglu, Françoise Sailhan, Rafik Chibout, Nicole Lévy e Angel Talamona. Developing Ambient Intelligence Systems: A Solution based on Web Services. Automated Software Engineering, 12(1):101-137, 2005. 51

[JAL10] Benjamin Salem e Matthias Rauterberg Jorge Alves Lino. Responsive environments: User experiences for ambient intelligence. Em Journal of Ambient Intelligence and Smart Environments. IOS Press Amsterdam, 2010. 1

[JdPBR ${ }^{+}$07] Sindhu Joseph, Adrián Perreau de Pinninck Bas, David Robertson, Carles Sierra e Chris Walton. Interaction model language definition. páginas 49-61, 2007. 3, 29, 42

[JSW98] Nicholas R. Jennings, Katia Sycara e Michael Wooldridge. A roadmap of agent research and development. Autonomous Agents and Multi-Agent Systems, 1(1):738, Janeiro 1998. 25, 28

[KLW95] Michael Kifer, Georg Lausen e James Wu. Logical foundations of object-oriented and frame-based languages. JOURNAL OF THE ACM, 42:741-843, 1995. 42, 46

[KMTT03] Naohiko Kohtake, Kenta Matsumiya, Kazunori Takashio e Hideyuki Tokuda. Smart device collaboration for ubiquitous computing environment. Em In Proceedings of the Workshop on Multi-Device Interface for Ubiquitous Peripheral Interaction at the 5th International Conference on Ubiquitous Computing (UbiComp'03, 2003. 19 
$\left[\mathrm{KOA}^{+} 99\right]$ Cory D. Kidd, Robert Orr, Gregory D. Abowd, Christopher G. Atkeson, Irfan A. Essa, Blair MacIntyre, Elizabeth D. Mynatt, Thad Starner e Wendy Newstetter. The aware home: A living laboratory for ubiquitous computing research. Em Proceedings of the Second International Workshop on Cooperative Buildings, Integrating Information, Organization, and Architecture, CoBuild '99, páginas 191-198, London, UK, UK, 1999. Springer-Verlag. 20

[KWA10] A. H. Khalili, Chen Wu e H. Aghajan. Hierarchical preference learning for light control from user feedback. páginas 56-62, Junho 2010. 15

$\left[\mathrm{LET}^{+}\right.$09] Myriam Lipprandt, Marco Eichelberg, Wolfgang Thronicke, Jan Kruger, Isabell Druke, Detlev Willemsen, Clemens Busch, Christoph Fiehe, Elmar Zeeb e Andreas Hein. Osami-d: An open service platform for healthcare monitoring applications. Em Proceedings of the IEEE 2nd Conference on Human System Interactions (HSI 2009), páginas 139-145, Catania, Italy, 2009. IEEE Computer Society. 14

[LM10] Natan Linder e Pattie Maes. Luminar: portable robotic augmented reality interface design and prototype. Em Adjunct proceedings of the 23nd annual ACM symposium on User interface software and technology, UIST '10, páginas 395-396, New York, NY, USA, 2010. ACM. 9

[mic] Microsoft maps. http://maps.live.com/. Último acesso em 01/02/2011. 83

[MM09a] Pranav Mistry e Pattie Maes. Augmenting sticky notes as an i/o interface. Em Constantine Stephanidis, editor, HCI (6), volume 5615 of Lecture Notes in Computer Science, páginas 547-556. Springer, 2009. 9

[MM09b] Pranav Mistry e Pattie Maes. Sixthsense: a wearable gestural interface. Em $A C M$ SIGGRAPH ASIA 2009 Sketches, SIGGRAPH ASIA '09, páginas 11:1-11:1, New York, NY, USA, 2009. ACM. 9, 27

$\left[\mathrm{MYA}^{+}\right.$05] Jianhua Ma, Laurence Tianruo Yang, Bernady O. Apduhan, Runhe Huang, Leonard Barolli e Makoto Takizawa. Towards a smart world and ubiquitous intelligence: A walkthrough from smart things to smart hyperspaces and ubickids. Int. J. Pervasive Computing and Communications, 1(1):53-68, 2005. 23

[Nak09] Hamid; Augusto e Juan Carlos Nakashima, Hideyuki; Aghajan. Handbook of Ambient Intelligence and Smart Environments. Springer, $1^{\circ}$ edição, 2009. 1, 7, 19

[Nor07] Crhistian Noriega. Um modelo para ambientes inteligentes baseado em servicos web semanticos. Dissertação de Mestrado, Instituto de Matemática e Estatística, Universidade de São Paulo, Brasil, Agosto 2007. 1, 10, 20, 24, 52, 60

$\left[\mathrm{NSN}^{+}\right.$02] Mark W. Newman, Jana Z. Sedivy, Christine M. Neuwirth, W. Keith Edwards, Jason I. Hong, Shahram Izadi, Karen Marcelo e Trevor F. Smith. Designing for serendipity: supporting end-user configuration of ubiquitous computing environments. Em Proceedings of the 4th conference on Designing interactive systems: processes, practices, methods, and techniques, DIS '02, páginas 147-156, New York, NY, USA, 2002. ACM. 1

[ope] Projeto openknowledge. http://www.openk.org. Último acesso em 01/02/2011. 20, $30,42,52$

[OZKT01] Andrea Omicini, Franco Zambonelli, Matthias Klusch e Robert Tolksdorf, editors. Coordination of Internet Agents: Models, Technologies, and Applications. Springer, 2001. 2, 24, 33 
[per10] Final Reference Architecture model for AAL and recommendations for future activities on the Open AAL platform. Relatório técnico, AALIANCE initiative - The European Ambient Assisted Living Innovation Alliance, 2010. 1, 2, 3, 14

[Pin01] Claudio Pinhanez. Augmenting reality with projected interactive displays. Em Proceedings of International Symposium on Virtual and Augmented Architecture VAA, 2001. 12

[PLFN11] G. Pfurtscheller, R. Leeb, J. Faller e C. Neuper. Virtual Reality, chapter BrainComputer Interface Systems Used for Virtual Reality Control. InTech, 2011. 17, 27

[PMR99] Gian Pietro Picco, Amy L. Murphy e Gruia-Catalin Roman. Lime: Linda meets mobility. Em Proceedings of the 21st international conference on Software engineering, ICSE '99, páginas 368-377, New York, NY, USA, 1999. ACM. 2, 33

[RA04] Jörg Rech e Klaus-Dieter Althoff. Artificial intelligence and software engineering: Status and future trends. KI, 18(3):5-11, 2004. 81

[RBB03] Fano Ramparany, Olivier Boissier e Henri Brouchoud. Cooperating autonomous smart devices. Em 1st Smart Object Conference, 2003. 1

$\left[\mathrm{RHC}^{+}\right.$02] Manuel Román, Christopher Hess, Renato Cerqueira, Roy H. Campbell e Klara Nahrstedt. Gaia: A middleware infrastructure to enable Active Spaces. IEEE Pervasive Computing, 1:74-83, 2002. 2, 23

[RKV10] Eleanor G. Rieffel, Don Kimber e Jim Vaughan. Geometric reconstruction from point-normal data. CoRR, abs/1003.3499, 2010. 11

[Ros09] Keogh E Eccleston C Mountain G Rosser, B. Smart2: Development towards a technology-based system for self-management of chronic pain. Em nternational Association for the Study of Pain, 13th World Congress on Pain, Montreal, 2009. 17

$\left[\right.$ RVD $\left.^{+} 05\right]$ G. Riva, F. Vatalaro, F. Davide, M. Alcañiz Eds e Albrecht Schmidt. Interactive Context-Aware systems interacting with ambient intelligence. 2005. 4, 33, 84

[SA07] Sandip Sen e Stephane Airiau. Emergence of norms through social learning. Em Proceedings of the Twentieth International Joint Conference on Artificial Intelligence (IJCAI'07), páginas 1507-1513, Cambridge, MA, 2007. MIT Press. 23

[seca] Second earth. https://www.technologyreview.com/Infotech/18888/. Último acesso em $01 / 02 / 2011.83$

[secb] Second life. http://secondlife.com/. Último acesso em 01/02/2011. 83

[SER ${ }^{+}$04] Vagner Sacramento, Markus Endler, Hana K. Rubinsztejn, Luciana S. Lima, Kleder Gonçalves, Fernando N. Nascimento e Giulliano A. Bueno. Moca: A middleware for developing collaborative applications for mobile users. IEEE Distributed Systems Online, 5, 2004. 28, 38, 51, 52

[SG02] João Pedro Sousa e David Garlan. Aura: an architectural framework for user mobility in ubiquitous computing environments. Em Proceedings of the IFIP 17th World Computer Congress - TC2 Stream / 3rd IEEE/IFIP Conference on Software Architecture: System Design, Development and Maintenance, WICSA 3, páginas 29-43, Deventer, The Netherlands, The Netherlands, 2002. Kluwer, B.V. 2, 74 
[SIK04] Akio Sashima, Noriaki Izumi e Koichi Kurumatani. Bridging coordination gaps between devices, services, and humans in ubiquitous computing. Em Workshop on Agents for Ubiquitous Computing - UbiAgents, 2004. 35

[SM] Computer Science e Artificial Intelligence Laboratory MIT. Projecto oxygen - pervasive, human-centered computing. http://www.oxygen.lcs.mit.edu. Último acesso em $01 / 02 / 2011.2$

[ST92] Yoav Shoham e Moshe Tennenholtz. On the synthesis of useful social laws for artificial agent societies. Em Proceedings of the tenth national conference on Artificial intelligence, AAAI'92, páginas 276-281. AAAI Press, 1992. 24

[STCDS $\left.{ }^{+} 08\right]$ G. Salazar-Torres, E. Colombo, F.S. Correa Da Silva, C. A. Noriega e S. Bandini. Design issues for knowledge artifacts. Know.-Based Syst., 21(8):856-867, Dezembro 2008. 49

[TKA06] Ali Maleki Tabar, Arezou Keshavarz e Hamid Aghajan. Smart home care network using sensor fusion and distributed vision-based reasoning. Em Proceedings of the 4th ACM international workshop on Video surveillance and sensor networks, VSSN '06, páginas 145-154, New York, NY, USA, 2006. ACM. 2, 3, 16, 21

[TQB $\left.{ }^{+} 10\right]$ Thea Turner, Pernilla Qvarfordt, Jacob T. Biehl, Gene Golovchinsky e Maribeth Back. Exploring the workplace communication ecology. Em Proceedings of the 28th international conference on Human factors in computing systems, CHI '10, páginas 841-850, New York, NY, USA, 2010. ACM. 11

[vD09] M. G. L. M. van Doorn. End-User Programming Of Ambient Narratives For Smart Retail Environments. Tese de Doutorado, TU Eindhoven, 2009. 8

[VDRPA $^{+}$10] Ana Fernandez Vilas, Rebeca P. Diaz Redondo, Jose J. Pazos Arias, Manuel Ramos Cabrer, Alberto Gil Solla e Jorge Garcia Duque. Context-aware personalization services for a residential gateway based on the osgi platform. Expert Syst Appl, 37(9):6538-6546, Setembro 2010. 13

[Ver00] H.J.E. Verhagen. Norm Autonomous Agents. Tese de Doutorado, Royal Institute of Technology and Stockholm University, 2000. 3, 24, 25

[Viz04] Giuseppe Vizzari. Dynamic Interaction Spaces and Situated Multi-Agent Systems: from a Multi-Layered Model to a Distributed Architecture. Tese de Doutorado, Universita degli Studi di Milano-Bicocca, 2004. 3

[VRV05] Mathieu Vallée, Fano Ramparany e Laurent Vercouter. Flexible composition of smart device services. Em In: The 2005 International Conference on Pervasive Systems and Computing(PSC-05), Las Vegas, páginas 27-30, 2005. 14

[WA09] Chen Wu e Hamid Aghajan. Using context with statistical relational models: object recognition from observing user activity in home environment. Em Proceedings of the Workshop on Use of Context in Vision Processing, UCVP '09, páginas 5:1-5:6, New York, NY, USA, 2009. ACM. 4, 15, 20, 29

[WG00] Zhenyu Wang e David Garlan. Task-driven computing. Relatório técnico, School of Computer Science, Carnegie Mellon University, 2000. 2, 83

[WR02] Christopher Walton e David Robertson. Flexible multi-agent protocols. Relatório técnico, University of Edinburgh, 2002. 3, 20, 29, 42, 47 